МIНICТЕРСТВО ОСВІТИ I НАУКИ УКРАЇНИ

ХАРКІВСЬКА ДЕРЖАВНА АКАДЕМІЯ ФІЗИЧНОЇ КУЛЬТУРИ

\title{
СЛОБОЖАНСЬКИЙ НАУКОВО-СПОРТИВНИЙ ВІСНИК
}

\section{Науково-теоретичний журнал}

Виходить 6 разів на рік

Видається з 1997p.

$$
6(74)
$$


Журнал включає статті, в яких відображено матеріали сучасних наукових досліджень у галузі фізичної культури та спорту.

Журнал призначено для викладачів, тренерів, спортсменів, аспірантів, докторантів, наукових працівників та інших фахівців галузі.

Журнал включений до переліку фахових видань України, в яких можуть публікуватися результати дисертаційних робіт, галузь науки - "Фізичне виховання та спорт" (категорія "Б") (Постанова президії ВАК України: № 3-05/11 від 10.11.1999 р., № 1-05/34 від 14.10. 2009 р.; Наказ МОН України № 1081 від 29.09.2014 р.; Наказ МОН України №612 від 07.05.2019).

Друкується за постановою вченої ради ХДАФК (протокол № 20 від 16.12.2019)

Розміщення журналу у наукометричних базах, репозитаріях:

Ulrich's Periodical Directory, WorldCat, DOAJ, ERIH PLUS, SPORTDiscus (EBSCO), OpenAIRE, Sherpa/ Romeo, ROAD, Національна бібліотека України імені В.І.Вернадського, CrossRef, Google Scholar, EZB (Electronic Journals Library), J-Gate (eng.), IndexCopernicus (eng.), Trinity western university (Canada), JournalTOCs, The Open Access Digit Library, Open Science Directory, Stanford University Libraries (USA), AcademicKeys, British Library's Electronic Table of Contents (ETOC), ZDB (Germany), COPAC (UK), SUDOC (France), Lancaster University Library (UK), Open Academic Journals Index, MIAR, BASE, Open Science Directory (EBSCO)

Сайт журналу:

http://journals.uran.ua/index.php/1991-0177

Сайт англомовної версії журналу

"Slobozhanskyi Herald of Science and Sport": http://journals.uran.ua/sport_herald

ISSN (Ukrainian ed. Print) 1991-0177

ISSN (Ukrainian ed. Online) 1999-818X

ISSN (English ed. Online) 2311-6374

Key title: Slobozans ‘kij naukovo-sportivnij visnik

Abbreviated key title: Slobozans`kij nauk.-sport. visn.
() Харківська державна академія фізичної культури, 2019 


\section{СЛОБОЖАНСЬКИЙ НАУКОВО-СПОРТИВНИЙ ВІСНИК}

\section{Головний редактор}

Анатолій Ровний, доктор наук з фізичного виховання і спорту, професор, академік Міжнародно академії проблем людини в авіації та космонавтиці (Харківська державна академія фізичної культури, Україна)

Редакційна колегія:

Олександр Ажиппо, доктор педагогічних наук, професор (Харківська державна академія фізичної культури, Україна)

\section{Володимир Ашанін, кандидат фізико-}

математичних наук, професор, академік АНПРЕ

(Харківська державна академія фізичної культури, Україна)

Евгений Врублевский, доктор педагогических наук, профессор (Гомельский государственный университет имени Франциска Скорины, Беларусь

Валерій Друзь, доктор біологічних наук, професор (Харківська державна академія фізичної культури, Україна)

Олег Камаєв, доктор наук з фізичного виховання і спорту, професор (Харківська державна академія фізичної культури, Україна)

Леся Коробейнікова, доктор біологічних наук професор (Національний університет фізичної культури і спорту України, Україна)

Вячеслав Мулик, доктор наук з фізичного виховання і спорту, професор (Харківська державна академія фізичної культури, Україна)

Леонід Подрігало, доктор медичних наук, професор (Харківська державна академія фізичної культури, Україна)

Євген Приступа, доктор педагогічних наук, професор (Львівський державний університе фізичної культури, Україна)

Wojciech Czarny, Doctor of Science (Physical Culture), Professor (Uniwersytet Rzeszowski, Polska/ Poland)

Людмила Шестерова, кандидат наук з фізичного виховання і спорту, доцент (Комунальний заклад «Харківська гуманітарно-педагогічна академія» Харківської обласної ради, Україна)

Юлія Калмикова, кандидат наук з фізичного виховання і спорту, доцент (Харківська державна академія фізичної культури, Україна)

Mosab Saleem Hamed Amoudi, PhD (Physical Therapy), Arab American university, Jenin, Palestine

Mohammed Zerf, PhD, Physical Education Institut University Abdelhamid Ibn Badis de Mostaganem, Mostaganem, Algeria

\section{MICT}

\section{Лариса Таран}

Особливості діяльності Першого Гімнастичного Товариства у

Харківській губернії наприкінці XIX та початку XX сторічь

Олена Тарасевич, Олег Камаєв, Дар'я Окунь

Гендерна ідентифікація спортсменів різної кваліфікації відносно

класифікаційних груп видів спорту

Катерина Тимрук-Скоропад, Юлія Павлова, Надія Сидорик Стратегія самоменеджменту у навчальних програмах для пацієнтів із хронічним обструктивним захворюванням легень

\section{Маргарита Мамешина}

Диференціація змісту навчальних занять з фізичного виховання з урахуванням показників фізичного здоров'я та фізичної

підготовленості школярів 7-9-х класів

\section{Ярослав Крайник, Вячеслав Мулик, Дар'я Окунь \\ Святослав Коваль}

Використання спеціальних вправ для

розвитку рухових якостей та формування техніко-тактичних

дій захисників 13-14 років у підготовчому періоді

\section{Олена Бісмак}

Алгоритм застосування засобів фізичної терапії в осіб

з компресійно-ішемічними невропатіями верхньої кінцівки

\section{Валерий Друзь, Ярослава Волкова, Алексей Гуляев}

Прогнозирование перспективности в занятиях танцевальными

и гимнастическими видами спорта на основе метода оценки

структуры соматотипа индивида

Олена Шишкіна, Ігор Бейгул, Алла Муллагільдіна

Вплив занять різними видами фітнесу з урахуванням оваріально-менструального циклу на психофізичний стан молодих жінок

Владимир Ревенко, Ярославна Пугач, Валерий Друзь, Вадим Артемьев

Современные методы контроля и оценки текущего функционального состояния спортсменов в различных видах единоборств

Людмила Канунова, Віктор Джим

Побудова тренувального процесу юних гирьовичок 12-13 років протягом річного макроциклу з урахуванням специфічного

біологічного циклу 


\section{SLOBOZANS'KIJ NAUKOVO-SPORTIVNIJ VISNIK}

\section{Editor in Chief}

Anatoliy Rovnyi, Doctor of Science (Physical Education and Sport), Professor, Academician of International Academy of Human Problems in Aviation and Aerospace (Kharkiv State Academy of Physical Culture, Ukraine)

Editorial board:

Oleksandr Azhippo, Doctor of Science (Pedagogical), Professor (Kharkiv State Academy of Physical Culture, Ukraine)

Volodymyr Ashanin, PhD (Mathematics and Physics), Professor, Academician ANPRE (Kharkiv State Academy of Physical Culture, Ukraine)

Eugeny Vrublevskiy, Doctor of Science (Pedagogical), Professor, Francisk Scorina Gomel State University (Belarus)

Valeriy Druz, Doctor of Science (Biology), Professor (Kharkiv State Academy of Physical Culture, Ukraine)

Oleg Kamaev, Doctor of Science (Physical Education and Sport), Professor (Kharkiv State Academy of Physical Culture, Ukraine)

Lesia Korobeynikova, Doctor of Science (Biology), Professor (National University of Physical Education and Sport of Ukraine, Ukraine)

Viacheslav Mulyk, Doctor of Science (Physical Education and Sport), Professor (Kharkiv State Academy of Physical Culture, Ukraine)

leonid Podrigalo, Doctor of Science (Medicine), Professor (Kharkiv State Academy of Physical Culture, Ukraine)

Yevhen Prystupa, Doctor of Science (Pedagogical), Professor (Lviv State University of Physical Culture, Ukraine)

Wojciech Czarny, Doctor of Science (Physical Culture), Professor (Uniwersytet Rzeszowski, Polska/ Poland)

Liudmyla Shesterova, PhD (Physical Education and Sport), Professor (Kharkiv Humanitarian-Pedagogical Academy, Ukraine)

Yuliya Kalmykova, PhD (Physical Therapy), Associate Professor, Kharkiv State Academy of Physical Culture, Ukraine

Mosab Saleem Hamed Amoudi, PhD (Physical Therapy), Arab American university, Jenin, Palestine

Mohammed Zerf, PhD, Physical Education Institut University Abdelhamid Ibn Badis de Mostaganem, Mostaganem, Algeria

\section{CONTENT}

Larysa Taran

Features of the activities of the First Gymnastic Society in the Kharkiv province at the end of the XIX and beginning of the XX century

Olena Tarasevich, Oleg Kamaev \& Daria Okun

Gender identification of athletes of different qualifications regarding classification groups of sports

Kateryna Tymruk-Skoropad, Iuliia Pavlova \& Nadiya Sydoryk Self-management strategy in training programs for patients with chronic obstructive pulmonary disease

\section{Margarita Mameshina}

Differentiation of the content of classes on physical education, taking into account indicators of physical health and physical preparedness of students in grades 7-9

\section{Yaroslav Kraynik, Vyacheslav Mulik, Daria Okun \&}

Svyatoslav Koval

Use of special exercises for the development of motor qualities and the formation of technical and tactical actions of defenders

13-14 years in the preparatory period

\section{Olena Bismak}

Algorithm for the use of physical therapy in patients with compression-ischemic neuropathies of the upper limb

\section{Valeriy Druz, Yaroslava Volkova \& Oleksii Huliaiev}

Prediction of prospects in dance and gymnastic sports based on the method of assessing the structure of an individual somatotype

Olena Shishkina, Igor Beihul \& Alla Mullagildina

Effect of different kinds of fitness based on the ovarian-menstrual

cycle on the psychophysical state of young women

\section{Volodymyr Revenko, Yaroslavna Puhach, Valeriy Druz \&}

\section{Vadym Artemiev}

Modern methods of monitoring and evaluating the current functional

state of athletes in various types of martial arts

\section{Liudmyla Kanunova \& Viktor Dzhym}

The construction of the training process of young weight lifters 12-13

years old during a one-year macrocycle, taking into account

the specific biological cycle 


\title{
Особливості діяльності Першого Гімнастичного Товариства у Харківській губернії наприкінці XIX та початку XX сторічь
}

\author{
Лариса Таран
}

Харківська державна академія фізичної культури, Харків, Україна

\begin{abstract}
Мета: встановити особливості та напрямки діяльності щодо розвитку фізичної культури і спорту на території Харківської губернії 1-го Гімнастичного Товариства.

Матеріал і методи: матеріалом дослідження слугували збережені рідкісні видання - "отчеты о деятельности Харьковскаго Гимнастическаго Общества за 1895, 1896, 1900, 1909 годы". Методи дослідження: аналіз і узагальнення даних наукової літератури, проблемно-пошуковий, історико-системний та логічний методи.

Результати: з'ясовано, що наприкінці XIX та початку XX століть спорт поширюється у великих містах, а основою для розвитку фізичної культури та спорту стають навчальні заклади та спортивні товариства. Харківське 1-ше Гімнастичне Товариство почало працювати одним із перших на Харківщині. Застосування різних форм організації занять дозволяло проводити широку агітаційну роботу серед населення Харкова щодо залучення до занять фізичною культурою та спортом, у тому числі жінок та дітей; сприяти розвитку видів спорту, які культивувало Товариство.

Висновки: у результаті дослідження встановлено рік заснування та засновників 1-го Гімнастичного Товариства. Розширено результати попередніх наукових досліджень щодо функціонування товариств наприкінці XIX та початку XX століть у наступних напрямках: організаційна структура та склад, функції викладача (тренера), залучення жінок і дітей до занять фізичною культурою, джерела прибутків та статті видатків, розклад та форми організації занять, діяльність 3 розвитку фізичної культури та окремих видів спорту на території Харківської губернії 1-го Гімнастичного Товариства.
\end{abstract}

Ключові слова: Гімнастичне Товариство, спортивний рух, фізична культура, спорт, Харківська губернія.

\section{Вступ}

Вивчення й аналіз збережених рідкісних видань дозволяє висвітлити особливості розвитку і становлення фізичної культури і спорту в різних регіонах України за часів, коли вона була складовою Російської імперії. Результати дослідження збагачують історичну спадщину галузі, вивчення якої є обов'язковою умовою для розвитку українського суспільства, його національної самосвідомості та самоідентифікації в умовах інтеграції до Європейського союзу.

Дослідженню розвитку спортивного руху у різних регіонах України наприкінці XIX та початку XX століть присвячені роботи багатьох науковців.

У монографії О. Вацеби (1997) встановлено, що перші українські спортові товариства виникають на Галичині на початку XX століття. Характерною ознакою їх розвитку було те, що більша частина з них функціонувала в рамках суто національних структур. Інші спортивні клуби включилися в офіційні структури польського спорту. Серед найбільш поширених видів спорту того часу - футбол, легка атлетика, гімнастика, лижний спорт, бокс, спортивні ігри.

Правові основи фізичної культури і спорту та, зокрема, спортивних організацій кінця XIX - початку XX століть розглянуто у роботах Л. Вострокнутова (2001), І. Гасюка (2009). За інформацією, висвітленою Л. Вострокнутовим (2001), можна дійти наступних висновків - розповсюдженню спорту та створенню Товариств сприяли: високий відсоток міського населення в Україні; наявність закладів освіти (університети, гімназії, училища); активна позиція передової громадськості - організаторами були представники інтелігенції; зростання міжнародного спортивного руху та його вплив.

Вивченню розвитку окремих видів спорту, створення спортивних товариств на Харківщині, починаючи з другої половини XIX століття, присвячена монографія М. Олійника та Ю. Грота (2002).

У науковій роботі О. Ляха-Породька (2009) розкрито становлення сокільського руху на території українських земель, що перебували у складі Російської імперії на початку XX століття.

У публікації А. Бондар (2012) висвітлено, що створення спортивних товариств, клубів, кружків на Слобожанщині у зазначений час сприяло зародженню ряду популярних у сьогоденні видів спорту - гімнастика, важка атлетика, боротьба, бокс, футбол, велоспорт.

Т. Устіновою (2012) досліджувався розвиток гімнастичного руху в контексті фізкультурної освіти країн Європи (друга половина XIX століття - 30-ті роки XX століття). Встановлено, що розвиток гімнастичного руху зумовлений основними напрямами фізкультурної освіти - гімнастичним, спортивно-ігровим та військово-фізичним.

Вивченню особливостей зародження та становлення фізкультурно-спортивного руху на Катеринославщині (нині Дніпропетровщина) у дореволюційний період (кінець XIX ст. - 1917 р.) присвячена праця авторів И. Балджи, Г. Саленко (2016). Серед перших спортивних організацій були створені "Екатеринославское общество циклистов (1894), "Екатеринославский (1897) и Каменской (1898) Яхт-клубы".

Наукова праця Г. Грибана (2018) присвячена історії діяльності спортивних товариств на Житомирщині у 18931922 роках. За встановленими даними великий вклад у розвиток фізичної культури на Житомирщині було зроблено навчальними закладами. Одним із перших спортивних товариств було відкрито Житомирське товариство велосипедистів-любителів (1893).

Отже, питання розвитку спортивного руху та створен- 


\section{SLOBOZANS'KIJ NAUKOVO-SPORTIVNIJ VISNIK}

ня спортивних товариств наприкінці XIX століття в Україні викликає зацікавленість у науковців з метою поширення маловідомих історичних фактів. Стосовно діяльності 1-го Гімнастичного Товариства необхідно уточнення щодо року його створення та засновників, потребують всебічного вивчення особливості його функціонування, як одного із провідних спортивних осередків на той час.

Мета дослідження: встановити особливості та напрямки діяльності з розвитку фізичної культури і спорту на території Харківської губернії 1-го Гімнастичного Товариства.

\section{Матеріал і методи дослідження}

Матеріалом дослідження слугували збережені рідкісн видання - "отчеты о деятельности Харьковскаго Гимнастическаго Общества за 1895, 1896, 1900, 1909 годы". Методи дослідження: аналіз і узагальнення даних наукової літератури, проблемно-пошуковий, історико-системний та логічний методи.

\section{Результати дослідження}

Наприкінці XIX століття у багатьох країнах бурхливо почав розвиватись спорт, чому сприяли певні умови. Спортивний рух оформлюється організаційно - створені міжнародні федерації гімнастики (1881), регбі (1886), гребл (1892) та міжнародний союз ковзанярів (1892). Поступово окремі види спорту набувають популярності і в Російській імперії, до складу якої відносилась Харківська губернія.

Як зазначає С. Філь [13], спортивно-гімнастичний рух в країні у другій половині XIX століття розвивається за зразками західних держав, тобто переважно для заможних і наближених до них громадян. Головною ознакою $€$ те, що спорт поширюється у великих містах. Як правило очолювали спортивні клуби (найчастіше як почесні) могутні банкіри, власники заводів тощо.

Сприяли становленню та розвитку спорту у багатьох випадках іноземні спеціалісти, а саме представники $\mathrm{Hi}$ меччини, Чехії та інших європейських держав. Це обумовлено відсутністю у країні спеціальних закладів для підготовки фахівців відповідного профілю. Основою для розвитку фізичної культури та спорту за тих часів стають навчальні заклади та спортивні товариства.

Одними із перших на Харківщині починають діяти Харківське товариство велосипедистів-аматорів (1887), Харківське 1-ше Гімнастичне Товариство (1894), Харківське Гімнастичне Товариство "Сокіл" (1907) та інші.

17 листопада 1893 року Міністерство внутрішніх справ Російської імперії затвердило Устав Гімнастичного Товариства за номером № 514, яке було засновано у 1894 році з метою - сприяти "...цьлям физическаго развитія нашего юношества и поддержанія здоровья среди населенія г. Харькова" [9]

Календарний рік починався з 1 лютого. Звіти про річну діяльність представлялися Губернатору, під наглядом якого воно перебувало, та Медичному Департаменту.

Із історії створення Гімнастичного Товариства: "М. м. Г. г. Многіе изъ Вась помнять очень хорошо, какъ зарождалось наше Общество. Возникнувъ первоначально, по мысли пяти лицъ, въ частномъ домь, на одной изъ отдаленныхъ удицъ г. Харькова, куда заходили немногіе поклонники и цьнители физическаго развитія, оно просуществовало всего лишь одинъ годъ, какъ стало тотчасъ- же очевидными, что ть рамки, въ которыхъ иніщіаторы дьла думали заключить свою задачу и дьятельность, дьлаются тьсньми. Всльдъ за этимъ, сознавая неотложную необходимость развить и укрьпить свою мысль на болье широкихъ и правильныхъ началахъ, ньсколько лиць первоначальнаго кружка любителей гимнастики, среди которыхъ приняли особенное участіе Г. г. Гельферихъ, Тофферъ, Мейеръ, Грозберъ, Гольцгютеръ, Бенцъ, Гнилинскій, Гутьяръ, Пильстремъ, Черевковъ, Вильгальмъ, Курце и другіе, рьшили основать въ г. Харьковь Гимнастическое Общество по типу тьхъ, которыя существовали уже заграницей и въ Россіи, какъ напр. въ Петербургь, Москвь и Одессь." [9]. Цей факт із звіту про діяльність Товариства за 1895 рік дозволяє назвати його засновників та свідчить, що воно було створено із гуртка любителів гімнастики

Також, за даними М. Олійника, Ю. Грота [8], причетним до організації Гімнастичного Товариства згадується Карл Августович Трепке, який займався успішною підприємницькою та благодійною діяльністю у місті.

З 1895 по 1901 роки, як зазначається у фінансовому звіті створеної організації, воно орендувало приміщення для занять у Римсько-Католицької церкви по вулиці Кокошкінській дом № 4 (сучасна адреса - вулиця Гоголя, 4) за щорічну плату 600 карбованців. У подальшому було орендовано приміщення Реального училища по вулиці Старомосковській (сучасна адреса - Московський проспект), при цьому плата складала у 1909-1911 роках 200 карбованців.

До складу Гімнастичного Товариства входили: голова, секретар, касир, члени ради або правління, викладачі, лікарі, почесний опікувач товариства (губернатор), почесні члени та дійсні члени. Головою Товариства у збережених звітах за 1895-1901 роки зазначається доктор медицини Олександр Михайлович Черевков, а у звіті за 1909 рік Павел Карлович Трепке.

Головним викладачем, або гімназіархом Товариства (у сучасному розумінні тренером), був Микола Федорович Вільгальм. (уродженець Харкова, закінчив курси Берлинського гімнастичного товариства. У 1913 році на Всеросійському зльоті гімнастів за успішний виступ спортсменів Харківського навчального округу імператор Микола II присвоїв М. Ф. Вільгальму звання "Гимназиарх всея Руси"). В його функції входило наглядати за гімнастичними заняттями, розміщувати відвідувачів по відділенням, призначати послідовність виконання різноманітних гімнастичних вправ та слідкувати за їх точним виконанням, призначати час відпочинку, не допускати надмірного охолодження тіла тощо.

Серед викладачів, які допомагали М. Ф. Вільгальму, значилися прізвища: Б. Краевскій (викладач фехтування, 1895), Гассельбррингъ, Гутьяръ, Рингсъ (керівники відділень, 1896), г-жа М. Е. Крушель (завідуюча дамською гімнастикою з 1896 року).

У складі Товариства були лікарі-д-ръ А. М. Черевковъ, Ю. Р. Пенский, М. Е. Крушель, завдяки чому відвідувачі знаходились під медичним наглядом та могли користуватись необхідними порадами з їх боку.

Як зазначено у витягу до уставу Товариства, воно складалося, окрім почесних та дійсних членів, ще з відвідувачів. Для дійсних членів та відвідувачів існували певні вікові обмеження. Дійсні члени могли бути не молодше 21 року, а вік відвідувачів мав становити 8 років та старше. Кількість дійсних членів Товариства, згідно до звітів про 


\section{СЛОБОЖАНСЬКИЙ НАУКОВО-СПОРТИВНИЙ ВІСНИК}

його діяльність $[9 ; 10 ; 11 ; 14]$ поступово зростає (рис. 1). З вересня 1896 року до складу дійсних членів включено жінок у зв'язку з тим, що Товариство відкрило курси гігієнічної гімнастики для жінок.

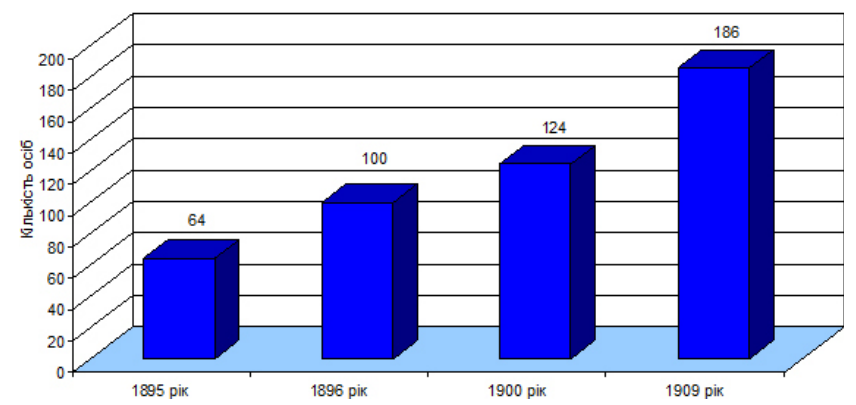

Рис. 1. Кількість дійсних членів 1-ого Гімнастичного Товариства у 1895, 1896, 1900, 1909 роках

Гімнастичне Товариство існувало на суспільних началах, на що вказує наступна цитата: "...безвозмездное служеніе всьхъ членовъ нашего Общества столь благому намьренію..." [9]. Єдиним, хто отримував жалування, був викладач гімнастики М. Ф. Вільгальм.

До основних джерел прибутків Товариства відносяться наступні: внески дійсних членів, відвідувачів, організація публічних вечорів, пожертвування Товариству.

Заняття гімнастикою у Товаристві були організовані на платній основі. Так, для дійсних членів це коштувало 10 карбованців на рік та 3 карбованці одноразово, при умові плати за півроку. Для відвідувачів оплата становила 1 карбованець на місяць або 10 карбованців на рік, при умові піврічного внеску.

Найбільші пожертвування поступали від почесного члена Товариства Максимиліана Христіановича Гельферихъ. Серед тих, хто допомагав Товариству фінансово або спортивним інвентарем, слід назвати прізвища Г. А. Пильстремъ, Б. А. Краєвскій, П. А. Носковъ, Н. І. Кудрячевский, М. С. Навратиль, Р. К. Мейеръ, В. И. Пидде.

Витрати Товариства були пов'язані з орендою приміщення, виплатою жалування викладачу та служителю, придбання та ремонт спортивного знаряддя, проведення публічних вечорів, призи для змагань, підписка журналів і таке інше.

У звіті Товариства за 1909 рік [14] представлено розклад або план занять для різних груп, які входили до його складу (таблиця 1). Згідно до розкладу лише дійсні члени могли займатися щодня (окрім суботи та неділі) по дві години. Для інших груп відвідувачів на тиждень планувалось два заняття з різною тривалістю: дорослі відвідувачі (чоловіки) займались протягом двох годин, дами та дівиці мали півтори години, а діти обох статей - одну годину.

При цьому існували "Правила для г. г. членовъ и посьтителей Харьковскаго Гимнастическаго Обще- ства", де зазначалось, що "...для лицъ болье опытныхъ разрьшаются вольныя упражненія не далье получаса, по истеченіи котораго никто не долженъ болье заниматься гимнастикой".

Певні вимоги існували й до спортивного одягу осіб, що займались гімнастикою: "...были по возможности въ однообразныхъ гимнастическихъ чистыхъ костюмахъ, т. е. въ синихъ брюкахъ и бьлой фуфайкь. Гимнастическіе же фуфайка и башмаки (или туфли) обязательны, ибо безъ нихъ къ упражненіямъ, никто не допускается" [14].

Товариство розвивало поряд із гімнастикою такі види спорту, як фехтування, важку атлетику, боротьбу [8].

Форми організації занять, які застосовувались у Товаристві були доволі різноманітні: гімнастичні вечори (тренувальні заняття), гімнастичні вечори "для испытанія результатовъ занятій", публічні та сімейні вечори, дитячі ігри, ялинка для дітей, вистави в театрі, загородні прогулянки, публічні літні змагання, змагання в цирку Муссурі, виступи з благодійною метою, виступи на гімнастичному святі, змагання на призи "за гимнастику", "за атлетику", "за борьбу". Застосування таких форм роботи Товариством дозволяло проводити широку агітаційну роботу серед населення Харкова із залучення до занять фізичною культурою та спортом, у тому числі жінок та дітей; сприяти розвитку видів спорту, які культивувало Товариство.

Аналізуючи показники відвідування зали, необхідно зазначити, що проведена робота мала позитивний вплив (таблиця 2). Так, кількість відвідувань дорослими за досліджуваний період поступово зростає, за виключенням 1900 р. Зниження показників у 1900 році обумовлено незручним приміщенням для занять, через те, що РимськоКатолицька церква, у якої воно орендується, зменшила площу користування для Товариства.

За 15 років існування спортивної організації збільшилися показники кількості відвідувань зали дорослими відвідувачами більше ніж у 8 разів, а кількості гімнастичних вечорів - у 1,7 рази.

Серед різних верств населення, які займались у залі Товариства у 1896 році, найбільша чисельність відвідувань у дорослих - 73\% (4585 разів), дійсних членів - 17\% (1092 рази) та дам - 10\% (602 рази). У 1900 році Товариством було організовано дитячі ігри [11]. Відповідно кількість відвідувань зали дітьми склала 8\% від загальної кількості (рис. 2).

Методичною основою роботи викладацькотренерського складу слугували "...два журнала, посвященные гимнастикь и спорту: Turner-Zeitung и Atleten- Zeitung", які отримувало товариство. Наочно були представлені різноманітні гімнастичні вправи у вигляді "19 таблицъ рисунковъ" [9]. Також на той час виходили перекладні роботи, присвячені фізичній культурі, у журналах публікували бібліографічні огляди книг з фізичного виховання, що видавалися у Росії [4]

Таблиця 1

План занять для груп Харківського 1-го Гімнастичного Товариства (1909-1910)

\begin{tabular}{|c|c|c|c|c|c|}
\hline \multirow{2}{*}{ Групи Товариства } & \multicolumn{5}{|c|}{ Дні тижня та час для занять } \\
\hline & Понеділок & Вівторок & Середа & Четвер & П’ятниця \\
\hline Дійсні члени & $20: 30-22: 30$ & $20: 30-22: 30$ & $20: 30-22: 30$ & $20: 30-22: 30$ & $20: 30-22: 30$ \\
\hline Дорослі відвідувачі I групи & & $20: 30-22: 30$ & & $20: 30-22: 30$ & \\
\hline Дорослі відвідувачі II групи & & & $20: 30-22: 30$ & & $20: 30-22: 30$ \\
\hline Дами та дівиці & $18: 30-20: 00$ & & & $18: 30-20: 00$ & \\
\hline Діти обох статей & & $18: 30-19: 30$ & & & $18: 30-19: 30$ \\
\hline
\end{tabular}




\section{SLOBOZANS'KIJ NAUKOVO-SPORTIVNIJ VISNIK}

Таблиця 2

Показники відвідування зали, проведених гімнастичних вечорів та змагань Харківського 1-го Гімнастичного Товариства $(1894-1896,1900,1909)$

\begin{tabular}{|c|c|c|c|c|c|}
\hline \multirow{2}{*}{ Показники } & \multicolumn{5}{|c|}{ Роки } \\
\hline & 1894 & 1895 & 1896 & 1900 & 1909 \\
\hline $\begin{array}{l}\text { Відвідування зали } \\
\text { (кіл-ть разів): }\end{array}$ & 1872 & 3526 & 6279 & 5416 & \\
\hline - Дійсними членами & & 566 & 1092 & 796 & \\
\hline - Дорослими відвідувачами & 1872 & 2960 & 4585 & 3835 & 15336 \\
\hline - Дамами та дівицями & & & 602 & 330 & \\
\hline - Дітьми (для дитячих ігор) & & & & 455 & \\
\hline Гімнастичних вечорів (кіл-ть) & 106 & 118 & 158 & 150 & 187 \\
\hline Змагань на призи (кіл-ть) & & & & 1 & 13 \\
\hline
\end{tabular}

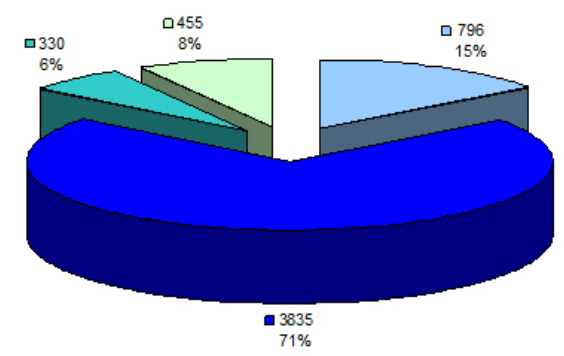

口- дійсні члени

-- Дорослі відвідувиі

口- Дами та дівиці

口- Dim

Рис. 2. Співвідношення різних категорій відвідувачів щодо кількості разів відвідування зали Гімнастичного Товариства у 1900 році

\section{Висновки / Дискусія}

У результаті дослідження встановлено, що Гімнастичне товариство засновано із гуртка любителів гімнастики у 1894 році при участі почесного члена Товариства Максимиліана Христіановича Гельферихъ - відомого у міст підприємця, мецената (який вносив найбільшу суму по- жертвувань) та інших осіб, що доповнює дані Л. Вострокнутова та уточнює відомості М. Олійника і Ю. Грота. Продовжено науковий пошук А. Бондарь, О. Вацеби, Г. Грибана, О. Ляха-Породька Т. Устінової, С. Філя та інших з історії розвитку спортивного руху у різних регіонах України наприкінці XIX та початку XX століття. Підтверджено дані И. Балджи, Г. Саленко щодо фінансування перших спортивних організацій. Розширено результати попередніх наукових досліджень щодо функціонування товариств у наступних напрямках: організаційна структура та склад, функції викладача (тренера), залучення жінок і дітей до занять фізичною культурою, джерела прибутків та статті видатків, розклад та форми організації занять, діяльність з розвитку фізичної культури та окремих видів спорту (гімнастика, фехтування, боротьба, важка атлетика) на території Харківської губернії 1-го Гімнастичного Товариства.

Перспективи подальших досліджень пов'язані 3 узагальненням звітів про діяльність товариств з інших видів спорту, які були засновані того часу у Харківській губернії.

Конфлікт інтересів. Автор заявляє, що немає конфлікту інтересів, який може сприйматися таким, що може завдати шкоди неупередженості статті. Джерела фінансування. Ця стаття не отримала фінансової підтримки від державної, громадської або комерційної організацій.

\section{Список посилань}

1. Балджи, И., Саленко, Г. (2016), "Физкультурно-спортивное движение в Екатеринославской губернии в дореволюционный период (конец XIXв. - 1917 г.)", Спортивний вісник Придніпров'я, № 1, С. 152-157.

2. Бондарь, А.С. (2012), "История развития и традиции спорта на Слобожанщине", Слобожанський науково-спортивний вісник, № 5, C. 156-159.

3. Вацеба, О. (1997), Нариси з історії західноукраїнського спортивного руху, Івано-Франківськ.

4. Вострокнутов, Л.Д. (2001), "Нормативно-правова основа діяльності спортивних організацій в Україні (кінець XIX - поч. XX ст.)", Вісник Харківського національного університету внутрішніх справ, Випуск 15, С. 151-155.

5. Гасюк, І.Л. (2009), "Еволюція організаційно-правових основ державного управління фізичною культурою й спортом на українських землях наприкінці XIX століття та в радянський період", Університетські наукові записки, № 4 (32), С. 261-272.

6. Грибан, Г.П. (2018), "Історія діяльності спортивних товариств на Житомирщині в 1893-1922 роках", Фізична культура, спорт та здоров'я нації, № 5, С. 446-453.

7. Лях-Породько, О.О. (2009), "Особливості становлення сокільського руху на українських землях Російської імперії на початку XX століття", Теорія і методика фізичного виховання і спорту, № 1, С. 86-99.

8. Олейник, Н.А., Грот, Ю.И. (2002), История физической культуры и спорта на Харьковщине, Т. 1, С. 5-11.

9. Отчет о деятельности Харьковскаго Гимнастическаго Общества за 1895 (1896), Харьковъ, 19 с.

10. Отчет о деятельности Харьковскаго Гимнастическаго Общества за 1896 (1897), Харьковъ, 15 с.

11. Отчет о деятельности Харьковскаго Гимнастическаго Общества оть 1-го февраля 1900 г. по 1-е февраля 1901 г. (1901), Харьковъ, $13 \mathrm{c}$

12. Устінова, Т. (2012), "Розвиток гімнастичного руху в контексті фізкультурної освіти країн Європи (друга половина ХІХ століття - 30-ті роки XX століття)", Теорія і методика фізичного виховання і спорту, № 3, С. 134-138.

13. Філь, С.М., Худолій, О.М., Малка, Г.В. (2003), Історія фізичної культури, С. 99-101.

14. Харьковское 1-е Гимнастическое Общество. Годичный отчеть съ 1-го февраля 1909 года по 1-е февраля 1910 года (1910), Харьковъ, 15 с.

Стаття надійшла до редакції: 25.10.2019 р. 


\section{СЛОБОЖАНСЬКИЙ НАУКОВО-СПОРТИВНИЙ ВІСНИК}

Опубліковано: 30.12.2019 p.

Аннотация. Лариса Таран. Особенности деятельности Первого Гимнастического Общества в Харьковской губернии в конце XIX и начале XX века. Цель: установить особенности и направления деятельности по развитию физической культуры и спорта на территории Харьковской губернии 1-го Гимнастического Общества. Материал и методы: материалом исследования послужили сохраненные редкие издания - "отчеты о деятельности Харьковскаго Гимнастическаго Общества за 1895, 1896, 1900, 1909 годы". Методы исследования: анализ и обобщение данных научной литературы, проблемно-поисковый, историко-системный и логический методы. Результаты: в конце XIX и начале XX века спорт распространяется в крупных городах, а основой для развития физической культуры и спорта становятся учебные заведения и спортивные общества. Харьковское 1-ое Гимнастическое Общество начало работать одним из первых на Харьковщине. Применение различных форм организации занятий позволяло проводить широкую агитационную работу среди населения Харькова по привлечению к занятиям физической культурой и спортом, в том числе женщин и детей; способствовать развитию видов спорта, которые культивировало Общество. Выводы: в результате исследования установлены год основания и учредители 1-го Гимнастического Общества. Расширены результаты предыдущих научных исследований по функционированию обществ в конце XIX и начале XX века в следующих направлениях: организационная структура и состав, функции преподавателя (тренера), привлечение женщин и детей к занятиям физической культурой, источники доходов и статьи расходов, расписание и формы организации занятий, деятельность по развитию физической культуры и отдельных видов спорта на территории Харьковской губернии 1-го Гимнастического Общества.

Ключевые слова: Гимнастическое Общество, спортивное движение, физическая культура, спорт, Харьковская губерния.

Abstract. Larysa Taran. Features of the activities of the First Gymnastic Society in the Kharkiv province at the end of the XIX and beginning of the XX century. Purpose: to establish the features and areas of activity for the development of physical culture and sports in the territory of the Kharkiv province of the 1st Gymnastic Society. Material \& Methods: the research material was preserved in rare editions - reports on the activities of the Kharkiv Gymnastic Society for 1895, 1896, 1900, 1909. Research methods: analysis and synthesis of scientific literature data, problem-search, historical-systemic and logical methods. Results: revealed that at the end of the 19th and the beginning of the 20th centuries, sports spread in large cities, and educational institutions and sports societies became the basis for the development of physical culture and sports. Kharkiv 1st Gymnastic Society began to work one of the first in the Kharkiv region. The use of various forms of organization of classes made it possible to carry out extensive campaigning among the population of Kharkiv to attract physical education and sports, including women and children; contribute to the development of sports that the Society has cultivated. Conclusions: as a result of the study, the year of foundation and founders of the 1st Gymnastic Society was established. The results of previous scientific studies on the functioning of societies at the end of the 19th and beginning of the 20th centuries were expanded in the following areas: organizational structure and composition, functions of a teacher (trainer), attracting women and children to physical education, sources of income and expense items, timetable and forms of organization of classes, activities for the development of physical education and individual sports in the territory of Kharkiv province, the 1st Gymnastic Society.

Keywords: Gymnastic Society, sports movement, physical education, sport, Kharkiv province.

\section{References}

1. Baldzhi, I. \& Salenko, G. (2016), "Physical Culture and Sports Movement in the Yekaterinoslav Province in the Pre-Revolutionary Period (End of the 19th Century - 1917)", Sportivniy visnik Pridniprov'ya, No. 1, pp. 152-157. (in Russ.)

2. Bondar, A.S. (2012), "The History of the Development and Traditions of Sports in the Slobozhanshchina", Slobozans'kij naukovosportivnij visnik, No. 5, pp. 156-159. (in Russ.)

3. Vatseba, O. (1997), Narysy z istorii zakhidnoukrainskoho sportyvnoho rukhu [Essays on the History of Western Ukrainian Sports Movement], Ivano-Frankivsk. (in Ukr.)

4. Vostroknutov, L.D. (2001), "The Legal Basis of Activity of Sports Organizations in Ukraine (End of XIX - Beginning of XX Century)", Visnyk Kharkivskoho natsionalnoho universytetu vnutrishnikh sprav, Vypusk 15, pp. 151-155. (in Ukr.)

5. Hasiuk, I.L. (2009), "The evolution of the organizational and legal foundations of public management of physical culture and sports in the Ukrainian lands at the end of the 19th century and in the Soviet period", Universytetski naukovi zapysky, No. 4 (32), pp. 261-272. (in Ukr.)

6. Hryban, H.P. (2018), "The History of Activity of Sports Societies in Zhytomyr Region in 1893-1922", Fizychna kultura, sport ta zdorovia natsii, No. 5, pp. 446-453. (in Ukr.)

7. Liakh-Porodko, O.O. (2009), "Peculiarities of Formation of the Falcon Movement in the Ukrainian Lands of the Russian Empire at the Beginning of the XX Century", Teoriia i metodyka fizychnoho vykhovannia i sportu, No 1, pp. 86-99. (in Ukr.)

8. Oleynik, N.A. \& Grot, Yu.I. (2002), Istoriya fizicheskoy kultury i sporta na Kharkovshchine [The history of physical culture and sports in the Kharkov region], Vol. 1, pp. 5-11. (in Russ.)

9. Report on the activities of the Kharkov Gymnastic Society for 1895 (1896), Kharkiv, 19 p. (in Russ.)

10. Report on the activities of the Kharkov Gymnastic Society for 1896 (1897), Kharkiv, 15 p. (in Russ.)

11. Report on the activities of the Kharkov Gymnastic Society from February 1, 1900 to February 1, 1901 (1901), Kharkiv, 13 p. (in Russ.)

12. Ustinova, T. (2012), "The Development of Gymnastic Movement in the Context of Physical Education in Europe (Second Half of the 19th Century - 30s of the 20th Century)", Teoriia i metodyka fizychnoho vykhovannia i sportu, No. 3, pp. 134-138. (in Ukr.)

13. Fil, S.M., Khudolii, O.M. \& Malka, H.V. (2003), Istoriia fizychnoi kultury [History of Physical Culture], pp. 99-101. (in Ukr.) 14. Kharkov 1st Gymnastic Society. Annual report from February 1, 1909 to February 1, 1910 (1910), Kharkov, 15 p. (in Russ.)

Received: 25.10 .2019

Published: 30.12 .2019

\section{Відомості про авторів / Information about the Authors}

Таран Лариса Миколаївна: к. фіз. вих., доцент; Харківська державна академія фізичної культури: вул. Клочківська, 99, м. Харків, 61058, Україна.

Таран Лариса Николаевна: к. физ. восп., доцент; Харьковская государственная академия физической культуры: ул. Клочковская 99, г. Харьков, 61058, Украина

Larysa Taran: PhD (Physical Education and Sport); Kharkiv State Academy of Physical Culture: Klochkivska str. 99, Kharkiv, 61058, Ukraine.

ORCID.ORG/0000-0001-8141-443X

E-mail: taranlarisa11@gmail.com 


\title{
Гендерна ідентифікація спортсменів різної кваліфікації відносно класифікаційних груп видів спорту
}

\author{
Олена Тарасевич \\ Олег Камаєв \\ Дар'я Окунь
}

Харківська державна академія фізичної культури, Харків, Україна

\begin{abstract}
Мета: визначити гендерні типи спортсменів різної кваліфікації з урахуванням статі в залежності від класифікаційних груп видів спорту.

Матеріал і методи: у дослідженні приймали участь 859 студентів і студенток віком 17-28 років, які навчаються у Харківській державній академії фізичної культури, Національному університеті фізичного виховання і спорту України $i$ Сумському державному педагогічному університеті імені А. С. Макаренка, що займаються олімпійськими і неолімпійськими видами спорту і мають різну спортивну кваліфікацію. З них 428 спортсменок і 431 спортсмен. Використані такі методи дослідження, як: аналіз та узагальнення літературних джерел і інтернет-ресурсів з досліджуваної проблеми; анкетування; опитування; психологічні методи: методика С. Бем "Маскулінність / фемінінність"; методи математичної статистики.

Результати: виявлено відсоткове співвідношення маскулінних, фемінінних і андрогінних типів особистості серед 859 досліджуваних, які спеціалізуються у спортивних іграх і єдиноборствах, у циклічних, швидкісно-силових і складнокоординаційних видах спорту. 3 маскулінним типом особистості виявлено 238 юнаків, що складає 55\% від загальної кількості спортсменів і 238 дівчат (56\% від їх загальної кількості). Спортсменів андрогінного типу виявлено 193 особи (45\%), а спортсменок - 190 - це 44\%. Особистостей фемінінного типу ні серед юнаків, ні серед дівчат виявлено не було. Також виявлено відсоткове співвідношення маскулінних і андрогінних спортсменів і спортсменок у різних класифікаційних групах видів спорту і спортивних дисциплін відносно їх біологічної статі та спортивної кваліфікації.

Висновки: відносно такого поняття, як "гендер", чоловіки і жінки відносяться до однієї з трьох соціокультурних статей: маскулінної, фемінінної або андрогенної. Уявлення про мужність (маскулінність) і жіночість (фемінінність) пов'язані не с біологічною статтю людини, а саме з типом культури, до якої вона належить. Спорт, як інститут соціалізації, активно сприяє формуванню гендерних якостей особистості. У результаті дослідження доведено, що співвідношення гендерних типів особистості і у чоловіків, і у жінок змінюється залежно від виду спортивної діяльності, якою вони займаються. Висока кваліфікація спортсменів і спортсменок сприяє формуванню у них маскулінності.
\end{abstract}

Ключові слова: гендер, чоловіки, жінки, маскулінність, фемінінність, андрогінність, гендерна ідентичність.

\section{Вступ}

Під поняттям "гендер", яке ввів у науку американський психоаналітик Роберт Столлер у 1958 році, розуміють соціальну стать, що визначає поведінку людини в суспільстві і те, як ця поведінка сприймається [7; 8; 14]. Пропозиція Р. Столлера про розведення біологічної і культурної складової у вивченні питань, пов'язаних зі статтю, і дало поштовх формуванню особливого напрямку в сучасному гуманітарному знанні - гендерним дослідженням, які активно почали проводитися з 60-70-х років XX сторіччя.

Поняття маскулінності і фемінінності виявляють нормативні уявлення і установки, якими повинні бути, і отже, чим повинні займатися чоловіки і жінки у даному суспільстві і в даний час. Маскулінність і фемінінність $€$ соціальними, а не біологічними категоріями. Вони визначають нашу гендерну ідентичність і безпосередньо пов'язані з нашими уявленнями про себе та інших. Гендерна ідентичність - це усвідомлення своєї належності до певної статі та готовність дотримуватися відповідних суспільних гендерних норм [9; 10].

Уявлення про мужність (маскулінність) і жіночість (фемінінність) пов'язані не лише з біологічною статтю людини, а також і з соціально-психологічною статтю особистості. Розуміння схожості і відмінності біологічної і соціальнопсихологічної статі допомагає визначитися людині у жит- ті, у професійній діяльності, тому числі і у спортивній діяльності [1;2].

Проблема формування маскулінності або фемінінності викликає досить багато суперечок і розходжень у поглядах, зокрема, у питанні про те - чи є ці компоненти особистості уродженими чи тими, що були придбані у ході розвитку особистості.

Питаннями статевих відмінностей займалися такі автори, як E. E. Maccoby, C. N. Jacklin (1974), S. L. Bem (1979; 1983; 1993; 2004), K. Deaux, B. Major (1987), D. A. Gentile (1993), R. K. Under, M. Crawford (1993), A. Feingoid (1994), J. Homsby (1995), І. С. Клецина (1998; 2003; 2009), Ш. Бьорн (2001), Н. Г. Цикунова (2003), І. І. Таран (2004), Т. В. Бендас (2006), Є. П. Іль'їн (2003; 2010), О. Вейнингер (2012), Д. Б. Вершиніна (2017), А. В. Воронова (2014, $2015,2018)$, Н. А. Скоморохова (2018) та інші. Але в більшості їх роботи стосувалися гендерної психології.

Діяльність, якою займається той чи інший індивідуум, іï характер не може не впливати на змінювання структури особистості. Спорт є однією з високоспецифічних сфер діяльності людини, i, як інститут соціалізації, активно сприяє формуванню гендерних якостей особистості $[11 ; 12]$.

Кожна людина, незважаючи на біологічну стать, має в собі поєднання як мужності (маскулінності), так і жіночості (фемінінності). Сукупність цих складових формує низку перехідних форм з перевагою або маскулінності, або фе- 


\section{СЛОБОЖАНСЬКИЙ НАУКОВО-СПОРТИВНИЙ ВІСНИК}

мінінності. У достатньо великій кількості випадків спостерігається однаковий внесок обох починань у загальну сутність людини. Поєднання маскулінних і фемінінних ознак поведінки, тобто явище, при якому людина проявляє одночасно і чоловічі і жіночі якості, формує андрогінний тип особистості. Маскулінність, фемінінність і андрогінність це не біологічні, а соціальні категорії, які відображають стереотипні уявлення про особистісні характеристики, зовнішність, поведінку, інтереси, міжособистісні відношення чоловіків і жінок та їх професійні заняття [3; 8].

Гендерні ролі завжди пов'язані зі специфікою нормативної системи, яка визнана в тому чи іншому соціокультурному середовищі, яку особистість засвоює і проецирує на свою поведінку [4; 6]. Але наскільки глибинні, поворотні чи ні ці зміни особистості, яка різниця в цьому питанні між чоловіками і жінками, що спонукає їх займатися певними видами спортивної діяльності, як і в якій мірі впливає це на змінення структури особистості? Ці питання, а також питання співвідношення біологічної і соціальнопсихологічної статі особливо гостро стоять в останні часи у зв'язку з поширенням видів спорту і спортивних дисциплін, якими почали займатися жінки. У теперішній час дівчата змагаються у тих видах спорту, які до недавнього часу вважалися традиційно чоловічими. У них спортсменки виявляють нетипові у межах соціуму, а часто і з біологічної точки зору, особливості поведінки [5; 15].

У даний час більшість наукових досліджень таких авторів, як Н. Г. Цикунова (2003), О. Л. Ворожбитова (2007), Т. В. Артамонова; Т. А. Шевченко (2009), Ш. К. Шахов, А. С. Дамадаєва (2011), Т. Ю. Маскаєва, Г. М. Германов (2014), Д.І.Джурмій (2015), К. А. Бугаевский (2016; 2017; 2018) та інших спрямовано на формування гендерних типів спортсменів у різних видах спорту. Але питання, які види спорту в більшій мірі сприяють формуванню тих чи інших гендерних властивостей вивчено не достатньо. У зв'язку з цим дана робота присвячена визначенню особливостей формування гендерних типів спортсменів у залежності від їх спортивної кваліфікації та класифікаційних груп видів спорту набуває своєчасність і актуальність.

Мета дослідження: визначити гендерні типи спортсменів різної кваліфікації з урахуванням статі і в залежності від класифікаційних груп видів спорту.

\section{Матеріал і методи дослідження}

Методи дослідження. Використані такі методи дослідження як: аналіз та узагальнення літературних джерел і інтернет-ресурсів з досліджуваної проблеми; анкетування; опитування; психологічні методи: методика С. Бем "Маскулінність / фемінінність", що діагностує психологічну стать і виявляє ступінь андрогінності, маскулінності і фемінінності особистості [16]; методи математичної статистики.

Матеріал дослідження. У дослідженні приймали участь 859 студентів і студенток віком 17-28 років, які навчаються у Харківській державній академії фізичної культури, Національному університеті фізичного виховання і спорту України і Сумському державному педагогічному університеті імені А. С. Макаренка, що займаються олімпійськими і неолімпійськими видами спорту і мають різну спортивну кваліфікацію (від спортсменів масових розрядів до тих, що мають звання 3МС). 3 них 428 спортсменок і 431 спортсмен, які спеціалізуються у таких видах спорту і спортивних дисциплінах, як: дзюдо, самбо, бокс, кікбоксинг, карате, тхеквондо, вільна боротьба, греко-римська боротьба, змішані єдиноборства, тайський бокс, рукопашний бій, капоейра, греплінг, легка атлетика, лижні гонки, плавання, шорт-трек, академічне веслування, спортивне орієнтування, велоспорт, спортивний туризм, триатлон, біатлон, кінний спорт, парусний спорт, парашутний спорт, гребний слалом, фітнес, сучасні танці, фігурне катання, стрибки у воду, синхронне плавання, художня гімнастика, естетична гімнастика, спортивна гімнастика, воркаут, стрибки на акробатичній доріжці, стрибки на батуті, спортивна акробатика, акробатичний рок-н-рол, спортивна аеробіка, черлідінг, спортивні бальні танці, стрільба з луку, автоспорт, мотоспорт, альпінізм, волейбол, бадмінтон, теніс, хокей, водне поло, гандбол, баскетбол, настільний теніс, бейсбол, боулінг, петанк, шахи, футбол, регбі, важка атлетика, пауерліфтинг, гирьовий спорт, армспорт, бодібілдинг.

Види спорту та спортивні дисципліни, якими займаються досліджувані було поділено на групи відносно найбільш розповсюдженої класифікації, що відображує специфіку рухів, а також структуру змагальної і тренувальної діяльності (за В. Н. Платоновим).

\section{Результати дослідження}

У різних видах спорту до особистості спортсменів висуваються і різні вимоги. В одних видах - від них вимагають прояву більш високого рівня агресивності, сміливості, рішучості, напористості, сили; у других - підвищеної артистичності, чуттєвості, експресивності, емоційності, граціозності; у третіх - прояву логічного мислення, здатності швидко орієнтуватися та приймати рішення у нестандартних ситуаціях, гарної пам'яті і т. п. Таким чином, той чи інший вид спортивної діяльності має вплив на формування гендерного типу спортсменів [13].

У процесі дослідження в усіх спортсменів і спортсменок, як кваліфікованих, так і розрядників, було виявлено відсоткове співвідношення маскулінніх, фемінінних і андрогінних типів особистості. 3 маскулінним типом особистості було виявлено 238 спортсменів, що складає 55\% від їх загальної кількості, а з андрогінним - 193 чоловіка, відповідно - 45\%. Юнаків, які мають фемінінній тип особистості під час дослідження виявлено не було.

Аналогічну ситуацію ми спостерігаємо і у дівчат. Спортсменок $з$ фемінінним типом особистості не виявлено. Усього в дослідженні прийняли участь 428 спортсменок, із них дівчат маскулінного типу виявлено 238, тобто 56\%, а андрогінного 190 - це складає 44\%.

Бачимо, що відносно загальної кількості досліджуємих, відсоткове співвідношення юнаків і дівчат, що займаються різними видами спорту, майже ідентично.

Відсутність спортсменів і спортсменок з фемінінним гендерним статусом свідчить про те, що спортивна діяльність висуває певні вимоги до особистості людини і позначається певним чином на людях, що займаються спортом.

При багаторічних заняттях спортом у більшій мірі розвиваються такі якості особистості, які притаманні маскулінному типу: активність, самостійність, незалежність, сміливість, напористість, проявлення волі, здатність протистояти труднощам, вміння добиватися поставлених цілей, готовність до ризику і т. п.

Головними характеристиками фемінінності є: м'якість, ніжність, поступливість, залежність від оточуючих, пасив- 


\section{SLOBOZANS'KIJ NAUKOVO-SPORTIVNIJ VISNIK}

ність, боязливість і т. п. Якщо людина має такий набір якостей, високих спортивних результатів вона добитися не зможе. Тому люди, яким притаманні такі якості або вибирають інший вид діяльності, або їх психічні властивості і властивості поведінки трансформуються і набувають чоловічих характеристик.

Для андрогінності притаманне поєднання характеристик маскулінності і фемінінності, тобто злиття в єдине ціле домінантного чоловічого початку і емоційноекспресивного - жіночого.(Т. В. Артамонова, Т. А. Шевченко).

Відносно класифікаційних груп видів спорту і статевої ознаки було виявлено соціокультурну стать досліджуваних і відсоткове співвідношення представників різних гендерних типів особистості серед спортсменів і спортсменок, що спеціалізуються в складнокоординаційних, швидкісносилових, циклічних видах спорту, спортивних іграх і єдиноборствах. Юнаків і дівчат, які займаються багатоборствами і комбінованими видами спорту недостатньо, щоб проводити аналіз (6 спортсменів і 8 спортсменок). Тому ця група не розглядалася у нашому дослідженні.

У швидкісно-силових видах спорту спортсменів з андрогінним типом особистості під час дослідження виявлено більше, ніж спортсменок з таким же типом (45\% юнаків і 27\% дівчат). А спортсменів маскулінного типу менше, ніж спортсменок цього типу (55\% юнаки і 73\% дівчата).

Однак і серед спортсменів і серед спортсменок, що займаються важкою атлетикою, пауерліфтингом, гирьовим спортом, армрестлінгом, бодібілдінгом, переважають юнаки і дівчата маскулінного типу, але різниця між маскулінними і андрогінними спортсменами не суттєва, а у спортсменок ця різниця досить велика.

Якщо зрівнювати спортсменок і спортсменів у циклічних видах спорту відносно належності до тієї чи іншої соціокультурної статі, то серед дівчат більше осіб маскулінного типу (54\%), а серед юнаків - андрогінного (52\%).

У складнокоординаційних видах спорту маскулінними є 45\% юнаків, а андрогінними - 55\%. У жінок цей показник: 53\% - маскулінних спортсменок і 47\% - андрогінних. Таким чином, у юнаків переважають особи андрогінного типу, а у дівчат - маскулінного типу.

У спортивних іграх виявлена перевага і маскулінних спортсменів, і маскулінних спортсменок над андрогінними (у юнаків співвідношення 60\% - маскулінних і 40\% - андрогінних; у дівчат - 59\% - маскулінних і 41\% - андрогінних).

При порівнянні юнаків і дівчат відносно їх гендерного типу спостерігаємо, що спортсменів маскулінного типу не на багато більше, ніж спортсменок цього ж типу (60\% юнаків і 59\% - дівчат), а серед респондентів з андрогенним типом спостерігається незначна перевага з боку спортсменок (41\% - дівчат і 40\% - юнаків). Таким чином можна зробити висновок, що в результаті дослідження в спортивних іграх виявлена майже однакова кількість спортсменів і спортсменок маскулінної і андрогінної стаTi.

У спортивних єдиноборствах спостерігається картина схожа зі спортивними іграми. I у спортсменів, і у спортсменок виявлено більшу кількість осіб маскулінного типу (56\% - дівчат і 58\% - юнаків).

Що стосується порівняння співвідношення маскулінних спортсменів-єдиноборців і спортсменок, що займаються дзюдо, самбо, карате, тхеквондо, вільною боротьбою, боксом тощо, виявлено більшу кількість маскулінних юнаків (58\%), ніж дівчат (56\%). А ось спортсменок, що мають андрогінний тип особистості, більше (42\%), ніж спортсменів (44\%). Але ця перевага незначна і для маскулінного, і для андрогінного типів особистості.

Спостерігається перевага маскулінних дівчат у всіх класифікаційних групах видів спорту. Серед юнаків більшу кількість маскулінних спортсменів виявлено у спортивних єдиноборствах, спортивних іграх і швидкісно-силових видах спорту.

На наступному етапі дослідження було виявлено відсоткове співвідношення гендерних типів особистості серед спортсменів і спортсменок, які спеціалізуються у видах спорту, що відносяться до різних класифікаційних груп, відносно їх спортивної кваліфікації.

Усі досліджувані відносно їх біологічної статі були поділені на дві групи. Перша група - це кваліфіковані спортсмени і спортсменки. До них відносяться ті, хто мають звання ЗМС, МСMК, MC і КМС. Друга група - це спортсменирозрядники (1 і 2 спортивні розряди).

При порівнянні усіх досліджуваних юнаків і дівчат відносно їх гендерного типу і їх кваліфікації виявили, що висококваліфікованих маскулінних спортсменок більше за висококваліфікованих маскулінних спортсменів. Серед висококваліфікованих андрогінних осіб виявлено більше спортсменок, ніж спортсменів.

Серед спортсменів-розрядників - юнаків маскулінного типу більше, ніж маскулінних дівчат. Серед андрогінних осіб, що мають 1 і 2 спортивні розряди спостерігається невелика перевага на користь спортсменок (таблиця).

При порівнянні спортсменів і спортсменок, що мають високі спортивні досягнення, відносно їх гендерної статі з'ясовано, що серед кваліфікованих спортсменів і спортсменок більше осіб маскулінного типу, а серед спортсменів і спортсменок, що мають спортивні розряди - у юнаків спостерігаємо співвідношення маскулінних і андрогінних осіб 48:52\%, а у дівчат - спортсменок з андрогінним типом більше, чим з маскулінним.

Із вищевикладеного можна зробити висновок, що висока кваліфікація спортсменів і спортсменок сприяє формуванню у них маскулінності. Для того, щоб досягти висо-

Співвідношення висококваліфікованих спортсменів і спортсменок і тих, що мають масові розряди, відносно гендерного типу особистості, \%

\begin{tabular}{|c|c|c|c|c|}
\hline \multirow{3}{*}{$\begin{array}{c}\text { Гендерний тип } \\
\text { особистості }\end{array}$} & \multicolumn{4}{|c|}{ Біологічна стать } \\
\hline & \multicolumn{2}{|c|}{ Юнаки (n=431) } & \multicolumn{2}{|c|}{ Дівчата (n=428) } \\
\hline & Висококваліфіковані & Розрядники & Висококваліфіковані & Розрядниці \\
\hline Маскулінний & 58 & 48 & 63 & 37 \\
\hline Андрогінний & 42 & 52 & 45 & 55 \\
\hline Фемінинний & 0 & 0 & 0 & 0 \\
\hline
\end{tabular}




\section{СЛОБОЖАНСЬКИЙ НАУКОВО-СПОРТИВНИЙ ВІСНИК}

ких спортивних результатів треба багато і плідно тренуватися, ставити перед собою цілі і досягати їх, бути психічно і фізично готовими до великих навантажень, у потрібний час вміти мобілізувати всі резерви свого організму і ще багато чого. Для реалізації всього цього треба володіти комплексом якостей, які в соціумі характеризуються як маскулінні.

При виявленні і порівнянні відсоткового співвідношення гендерних типів спортсменів і спортсменок відносно їх спортивної кваліфікації в різних класифікаційних групах видів спорту було з'ясовано, що найбільша кількість кваліфікованих маскулінних спортсменок (90\%) і кваліфікованих маскулінних спортсменів (71\%) є в спортивних єдиноборствах. Висококваліфікованих андрогінних дівчат - у складнокоординаційних видах спорту (63\%), а андрогінних юнаків - у спортивних єдиноборствах $(60 \%)$ і в циклічних видах спорту (59\%).

Серед спортсменок-розрядниць маскулінних дівчат більше у швидкісно-силових видах спорту (50\%), а маскулінних спортсменів невисокої спортивної кваліфікації - у спортивних іграх (74\%). Андрогінні дівчата, що мають 1 і 2 спортивні розряди переважають у циклічних видах спорту (68\%), а юнаки цього гендерного типу - у спортивних іграх (69\%) та у швидкісно-силових видах спорту (67\%).

\section{Висновки / Дискусія}

Відносно такого поняття, як "гендер", чоловіки і жінки відносяться до однієї з трьох соціокультурних статей: маскулінної, фемінінної або андрогенної. Уявлення про мужність (маскулінність) і жіночість (фемінінність) пов'язані не с біологічною статтю людини, а саме з типом культури, до якої вона належить.

Спорт, як інститут соціалізації, активно сприяе формуванню гендерних якостей особистості. У результаті дослідження доведено, що співвідношення гендерних типів особистості і у чоловіків, і у жінок змінюється залежно від виду спортивної діяльності, якою вони займаються.

У результаті дослідження серед 859 спортсменів і спортсменок не виявлено осіб, що мають фемінінний тип особистості. Це свідчить про те, що спортивна діяльність висуває певні вимоги до особистості людини і трансформує їі. Виявлено, що відсоткове співвідношення маскулінних юнаків (55\%) і дівчат (56\%) та андрогінніх юнаків (45\%) і дівчат (44\%), що займаються різними видами спорту майже однакове.

Висока кваліфікація спортсменів і спортсменок сприяє формуванню у них маскулінності. Це можна пояснити тим, що у м'язах при фізичному навантаженні відбувається метаболізм андрогенів - чоловічих статевих гормонів. У спортсменів м'язова тканина гарно розвинена і тому в більшій мірі відбувається маскулінізація і чоловіків, і жінок, що займаються спортом.

При виявленні і порівнянні відсоткового співвідношення гендерних типів спортсменів і спортсменок відносно їх спортивної кваліфікації в різних класифікаційних групах видів спорту було з'ясовано, що найбільша кількість кваліфікованих маскулінних спортсменок і спортсменів є в спортивних єдиноборствах (відповідно 90\% і 71\%). Кваліфікованих андрогінних дівчат - у складнокоординаційних видах спорту (63\%), а юнаків - у спортивних єдиноборствах (60\%) і в циклічних видах спорту $(59 \%)$.

Перспектива подальших досліджень у даному напрямку. Щодо даної теми - подальші дослідження планується вести у напрямку визначення показників особистості (за опитувальником Кеттелла) у спортсменів і спортсменок, які спеціалізуються в різних видах спорту відносно їх біологічної статі, гендерного типу і спортивної кваліфікації, а також з'ясування схожості і відмінності гендерних стереотипів, життєвих установок, мотивів і цілей занять спортом.

Конфлікт інтересів. Автори заявляють, що немає конфлікту інтересів, який може сприйматися таким, що може завдати шкоди неупередженості статті. Джерела фінансування. Ця стаття не отримала фінансової підтримки від державної, громадської або комерційної організацій.

\section{Список посилань}

1. Артамонова, Т.В. (2008), Гендерные проявления личности в спорте, Волгоград.

2. Артамонова, Т.В., Шевченко, Т.А. (2009), Гендерная идентификация в спорте, Волгоград.

3. Бендас, Т.В. (2006), Гендерная психология. Учебное пособие, СПб.

4. Бугаевский, К.А. (2017), "Изучение показателей гендерной идентификации у девушек-спортсменок", Актуальные научные исследования в современном мире, № 29, С. 144-153.

5. Ворожбитова, А.Л. (2007), "Гендерная теория физической культуры как основа формирования гендерного сознания спортсменов", Вестник Ставропольского государственного университета, № 49, С. 27-31.

6. Джурмий, Д.И. (2015), "Особенности гендерной идентификации в спортивной деятельности", Проблемы совершенствования физической культуры, спорта и олимпизма, С. 169-174

7. Ильин, Е.П. (2003), Дифференциальная психология мужчины и женщины, СПб.

8. Ильин Е.П. (2010), Пол и гендер, СПб.

9. Ковалёва, В.В., Кодацких, И.Ю. (2017), "Особенности гендерных стереотипов студенческой молодёжи", Территория науки, № 2, C. $31-35$

10. Основи теорії гендеру: навчальний посібник (2004), Київ.

11. Тарасевич, Е.А. (2016), "Гендерные отличия спортсменов в различных классификационных группах видов спорта и спортивных ддисциплин", Слобожанський науково-спортивний вісник, № 2 (52), С. 117-120.

12. Тарасевич, Е.А., Камаев, О.И. (2018), "Гендерные различия в оценке роли занятий спортом как один из показателей качества жизни спортсменов", Фізична активність і якість життя людини. Збірник тез доповідей II міжнародної науково-практичної конференції, Східноєвроп. нац. ун-т імені Лесі Українки, Луцьк, С. 71.

13. Тарасевич, О.А., Камаєв, О.І. (2019), "Особливості гендерних відмінностей у спортсменів, що займаються спортивними єдиноборствами", Единоборства, № 4 (14), С. 117-26.

14. Цикунова, Н. Г. (2003), Гендерные характеристики личности спортсменов в маскулинных и фемининных видах спорта. Дис. канд. пед. наук, СПб., 181 с.

15. Шахов, Ш.К., Дамадаева, А.С. (2011), "Спорт как фактор формирования психологического пола личности", Теория и методи- 


\section{SLOBOZANS'KIJ NAUKOVO-SPORTIVNIJ VISNIK}

ка спорта висших дострижений, С. 16-18.

16. Bem, S.L. (1979), "Theory and measurement of androgyny", Journal of Personal and Social Psychology, Vol. 37, pp. 1047-1054

17. Bem, S.L. (1983), "Gender schema theory and its implications for child development: Raising gender-schematic children in a genderschematic society", Journal of women in culture and society, Vol. 8, No. 4, pp. 65-78.

18. Colker, R. (1980), "Correlates of female athletic: masculinity, femininity, selfesteem and attitudes toward women", Sex Roles, Vol. 6 , pp. 47-58.

19. Matteo, S. (1986), "The effect of sex and gender-schematic processing on sport participation. Sex Roles", Vol. 15, pp. 356-371.

20. Social groups and identities: developing the legacy of Henri Tajfel (1996), W. Peter Robinson (Ed.), Butterworth-Heinemann, Oxford.

21. Volpato, Ch. \& Contarello, A. (1999), "Towards a social psychology of extreme situations: Primo Levi's If This is a Man and social identity theory", European Journal of Social Psychology, Vol. 29, pp. 239-258.

Стаття надійшла до редакції: 27.10.2019 р.

Опубліковано: 30.12.2019 р.

Аннотация. Олег Камаев, Елена Тарасевич, Дарья Окунь. Гендерная идентификация спортсменов разной квалификации относительно классификационных групп видов спорта. Цель: определить гендерные типы спортсменов разной квалификации с учётом пола и в зависимости от классификационных групп видов спорта. Материал и методы: в исследовании принимали участие 859 студентов и студенток в возрасте от 17 до 28 лет, которые обучаются в Харьковской государственной академии физической культуры, Национальном университете физического воспитания и спорта Украины и в Сумском государственном педагогическом университете имени А. С. Макаренко, специализирующиеся в олимпийских и неолимпийских видах спорта и имеющие различную спортивную квалификацию. Из них 428 спортсменок и 431 спортсмен. Использованы такие методы исследования, как: анализ и обобщение литературных источников и Интернет-ресурсов по исследуемой проблеме; анкетирование; беседа; психологические методы: методика С. Бэм "Маскулинность / фемининность"; методы математической статистики. Результаты: выявлено процентное соотношение маскулинных, фемининных и андрогинных типов личности среди 859 исследуемых спортсменов и спортсменок, которые специализируются в спортивных играх и единоборствах, в циклических, скоростно-силовых и сложнокоординационных видах спорта. С маскулинным типом личности выявлено 238 юношей, что составляет 55\% от общего количества спортсменов и 238 девушек (56\% от их общего количества). Спортсменов андрогинного типа выявлено 193 человека (45\%), а спортсменок - 190 (44\%). Личностей фемининного типа ни среди юношей, ни среди девушек выявлено не было. Также определено процентное соотношение маскулинных и андрогинных спортсменов и спортсменок в разных классификационных группах видов спорта и спортивных дисциплинах относительно их биологического пола и спортивной квалификации. Выводы: относительно такого понятия, как "гендер", мужчины и женщины относятся к одному из трёх социокультурных полов: маскулинному, фемининному или андрогинному. Представление о мужественности (маскулинности) и женственности (фемининности) связаны не с биологическим полом человека, а с типом культуры, к которому он принадлежит. Спорт, как институт социализации, активно способствует формированию гендерных качеств личности. В результате исследования доказано, что соотношение гендерных типов и у мужчин, и у женщин изменяется в зависимости от вида спортивной деятельности, которой они занимаются. Высокая квалификация спортсменов и спортсменок способствует формированию у них маскулинности.

Ключевые слова: гендер, мужчины, женщины, маскулинность, фемининность, андрогинность, гендерная идентичность.

Abstract. Olena Tarasevich, Oleg Kamaev \& Daria Okun. Gender identification of athletes of different qualifications regarding classification groups of sports. Purpose: identify (determine) gender types of athletes of different qualifications depending on the classification groups of sports. Material \& Methods: the study involved 859 students from 17 to 28 years old, who study at the Kharkiv State Academy of Physical Culture, the National University of Physical Education and Sports of Ukraine and the Sumy State Pedagogical University named after A. S. Makarenko, specializing in Olympic and non-Olympic sports and with various sports qualifications. Of these, 428 male athletes and 431 female athletes. Such research methods were used as: analysis and generalization of literary sources and Internet resources on the investigated problem; questioning; conversation; psychological methods: S. Bem's technique "Masculinity / femininity"; methods of mathematical statistics. Results: the percentage correlation of masculine, feminine and androgynous types of personality was revealed among 859 male and female athletes studied, who specialize in sports games and martial arts, in cyclic, speed-strength and complex coordination sports. With a masculine personality type, 238 young men were identified, which is $55 \%$ of the total number of athletes and 238 girls (56\% of their total number). Athletes of the androgynous type identified 193 people (45\%), and athletes - 190 (44\%). Feminine-type personalities were not found among either boys or girls. The percentage ratio of masculine and androgynous male and female athletes in different classification groups of sports and sports disciplines relative to their biological gender and sports qualification is also determined. Conclusions: regarding such a concept as "gender", men and women belong to one of three sociocultural sexes: masculine, feminine, and androgenic. The idea of masculinity and femininity is associated not with the biological sex of a person, but with the type of culture to which he belongs. Sport, as an institute of socialization, actively contributes to the formation of gender qualities of an individual. As a result of the study, it was proved that the ratio of gender types in both men and women varies depending on the type of sports activity that they are engaged in. High qualification of athletes and athletes contributes to the formation of masculinity in them.

Keywords: gender, men, women, masculinity, femininity, androgyny, gender identity.

\section{References} Russ.)

1. Artamonova, T.V. (2008), Gendernye proyavleniya lichnosti v sporte [Gender manifestations of personality in sports], Volgograd. (in

2. Artamonova, T.V. \& Shevchenko, T.A. (2009), Gendernaya identifikatsiya v sporte [Gender Identification in Sports], Volgograd. (in Russ.)

3. Bendas, T.V. (2006), Gendernaya psikhologiya. Uchebnoe posobie [Gender Psychology], St. Petersburg. (in Russ.)

4. Bugaevskiy, K.A. (2017), "The Study of Gender Identification Indicators in Female Athletes", Aktualnye nauchnye issledovaniya $v$ sovremennom mire, No. 29, pp. 144-153. (in Russ.)

5. Vorozhbitova, A.L. (2007), "The Gender Theory of Physical Culture as the Basis for the Formation of the Gender Consciousness of Athletes", Vestnik Stavropolskogo gosudarstvennogo universiteta, No. 49, pp. 27-31. (in Russ.)

6. Dzhurmiy, D.I. (2015), "Features of Gender Identification in Sports Activities", Problemy sovershenstvovaniya fizicheskoy kultury, sporta i olimpizma, pp. 169-174. (in Russ.)

7. Ilin, Ye.P. (2003), Differentsialnaya psikhologiya muzhchiny i zhenshchiny [Differential Psychology of Men and Women], St. Petersburg. (in Russ.)

8. Ilin Ye.P. (2010), Pol i gender [Sex and gender], St. Petersburg. (in Russ.) Russ.)

9. Kovaleva, V.V. \& Kodatskikh, I.Yu. (2017), "Features of the gender stereotypes of student youth", Territoriya nauki, No. 2, pp. 31-35. (in

Тарасевич, О., Камаєв, О., Окунь, Д. (2019), "Гендерна ідентифікація спортсменів різної кваліфікації відносно класифікаційних груп видів спорту", Слобожанський науково-спортивний вісник, № 6(74), С. 10-15, doi:10.15391/snsv.2019-6.002

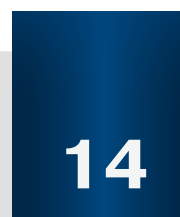

Tarasevich, O., Kamaev, O. \& Okun, D. (2019), "Gende identification of athletes of different qualifications regarding classification groups of sports", Slobozans kij naukovo-sportivn visnik, No. 6(74), pp. 10-15, doi:10.15391/snsv.2019-6.002 


\section{СЛОБОЖАНСЬКИЙ НАУКОВО-СПОРТИВНИЙ ВІСНИК}

10. Osnovy teorii genderu: navchalniy posibnik [Fundamentals of Gender Theory] (2004), Kyiv. (in Ukr.)

11. Tarasevich, Ye.A. (2016), "Gender differences of athletes in various classification groups of sports and sports disciplines", Slobozans 'kij naukovo-sportivnij visnik, No. 2 (52), pp. 117-120. (in Russ.)

12. Tarasevich, Ye.A. \& Kamaev, O.I. (2018), "Gender differences in assessing the role of playing sports as one of the indicators of the quality of life of athletes", Fizichna aktivnist $i$ yakist zhittya lyudini. Zbirnik tez dopovidey II mizhnarodnoi naukovo-praktichnoi konferentsii, Eastern Europe. nat. Lesya Ukrainka University, Lutsk, p. 71. (in Russ.)

13. Tarasevich, O.A. \& Kama€v, O.I. (2019), "Peculiarities of Gender Differences in Martial Arts Athletes", Yedinoborstva, No. 4 (14), pp. 117-26. (in Ukr.)

14. Tsikunova, N.G. (2003), Gendernye kharakteristiki lichnosti sportsmenov v maskulinnykh i femininnykh vidakh sporta. Dis. kand. ped. nauk [Gender characteristics of the personality of athletes in masculine and feminine sports: PhD Dis.], St. Petersburg, 181 p. (in Russ.)

15. Shakhov, Sh.K. \& Damadaeva, A.S. (2011), "Sport as a factor in the formation of the psychological gender of a person", Teoriya $i$ metodika sporta visshikh dostrizheniy, pp. 16-18. (in Russ.)

16. Bem, S.L. (1979), "Theory and measurement of androgyny", Journal of Personal and Social Psychology, Vol. 37, pp. 1047-1054.

17. Bem, S.L. (1983), "Gender schema theory and its implications for child development: Raising gender-schematic children in a genderschematic society", Journal of women in culture and society, Vol. 8, No. 4, pp. 65-78.

18. Colker, R. (1980), "Correlates of female athletic: masculinity, femininity, selfesteem and attitudes toward women", Sex Roles, Vol. 6 , pp. 47-58.

19. Matteo, S. (1986), "The effect of sex and gender-schematic processing on sport participation. Sex Roles", Vol. 15, pp. 356-371

20. Social groups and identities: developing the legacy of Henri Tajfel (1996), W. Peter Robinson (Ed.), Butterworth-Heinemann, Oxford.

21. Volpato, Ch. \& Contarello, A. (1999), "Towards a social psychology of extreme situations: Primo Levi's If This is a Man and social identity theory", European Journal of Social Psychology, Vol. 29, pp. 239-258.

Received: 27.10.2019.

Published: 30.12 .2019 .

\section{Відомості про авторів / Information about the Authors}

Тарасевич Олена Анатоліївна: старший викладач кафедри олімпійського і професійного спорту; Харківська державна академія фізичної культури: вул. Клочківська, 99, м. Харків, 61058, Україна.

Тарасевич Елена Анатольевна: старший преподаватель кафедры олимпийского и профессионального спорта; Харьковская государственная академия физической культуры: ул. Клочковская, 99, г. Харьков, 61058, Украина.

Olena Tarasevich: Senior Lecturer of the Department of Olympic and Professional Sports; Kharkiv State Academy of Physical Culture: Klochkovskaya st., 99, Kharkov, 61058, Ukraine.

ORCID.ORG/0000-0002-6016-3608

E-mail: tarasevichelena13@gmail.com

Камаєв Олег Іванович: д. фіз. вих., професор; Харківська державна академія фізичної культури: вул. Клочківська 99, м. Харків, 61058, Україна.

Камаев Олег Иванович: д. физ. восп., профессор; Харьковская государственная академия физической культуры: ул. Клочковская 99, г. Харьков, 61058, Украина.

Oleg Kamaev: Doctor of Science (Physical Education and Sport), Professor; Kharkiv State Academy of Physical Culture: Klochkivska 99, Kharkiv, 61058, Ukraine.

ORCID.ORG/0000-0003-4358-888X

E-mail: oips.hdafk@gmail.com

Окунь Дар'я Олександрівна: кандидат наук з фізичного виховання і спорту, викладач кафедри олімпійського і професійного спорту, Харківська державна академія фізичної культури, 61058, м. Харків, вул. Клочківська, 99.

Окунь Дарья Александровна: кандидат наук по физическому воспитанию и спорту, преподаватель кафедры олимпийского и профессионального спорта, Харьковская государственная академия физической культуры, 61058, г. Харьков, ул. Клочковская, 99.

Daria Okun: Phd (Physical Education and Sport), Lecturer in the Department of Olympic and Professional Sports, Kharkov State Academy of Physical Culture, 61058, Kharkiv, st. Klochkovskaya, 99.

ORCID.ORG/0000-0002-0639-5846

E-mail: dariaokun@gmail.com 


\section{Стратегія самоменеджменту у навчальних програмах для пацієнтів із хронічним обструктивним захворюванням легень}

\author{
Катерина Тимрук-Скоропад' \\ Юлія Павлова' \\ Надія Сидорик ${ }^{2}$
}

${ }^{1}$ Львівський державний університет фізичної культури імені Івана Боберського, Львів, Україна

${ }^{2}$ Некомерційне комунальне підприємство "5 Міська клінічна лікарня", Медичний центр "Медікавер",

Львів, Україна

Мета сучасної терапії хронічного обструктивного захворювання легень (ХОзЛ) - зменшити вираженість симптомів і попередити розвиток рецидивів загострення, зберегти легеневу функцію на оптимальному рівні та підвищити якість життя пацієнтів. Вирішенню перелічених проблем служить легенева реабілітація. Пошук ефективних шляхів надання освітнього компоненту, оцінювання впливу різних програм навчання та впровадження стратегії самоврядування продовжуються.

Мета: проаналізувати сучасні підходи, переваги та недоліки освітніх програм з питань самоменеджменту осіб з Хозл та встановити роль фахівця фізичної терапії у їх забезпеченні.

Матеріал і методи: пошук проводили на ресурсі Національного центру біотехнологічної інформації США РиbМед та у базі науково-доказової літератури з фізичної терапії PEDro. За результатами пошуку в базах отримано З29 посилання, із яких після виключення тих, які не відповідали необхідним критеріям, для аналізу відібрано 14 публікацій.

Результати: виявлено 29 навчальних тем, які стосуються освіти з питань самоменеджменту та у різній комбінації рекомендуються для вивчення у навчальних програмах для пацієнтів із ХОЗЛ. Навчальні теми згруповано у чотири навчальні модулі, які враховують мету та завдання стратегії самоменеджменту й забезпечують їх вирішення. Найбільш часто компетентними у реалізації освітніх програм для пацієнтів із ХОЗл зазначаються пульмонолог, фізичний терапевт, медсестра, фармацевт, ерготерапевт, соціальний працівник. Проаналізовано зміст, результати, переваги та обмеження різних навчальних програм із самоменеджменту.

Висновки: на сьогодні є недостатньо практичних рекомендацій та чітких критеріїв, яким повинні відповідати навчальні програми із самоменеджменту для пацієнтів із ХОЗЛ. Аналіз сучасних клінічних досліджень, присвячених впровадженню навчання із самоменеджменту є підгрунтям для розробки україномовних навчальних програм.

Ключові слова: фізичний терапевт, фізична терапія, легенева реабілітація, освіта, ХОЗЛ, самоконтроль.

\section{Вступ}

Для пацієнта важливо розуміти особливості свого захворювання, наявні можливості його лікування та контролю. У випадку хронічного захворювання, що вимагає постійного лікування та реабілітації, значних зусиль та постійних заходів, щоб попередити погіршення, такі знання $€$ життєво необхідними. Реалізація комплексного підходу у легеневій реабілітації пацієнтів із хронічним обструктивним захворюванням легень (ХОЗЛ) передбачає реалізацію освітнього компоненту, саме в його межах пацієнту допомагають сформувати та розвинути навички, які $є$ підґрунтям ефективного самоменеджменту [36].

Перша публікація, яка була опублікована в 1986 році, була близька до питань самоменеджменту та присвячена самоконтролю та управлінню стресом у пацієнтів із хронічними захворюваннями, зокрема, з ХОЗЛ [1]. На сьогодні увага науковців та фахівців з легеневої реабілітації значно частіше зосереджена на проблемах самоменеджменту пацієнтів, оцінюванні його переваг та ефективності, зокрема, у комплексі з іншими компонентами програм легеневої реабілітації.

Втручання щодо реалізації самоменеджменту для людей із ХОЗЛ мають певну структуру, є персоналізованими та часто багатокомпонентними. Вони мають за мету мотивувати, залучати та підтримувати пацієнтів у процесі адаптування поведінки та розвитку навичок кращого управління хворобою [14].

Концепція самоменеджменту містить самоконтроль, управління симптомами, емоційними, психосоціальними й функціональними наслідками захворювання, передбачає співпрацю із сім'єю, громадою та медичними працівниками [32].

Стратегія самоменеджменту, яка відокремилася 3 освітнього компоненту, на сьогодні є більш комплексною, охоплює ширше коло завдань, ставить за мету підвищення рівня самоефективності та контролю захворювання, спираючись на високий рівень знань пацієнта, добре сформовані навички, налагоджену співпрацю з фахівцями охорони здоров'я [35].

Підходи, спрямовані на розвиток самоменеджменту у першу чергу ґрунтуються на наданні пацієнтам необхідної інформації, а також формулюванні індивідуальної мети і стратегії, зосереджуються на підтримці мотивації, досягнень та високого рівня психічного здоров'я [8].

В Україні освіта пацієнтів з ХОЗЛ та їх інформування щодо хвороби, зміни способу, необхідних щоденних дій, безсумнівно присутня у процесі лікування та реабілітації. Однак така просвіта є не системною, відсутнє дидактичне та методичне забезпечення. Зазвичай, неврахованими $€$ рекомендації провідних професійних товариств та клінічні настанови, до командної та взаємозв'язаної роботи не залучають фахівців різних спеціальностей. Проте бездумне копіювання провідних світових підходів для реабілітації та освіти пацієнтів із ХОЗЛ в Україні не видається можливим та доцільним. Слід врахувати особливості української системи охорони здоров'я, матеріально-технічне та кадрове забезпечення, готовність пацієнтів витрачати додаткові 


\section{СЛОБОЖАНСЬКИЙ НАУКОВО-СПОРТИВНИЙ ВІСНИК}

ресурси на передбачені під час лікування та реабілітації заходи. Важливим кроком у впровадженні освітнього компоненту легеневої реабілітації та самоменеджменту, зокрема, із залученням фахівців фізичної терапії, $€$ аналіз сучасних підходів, переваг та недоліків наявних освітніх програм.

Метою дослідження було проаналізувати сучасні підходи, переваги та недоліки освітніх програм з питань самоменеджменту осіб з ХОЗЛ та встановити роль фахівця фізичної терапії у їх забезпеченні.

\section{Матеріал і методи дослідження}

Пошук проводили на ресурсі Національного центру біотехнологічної інформації США (National Center for Biotechnology Information) PubMed та у базі науково доказової літератури з фізичної терапії PEDro. Пошук у базах здійснено за низкою ключових слів (для PubMed "COPD", "Chronic Obstructive Pulmonary Disease", "Physical Therapy", "Physical Therapy", "Physiotherapy", "Selfmanagement", "Self management; для PEDro - "Chronic Obstructive Pulmonary Disease", "Self-management") з використанням булевих логічних операторів "AND" і "OR". нi:

Критеріями включення праць для аналізу були наступ-

1) публікація стосується питань самоменеджменту в осіб з ХОЗЛ;

2) наукова праця стосується значення, шляхів впровадження стратегії самоменеджменту, його ефективності та змістового наповнення як окремої діяльності, або частини програм легеневої реабілітації чи фізичної терапії; $2019 \mathrm{p}$

3) опубліковані впродовж червень 2014 р. - червень

Застосовували такі критерії виключення:

1) не відповідають обраному періоду пошуку -червень 2014 р. - червень 2019 р;

2) протоколи незавершених клінічних досліджень, пілотні дослідження, методологічні обґрунтування майбутніх клінічних досліджень;

3) публікації, які стосувалися інших захворювань дихальної системи, або якщо пацієнт одночасно мав ХОЗЛ та інше захворювання / інші захворювання;
4) дослідження присвячені використанню самоменеджменту під час фармакотерапії або для контролю психоемоційного стану;

5) відсутній доступ до повнотекстової статті;

6) мова публікації не $є$ англійською.

Пошук провели у червні 2019 р.

За результатами пошуку в базах отримано 329 посилання (рис. 1), зокрема, 232 - з бази PubMed та $97-3$ бази PEDro. На етапі скринінгу було виявлено дублювання посилань ( $n=19)$ та вилучено праці, які відповідали крите-

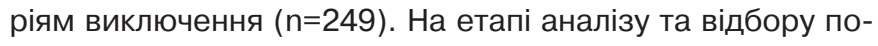
внотекстових статей додатково вилучено 47 публікацій, які відповідали критеріям виключення. Надалі у роботі аналізували зміст 14 публікацій, які відповідали усім вимогам пошуку.

\section{Результати дослідження}

За результатами аналізу 14 наукових праць виявлено 29 навчальних тем, які стосуються освіти з питань самоменеджменту та у різній комбінації рекомендуються для вивчення у навчальних програмах (табл. 1).

Навчальними модулями, які враховують мету та завдання стратегії самоменеджменту й забезпечують їх вирішення, $є$ :

- управління симптомами;

- самоконтроль;

- управління наслідками захворювання (емоційними, психосоціальними, функціональними);

- співпраця з сім'єю, громадою, фахівцями сфери охорони здоров'я.

До реалізації запропонованих навчальних тем залучають фахівців різних спеціальностей. Зокрема, найбільш часто компетентними у реалізації освітніх програм для пацієнтів із ХОЗЛ зазначаються пульмонолог, фізичний терапевт, медсестра, фармацевт, ерготерапевт, соціальний працівник. Навчальні теми, до викладу яких рекомендували залучати фізичних терапевтів, також зазначені в табл. 1.

Попри подібність компонентів освіти пацієнта і освіти 3 питань самоменеджменту вони мають низку важливих від-

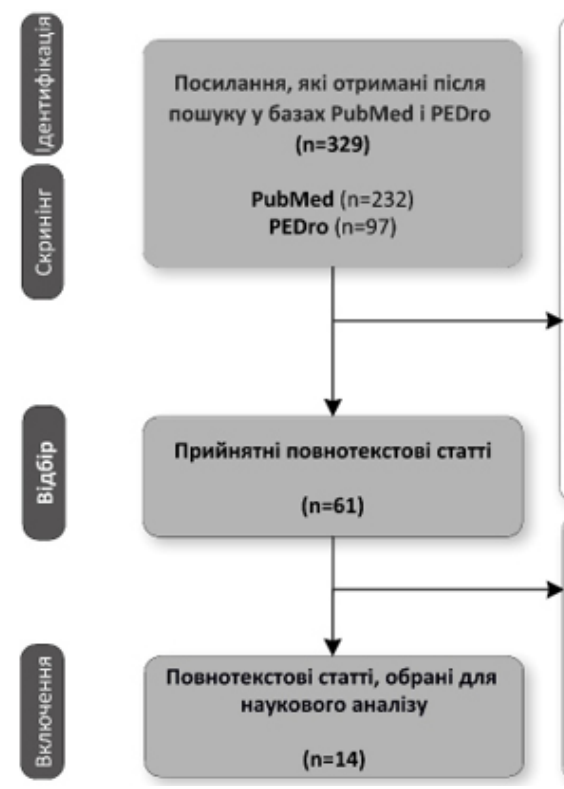

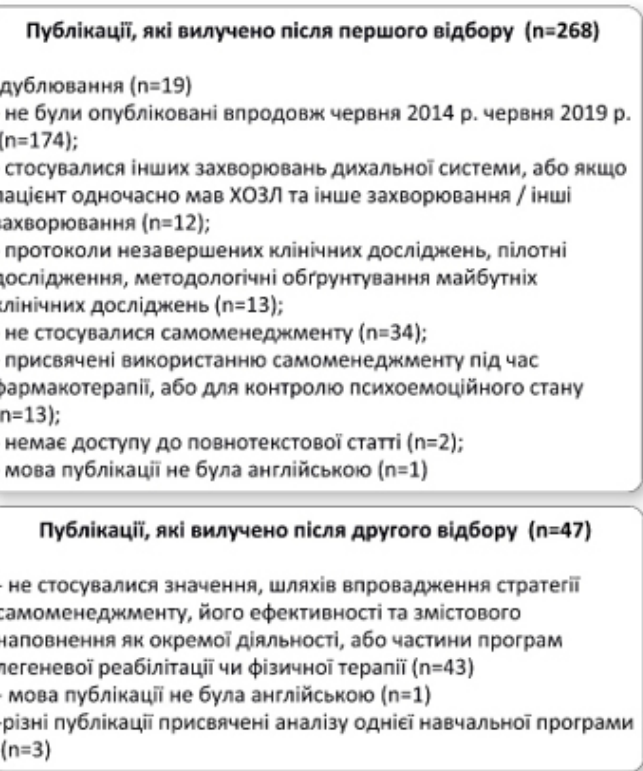

Pис. 1. Блок-схема PRISMA відбору публікацій для аналізу 


\section{SLOBOZANS'KIJ NAUKOVO-SPORTIVNIJ VISNIK}

Таблиця 1 Зміст освітніх програм з питань самоменеджменту

\begin{tabular}{|c|c|c|c|c|c|c|c|c|c|c|c|c|c|c|c|}
\hline \multirow{2}{*}{ Модуль } & \multirow{2}{*}{ Теми } & \multicolumn{14}{|c|}{ Наукова праця } \\
\hline & & 1 & 2 & 3 & 4 & 5 & 6 & 7 & 8 & 9 & 10 & 11 & 12 & 13 & 14 \\
\hline \multirow{6}{*}{$\begin{array}{c}\text { Управління } \\
\text { симптомами }\end{array}$} & $\begin{array}{l}\text { Захворювання легень і } \\
\text { лікування ХОЗЛ }\end{array}$ & + & + & + & $+\Phi$ & $+\Phi$ & H3 & + & + & - & - & H3 & - & + & + \\
\hline & Ліки & + & + & + & + & $+\Phi$ & + & - & + & + & + & + & - & + & - \\
\hline & Киснева терапія & + & + & - & - & - & H3 & - & H3 & - & - & - & - & - & - \\
\hline & $\begin{array}{l}\text { Контроль над } \\
\text { захворюванням } \\
\text { (зокрема, симптомами та } \\
\text { загостреннями) }\end{array}$ & + & + & \pm & $+\Phi$ & $+\Phi$ & + & + & + & - & + & + & - & + & + \\
\hline & Керування задишкою & $+\Phi$ & + & \pm & $+\Phi$ & $+\Phi$ & + & + & + & + & + & + & - & + & + \\
\hline & Очищення дихальних шляхів & $+\Phi$ & + & + & $\Phi$ & H3 & H3 & H3 & + & + & - & + & - & H3 & + \\
\hline \multirow{10}{*}{ Самоконтроль } & Тести респіраторної функції & + & + & - & - & - & H3 & - & - & + & + & - & - & - & - \\
\hline & $\begin{array}{l}\text { Ощадливе використання } \\
\text { власних сил }\end{array}$ & + & + & - & - & - & H3 & + & + & - & - & + & - & - & - \\
\hline & Харчування & + & + & + & + & $+\Phi$ & $\mathrm{H} 3$ & + & + & - & - & - & - & - & - \\
\hline & $\begin{array}{l}\text { Визначення власної мети, } \\
\text { завдань, плану дій }\end{array}$ & - & + & - & + & - & H3 & - & + & - & + & + & + & - & - \\
\hline & Спосіб життя (звички) & - & - & - & - & $+\Phi$ & + & + & + & - & + & + & + & - & + \\
\hline & $\begin{array}{l}\text { Практичні навички } \\
\text { користування інгаляторами }\end{array}$ & - & - & - & - & - & - & - & - & + & + & - & - & - & - \\
\hline & Обмеження і ХОЗЛ & $+\Phi$ & + & \pm & - & - & - & - & - & - & - & - & + & H3 & + \\
\hline & Подорожі & - & + & - & - & - & - & - & - & - & - & - & - & - & - \\
\hline & Вільний час та хобі & - & + & - & - & $+\Phi$ & - & - & - & - & - & + & - & - & - \\
\hline & $\begin{array}{l}\text { Визначення швидкості } \\
\text { ходьби }\end{array}$ & - & + & - & - & - & - & - & - & - & - & - & - & - & - \\
\hline \multirow{7}{*}{$\begin{array}{c}\text { Управління } \\
\text { наслідками } \\
\text { захворювання } \\
\text { (емоційними, } \\
\text { психосоціальними, } \\
\text { функціональними) }\end{array}$} & Фізичні вправи і активність & $+\Phi$ & + & + & $+\Phi$ & $+\Phi$ & + & + & + & + & + & + & + & + & + \\
\hline & Стрес і тривога & + & + & - & + & $+\Phi$ & + & + & + & - & - & + & - & + & + \\
\hline & $\begin{array}{l}\text { Управління когнітивними } \\
\text { Функціями }\end{array}$ & - & - & - & + & - & H3 & - & - & - & - & - & - & - & - \\
\hline & $\mathrm{COH}$ & - & - & - & - & $+\Phi$ & - & $\mathrm{H} 3$ & - & - & - & - & - & - & - \\
\hline & Релаксація & - & - & - & - & - & - & - & - & - & - & - & - & - & + \\
\hline & Ковтання та ХОЗЛ & + & - & - & - & - & - & - & - & - & - & - & - & - & - \\
\hline & Скринінг ковтання & + & - & - & - & - & - & - & - & - & - & - & - & - & - \\
\hline \multirow{6}{*}{$\begin{array}{c}\text { Життя у родині, } \\
\text { співпраця з } \\
\text { громадою, } \\
\text { фахівцями сфери } \\
\text { охорони здоров'я }\end{array}$} & Ресурси, які надає громада & + & - & - & + & - & + & - & - & - & - & - & - & - & - \\
\hline & Допомога опікунам & - & + & - & - & - & - & - & - & - & - & - & - & - & - \\
\hline & Стосунки & - & + & - & - & - & - & - & - & - & - & - & - & - & - \\
\hline & Сексуальність і інтимність & + & + & - & - & $+\Phi$ & H3 & - & - & - & - & - & - & - & - \\
\hline & Комунікація & - & - & - & + & - & $\mathrm{H} 3$ & - & - & - & - & - & - & - & - \\
\hline & $\begin{array}{l}\text { Вплив партнера, сім'ї, друзів } \\
\text { та колег на поведінку }\end{array}$ & - & - & - & - & - & - & - & - & - & - & - & + & + & - \\
\hline
\end{tabular}

Примітки: 1-Blackstock, F. C. [4]; 2-Chaplin, E. [1; 11]; 3-Blбnquez Moreno, C. et al. [5]; 4-Cameron-Tucker, H. L. [9]; 5-Carron, T. [10]; 6 - Chen, K. H. et al. [12]; 7-Lopez-Lopez, L. et al. [23]; 8-Nyberg, A. et al. [30]; 9-Bhattacharyya, P. et al. [3]; $10-$ Jolly, K. et передбачено проводити фізичному терапевту, НЗ - не зазначено; \pm - тема розкрита частково.

мінностей [7], а саме - освіта з питань самоменеджменту ґрунтується на прихильності пацієнта до запропонованої навчальної програми та його активній участі; проблеми мету та завдання формулює пацієнт, а не фахівець з охорони здоров'я; інформація, що надається, та формування навичок має проблемно-орієнтований, а не нозологічний характер; зміна поведінки відбувається внаслідок зростання впевненості пацієнта в можливості брати участь у самоменеджменті, а не лише внаслідок зростання рівня знань. Загалом освіта з питань самоменеджменту має за мету заохотити пацієнта контролювати захворювання та його наслідки [20]. Компонент "освіта пацієнта" у програмах легеневої реабілітації не є достатньо ефективним, оскільки не змінює у достатній мірі поведінку хворого, не дозволяє сформувати необхідні навички самодопомоги на високому рівні [31]. На думку Sohanpal, R. et al. [34], освіту пацієнта слід розглядати як частину компонента

\section{"освіта з питань самоменеджмента".}

Освіта з питань самоменеджменту спрямована на вирішення двох основних завдань: 1) корегувати поведінку пацієнта для подальшої підтримки здоров'я; 2) навчити пацієнтів, як впливати на захворювання та управляти ним.

Зміна поведінки пацієнта для підтримання його здоров'я передбачає збільшення рівня фізичної активності, виконання фізичних вправ, відмову від куріння, а також спрямована на підвищення прихильності хворого до медикаментозного лікування, опанування правильної методики інгаляцій.

Вплив на захворювання та управління ним передбачає наступне:

уникнення чинників, що погіршують стан пацієнта (куріння, пил);

керування задишкою (прийом медикаментів, опа-
Тимрук-Скоропад, К., Павлова, Ю., Сидорик, Н. (2019), "Стратегія самоменеджменту у навчальних програмах для пацієнтів із хронічним обструктивним захворюванням легень", Слобожанський науково-спортивний вісник, № 6(74), С. 16-24, doi:
$10.15391 /$ snsv.2019-6.003
Tymruk-Skoropad, K., Pavlova, lu. \& Sydoryk, N. (2019), "Selfmanagement strategy in training programs for patients with chronic obstructive pulmonary disease", Slobozans kij naukovosportivnij visnik, No. 6(74), pp. 16-24, doi:10.15391/snsv.2019
6.003 


\section{СЛОБОЖАНСЬКИЙ НАУКОВО-СПОРТИВНИЙ ВІСНИК}

нування техніки дихання через стиснуті губи);

використання методів ощадливого використання власних сил (наприклад, вибір темпу ходьби);

укладання стратегії управління загостренням (план дій, що містить ключові компоненти для полегшення керування загостренням);

використання технік керування стресом (вправи для розслаблення).

Освіта з питань самоменеджменту для осіб з ХОЗЛ спрямована на опанування таких груп навичок [13]:

запобігання, контролю та управління наслідками

ХОЗЛ та респіраторними симптомами;

контролю та управління щоденною активністю;

подолання проблем із сном;

контролю загострень та управління ними;

керування психічним станом та подолання емоційного дискомфорту;

керування соціальними сферами життя;

співпраці із закладами охорони здоров'я;

- самостійного догляду за собою.

Найбільш поширеними варіантами реалізації програми з питань самоменеджменту для пацієнтів з ХОЗЛ - очні заняття, веб-ресурси та друковані матеріали.

Kruijssen, V. et al [22] для ефективної реалізації освіти з питань самоменеджменту, оволодіння навичками самоконтролю, а також налагодження зворотного зв'язку з фахівцями охорони здоров'я рекомендує використовувати он-лайн щоденник. Пацієнти із ХОЗЛ, які використовували такий інструмент почували себе більш впевнено, відзначали, що ліпше контролюють власне захворювання; перешкодами щодо впровадження цієї методики у регулярну практику є низький рівень прихильності пацієнта та погані навички користування Інтернетом саме у цієї категорії хворих. Запропоновані підходи можуть мати низку перешкод під час впровадження в Україні - їх може бути складно реалізувати через вікові особливості хворих з ХОЗЛ, ї рівень Інтернет-грамотності, невміння користуватися мобільними і веб-додатками, проблеми з доступом до Інтернету. Також проблемою для українського пацієнта слід вважати обмежену кількість україномовних Інтернетресурсів, присвячених підтримці осіб із ХОЗЛ, розрахованих у першу чергу на пацієнта. Це обмежує можливість використання деяких варіантів навчальних матеріалів.

\section{Висновки / Дискусія}

Освіта з питань самоменеджменту надає низку переваг для осіб з ХОЗЛ -вона сприяє поліпшенню функціонального рівня та загалом стану здоров'я [27], допомагає зменшити показник госпіталізації, допомагає сформувати та надалі розвивати навички, що допомагають контролювати захворювання [29]

На думку пацієнтів із ХОЗЛ, самоменеджмент складний і мінливий процес, основними компонентами якого повинні бути саморегуляція і вибір відповідної здоров'язберігаючої поведінки [12]. На нього впливають тривалість захворювання та наявний досвід хвороби, психічний стан та соціальна підтримка. Відповідно, навчальні програми з питань самоменеджменту потрібно розробляти із врахуванням особливостей, досвіду та стану пацієнта. Інтерв'ювання пацієнтів виявило чотири основні, значні за обсягом тематики, у яких були зацікавлені пацієнти: стосунки із медичними працівниками, інформованість пацієнтів, підтримка і доступ до системи охорони здоров'я [2].

На сьогодні немає єдиної оцінки ефективності освітніх програм з питань самоменеджменту. Так, оцінювання таких програм виявило їх позитивний вплив на такі напрямки самоменеджменту як "Конструктивні установки та підходи", "Набуття навичок та техніки", "Самоконтроль та розуміння") [8], на поліпшення якості життя [17; 28], підвищення рівня знань про захворювання [26], зменшення показника госпіталізації, частоти відвідувань лікаря [33; 38], збільшення часу до першого загострення [17]. У когортному дослідженні Khan, A. et al. [21] пацієнти, які мали розроблений план самоменеджменту, частіше відвідували навчальний курс або консультації з фізичної активності, мали вищий рівень знань про ХОЗЛ і ліпшу прихильність до лікування. Натомість, у Harrison, S. L. [15] навчальні програми з питань самоменеджменту не впливали на показники якості життя, фізичну працездатність чи психоемоційний стан. Blackstock, F. C. [4] запропонував 8-тижневу програму, яка передбачала шістнадцять занять тривалістю 45 хв та складалася з фізичних вправ та навчальних модулів з питань самоменеджменту; ця програма не була більш ефективною для поліпшення якості життя та результатів 6-хвилинного тесту ходьби, порівняно з програмою, що складалася виключно з фізичних вправ. Учасники, які відвідували додаткові навчальні заняття мали вищий рівень знань про хворобу, ніж пацієнти, які лише виконували фізичні вправи, проте статистично достовірного зменшення кількості звернень до лікаря чи прийому медикаментів не спостерігали. Це дослідження виявило певні обмеження, пов'язані із організацією мультидисциплінарного підходу до реалізації експериментальної програми, зокрема, низьку прихильність пацієнтів до програми - лише $60 \%$ учасників прийняло у ній участь та відвідали 70\% запланованих занять. Стратегію самоменеджменту та відповідний освітній компонент можуть впроваджувати, реалізовувати і контролювати різні фахівці, які в межах своєї компетентності відповідають за свою частину навчального плану та подальшу підтримку пацієнта. У випадку програми Blackstock, F. C. [4], необхідність залучення фахівців десяти спеціальностей можна також віднести до недоліків програми. Подібні результати були отримані під час вивчення впливу освітньої веб-програми з питань самоменеджменту, недосягнутими залишилися основні цілі програми - збільшення фізичних навантажень та відмова від куріння / обмеження кількості викурених цигарок [37].

Blбnquez Moreno, C. et al. [5] запропонували коротшу за часом та меншу за обсягом навчальну програму. Це дозволило збільшити кількість пацієнтів, які завершили навчання (78,2\%). Зменшити тривалість освітньої програми вдалося за рахунок скорочення навчальних тем, які розглядали на заняттях. Окрім того, до навчання була залучена медична сестра. Такі рішення сприяли статистично достовірному поліпшенню рівня якості життя, результатів 6-хвилинного тесту ходьби та зменшенню задишки. Таким чином, якщо є обмеження щодо кадрового забезпечення, пацієнту важко відвідувати більше занять або сесії довшої тривалості, доцільно використовувати саме такий варіант навчальної програми, незважаючи на те, що мінімальна кількість сесій програми не відповідає рекомендаціям Британського торакального товариства [6].

Саме пошук оптимальної навчальної програми є причиною того, що відбувається апробація програм різних за тривалістю, обсягом, кількістю сеансів, змістовим напо- 


\section{SLOBOZANS'KIJ NAUKOVO-SPORTIVNIJ VISNIK}

вненням. Одним із варіантів реалізації програми було проведення навчання у таборах, які складалися із чотирьох інтенсивних днів з 6-тижневою перервою. Такій підхід, що мав доведену ефективність, дозволив організувати повноцінне оцінювання під час кожної зустрічі, повторювати вивчене, глибше засвоювати необхідний матеріал [3] Іншим варіантом реалізації навчальних програм самоменеджменту були спеціально організовані телефонні розмови, які попередньо узгоджували з пацієнтом [18]. Незважаючи на те, що такий підхід не дозволив поліпшити якість життя та фізичну працездатність пацієнта, порівняно із традиційними програмами легеневої реабілітації, було відзначено позитивні зміни у поведінці. Наприклад, збільшилася кількість пацієнтів, які мали рятувальні аптечки, зросла кількість запитів до лікарів перевірити техніку застосування інгалятора та погодити план дій при загостренні.

Ефективним $€$ використання друкованих матеріалів. Howard, С. використав брошуру, яка складалася з шістьох розділів. Такий підхід продемонстрував клінічну та економічну ефективність, був прийнятним для учасників, його можна застосовувати як на первинному, так і вторинному рівнях лікування [16]. Окрім того, друковані матеріали залишаються найбільш доступними для використання в Україні, де люди літнього віку мають обмежений доступ до сучасних Інтернет та комп'ютерних технологій та невисокий рівень знань, щоб їх використовувати.

На сьогодні програми на он-лайн платформах розглядають як доповнення до основної навчальної програми або альтернатива їй. Chaplin, E. et al. [11] показали високу прихильність пацієнтів до веб-програми навчання "SPACE for COPD", проте не виявили суттєвих відмінностей у результатах фізичної працездатності та якості життя, порівняно з класичною програмою легеневої реабілітації та ї освітнім компонентом. Подібні результати мала навчаль- на програми з питань самоменеджменту, розміщена на веб-платформі [30]. Прихильність осіб з ХОЗЛ до цієї програми і відвідуваність розробленого сайту становила 77\% від пацієнтів експериментальної групи; такий результат співмірний з рівнем прихильності пацієнтів до типового навчання.

Більшість навчальних програм із самоменеджменту $€$ частиною легеневої реабілітації, яку рекомендують розпочинати впродовж першого місяця після госпіталізації. Однак, за деякими даними [23], включення сесій із самоменеджменту для пацієнтів з ХОЗЛ, госпіталізованих через загострення, має позитивний вплив на якість життя та функціональні можливості, зокрема, ефективність впливу $€$ ліпша, порівняно лише із фізичною терапією.

Вивчення та практичне опанування самоменеджменту в рамках освітнього компоненту програм легеневої реабілітації є важливим для управління захворюванням та зменшення його впливу на життя, а відповідно підвищення якості життя пацієнтів із ХОЗЛ.

Пошук оптимальних варіантів реалізації навчальних програм самоменеджменту, їх змістового наповнення та тривалості потребує ґрунтовного аналізу та апробації. На сьогодні є недостатньо практичних рекомендацій та чітких критеріїв, яким критеріям повинні відповідати навчальні програми із самоменеджменту. Фахівці із фізичної терапії є активними розробниками навчальних програм та залучені до їх проведення.

За результатами аналізу сучасних наукових даних 3 питань самоменеджменту пацієнтів із ХОЗЛ виділено 29 окремих навчальних теми, які згруповано у 4 змістові модулі (управління симптомами; самоконтроль; управління наслідками захворювання; життя у родині, співпраця 3 громадою, фахівцями сфери охорони здоров'я) та виокремлено 3 основні варіанти їх реалізації (очні заняття, веб-ресурси та друковані матеріали).

Конфлікт інтересів. Автори заявляють, що немає конфлікту інтересів, який може сприйматися таким, що може завдати шкоди неупередженості статті. Джерела фінансування. Ця стаття не отримала фінансової підтримки від державної, громадської або комерційної організацій.

\section{Список посилань}

1. Apps, L.D. et al. (2013), "The development and pilot testing of the Self-management Programme of Activity, Coping and Education for Chronic Obstructive Pulmonary Disease (SPACE for COPD)", International Journal of COPD, (8), pp. 317-327, https://doi.org/10.2147/COPD. S40414.

2. Benzo, R.P. et al. (2017), "Health Coaching in Severe COPD After a Hospitalization: A Qualitative Analysis of a Large Randomized Study", Respiratory care. United States, 62(11), pp. 1403-1411, https://doi.org/10.4187/respcare.05574.

3. Bhattacharyya, P. et al. (2018), "The impact on health status in short- and long-terms of a novel and non-orthodox real-world COPD rehabilitation effort in rural India: an appraisal", International journal of chronic obstructive pulmonary disease. Dove Press, (13), pp. 33133319, https://doi.org/10.2147/COPD.S160665.

4. Blackstock, F.C. et al. (2014), "Comparable improvements achieved in chronic obstructive pulmonary disease through pulmonary rehabilitation with and without a structured educational intervention: A randomized controlled trial", Respirology. John Wiley \& Sons, Ltd (10.1111), 19(2), pp. 193-202, https://doi.org/10.1111/resp.12203.

5. BІбnquez Moreno, C. et al. (2018), "Effectiveness of an educational program for respiratory rehabilitation of Chronic Obstructive Pulmonary Disease patients in Primary Care in improving the quality of life, symptoms, and clinical risk", Atencion Primaria, 50(9), pp. 539546, https://doi.org/10.1016/j.aprim.2017.03.019.

6. Bolton, C.E. et al. (2013) "BTS Guideline on Pulmonary Rehabilitation in Adults British", Thorax. Edited by B. T. S. P. R. G. Group, (68), pp. ii1-ii30, https://doi.org/10.1136/thoraxjnl-2013-203808.

7. Bourbeau, J., Lavoie, K.L. and Sedeno, M. (2015), "Comprehensive Self-Management Strategies", Seminars in Respiratoryand Critical Care Medicine, Thieme Medical Publishers, Inc., 36(4), pp. 630-638. https://doi.org/10.1055/s-0035-1556059.

8. Bringsvor, H.B. et al. (2018), "Effects of a COPD self-management support intervention: a randomized controlled trial", International journal of chronic obstructive pulmonary disease, (13), pp. 3677-3688, https://doi.org/10.2147/COPD.S181005.

9. Cameron-Tucker, H.L. et al. (2014), "Chronic disease self-management and exercise in COPD as pulmonary rehabilitation: a randomized controlled trial", International journal of chronic obstructive pulmonary disease, (9), pp. 513-23, https://doi.org/10.2147/COPD.S58478

10. Carron, T. et al. (2017), "Feasibility, acceptability and effectiveness of integrated care for COPD patients: a mixed methods evaluation of a pilot community-based programme", Swiss Medical Weekly, EMH Media, 147(w4950), https://doi.org/10.4414/smw.2017.14567.

11. Chaplin, E. et al. (2017), "Interactive web-based pulmonary rehabilitation programme: a randomised controlled feasibility trial", BMJ 


\section{СЛОБОЖАНСЬКИЙ НАУКОВО-СПОРТИВНИЙ ВІСНИК}

open, BMJ Publishing Group, 7(3), p. e013682, https://doi.org/10.1136/bmjopen-2016-013682

12. Chen, K.-H. et al. (2016), "Living With Chronic Obstructive Pulmonary Disease: The Process of Self-Managing Chronic Obstructive Pulmonary Disease", The journal of nursing research, JNR, China, 24(3), pp. 262-271, https://doi.org/10.1097/jnr.0000000000000152.

13. Clari, M. et al. (2017), "Self-Care of People with Chronic Obstructive Pulmonary Disease: A Meta-Synthesis", The Patient - PatientCentered Outcomes Research, Springer International Publishing, 10(4), pp. 407-427.

14. Global Initiative for Chronic Obstructive Lung Disease - Global Initiative for Chronic Obstructive Lung Disease - GOLD (2017), available at: https://goldcopd.org/ (Accessed: 21 June 2019).

15. Harrison, S.L. et al. (2015), "Self-management following an acute exacerbation of COPD: A systematic review", Chest, 147(3), pp. 646-61, https://doi.org/10.1378/chest.14-1658

16. Howard, C. \& Dupont, S. (2014), "'The COPD breathlessness manual": a randomised controlled trial to test a cognitive-behavioural manual versus information booklets on health service use, mood and health status, in patients with chronic obstructive pulmonary disease", NPJ Prim care Respir Med., (24), p. 14076, https://doi.org/10.1038/npjpcrm.2014.76.

17. Johnson-Warrington, V. et al. (2016), "Can a supported self-management program for COPD upon hospital discharge reduce readmissions? A randomized controlled trial", International journal of chronic obstructive pulmonary disease, (11), pp. 1161-9, https://doi. org/10.2147/COPD.S91253.

18. Jolly, K. et al. (2018), "Self management of patients with mild COPD in primary care: Randomised controlled trial", BMJ (Online), BMJ Publishing Group, (361), https://doi.org/10.1136/bmj.k2241.

19. Jonsdottir, H. et al. (2015), "Effectiveness of a partnership-based self-management programme for patients with mild and moderate chronic obstructive pulmonary disease: a pragmatic randomized controlled trial", Journal of advanced nursing. England, 71(11), pp. 26342649, https://doi.org/10.1111/jan.12728.

20. Kaptein, A., Fischer, M. \& Scharloo, M. (2014), "Self-management in patients with COPD: theoretical context, content, outcomes, and integration into clinical care", International Journal of Chronic Obstructive Pulmonary Disease, 9(1), p. 907, https://doi.org/10.2147/COPD. S49622.

21. Khan, A. et al. (2017), "Self-management behaviour and support among primary care COPD patients: cross-sectional analysis of data from the Birmingham Chronic Obstructive Pulmonary Disease Cohort", NPJ Primary Care Respiratory Medicine. Nature Publishing Group, 27(1), p. 46, https://doi.org/10.1038/s41533-017-0046-6.

22. Lopez-Lopez, L. et al. (2019), "Results on health-related quality of life and functionality of a patient-centered self-management program in hospitalized COPD: a randomized control trial", Disability and rehabilitation, England, pp. 1-9, https://doi.org/10.1080/09638288 .2019 .1609099

23. Mandel, A.R. \& Keller, S.M. (1986), "Stress management in rehabilitation", Archives of physical medicine and rehabilitation, 67(6), pp. 375-9.

24. Marquis, N. et al. (2014), "Are improvements maintained after in-home pulmonary telerehabilitation for patients with chronic obstructive pulmonary disease?", International journal of telerehabilitation. University Library Systems, University of Pittsburgh, 6(2), pp. 2130. https://doi.org/10.5195/ijt.2014.6156.

25. Mitchell, K.E. et al. (2014), "A self-management programme for COPD: a randomised controlled trial", The European respiratory journal, European Respiratory Society, 44(6), pp. 1538-47, https://doi.org/10.1183/09031936.00047814.

26. Murphy, L.A. et al. (2017), "Clinical-effectiveness of self-management interventions in chronic obstructive pulmonary disease: An overview of reviews", Chronic Respiratory Disease. SAGE Publications Sage UK: London, England, 14(3), pp. 276-288, https://doi. org/10.1177/1479972316687208.

27. Newham, J.J. et al. (2017), "Features of self-management interventions for people with COPD associated with improved healthrelated quality of life and reduced emergency department visits: a systematic review and meta-analysis", International journal of chronic obstructive pulmonary disease, New Zealand, (12), pp. 1705-1720, https://doi.org/10.2147/COPD.S133317.

28. Ng, W.I. and Smith, G.D. (2017), "Effects of a self-management education program on self-efficacy in patients with COPD: a mixedmethods sequential explanatory designed study", International journal of chronic obstructive pulmonary disease, (12), pp. 2129-2139, https:// doi.org/10.2147/COPD.S136216.

29. Nyberg, A., Tistad, M. and Wadell, K. (2019), "Can the COPD web be used to promote self-management in patients with COPD in swedish primary care: a controlled pragmatic pilot trial with 3 month- and 12 month follow-up", Scandinavian Journal of Primary Health Care, Taylor and Francis Ltd, 37(1), pp. 69-82, https://doi.org/10.1080/02813432.2019.1569415.

30. Rice, K. et al. (2014), "Collaborative Self-Management and Behavioral Change", Clinics in Chest Medicine. Elsevier, 35(2), pp. 337351, https://doi.org/10.1016/J.CCM.2014.02.004.

31. Richard, A.A. and Shea, K. (2011), "Delineation of Self-Care and Associated Concepts", Journal of Nursing Scholarship, John Wiley \& Sons, Ltd (10.1111), 43(3), https://doi.org/10.1111/j.1547-5069.2011.01404.x.

32. Sanchez-Nieto, J.M. etal. (2016), "Efficacy of a self-management plan in exacerbations for patients with advanced COPD", International journal of chronic obstructive pulmonary disease, New Zealand, (11), pp. 1939-1947, https://doi.org/10.2147/COPD.S104728.

33. Sohanpal, R., Epiphaniou, E. and Taylor, S. (2014), "Self-management for COPD?: why does it generate negative connotations?", The British journal of general practice : the journal of the Royal College of General Practitioners. British Journal of General Practice, 64(625), pp. e522-4, https://doi.org/10.3399/bjgp14X681157.

34. Spruit, M.A. et al. (2013), "An Official American Thoracic Society/European Respiratory Society Statement: Key Concepts and Advances in Pulmonary Rehabilitation", American Journal of Respiratory and Critical Care Medicine, 43(5), pp. 1326-37, https://doi. org/10.1183/09031936.00145613.

35. Tymruk-Skoropad, K. et al. (2019), "Educational component in rehabilitation programs for persons with chronic obstructive pulmonary disease: a systematic review". Advances in Rehabilitation, (4).

36. van Kruijssen, V. et al. (2015), "Use of Online Self-Management Diaries in Asthma and COPD: A Qualitative Study of Subjects' and Professionals' Perceptions and Behaviors", Respiratory care. Respiratory Care, 60(8), pp. 1146-56, https://doi.org/10.4187/ respcare.03795.

37. Voncken-Brewster, V. et al. (2015), "A randomized controlled trial evaluating the effectiveness of a web-based, computer-tailored selfmanagement intervention for people with or at risk for COPD", International journal of chronic obstructive pulmonary disease, New Zealand, (10), pp. 1061-1073, https://doi.org/10.2147/COPD.S81295.

38. Wang, T. et al. (2017), "Effectiveness of disease-specific self-management education on health outcomes in patients with chronic obstructive pulmonary disease: an updated systematic review and meta-analysis [with consumer summary]", Patient Education and Counseling, 100(8). pp. 1432-1446, https://doi.org/10.1016/J.PEC.2017.02.026.

Стаття надійшла до редакції: 01.11.2019 р.

Опубліковано: 30.12.2019 р.

Аннотация. Екатерина Тимрук-Скоропад., Юлия Павлова, Надежда Сыдорык. Стратегия самоменеджмента в учебных программах для пациентов с хроническим обструктивным заболеванием легких. Цель современной терапии хронической обструктивной болезни легких (ХОБЛ) - уменьшить выраженность симптомов и предупредить развитие рецидивов обо-

Тимрук-Скоропад, К., Павлова, Ю., Сидорик, Н. (2019), "Стратегія самоменеджменту у навчальних програмах для пацієнтів із хронічним обструктивним захворюванням легень", Слобожанський науково-спортивний вісник, № 6(74), С. 16-24, doi 10.15391/snsv.2019-6.003
Tymruk-Skoropad, K., Pavlova, lu. \& Sydoryk, N. (2019), "Selfmanagement strategy in training programs for patients with chronic obstructive pulmonary disease", Slobozans kij naukovo sportivnij visnik, No. 6(74), pp. 16-24, doi:10.15391/snsv.2019
6.003 


\section{SLOBOZANS'KIJ NAUKOVO-SPORTIVNIJ VISNIK}

стрения, сохранить легочную функцию на оптимальном уровне и повысить качество жизни пациентов. Решению перечисленных проблем служит легочная реабилитация. Поиск эффективных путей предоставления образовательного компонента, оценивания влияния различных программ обучения и внедрение стратегии самоуправления продолжаются. Цель: проанализировать современные подходы, преимущества и недостатки образовательных программ по вопросам самоменеджмента лиц с ХОБЛ и установить роль специалиста физической терапии в их обеспечении. Материал и методы: поиск проводили на ресурсе Национального центра биотехнологической информации CША PubMed и в базе научно-доказательной литературы по физической терапии РЕDКо. По результатам поиска в базах получено 329 ссылок, из которых после исключения тех, которые не соответствовали необходимым критериям, для последующего анализа отобрано 14 публикаций. Результаты: выявлено 29 учебных тем, касающихся образования по вопросам самоменеджмента, которые в разной комбинации рекомендуются для изучения в учебных программах для пациентов с ХОБЛ. Учебные темы были сгруппированы в четыре учебные модули, учитывающие цели и задачи стратегии самоменеджмента и обеспечивающие их решение. Наиболее часто компетентными в реализации образовательных программ для пациентов с ХОБЛ указываются пульмонолог, физический терапевт, медсестра, фармацевт, эрготерапевт, социальный работник. Проанализированы содержание, результаты, преимущества и ограничения различных учебных программ по самоменеджменту. Выводы: на сегодня недостаточно практических рекомендаций и четких критериев, которым должны отвечать учебные программы по самоменеджменту для пациентов с ХОБЛ. Анализ современных клинических исследований, посвященных внедрению обучения с самоменеджмента, является основой для разработки украиноязычных учебных программ.

Ключевые слова: физический терапевт, физическая терапия, легочная реабилитация, образование, ХОБЛ, самоконтроль.

Abstract. Kateryna Tymruk-Skoropad, Iuliia Pavlova \& Nadiya Sydoryk. Self-management strategy in training programs for patients with chronic obstructive pulmonary disease. The aim of modern therapy for chronic obstructive pulmonary disease (COPD) is to reduce the severity of symptoms and prevent the development of relapse exacerbations, maintain pulmonary function at an optimal level and improve the quality of life of patients. The solution to these problems is pulmonary rehabilitation. Search for effective ways of providing an educational component, assessing the impact of various training programs and implementing a self-management strategy continues. Purpose: to analyze modern approaches, advantages and disadvantages of educational programs on self-management of people with COPD and establish the role of a physical therapy specialist in providing them. Material \& Methods: the search was conducted on the resource of the US National Center for Biotechnological Information PubMed and in the database of scientific evidence on physical therapy PEDro. According to the results of the search in the databases, 329 links were obtained, of which, after excluding those that did NOT meet the necessary criteria, 14 publications were selected for subsequent analysis. Results: 29 educational topics related to self-management education were identified, which in different combinations are recommended for study in educational programs for patients with COPD. Training topics were grouped into four training modules that took into account the goals and objectives of the self-management strategy and ensure their solution. The most often competent in implementing educational programs for patients with COPD are a pulmonologist, physical therapist, nurse, pharmacist, occupational therapist, and social worker. The content, results, advantages and limitations of various self-management training programs are analyzed. Conclusions: today there are not enough practical recommendations and clear criteria that training programs on self-management for patients with COPD should meet. The analysis of modern clinical studies on the introduction of self-management training is the basis for the development of Ukrainian-language training programs.

Keywords: physical therapist, physical therapy, pulmonary rehabilitation, education, COPD, self-control.

\section{References}

1. Apps, L.D. et al. (2013), "The development and pilot testing of the Self-management Programme of Activity, Coping and Education for Chronic Obstructive Pulmonary Disease (SPACE for COPD)", International Journal of COPD, (8), pp. 317-327, https://doi.org/10.2147/COPD. S40414.

2. Benzo, R.P. et al. (2017), "Health Coaching in Severe COPD After a Hospitalization: A Qualitative Analysis of a Large Randomized Study", Respiratory care. United States, 62(11), pp. 1403-1411, https://doi.org/10.4187/respcare.05574.

3. Bhattacharyya, P. et al. (2018), "The impact on health status in short- and long-terms of a novel and non-orthodox real-world COPD rehabilitation effort in rural India: an appraisal", International journal of chronic obstructive pulmonary disease. Dove Press, (13), pp. 33133319, https://doi.org/10.2147/COPD.S160665.

4. Blackstock, F.C. et al. (2014), "Comparable improvements achieved in chronic obstructive pulmonary disease through pulmonary rehabilitation with and without a structured educational intervention: A randomized controlled trial", Respirology. John Wiley \& Sons, Ltd (10.1111), 19(2), pp. 193-202, https://doi.org/10.1111/resp.12203.

5. Blбnquez Moreno, C. et al. (2018), "Effectiveness of an educational program for respiratory rehabilitation of Chronic Obstructive Pulmonary Disease patients in Primary Care in improving the quality of life, symptoms, and clinical risk", Atencion Primaria, 50(9), pp. 539546, https://doi.org/10.1016/j.aprim.2017.03.019.

6. Bolton, C.E. et al. (2013) "BTS Guideline on Pulmonary Rehabilitation in Adults British", Thorax. Edited by B. T. S. P. R. G. Group, (68), pp. ii1-ii30, https://doi.org/10.1136/thoraxjnl-2013-203808.

7. Bourbeau, J., Lavoie, K.L. and Sedeno, M. (2015), "Comprehensive Self-Management Strategies", Seminars in Respiratory and Critical Care Medicine, Thieme Medical Publishers, Inc., 36(4), pp. 630-638. https://doi.org/10.1055/s-0035-1556059.

8. Bringsvor, H.B. et al. (2018), "Effects of a COPD self-management support intervention: a randomized controlled trial", International journal of chronic obstructive pulmonary disease, (13), pp. 3677-3688, https://doi.org/10.2147/COPD.S181005.

9. Cameron-Tucker, H.L. et al. (2014), "Chronic disease self-management and exercise in COPD as pulmonary rehabilitation: a randomized controlled trial", International journal of chronic obstructive pulmonary disease, (9), pp. 513-23, https://doi.org/10.2147/COPD.S58478.

10. Carron, T. et al. (2017), "Feasibility, acceptability and effectiveness of integrated care for COPD patients: a mixed methods evaluation of a pilot community-based programme", Swiss Medical Weekly, EMH Media, 147(w4950), https://doi.org/10.4414/smw.2017.14567.

11. Chaplin, E. et al. (2017), "Interactive web-based pulmonary rehabilitation programme: a randomised controlled feasibility trial", BMJ open, BMJ Publishing Group, 7(3), p. e013682, https://doi.org/10.1136/bmjopen-2016-013682.

12. Chen, K.-H. et al. (2016), "Living With Chronic Obstructive Pulmonary Disease: The Process of Self-Managing Chronic Obstructive Pulmonary Disease", The journal of nursing research, JNR, China, 24(3), pp. 262-271, https://doi.org/10.1097/jnr.0000000000000152.

13. Clari, M. et al. (2017), "Self-Care of People with Chronic Obstructive Pulmonary Disease: A Meta-Synthesis", The Patient - PatientCentered Outcomes Research, Springer International Publishing, 10(4), pp. 407-427.

14. Global Initiative for Chronic Obstructive Lung Disease - Global Initiative for Chronic Obstructive Lung Disease - GOLD (2017), available at: https://goldcopd.org/ (Accessed: 21 June 2019).

15. Harrison, S.L. et al. (2015), "Self-management following an acute exacerbation of COPD: A systematic review", Chest, 147(3), pp. 646-61, https://doi.org/10.1378/chest.14-1658

16. Howard, C. \& Dupont, S. (2014), "'The COPD breathlessness manual": a randomised controlled trial to test a cognitive-behavioural manual versus information booklets on health service use, mood and health status, in patients with chronic obstructive pulmonary disease", NPJ Prim care Respir Med., (24), p. 14076, https://doi.org/10.1038/npjpcrm.2014.76.

17. Johnson-Warrington, V. et al. (2016), "Can a supported self-management program for COPD upon hospital discharge reduce

Тимрук-Скоропад, К., Павлова, Ю., Сидорик, Н. (2019), "Стратегія самоменеджменту у навчальних програмах для пацієнтів із хронічним обструктивним захворюванням легень", СлобожанСький науково-спортивн

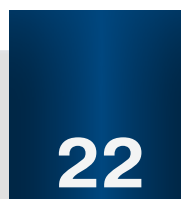

Tymruk-Skoropad, K., Pavlova, lu. \& Sydoryk, N. (2019), "Selfmanagement strategy in training programs for patients with chronic obstructive pulmonary disease", Slobozans 'kij naukovosportivnij visnik, No. 6(74), pp. 16-24, doi:10.15391/snsv.2019
6.003 


\section{СЛОБОЖАНСЬКИЙ НАУКОВО-СПОРТИВНИЙ ВІСНИК}

readmissions? A randomized controlled trial", International journal of chronic obstructive pulmonary disease, (11), pp. 1161-9, https://doi. org/10.2147/COPD.S91253.

18. Jolly, K. et al. (2018), "Self management of patients with mild COPD in primary care: Randomised controlled trial", BMJ (Online), BMJ Publishing Group, (361), https://doi.org/10.1136/bmj.k2241.

19. Jonsdottir, H. et al. (2015), "Effectiveness of a partnership-based self-management programme for patients with mild and moderate chronic obstructive pulmonary disease: a pragmatic randomized controlled trial", Journal of advanced nursing. England, 71(11), pp. 26342649, https://doi.org/10.1111/jan. 12728.

20. Kaptein, A., Fischer, M. \& Scharloo, M. (2014), "Self-management in patients with COPD: theoretical context, content, outcomes, and integration into clinical care", International Journal of Chronic Obstructive Pulmonary Disease, 9(1), p. 907, https://doi.org/10.2147/COPD. S49622.

21. Khan, A. et al. (2017), "Self-management behaviour and support among primary care COPD patients: cross-sectional analysis of data from the Birmingham Chronic Obstructive Pulmonary Disease Cohort", NPJ Primary Care Respiratory Medicine. Nature Publishing Group, 27(1), p. 46, https://doi.org/10.1038/s41533-017-0046-6.

22. Lopez-Lopez, L. et al. (2019), "Results on health-related quality of life and functionality of a patient-centered self-management program in hospitalized COPD: a randomized control trial", Disability and rehabilitation, England, pp. 1-9, https://doi.org/10.1080/09638288 2019.1609099.

23. Mandel, A.R. \& Keller, S.M. (1986), "Stress management in rehabilitation", Archives of physical medicine and rehabilitation, 67(6), pp. 375-9

24. Marquis, N. etal. (2014), "Are improvements maintained after in-home pulmonary telerehabilitation for patients with chronic obstructive pulmonary disease?", International journal of telerehabilitation. University Library Systems, University of Pittsburgh, 6(2), pp. 21-30. https:// doi.org/10.5195/ijt.2014.6156.

25. Mitchell, K.E. et al. (2014), "A self-management programme for COPD: a randomised controlled trial", The European respiratory journal, European Respiratory Society, 44(6), pp. 1538-47, https://doi.org/10.1183/09031936.00047814.

26. Murphy, L.A. et al. (2017), "Clinical-effectiveness of self-management interventions in chronic obstructive pulmonary disease: An overview of reviews", Chronic Respiratory Disease. SAGE Publications Sage UK: London, England, 14(3), pp. 276-288, https://doi. org/10.1177/1479972316687208.

27. Newham, J J etal. (2017), "Features of self-management interventions for people with COPD associated with improved health-related quality of life and reduced emergency department visits: a systematic review and meta-analysis", International journal of chronic obstructive pulmonary disease, New Zealand, (12), pp. 1705-1720, https://doi.org/10.2147/COPD.S133317.

28. Ng, W.I. and Smith, G.D. (2017), "Effects of a self-management education program on self-efficacy in patients with COPD: a mixedmethods sequential explanatory designed study", International journal of chronic obstructive pulmonary disease, (12), pp. 2129-2139, https:// doi.org/10.2147/COPD.S136216.

29. Nyberg, A., Tistad, M. and Wadell, K. (2019), "Can the COPD web be used to promote self-management in patients with COPD in swedish primary care: a controlled pragmatic pilot trial with 3 month- and 12 month follow-up", Scandinavian Journal of Primary Health Care, Taylor and Francis Ltd, 37(1), pp. 69-82, https://doi.org/10.1080/02813432.2019.1569415.

30. Rice, K. et al. (2014), "Collaborative Self-Management and Behavioral Change", Clinics in Chest Medicine. Elsevier, 35(2), pp. 337351, https://doi.org/10.1016/J.CCM.2014.02.004

31. Richard, A.A. and Shea, K. (2011), "Delineation of Self-Care and Associated Concepts", Journal of Nursing Scholarship, John Wiley \& Sons, Ltd (10.1111), 43(3), https://doi.org/10.1111/j.1547-5069.2011.01404.x.

32. Sanchez-Nieto, J.M. etal. (2016), "Efficacy of a self-management plan in exacerbations for patients with advanced COPD", International journal of chronic obstructive pulmonary disease, New Zealand, (11), pp. 1939-1947, https://doi.org/10.2147/COPD.S104728.

33. Sohanpal, R., Epiphaniou, E. and Taylor, S. (2014), "Self-management for COPD?: why does it generate negative connotations?", The British journal of general practice : the journal of the Royal College of General Practitioners. British Journal of General Practice, 64(625), pp. e522-4, https://doi.org/10.3399/bjgp14X681157.

34. Spruit, M.A. et al. (2013), "An Official American Thoracic Society/European Respiratory Society Statement: Key Concepts and Advances in Pulmonary Rehabilitation", American Journal of Respiratory and Critical Care Medicine, 43(5), pp. 1326-37, https://doi. org/10.1183/09031936.00145613

35. Tymruk-Skoropad, K. et al. (2019), "Educational component in rehabilitation programs for persons with chronic obstructive pulmonary disease: a systematic review". Advances in Rehabilitation, (4)

36. van Kruijssen, V. et al. (2015), "Use of Online Self-Management Diaries in Asthma and COPD: A Qualitative Study of Subjects' and Professionals' Perceptions and Behaviors", Respiratory care. Respiratory Care, 60(8), pp. 1146-56, https://doi.org/10.4187/ respcare.03795.

37. Voncken-Brewster, V. et al. (2015), "A randomized controlled trial evaluating the effectiveness of a web-based, computer-tailored selfmanagement intervention for people with or at risk for COPD", International journal of chronic obstructive pulmonary disease, New Zealand, (10), pp. 1061-1073, https://doi.org/10.2147/COPD.S81295.

38. Wang, T. et al. (2017), "Effectiveness of disease-specific self-management education on health outcomes in patients with chronic obstructive pulmonary disease: an updated systematic review and meta-analysis [with consumer summary]", Patient Education and Counseling, 100(8). pp. 1432-1446, https://doi.org/10.1016/J.PEC.2017.02.026.

Received: 01.11.2019.

Published: 30.12 .2019 .

\section{Відомості про авторів / Information about the Authors}

Тимрук-Скоропад Катерина Анатоліївна: кандидат наук з фізичного виховання і спорту, доцент кафедри фізичної терапії $і$ ерготерапії; Львівський державний університет фізичної культури імені Івана Боберського: вул. Костюшки, 11, м. Львів, Україна.

Тимрук-Скоропад Екатерина Анатольевна: кандидат наук по физическому воспитанию и спорту, доцент кафедры физической терапии и эрготерапии; Львовский государственный университет физической культуры имени Ивана Боберского: ул. Костюшко, 11, г.Львов, Украина.

Kateryna Tymruk-Skoropad: Doctor of Philosophy, Associate professor of physiotherapy and occupational therapy department, Lviv State University of Physical Culture: Kostushko Str., 11, Lviv, 79007, Ukraine.

ORCID.ORG/0000-0001-8152-0435

E-mail: tymruk_k@ukr.net

Павлова Юлія Олександрівна: доктор наук з фізичного виховання та спорту, старший науковий співробітник, професор кафедри теорії та методики фізичної культури; Львівський державний університет фізичної культури імені Івана Боберського: вул. Костюшка, 11, Львів, 79007, Україна.

Тимрук-Скоропад, К., Павлова, Ю., Сидорик, Н. (2019), "Стратегія самоменеджменту у навчальних програмах для пацієнтів із хронічним обструктивним захворюванням легень", Слобожанський науково-спортивний вісник, № 6(74), С. 16-24, doi: 10.15391/snsv.2019-6.003
Tymruk-Skoropad, K., Pavlova, lu. \& Sydoryk, N. (2019), "Selfmanagement strategy in training programs for patients with chronic obstructive pulmonary disease", Slobozans kij naukovo sportivnij visnik, No. 6(74), pp. 16-24, doi:10.15391/snsv.2019
6.003 


\section{SLOBOZANS'KIJ NAUKOVO-SPORTIVNIJ VISNIK}

Павлова Юлия Александровна: доктор наук по физическому воспитанию и спорту, старший научный сотрудник, профессор кафедры теории и методики физической культуры; Львовский государственный университет физической культуры имени Ивана Боберского: ул. Костюшко, 11, Львов, 79007, Украина.

Iuliia Pavlova: Doctor of Science (Physical Education and Sport), Senior Researcher, Professor of Theory and Methods of Physical Culture Department; Lviv State University of Physical Culture: Kostushko Str., 11, Lviv, 79007, Ukraine.

ORCID.ORG/0000-0002-8111-4469

E-mail: pavlova.j.o@gmail.com

Сидорик Надія Юліанівна: лікар-пульмонолог вищої категорії, Некомерційне комунальне підприємство "5 Міська клінічна лікарня", вул. Коновальця, м. Львів, Україна, 79013; медичний центр "Медікавер".

Сидорик Надежда Юлиановна: врач-пульмонолог высшей категории, Некоммерческое коммунальное предприятие "5 Городская клиническая больница", ул. Коновальца., г. Львов, Украина, 79013; медицинский центр "Медикавер".

Nadiya Sydoryk: Pulmonologist of the highest category, Non-profit municipal enterprise "5 City Clinical Hospital", str. Konovalets, Lviv, Ukraine, 79013; medical center "Medicare".

ORCID.ORG/0000-0002-2469-1243

E-mail: n.sydoryk.79@ukr.net 


\title{
Диференціація змісту навчальних занять з фізичного виховання $з$ урахуванням показників фізичного здоров'я та фізичної підготовленості школярів 7-9-х класів
}

Маргарита Мамешина
Харківська державна академія фізичної культури, Харків, Україна

\begin{abstract}
Мета: дослідити зміни показників фізичного здоров'я та фізичної підготовленості учнів 7-9-х класів під впливом програми диференціації змісту навчальних занять з фізичного виховання.

Матеріал і методи: аналіз та узагальнення науково-методичної літератури; вивчення документальних матеріалів $і$ систематизація інформації; педагогічне спостереження; медико-біологічні методи; педагогічне тестування; педагогічний експеримент; методи математичної статистики. У дослідженні приймали участь 226 учнів 7-9-х класів.

Результати: за результатами первинного дослідження виявлено "середній" рівень фізичного здоров'я у школярів 7-х класів, "нижче середнього" - учнів 8-9-х класів та "низький" рівень фізичної підготовленості досліджуваного контингенту.

Висновки: встановлені позитивні та достовірні зміни $(p<0,05-0,001)$ показників фізичного здоров'я та фізичної підготовленості учнів 7-9-х класів основних груп, свідчать про ефективність запропонованої програми диференціації змісту навчальних занять з фізичного виховання.
\end{abstract}

Ключові слова: диференціація, фізичне виховання, фізичне здоров'я, фізична підготовленість, школярі 13-15 років.

\section{Вступ}

Стан здоров'я населення, особливо молодого покоління, є одним із факторів, від якого залежать економічний та соціальний прогрес нашої держави. У той же час несприятливі соціальні умови життя, надмірне розумове та нервове навантаження; зниження інтересу до занять фізичною культурою та спортом, а іноді і негативне ставлення до них; малорухливий спосіб життя призводять до погіршення стану здоров'я підростаючого покоління [12; 24]. Так, досліджуючи рівень фізичного здоров'я дітей шкільного віку (6-18 років), рядом авторів [5; 23] встановлено, що "низький" рівень фізичного здоров'я мають 56\% учнів, "нижче середнього" - 36\% і тільки 7,5\% "високий". Не визиває сумніву і той факт, що від стану здоров'я залежить і рівень фізичної підготовленості дітей, який також суттєво знижується. Згідно даних наукових досліджень $36,4 \%$ дітей та підлітків мають "низький" рівень фізичної підготовленості, 33,5\% - "нижче середнього", 22,6\% "середній", 6,7\% - "вище середнього" і лише 0,8\% - "високий" $[4 ; 14 ; 25]$.

На думку провідних фахівців, головну роль у формуванні здорового покоління відіграє фізичне виховання. Однак ряд авторів зазначають, що система фізичного виховання в закладах освіти, в основному, функціонує малоефективно [16; 24]. Тому актуальним залишається питання пошуку нових, більш ефективних підходів до організації та змістового наповнення навчального процесу 3 фізичного виховання, впровадження нетипових форм занять з метою виховання здорової та всебічно розвинутої особистості.

Сучасні дослідники вказують, що вирішити зазначену проблему можна за рахунок оновлення змісту фізичного виховання нетрадиційними видами рухових дій, такими як чирлідинг [2]; snag-гольф [8]; оздоровчий туризм [28] тощо.
Аналіз наукових доробок стосовно питання диференційованого підходу у фізичному вихованні виявив значну кількість праць, де автори доводять, що визначення критеріїв та розподіл учнів на типологічні групи надає змогу адаптувати зміст фізичного виховання відповідно до індивідуальних можливостей кожної дитини та зробити його більш ефективним $[1 ; 10 ; 12]$.

Проте слід зазначити, що проблема диференціації змісту навчальних занять з фізичного виховання учнів середніх класів на основі результатів моніторингу фізичного здоров'я та рівня розвитку фізичних якостей $є$ недослідженою.

У зв'язку з вищезазначеним, своєчасним $є$ питання щодо розробки та впровадження в освітній процес основної школи програми диференціації змісту навчальних занять з фізичного виховання з урахуванням індивідуальних особливостей учнів та визначення ефективності впливузапропонованих нововведень на рівень фізичного здоров'я та фізичної підготовленості школярів 7-9-х класів.

Мета дослідження: дослідити зміни показників фізичного здоров'я та фізичної підготовленості учнів 7-9-х класів під впливом програми диференціації змісту навчальних занять з фізичного виховання.

Завдання дослідження:

1. Встановити рівень фізичного здоров'я та розвитку фізичних якостей учнів 13-15 років.

2. Визначити зміни показників фізичного здоров'я та фізичної підготовленості школярів 7-9-х класів у процесі застосування програми диференціації змісту навчальних занять з фізичного виховання.

Зв'язок дослідження 3 науковими програмами, планами, темами. Дослідження проводилось згідно Зведеного плану НДР у сфері фізичної культури та спорту на 2011-2015 рр. Міністерства освіти, науки, молоді та спорту України за напрямком 3. "Теоретико-методологічні та технологічні основи фізичного виховання і спорту для 


\section{SLOBOZANS'KIJ NAUKOVO-SPORTIVNIJ VISNIK}

всіх" з проблеми № 3.1 "Удосконалення програмнонормативних основ фізичного виховання в навчальних закладах" (№ державної реєстрації 0111U001733) та Тематичного плану науково-дослідної роботи Харківської державної академії фізичної культури на 2016-2020рр. за темою "Вдосконалення процесу фізичного виховання в навчальних закладах різного профілю" (№ державної реєстрації 0115U006754).

\section{Матеріал і методи дослідження}

3 метою визначення рівня фізичного здоров'я та фізичної підготовленості школярів 7-9-х класів було проведено констатувальний експеримент, у ході якого встановлено ідентичність основних і контрольних груп ( $>>0,05)$. У дослідженні приймали участь 226 учнів 7-9-х класів загальноосвітньої школи № 150 м. Харкова, з яких було сформовано 3 основні групи (66 хлопців, 79 дівчат) та 3 контрольні (41 та 40 відповідно).

Упродовж експерименту навчальний процес школярів 7-9-х класів контрольних груп здійснювався згідно з державною програмою, для закладів загальної середньої освіти "Фізична культура. 5-9 класи", зміст та його організація були стандартними.

На основі аналізу результатів первинного дослідження, була розроблена програма диференціації змісту навчальних занять з фізичного виховання з урахуванням показників фізичного здоров'я та фізичної підготовленості учнів основних груп. Програма побудована відповідно основних положень і включає: мету, завдання, основні методичні принципи навчання та структуру річного циклу реалізації програмного матеріалу варіативного компоненту державної програми. Принциповою відмінністю експериментальної програми є диференціація змісту уроків фізичної культури відповідно до типологічних особливостей учнів; вдосконалення педагогічних прийомів організації навчального процесу; розробка різнорівневих завдань для кожної типологічної групи. Так, зміст програмного матеріалу навчальних занять з фізичного виховання було поділено на два рівні: основний та варіативний. Основний рівень містив інваріантну складову, яка поділялася на теоретико-методичні знання та загальну фізичну підготовку та варіативну складову, до якої увійшли модулі: легка атлетика, волейбол, баскетбол, футбол.

На підставі диференціації навчального матеріалу з урахуванням функціональної та рухової підготовленості школярів основних груп, ми розробили зміст варіативного рівня і поділили його на два підрівні. 1-й підрівень містить вправи, спрямовані на підвищення функціональної підготовленості. До яких увійшли комплекси фізичних вправ та рухливі ігри, спрямовані на: покращення регуляції серцево-судинної системи та підвищення функціональних можливостей дихальної системи. 2-й підрівень - вправи, спрямовані на підвищення рівня фізичної підготовленості. До якого увійшли комплекси фізичних вправ та рухливі ігри, спрямовані на: підвищення рівня розвитку силових швидкісних здібностей та підвищення рівня розвитку координаційних здібностей і гнучкості.

Практична реалізація запропонованої програми також мала деякі новації. Так, у підготовчій частині вирішувалися завдання теоретичної та загальної фізичної підготовки. За рахунок раціональної організації учнів, підвищення інтенсивності та поточного виконання загальнорозвивальних вправ, її тривалість була скорочена до 10 хв. В основній частині уроку вирішувалися завдання технічної та технікотактичної підготовки запланованих навчальних варіативних модулів. На вирішення цих завдань відводилося 10-15 хв. Після вирішення основних завдань учні основних груп поділялися на 4 підгрупи (А - учні з "низьким" та "нижче середнього" рівнем регуляції серцево-судинної системи; Б - з "низьким" та "нижче середнього" рівнем функціональних можливостей системи дихання, В - 3 "низьким" і "нижче середнього" рівнем розвитку сили та швидкісних здібностей, Г - учні з "низьким" і "нижче середнього" рівнем розвитку координаційних здібностей та гнучкості), отримували індивідуальні картки завдання і виконували специфічні рухові дії, спеціально підібрані для кожної сформованої типологічної підгрупи. На виконання запропонованих вправ було відведено 10-15 хвилин. У заключній частині уроку вирішувалися завдання відновлення організму, підводилися підсумки та надавалося диференційоване домашнє завдання з урахуванням індивідуальних особливостей школярів. Тривалість становила 3-5 хв. Реалізація змісту варіативного рівня здійснювалася відповідно до періодизації фізичної підготовки учнів [6]. Навантаження змінювалося поступово, відповідно до віку, статі та індивідуальних можливостей учнів.

У ході дослідження використовувалися наступні методи. Теоретичні: аналіз та узагальнення науковометодичної літератури, вивчення документальних матеріалів і систематизація інформації. Емпіричні: педагогічне спостереження; медико-біологічні методи (для визначення рівня фізичного здоров'я школярів середніх класів використовувався метод експрес-оцінки, запропонований С. Д. Поляковим зі співавторами); педагогічне тестування; педагогічний експеримент. Методи математичної статистики.

\section{Результати дослідження}

Рівень фізичного здоров'я учнів 13-15 років визначався за показниками індексів Кетле 2, Робінсона, Скібінські, Шаповалової та Руф'є. Проведений аналіз даних виявив "середній" рівень фізичного здоров'я в учнів 13 років обох досліджуваних груп та хлопців 14 років контрольних групи. "Нижче середнього" рівень встановлено у школярів 15 років обох досліджуваних груп, учнів 14 років основних груп та дівчат 14 років контрольних груп.

Рівень фізичної підготовленості школярів визначалася за показниками розвитку основних фізичних якостей. Для цього застосовувалися рухові тести, запропоновані Л. П. Сергієнко [17; 18] та В. О. Романенко [19]. Так, результати первинного дослідження свідчать про "низький" рівень фізичної підготовленості учнів 7-9-х класів (швидкісні здібності - 2 бали, координаційні здібності, сила, гнучкість та витривалість - 1 бал відповідно).

Аналізуючи дані, отримані після педагогічного експерименту, визначено, що в показниках, які відображають рівень фізичного здоров'я, як у хлопців, такі дівчат основних груп, відбулися достовірні позитивні зміни за усіма досліджуваними параметрами ( $<<0,05-0,001)$. Так, показники довжини тіла хлопців основних груп варіювали від 1571,11 да 1748,95 см, у дівчат - від 1562,73 до 1661,30 см; маси тіла у хлопців становили від 46,78 до 59,58 кг, у дівчат - від 45,73 до 50,61; показники артеріального тиску (АТ) у хлопців становили від 102,34/68,06 до 109,37/71,05 мм рт. ст., у дівчат - від 101,55/66,42 до 106,30/70,13 мм рт. ст.; дані частоти серцевих скорочень (ЧСС) у хлопців варіювали від 


\section{СЛОБОЖАНСЬКИЙ НАУКОВО-СПОРТИВНИЙ ВІСНИК}

75,17 до 76,79 уд. ' хв ${ }^{-1}$, у дівчат - від 76, 15 до 76,48 уд. 'хв ${ }^{-1}$; результати життєвої ємкості легень (ЖЄЛ) у хлопців знаходилися в межах від 2472,22 до 3278,95 мл, у дівчат - від 2300,00 до 2760,87 мл; показники часу затримки дихання (проба Штанге) у хлопців варіювали від 41,21 до 44,32 с, у дівчат - від 39,97 до 44,04 с; результати виконання підйому тулуба в сід у хлопців варіювали в межах від 32,58 до 46,67 разів, у дівчат - від 29,57 до 42,70 разів; показники ЧСС у спокої $\left(\mathrm{P}_{1}\right)$ у хлопців становили від 16,33 до 19,47 ударів, у дівчат - від 16,55 до 17,26 ударів; ЧСС за перші 15 с першої хвилини відновлення $\left(\mathrm{P}_{2}\right)$ у хлопців становили від 29,94 до 33,76 ударів, у дівчат - від 30,00 до 32,43 ударів; дані ЧСС за останні 15 с першої хвилини відновлення $\left(\mathrm{P}_{3}\right)$ у хлопців становили від 18,28 до 21,74 ударів, у дівчат - від 18,79 до 19,61 ударів.

Унаслідок вищенаведеного рівень фізичного здоров'я підвищився у хлопців 7-х класів з "середнього" до "вище середнього", у школярів 8-9-х класів з "нижче середнього" до "середнього". Виняток становлять показники дівчат 7-х класів, де збільшення загальної суми балів за п'ятьма індексами з 14 до 17 балів на рівневій шкалі не відобрази-

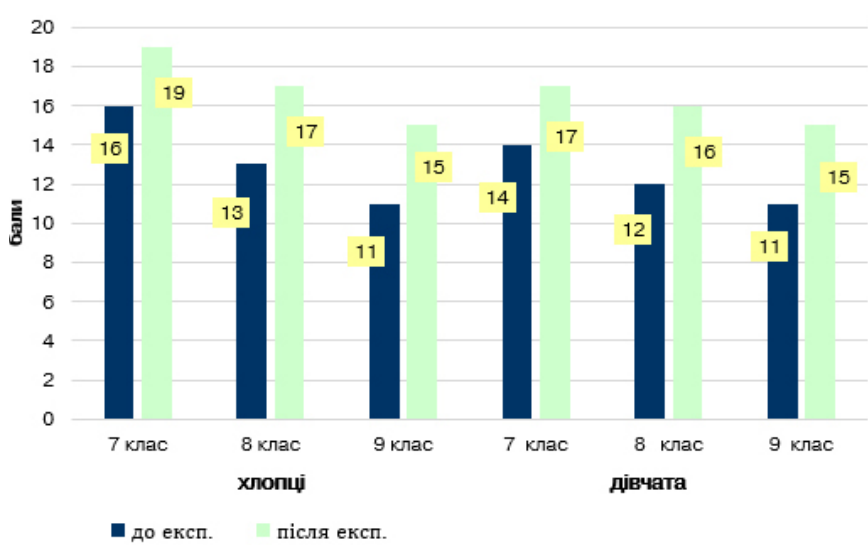

Рис. 1. Показники загального рівня фізичного здоров'я учнів основних груп до та після експерименту

лося (рис. 1).

Найбільш суттєво покращилися показники регуляції серцево-судинної системи учнів 13-15 років (з "нижче середнього" рівня до "середнього") та стану дихальної системи хлопців 15 років і дівчат 13-14 років (з "низького" до "середнього" рівня).

У школярів контрольних груп після експерименту суттєвих змін не визначено. Виняток становлять показники довжини та маси тіла, де зміни достовірні ( $<<0,05-0,001)$; питомої інтенсивності виконуваної роботи хлопців 9-х класів, де рівень підвищився з "низького" до "нижче середнього"; регуляції серцево-судинної системи дівчат 8-х класів, де рівень 3 "нижче середнього" підвищився до "середнього" і хлопців 9-х класів, де, навпаки, рівень знизився з "середнього" до "нижче середнього". Однак ці зміни на рівні фізичного здоров'я школярів контрольних груп суттєво не позначилися і він залишився на первинному "нижче середнього" рівні.

Аналіз результатів розвитку фізичних якостей, отриманих після впровадження розробленої програми, свідчить про позитивні зміни за усіма параметрами, що досліджувалися $(p<0,05-0,001)$ (табл. 1).

Так, приріст показників розвитку швидкісних здібностей у середньому варіював від 2\% до 17\% у хлопців та від
$1 \%$ до 15\% у дівчат; координаційних здібностей - від 3\% до 118\% та від 6\% до 103\% відповідно; силових здібностей - від 16,7\% до 42,11\% та від 16,52\% до 28,95\% відповідно; гнучкості - від 2\% до 26\% та від 4\% до 33\% відповідно; витривалості - від 16\% до 59\% у хлопців та від 22\% до $39 \%$ у дівчат.

Більш суттєво покращилися показники розвитку сили учнів $14-15$ років $(31,8 \%$ та $30,5 \%$ відповідно); гнучкості та швидкісних здібностей - школярів 15 років $(17,7 \%$ та 12,5\% відповідно); витривалості - учнів 13 років (49,5\%); координаційних здібностей - школярів 14 років (50,0\%).

Унаслідок цього, рівень розвитку фізичних якостей учнів основних груп в середньому підвищився на 1,4 бали і став відповідати оцінці 2,4 бали (рис. 2).
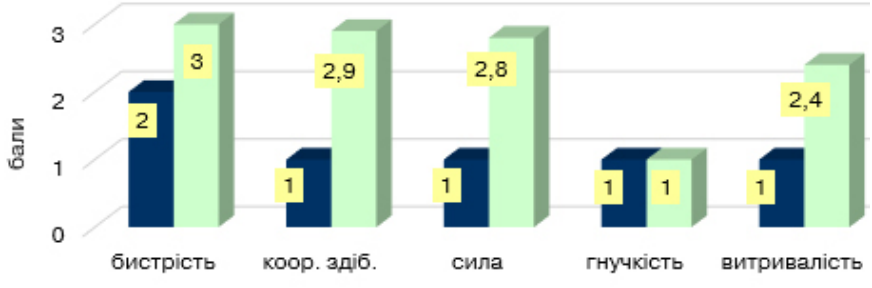

- до експ

після експ.

Рис. 2. Середні оцінки розвитку фізичних якостей учнів 7-9-х класів основних груп до та після експерименту

У результаті, рівень фізичної підготовленості учнів основних груп з "низького" підвищився до "нижче середнього".

Аналіз отриманих даних школярів контрольних груп не виявив суттєвих змін у показниках прояву фізичних якостей i, як наслідок, ї рівень фізичної підготовленості не змінився ("низький" рівень).

Із зазначено можна зробити висновок, що впровадження експериментальної програми диференціації змісту навчальних занять з фізичного виховання позитивно позначилося на рівні фізичного здоров'я та фізичної підготовленості учнів 7-9-х класів основних груп.

\section{Висновки / Дискусія}

Аналіз підсумків проведеного дослідження виявив, в основному, достовірне збільшення масо-ростових показників учнів усіх досліджуваних груп ( $<<0,05-0,001)$, що узгоджуються з даними ряду авторів [9; 22; 27], згідно яких підлітковий вік характеризується інтенсивним збільшенням розмірів тіла, в основному за рахунок подовження ніг, зростанню тулуба, збільшенням загальної маси м'язів, що, на наш погляд, підтверджує суто природний характер змін антропометричних показників школярів 13-15 років.

Проведений аналіз показників, які відображають функціональний стан серцево-судинної та дихальної систем, свідчить про те, що після впровадження вправ, спрямованих на підвищення функціональної підготовленості, виявлено тенденцію до зниження показників артеріального тиску і частоти серцевих скорочень та підвищення показників життєвої ємкості легень і часу затримки дихання у школярів 13-15 років основних груп $(p<0,01,0,001)$. Отримані дані підтверджуються рядом досліджень, у ході яких встановлено покращення функціональних можливостей кардіореспіраторної системи під впливом чирлідингу [2; 20]; аеробіки силової спрямо- 
Таблиця 1 Показники рівня розвитку фізичних якостей школярів основних груп до та після експерименту, $\overline{\mathbf{X}} \pm \mathbf{m}$

\begin{tabular}{|c|c|c|c|c|c|c|}
\hline \multirow{3}{*}{$\begin{array}{c}\text { Класи } \\
\mathbf{n} \\
\text { стать }\end{array}$} & \multicolumn{2}{|c|}{7 клас } & \multicolumn{2}{|c|}{8 клас } & \multicolumn{2}{|c|}{9 клас } \\
\hline & $(n=18)$ & $(n=33)$ & $(n=29)$ & $(n=23)$ & $(n=19)$ & $(n=23)$ \\
\hline & хлопці & дівчата & хлопці & дівчата & хлопці & дівчата \\
\hline \multicolumn{7}{|c|}{ Швидкісні здібності } \\
\hline \multicolumn{7}{|c|}{ "Естафетний" тест (см) } \\
\hline До експ. & $21,22 \pm 2,16$ & $20,39 \pm 1,34$ & $20,03 \pm 1,09$ & $21,48 \pm 1,99$ & $19,05 \pm 1,07$ & $15,54 \pm 1,38$ \\
\hline Після експ. & $16,44 \pm 0,66$ & $17,15 \pm 0,79$ & $16,00 \pm 0,65$ & $16,13 \pm 0,91$ & $15,47 \pm 0,45$ & $11,35 \pm 1,01$ \\
\hline$t$ & 2,68 & 4,10 & 7,31 & 4,08 & 5,00 & 4,35 \\
\hline$p$ & $<0,05$ & $<0,001$ & $<0,001$ & $<0,001$ & $<0,001$ & $<0,001$ \\
\hline \multicolumn{7}{|c|}{ Теппінг-тест за 10 с (кількість рухів) } \\
\hline До експ. & $35,83 \pm 1,58$ & $31,58 \pm 0,83$ & $36,69 \pm 1,50$ & $35,65 \pm 1,24$ & $31,26 \pm 1,27$ & $29,48 \pm 0,93$ \\
\hline Після експ. & $40,22 \pm 1,64$ & $36,36 \pm 0,88$ & $40,28 \pm 1,28$ & $38,96 \pm 1,13$ & $38,32 \pm 1,19$ & $33,65 \pm 0,96$ \\
\hline $\mathrm{t}$ & 9,16 & 7,70 & 9,21 & 9,52 & 8,65 & 19,88 \\
\hline$p$ & $<0,001$ & $<0,001$ & $<0,001$ & $<0,001$ & $<0,001$ & $<0,001$ \\
\hline \multicolumn{7}{|c|}{ Біг на 60 м (с) } \\
\hline До експ. & $10,24 \pm 0,16$ & $10,77 \pm 0,15$ & $10,34 \pm 0,15$ & $10,84 \pm 0,20$ & $9,75 \pm 0,11$ & $10,71 \pm 0,13$ \\
\hline Після експ. & $10,11 \pm 0,14$ & $10,66 \pm 0,14$ & $10,19 \pm 0,14$ & $10,73 \pm 0,20$ & $9,41 \pm 0,11$ & $10,43 \pm 0,11$ \\
\hline $\mathrm{t}$ & 5,66 & 6,19 & 10,09 & 8,65 & 10,45 & 7,74 \\
\hline$p$ & $<0,001$ & $<0,001$ & $<0,001$ & $<0,001$ & $<0,001$ & $<0,001$ \\
\hline \multicolumn{7}{|c|}{ Координаційні здібності } \\
\hline \multicolumn{7}{|c|}{ Ритмічне постукування руками (кількість циклів) } \\
\hline До експ. & $7,50 \pm 0,52$ & $7,18 \pm 0,37$ & $7,59 \pm 0,34$ & $8,13 \pm 0,66$ & $7,63 \pm 0,53$ & $7,74 \pm 0,46$ \\
\hline Після експ. & $10,28 \pm 0,44$ & $10,85 \pm 0,36$ & $10,79 \pm 0,32$ & $12,30 \pm 0,45$ & $10,53 \pm 0,51$ & $11,09 \pm 0,42$ \\
\hline $\mathrm{t}$ & 9,42 & 10,90 & 15,50 & 9,61 & 27,50 & 21,18 \\
\hline$p$ & $<0,001$ & $<0,001$ & $<0,001$ & $<0,001$ & $<0,001$ & $<0,001$ \\
\hline \multicolumn{7}{|c|}{ Десять "вісімок" (тест Копилова) (с) } \\
\hline До експ. & $14,69 \pm 0,97$ & $14,15 \pm 0,43$ & $15,55 \pm 0,49$ & $14,39 \pm 0,30$ & $13,58 \pm 0,61$ & $12,74 \pm 0,73$ \\
\hline Після експ. & $13,24 \pm 0,77$ & $13,34 \pm 0,54$ & $13,74 \pm 0,37$ & $13,19 \pm 0,23$ & $12,13 \pm 0,41$ & $11,37 \pm 0,41$ \\
\hline $\mathrm{t}$ & 3,63 & 2,15 & 11,37 & 9,59 & 5,85 & 3,07 \\
\hline$p$ & $<0,01$ & $<0,05$ & $<0,001$ & $<0,001$ & $<0,001$ & $<0,01$ \\
\hline \multicolumn{7}{|c|}{ Статична рівновага за методикою Бондаревського (c) } \\
\hline До експ. & $44,78 \pm 3,22$ & $43,33 \pm 1,71$ & $48,31 \pm 1,73$ & $48,09 \pm 1,80$ & $43,05 \pm 1,36$ & $48,87 \pm 3,00$ \\
\hline Після експ. & $57,33 \pm 1,68$ & $54,97 \pm 1,36$ & $56,17 \pm 1,19$ & $57,83 \pm 0,83$ & $51,16 \pm 0,77$ & $56,57 \pm 2,13$ \\
\hline $\mathrm{t}$ & 4,83 & 11,84 & 11,35 & 7,72 & 8,92 & 8,14 \\
\hline $\mathrm{p}$ & $<0,001$ & $<0,001$ & $<0,001$ & $<0,001$ & $<0,001$ & $<0,001$ \\
\hline \multicolumn{7}{|c|}{ Кидки малого м’яча в ціль (бали) } \\
\hline До експ. & $4,17 \pm 0,28$ & $4,15 \pm 0,29$ & $2,97 \pm 0,23$ & $2,74 \pm 0,38$ & $4,42 \pm 0,44$ & $4,96 \pm 0,28$ \\
\hline Після експ. & $7,00 \pm 0,36$ & $6,52 \pm 0,25$ & $5,83 \pm 0,16$ & $6,26 \pm 0,25$ & $6,05 \pm 0,42$ & $7,09 \pm 0,26$ \\
\hline $\mathrm{t}$ & 10,63 & 10,68 & 19,52 & 10,08 & 4,52 & 12,02 \\
\hline $\mathrm{p}$ & $<0,001$ & $<0,001$ & $<0,001$ & $<0,001$ & $<0,001$ & $<0,001$ \\
\hline \multicolumn{7}{|c|}{ Метання малого м’яча на дальність (м) } \\
\hline До експ. & $15,77 \pm 0,09$ & $8,51 \pm 0,06$ & $18,90 \pm 0,33$ & $8,78 \pm 0,08$ & $23,83 \pm 0,23$ & $9,41 \pm 0,06$ \\
\hline Після експ. & $16,33 \pm 0,08$ & $9,00 \pm 0,06$ & $19,39 \pm 0,24$ & $9,23 \pm 0,06$ & $24,66 \pm 0,17$ & $10,25 \pm 0,12$ \\
\hline $\mathrm{t}$ & 10,51 & 16,06 & 5,33 & 12,50 & 9,15 & 9,99 \\
\hline$p$ & $<0,001$ & $<0,001$ & $<0,001$ & $<0,001$ & $<0,001$ & $<0,001$ \\
\hline \multicolumn{7}{|c|}{ Силові здібності } \\
\hline \multicolumn{7}{|c|}{ Згинання та розгинання рук в упорі лежачи (кількість разів) } \\
\hline До експ. & $19,33 \pm 1,08$ & $12,39 \pm 0,50$ & $17,66 \pm 1,10$ & $10,70 \pm 0,72$ & $23,26 \pm 1,10$ & $8,70 \pm 0,35$ \\
\hline Після експ. & $24,06 \pm 0,54$ & $14,00 \pm 0,41$ & $24,52 \pm 0,46$ & $13,26 \pm 0,52$ & $26,42 \pm 0,99$ & $12,09 \pm 0,29$ \\
\hline $\mathrm{t}$ & 5,62 & 9,54 & 7,29 & 8,35 & 10,93 & 19,82 \\
\hline $\mathrm{p}$ & $<0,001$ & $<0,001$ & $<0,001$ & $<0,001$ & $<0,001$ & $<0,001$ \\
\hline & & грибки на о & нозі з прос & Іям вперед & & \\
\hline До експ. & $4,39 \pm 0,12$ & $3,78 \pm 0,07$ & $3,94 \pm 0,14$ & $3,68 \pm 0,15$ & $3,89 \pm 0,16$ & $3,71 \pm 0,08$ \\
\hline Після експ. & $4,89 \pm 0,13$ & $4,33 \pm 0,07$ & $4,74 \pm 0,10$ & $4,38 \pm 0,09$ & $5,08 \pm 0,13$ & $4,62 \pm 0,09$ \\
\hline $\mathrm{t}$ & 10,90 & 11,51 & 14,13 & 9,58 & 10,53 & 15,67 \\
\hline$p$ & $<0,001$ & $<0,001$ & $<0,001$ & $<0,001$ & $<0,001$ & $<0,001$ \\
\hline & & Піднімання & ба в сід (кіл & ь разів) & & \\
\hline До експ. & $44,56 \pm 0,63$ & $41,33 \pm 0,57$ & $36,86 \pm 1,76$ & $34,57 \pm 0,66$ & $28,16 \pm 1,22$ & $25,91 \pm 0,81$ \\
\hline Після експ. & $46,67 \pm 0,29$ & $42,70 \pm 0,49$ & $41,76 \pm 1,16$ & $38,70 \pm 1,15$ & $32,58 \pm 1,22$ & $39,04 \pm 1,10$ \\
\hline $\mathrm{t}$ & 4,35 & 9,11 & 4,87 & 3,28 & 15,84 & 11,78 \\
\hline
\end{tabular}




\section{СЛОБОЖАНСЬКИЙ НАУКОВО-СПОРТИВНИЙ ВІСНИК}

Продовж. табл. 1

\begin{tabular}{|c|c|c|c|c|c|c|}
\hline \multirow{3}{*}{$\begin{array}{c}\text { Класи } \\
\mathbf{n} \\
\text { стать }\end{array}$} & \multicolumn{2}{|c|}{7 клас } & \multicolumn{2}{|c|}{8 клас } & \multicolumn{2}{|c|}{9 клас } \\
\hline & $(n=18)$ & $(n=33)$ & $(n=29)$ & $(n=23)$ & $(n=19)$ & $(n=23)$ \\
\hline & хлопці & дівчата & хлопці & дівчата & хлопці & дівчата \\
\hline $\mathrm{p}$ & $<0,001$ & $<0,001$ & $<0,001$ & $<0,01$ & $<0,001$ & $<0,001$ \\
\hline \multicolumn{7}{|c|}{ Гнучкість } \\
\hline \multicolumn{7}{|c|}{ Нахил тулуба вперед з положення сидячи (см) } \\
\hline До експ. & $3,83 \pm 0,71$ & $8,21 \pm 0,93$ & $1,79 \pm 0,33$ & $10,87 \pm 1,56$ & $4,37 \pm 0,66$ & $11,04 \pm 1,72$ \\
\hline Після експ. & $4,33 \pm 0,74$ & $9,48 \pm 0,78$ & $2,62 \pm 0,30$ & $11,61 \pm 1,47$ & $5,79 \pm 0,64$ & $12,39 \pm 1,63$ \\
\hline $\mathrm{t}$ & 2,62 & 5,14 & 8,26 & 4,71 & 10,20 & 7,94 \\
\hline $\mathrm{p}$ & $<0,05$ & $<0,001$ & $<0,001$ & $<0,001$ & $<0,001$ & $<0,001$ \\
\hline \multicolumn{7}{|c|}{ Викрут прямих рук назад і вперед (см) } \\
\hline До експ. & $80,44 \pm 3,55$ & $83,67 \pm 2,38$ & $96,41 \pm 0,81$ & $75,78 \pm 4,19$ & $96,89 \pm 2,28$ & $83,26 \pm 3,86$ \\
\hline Після експ. & $79,33 \pm 3,64$ & $81,58 \pm 2,43$ & $94,93 \pm 0,79$ & $71,22 \pm 4,09$ & $93,58 \pm 2,20$ & $79,70 \pm 3,91$ \\
\hline $\mathrm{t}$ & 5,08 & 3,81 & 13,89 & 4,40 & 11,17 & 16,19 \\
\hline $\mathrm{p}$ & $<0,001$ & $<0,001$ & $<0,001$ & $<0,001$ & $<0,001$ & $<0,001$ \\
\hline \multicolumn{7}{|c|}{ Поперечний шпагат (см) } \\
\hline До експ. & $38,61 \pm 2,17$ & $28,97 \pm 2,00$ & $45,62 \pm 0,89$ & $28,00 \pm 2,31$ & $42,53 \pm 2,40$ & $28,91 \pm 2,53$ \\
\hline Після експ. & $35,83 \pm 2,25$ & $27,30 \pm 2,02$ & $44,28 \pm 0,88$ & $25,91 \pm 2,37$ & $40,37 \pm 2,36$ & $26,39 \pm 2,48$ \\
\hline $\mathrm{t}$ & 3,13 & 11,21 & 11,79 & 4,65 & 8,40 & 5,09 \\
\hline $\mathrm{p}$ & $<0,01$ & $<0,001$ & $<0,001$ & $<0,001$ & $<0,001$ & $<0,001$ \\
\hline \multicolumn{7}{|c|}{ Витривалість } \\
\hline \multicolumn{7}{|c|}{ Випригування з прогином (кількість разів) } \\
\hline До експ. & $11,67 \pm 0,47$ & $12,85 \pm 0,85$ & $20,14 \pm 1,14$ & $14,87 \pm 0,83$ & $19,79 \pm 0,64$ & $19,65 \pm 1,43$ \\
\hline Після експ. & $18,06 \pm 1,15$ & $17,30 \pm 0,98$ & $22,90 \pm 1,04$ & $17,83 \pm 0,74$ & $24,79 \pm 0,80$ & $23,48 \pm 1,25$ \\
\hline $\mathrm{t}$ & 5,42 & 6,24 & 10,20 & 12,80 & 15,41 & 12,28 \\
\hline $\mathrm{p}$ & $<0,001$ & $<0,001$ & $<0,001$ & $<0,001$ & $<0,001$ & $<0,001$ \\
\hline
\end{tabular}

ваності [15]; регбі-5 [21]; занять спортивним туризмом [28], системи фізичних вправ диференційованого навчання [10].

Аналіз результатів, що характеризують рівень фізичної підготовленості, отриманих після педагогічного експерименту, виявив достовірне підвищення показників, як у хлопців, так і дівчат основних груп, за усіма досліджуваними параметрами $(p<0,05-0,001)$. На наш погляд, позитивні зміни пояснюється тим, що зміст варіативного рівня запропонованої експериментальної програми було розроблено на основі диференціації навчального матеріалу з урахуванням індивідуальних можливостей учнів і доповнено комплексами фізичних вправ та модифікованими рухливими іграми, спрямованими на розвиток фізичних якостей.
Отримані результати узгоджуються з даними ряду авторів [3; 7] щодо ефективності впливу різних видів рухової діяльності на фізичну підготовленість дітей підліткового віку; ефективності диференціації навчального матеріалу з урахуванням рівня окремих рухових здібностей школярів $13-15$ років $[11 ; 13]$.

Таким чином, проведені дослідження свідчать про позитивний вплив запропонованої нами програми диференціації змісту навчальних занять з фізичного виховання на рівень фізичного здоров'я та фізичної підготовленості учнів7-9-х класів основної школи.

Перспективи подальших досліджень у цьому напрямку полягають у впроваджені в процес фізичного виховання іншого вікового контингенту програми диференціації змісту навчальних занять.

Конфлікт інтересів. Автор заявляє, що немає конфлікту інтересів, який може сприйматися таким, що може завдати шкоди неупередженості статті. Джерела фінансування. Ця стаття не отримала фінансової підтримки від державної, громадської або комерційної організацій.

\section{Список посилань}

1. Арефьєв, В.Г. (2017), "Педагогічні технології реалізації диференційованого фізичного виховання учнів основної школи", Науковий часопис Національного пед. університету імені М. П. Драгоманова, Вип. 3К(84), С. 29-32.

2. Бала, Т.М., Масляк, І.П. (2011), "Зміна рівня фізичного здоров'я школярів 7-9-х класів під впливом вправ чирлідингу", Спортивний вісник Придніпров’я, № 2, С. 21-23.

3. Бала, Т.М. (2012), "Динаміка рівня розвитку координаційних здібностей школярів 7-9-х класів під впливом черлідингу", Молода спортивна наука України, Вип. 16, Т. 2, С. 20-26.

4. Бала, Т.М., Сванадзе, А.С., Кузьменко, І.О. (2017), "Рівень фізичної підготовленості школярів 10-11-х класів", Науковий часопис Національного пед. університету імені М. П. Драгоманова, Вип. 6(88), С. 10-13

5. Боднар, І. (2014), Інтегративне фізичне виховання школярів різних медичних груп, ЛДУФК, Львів.

6. Круцевич, Т., Трачук, С., Нападій, А. (2016), "Планування навчального процесу з фізичної культури учнів середніх класів в загальноосвітніх навчальних закладах", Теорія і методика фізичного виховання і спорту, № 1, С. 36-42.

7. Кузьменко, І.О. (2015), "Рівень розвитку статичної та динамічної рівноваги школярів 5-9-х класів", Молода спортивна наука України, Вип. 19, Т. 2, С. 137-140.

8. Кузьменко, І.О. (2016), "Snag-гольф у фізичному вихованні школярів", Фізична культура, спорт та здоров'я: стан і перспек- 


\section{SLOBOZANS'KIJ NAUKOVO-SPORTIVNIJ VISNIK}

тиви в умовах сучасного українського державотворення в контексті 25-річчя Незалежності України: матеріали XVI Міжнародної науково-практичної конференції (Харків, 8-9 грудня 2016 р.), C. 41-44, режим доступy: http://hdafk.kharkov.ua/docs/konferences/ konf 8 12 2016.pdf.

9. Кузьменко, І. (2017), "Рівень фізичного розвитку учнів 7-8-х класів", Спортивна наука України, № 1(77), С. 34-37.

10. Мамешина, М.А., Масляк, І.П. (2017), "Рівень фізичного здоров'я учнів 7-8-х класів під впливом багаторівневої системи фізичних вправ диференційованого навчання", Вісник Кам'янець-Подільського національного університету імені Івана Огієнка, Вип. 10, С. 312-322.

11. Мамешина, М., Масляк, І. (2017), "Динаміка показників розвитку витривалості школярів 13-15 років під впливом багаторівневої системи диференційованого навчання", Матеріали XXIX Міжнародної науково-практичної інтернет-конференції "Тенденції та перспективи розвитку науки і освіти в умовах глобалізації", Вип. 29, С. 507-511.

12. Мамешина, М.А. (2018), "Вплив багаторівневої системи диференційованого навчання на рівень розвитку окремих рухових здібностей школярів 7-9-х класів", Матеріали XXXVII Міжнародної науково-практичної інтернет-конференції "Тенденції та перспективи розвитку науки і освіти в умовах глобалізації", Вип. 37, С. 255-262.

13. Мамешина, М.А. (2018), "Динаміка показників розвитку координаційних здібностей школярів 7-9-х класів під впливом багаторівневої системи диференційованого навчання", Науковий часопис НПУ імені М. П. Драгоманова, Вип. 10(104)18, С. 49-55.

14. Масляк, І.П., Вишня, В.О., Грида, Д.С. (2016), "Фізична підготовленість учнів середніх класів обласних загальноосвітніх шкіл", Матеріали II Всеукраїнська науково-практична конференція, С. 118-127.

15. Масляк, І.П. (2017), "Вплив аеробіки силової спрямованості на стан кардіореспіраторної системи школярів старших класів", Науковий часопис Національного пед. університету імені М. П. Драгоманова, Вип. 1(82), С. 35-38.

16. Москаленко, Н.В., Власюк, О.О., Степанова, І.В., Шиян, О.В. (2011), Інноваційні технології у фізичному вихованні школярів, Інновація, Дніпропетровськ.

17. Сергієнко, Л.П. (2001), Тестування рухових здібностей школярів, Олімпійська література, Київ.

18. Сергиенко, Л.П. (2015), "Определение развития силовых и анаэробных способностей в прыжковых тестах: классификация, методология измерений и нормативы оценки прыжков вверх с места", Слобожанський науково-спортивний вісник, № 5(49), С. 105-117.

19. Романенко, В.О. (2005), Диагностика двигательных способностей, ДонНУ, Донецк.

20. Bala, T.M. (2012), "The influence of cheerleading exercises on the schoolchildren's physical health of 5-9 ${ }^{\text {th }}$ forms", Pedagogics, psychology, medical-biological problems of physical training and sports, No. 4, pp. 12-16.

21. Filenko, L.V., Filenko, I.U. \& Martirosyan, A.A. (2013), "Research of indexes of physical development, physical preparedness and functional state of students aged 10-11 years under the influence of engagement in rugby-5", Pedagogics, psychology, medicalbiological problems of physical training and sports, No. 6, pp. 53-58, doi:10.6084/m9.figshare.714940.

22. Kuzmenko, I. (2017), "Investigation of the cardiovascular system of schoolchildren aged 13-14 years", Slobozhanskyi herald of science and sport, No. 6(62), pp. 51-53.

23. Mameshina, M. (2016), "Condition of physical health of pupils of the 7th-8th classes of the comprehensive school", Slobozhanskyi herald of science and sport, 5(55), pp. 47-52.

24. Masliak, I.P. (2015), "Quickness and endurance fitness of pedagogic college girl students under influence of cheer-leading", Physical Education of Students, No. 4, pp. 24-30, http://dx.doi.org/10.15561/20755279.2015.0404.

25. Maslyak, I.P., Shesterova, L.Ye., Kuzmenko, I.A., Bala, T.M., Mameshina, M.A., Krivoruchko, N.V. \& Zhuk, V.O. (2016), "The Influence of the vestibular analyzer functional condition on the physical fitness of school-age children", Sport science. International scientific journal of kinesiology, Vol. 9(2), pp. 20-27.

26. Maslyak, I.P. \& Krivoruchko, N.V. (2016), "Physical development of students of teacher training college as a result of exercises of cheerleading", Physical Education of Students, Vol. 1, pp. 55-63, http://dx.doi.org/10.15561/20755279.2016.0108.

27. Masliak, I.P. \& Mameshina, M.A. (2018), "Physical health of schoolchildren aged 14-15 years old under the influence of differentiated education", Pedagogics, psychology, medical-biological problems of physical training and sports, Vol. 22(2). pp. 92-98, http://dx.doi.org/10.1556 $1 / 18189172.2018 .0205$.

28. Mulyk, K.V. \& Grynova, T.I. (2015), "Influence of hiking trainings on 13 years old adolescents' health", Pedagogics, psychology, medicalbiological problems of physical training and sports, No. 8, pp. 40-44, http://dx.doi.org/10.15561/18189172.2015.0806.

29. Natalia Krivoruchko, Irina Masliak, Tetiana Bala, Shesterova Ludmula, Mameshina Margarita, Irina Kuzmenko \& Sergey Kotliar (2018), "Physical health assessment of 10-16 year old schoolgirls of the Kharkiv Region of Ukraine", Research Journal of Pharmaceutical, Biological and Chemical Sciences(RJPBCS), No. 9(4), pp. 1498-1506.

Стаття надійшла до редакції: 03.11.2019 р.

Опубліковано: 30.12.2019 р.

Аннотация. Маргарита Мамешина. Дифференциация содержания учебных занятий по физическому воспитанию с учетом показателей физического здоровья и двигательной подготовленности школьников 7-9-х классов. Цель: исследовать изменения показателей физического здоровья учащихся 7-9-х классов под воздействием программы дифференциации содержания учебных занятий по физическому воспитанию. Материал и методы: анализ и обобщение научно-методической литературы; изучение документальныхматериалов и систематизация информации; педагогическое наблюдение; медико-биологические методы; педагогическое тестирование; методы математической статистики. Результаты: по результатам первичного исследования определен "средний" уровень физического здоровья школьников 7-х классов, "ниже среднего" - учащихся 8-9-х классов и "низкий" уровень физической подготовленности исследуемого контингента. Выводы: выявленные и достоверные изменения (р<0,05-0,001) показателей физического здоровья и физической подготовленности учащихся 7-9-х классов основных групп свидетельствуют про эффективность предложенной программы дифференциации содержания учебных занятий по физическому воспитанию.

Ключевые слова: дифференциация, физическое воспитание, физическое здоровье, физическая подготовленность школьники 13-15 лет.

Abstract. Margarita Mameshina. Differentiation of the content of classes on physical education, taking into account indicators of physical health and physical preparedness of students in grades 7-9. Purpose: to study changes in the physical health indicators of students in grades 7-9 under the influence of a differentiation program for the content of physical education classes. Material \& Methods: analysis and generalization of scientific and methodological literature; study of documentary materials and systematization of information; pedagogical observation; biomedical methods; pedagogical testing; methods of mathematical statistics. Results: according to the results of the initial study, the "average" level of physical health of schoolchildren of 7th grades was determined, "below the average" - for students of 8-9th grades and the "low" level of physical preparedness of the studied contingent. Conclusions: the revealed and significant changes $(p<0,05-0,001)$ of indicators of physical health and physical preparedness of students in grades 7-9 of the main groups indicate the effectiveness of the proposed program for differentiating the content of physical education classes.

Keywords: differentiation, physical education, physical health, physical preparedness of schoolchildren 13-15 years old.

Мамешина, М. (2019), "Диференціація змісту навчальних занять 3 фізичного виховання з урахуванням показників фізичного здоров'я та фізичної підготовленості школярів 7-9-х класів", Слобожанський науково-спортивний вісник, № 6(74), С. 25-31, doi: 10.15391/snsv.2019-6.004
Mameshina, M. (2019), "Differentiation of the content of classes on physical education, taking into account indicators of physica health and physical preparedness of students in grades 7-9", Slobozans'kij naukovo-sportivnij visnik, No. 6(74), pp. 25-31, doi: 10.15391/snsv.2019-6.004 


\section{СЛОБОЖАНСЬКИЙ НАУКОВО-СПОРТИВНИЙ ВІСНИК}

\section{References}

1. Arefiev, V.H. (2017), "Pedagogical technologies for the implementation of differentiated physical education of primary school students", Naukovyi chasopys Natsionalnoho ped. universytetu imeni M. P. Drahomanova, Iss. 3K(84), pp. 29-32. (in Ukr.)

2. Bala, T.M. \& Masliak, I.P. (2011), "Changing the Physical Health Level of Grades 7-9 Students Under the Influence of Cheerleading Exercises", Sportyvnyi visnyk Prydniprov'ia, No. 2, pp. 21-23. (in Ukr.)

3. Bala, T.M. (2012), "Dynamics of level of development of coordination abilities of pupils of grades 7-9 under the influence of cheerleading", Moloda sportyvna nauka Ukrainy, Iss. 16, Vol. 2, pp. 20-26. (in Ukr.)

4. Bala, T.M., Svanadze, A.S. \& Kuzmenko, I.O. (2017), "Physical fitness level of 10-11th grade students", Naukovyi chasopys Natsionalnoho ped. universytetu imeni M. P. Drahomanova, Iss. 6(88), pp. 10-13. (in Ukr.)

5. Bodnar, I. (2014), Intehratyvne fizychne vykhovannia shkoliariv riznykh medychnykh hrup [Integrative Physical Education of Schoolchildren of Different Medical Groups], LSUPC, Lviv. (in Ukr.)

6. Krutsevych, T., Trachuk, S. \& Napadii, A. (2016), "Planning the educational process for physical education of middle-school students in secondary schools", Teoriia i metodyka fizychnoho vykhovannia i sportu, No. 1, pp. 36-42. (in Ukr.)

7. Kuzmenko, I.O. (2015), "The level of development of static and dynamic equilibrium of students in grades 5-9", Moloda sportyvna nauka Ukrainy, Iss. 19, Vol. 2, pp. 137-140. (in Ukr.)

8. Kuzmenko, I.O. (2016), "Snag Golf in Physical Education of Schoolchildren", Fizychna kultura, sport ta zdorov'ia: stan i perspektyvyvumovakh suchasnoho ukrainskoho derzhavotvorennia v konteksti 25-richchia Nezalezhnosti Ukrainy: materialy XVI Mizhnarodnoi naukovo-praktychnoi konferentsii (Kharkiv, 8-9 hrudnia 2016 r.), pp. 41-44, availaible at: http://hdafk.kharkov.ua/docs/konferences/konf 8 12 2016.pdf. (in Ukr.)

9. Kuzmenko, I. (2017), "The level of physical development of students in grades 7-8", Sportyvna nauka Ukrainy, No. 1(77), pp. 34-37. (in Ukr.)

10. Mameshyna, M.A. \& Masliak, I.P. (2017), "Physical health level of students in grades 7-8 under the influence of a multilevel system of differentiated physical exercises", Visnyk Kam'ianets-Podilskoho natsionalnoho universytetu imeni Ivana Ohiienka, Iss. 10, pp. 312-322. (in Ukr.)

11. Mameshyna, M. \& Masliak, I. (2017), "Dynamics of indicators of development of endurance of schoolboys of 13-15 years under the influence of multilevel system of differentiated learning", Materialy XXIX Mizhnarodnoi naukovo-praktychnoi internet-konferentsii "Tendentsii ta perspektyvy rozvytku nauky i osvity v umovakh hlobalizatsii", Iss. 29, pp. 507-511. (in Ukr.)

12. Mameshyna, M.A. (2018), "Influence of the multilevel system of differentiated learning on the level of development of individual motor abilities of pupils of grades 7-9", Materialy XXXVII Mizhnarodnoi naukovo-praktychnoi internet-konferentsii "Tendentsii ta perspektyvy rozvytku nauky i osvity v umovakh hlobalizatsii", Iss. 37, pp. 255-262. (in Ukr.)

13. Mameshyna, M.A. (2018), "Dynamics of indicators of development of coordination abilities of pupils of grades 7-9 under the influence of a multilevel system of differentiated learning", Naukovyi chasopys NPU imeni M. P. Drahomanova, Iss. 10(104)18, pp. 49-55. (in Ukr.)

14. Masliak, I.P., Vyshnia, V.O. \& Hryda, D.S. (2016), "Physical preparedness of middle school students of regional general education schools", Materialy II Vseukrainska naukovo-praktychna konferentsiia, pp. 118-127. (in Ukr.)

15. Masliak, I.P. (2017), "Effect of force aerobics on the condition of the cardiorespiratory system of high school students", Naukovyi chasopys Natsionalnoho ped. universytetu imeni M. P. Drahomanova, Iss. 1(82), pp. 35-38. (in Ukr.)

16. Moskalenko, N.V., Vlasiuk, O.O., Stepanova, I.V. \& Shyian, O.V. (2011), Innovatsiini tekhnolohii u fizychnomu vykhovanni shkoliariv [Innovative technologies in physical education of pupils], Dnipropetrovsk. (in Ukr.)

17. Serhiienko, L.P. (2001), Testuvannia rukhovykh zdibnostei shkoliariv [Testing of pupils' motor abilities], Olimpiiska literatura, Kyiv. (in Ukr.)

18. Sergienko, L.P. (2015), "Determination of the development of strength and anaerobic abilities in jump tests: classification, measurement methodology and standards for assessing upward jumps from the spot", Slobozans kij naukovo-sportivnij visnik, No. 5(49), pp. 105-117. (in Russ.)

19. Romanenko, V.O. (2005), Diagnostika dvigatelnykh sposobnostey [Diagnostics of motor abilities], DonNU, Donetsk. (in Russ.)

20. Bala, T.M. (2012), "The influence of cheerleading exercises on the schoolchildren's physical health of 5-9 $9^{\text {th }}$ forms", Pedagogics, psychology, medical-biological problems of physical training and sports, No. 4, pp. 12-16.

21. Filenko, L.V., Filenko, I.U. \& Martirosyan, A.A. (2013), "Research of indexes of physical development, physical preparedness and functional state of students aged 10-11 years under the influence of engagement in rugby-5", Pedagogics, psychology, medicalbiological problems of physical training and sports, No. 6, pp. 53-58, doi:10.6084/m9.figshare.714940.

22. Kuzmenko, I. (2017), "Investigation of the cardiovascular system of schoolchildren aged 13-14 years", Slobozhanskyi herald of science and sport, No. 6(62), pp. 51-53

23. Mameshina, M. (2016), "Condition of physical health of pupils of the 7th-8th classes of the comprehensive school", Slobozhanskyi herald of science and sport, 5(55), pp. 47-52.

24. Masliak, I.P. (2015), "Quickness and endurance fitness of pedagogic college girl students under influence of cheer-leading", Physical Education of Students, No. 4, pp. 24-30, http://dx.doi.org/10.15561/20755279.2015.0404.

25. Maslyak, I.P., Shesterova, L.Ye., Kuzmenko, I.A., Bala, T.M., Mameshina, M.A., Krivoruchko, N.V. \& Zhuk, V.O. (2016), "The Influence of the vestibular analyzer functional condition on the physical fitness of school-age children", Sport science. International scientific journal of kinesiology, Vol. 9(2), pp. 20-27.

26. Maslyak, I. \& \& Krivoruchko, N.V. (2016), "Physicaldevelopment of students ofteachertraining collegeasa resultofexercises ofcheerleading", Physical Education of Students, Vol. 1, pp. 55-63, http://dx.doi.org/10.15561/20755279.2016.0108

27. Masliak, I.P. \& Mameshina, M.A. (2018), "Physical health of schoolchildren aged 14-15 years old under the influence of differentiated education", Pedagogics, psychology, medical-biological problems of physical training and sports, Vol. 22(2). pp. 92-98, http://dx.doi.org/10.1556 $1 / 18189172.2018 .0205$

28. Mulyk, K.V. \& Grynova, T.I. (2015), "Influence of hiking trainings on 13 years old adolescents' health", Pedagogics, psychology, medicalbiological problems of physical training and sports, No. 8, pp. 40-44, http://dx.doi.org/10.15561/18189172.2015.0806.

29. Natalia Krivoruchko, Irina Masliak, Tetiana Bala, Shesterova Ludmula, Mameshina Margarita, Irina Kuzmenko \& Sergey Kotliar (2018), "Physical health assessment of 10-16 year old schoolgirls of the Kharkiv Region of Ukraine", Research Journal of Pharmaceutical, Biological and Chemical Sciences (RJPBCS), No. 9(4), pp. 1498-1506.

Received: 03.11.2019.

Published: 30.12 .2019 .

\section{Відомості про авторів / Information about the Authors}

Мамешина Маргарита Анатоліївна: Харківська державна академія фізичної культури: вул. Клочківська 99, Харків, 61058, Україна.

Мамешина Маргарита Анатольевна: Харьковская государственная академия физической культуры:ул. Клочковская 99, г. Харьков, 61058, Украина.

Margarita Mameshina: Kharkiv State Academy of Physical Culture: Klochkivska str. 99, Kharkiv, 61058, Ukraine.

ORCID.ORG/0000-0001-7397-3805

E-mail: mameshina.rita@gmail.com 


\title{
Використання спеціальних вправ для розвитку рухових якостей та формування техніко-тактичних дій захисників 13-14 років у підготовчому періоді
}

\author{
Ярослав Крайник \\ Вячеслав Мулик \\ Дар'я Окунь \\ Святослав Коваль
}

\author{
Харківська державна академія фізичної культури \\ Харків, Україна
}

Мета: розробити комплекси тренувальних програм для крайніх і центральних захисників з використанням спеціальних вправ відповідно до ігрового амплуа та визначити ефективність їх використання у юних футболістів 13-14 років. Матеріал і методи: у дослідженні приймали участь юні футболісти 13-14 років ФК "Арсенал" м. Харків у кількості 10 спортсменів протягом річного макроциклу (2018-2019). У процесі дослідження використовувалися педагогічне спостереження та визначення кількісних і якісних техніко-тактичних дій протягом матчу, методи математичної статистики. Результати: визначено вплив комплексів спеціальних бігових і стрибкових вправ, які додатково використовувалися у крайніх і центральних захисників відповідно до ігрового амплуа, на кількісні і якісні показники ігрової діяльності юних футболістів 13-14 років.

Висновки: отримані результати експериментально підтвердили ефективність застосування спеціалізованих бігових і стрибкових вправ окремо у крайніх і центральних захисників, що підвищує рівень виконання ними техніко-тактичних дій.

Ключові слова: крайні і центральні захисники, рухові якості, ігрове амплуа, техніко-тактичні дії, морфо-функціональні показники.

\section{Вступ}

Удосконалення системи підготовки юних спортсменів неможливо без пошуку нових підходів до організації навчально-тренувального процесу, а також використання новітніх досягнень спортивної науки у практичній роботі тренера $[8 ; 11 ; 13]$.

В існуючих дослідженнях $[1 ; 3 ; 4 ; 8 ; 12]$ відзначено необхідність покращення якості підготовки юних футболістів, пошуку і впровадження в практику найбільш ефективних засобів і методів тренувань, у зв'язку з чим необхідно проведення спеціального вивчення і аналізу різних аспектів даної проблеми. Одним із напрямків досліджень $€$ розробка засобів спеціальної фізичної підготовки юних футболістів 13-14 років різного ігрового амплуа [5; 7; 14]. Доцільність вирішення даного питання визначає те, що при проведенні тренувальних занять використання спеціальних засобів фізичної підготовки потребує врахування специфічних вимог до кожного футболіста залежно від ігрового амплуа [2; 6; 15].

У роботах $[10 ; 16 ; 17]$ розглядаються питання щодо особливостей підготовки польових гравців різного ігрового амплуа (захисник, півзахисник, нападник), але очевидно, що дії крайніх і центральних захисників і півзахисників мають суттєву різницю. Тому визначення особливостей використання спеціальних рухових вправ для крайніх та центральних захисників $€$ актуальним для проведення досліджень.

Зв'язок дослідження 3 науковими програмами, планами, темами. Робота проводиться відповідно до Ініціативної теми науково-дослідної роботи у галузі фізичної культури та спорту Харківської державної академії фізичної культури на 2019-2023 роки за темою "Удосконалення навчально-тренувального процесу в спортивних іграх", номер держреєстрації $0116 U 101644$
Мета дослідження: розробити зміст тренувальних програм для крайніх і центральних захисників з використанням спеціальних вправ відповідно до ігрового амплуа та визначити ефективність їх використання у юних футболістів 13-14 років.

Задачі дослідження:

1. Розробити комплекси рухових вправ та методику їх використання для крайніх і центральних футболістів 13-14 років з урахуванням ігрового амплуа.

2. Визначити вплив спеціальних бігових та стрибкових вправ, що використовують протягом підготовчого періоду, на кількісні і якісні показники техніко-тактичних дій крайніх і центральних захисників 13-14 років.

\section{Матеріал і методи дослідження}

У дослідженні приймали участь юні футболісти 13-14 років ФК "Арсенал" м. Харків у кількості 10 спортсменів протягом річного макроциклу (2018-2019). У процесі дослідження використовувалися педагогічне спостереження та визначення кількісних і якісних техніко-тактичних дій протягом матчу, методи математичної статистики.

Рухові дії, що здійснюють крайні захисники, суттєво відрізняються від дій центральних захисників і пов'язані з великим обсягом роботи, що потребує прояву витривалості, i, перш за все, анаеробної.

Підготовчий період експериментальної програми включав втягуючий, базовий із загальної та базовий з спеціальної фізичної підготовки.

Втягуючий мезоцикл є однаковим для всіх гравців команди і передбачає закладення бази загальної фізичної підготовки, у зв'язку з чим використовуються бігові вправи у різних модифікаціях: рівномірний і перемінний біг, фартлек. Крім цього, використовуються загальнофізичні вправи, які складають колове тренування, як на стадіоні, 


\section{СЛОБОЖАНСЬКИЙ НАУКОВО-СПОРТИВНИЙ ВІСНИК}

так і в тренажерному залі. Особлива увага також приділялася використанню легкоатлетичних вправ, які є основою рухів під час ривків і прискорень, а також різних переміщень (спиною вперед, схресним кроком, біг з захлестом голені та підніманням стегна та інше). Значна увага приділялася стрибковим вправам (багатоскоки, вистрибування вгору на одній та двох ногах та інше).

Проведений втягуючий мезоцикл дозволив сформувати базовий рівень фізичної і техніко-тактичної підготовленості юних футболістів 13-14 років. Наприкінці було визначено кількісні та якісні показники техніко-тактичних дій, під час гри крайніх і центральних захисників.

Подальший базовий мезоцикл із загальної фізичної підготовки передбачив використання у крайніх захисників додатково вправ з застосуванням бігу (рівномірної і перемінної інтенсивності), стрибків (через бар'єри, легкоатлетичні), силове тренування на тренажерах, а також з набивними м'ячами (оскільки крайньому захиснику приходиться здійснювати вкидання м'яча з-за бокової лінії). Особлива увага приділялася техніці рухових дій під час їх виконання.

У базовому мезоциклі зі спеціальної фізичної і технічної підготовки ускладнювалися вправи, які відповідали ігровим діям.

Так, для крайніх захисників використовувалися різні види бігових вправ у сполученні з подоланням перешкод, виконанням підкатів, єдиноборств, стрибків, відбору м'яча та подальших технічних дій, пов'язаних з передачею м'яча. Крім того, при виконанні вправ особлива увага приділялася техніці їх виконання.

Слід зазначити, що виконання ривків здійснювалося за рахунок частоти рухів, а прискорення переважно за рахунок довжини кроків.

\section{Результати дослідження}

Застосування спеціальних бігових та стрибкових вправ дозволило суттєво збільшити кількість і якість виконання техніко-тактичних дій крайніх захисників досліджуємої групи (табл. 1, 2). Збільшилася кількість ігрових рухових дій на $5,1 \%(t=2,49 ; p<0,05)$ за рахунок кількості виконаних ривків $(t=2,31 ; p<0,05)$ та прискорень $(t=4,06$; $\mathrm{p}<0,01)$, у той час як інші рухові дії, менш значущі для крайніх захисників, зменшилися на $8,0 \%(t=3,74 ; p<0,01)$ (табл. 3).

Поряд з цим достовірно підвищилася якість виконання техніко-тактичних дій крайніх захисників досліджуємої групи (табл. 2). Збільшилася кількість виконання середніх $(t=3,29 ; p<0,01)$ і довгих $(t=3,39 ; p<0,01)$ передач, підкатів $(t=2,59 ; p<0,05)$ та зупинень м'яча $(t=2,32 ; p<0,05)$, що виконуються на фоні втоми.

Побудова тренувального процесу центральних захисників у втягуючому мезоциклі має загальний зміст для всіх гравців команди та передбачає поступове підвищення навантажень для подальшої індивідуалізації занять у залежності від ігрових амплуа.

Базовий мезоцикл з ЗФП центральних захисників передбачав на базі аеробної витривалості використовувати біг з перемінною інтенсивністю (біг на 2000-2500 м; фартлек; човниковий біг), стрибкові легкоатлетичні вправи; вправи силового характеру; колове тренування, вправи зі штангою.

у базовому мезоциклі зі спеціальної фізичної підготовки центральні захисники додатково використовували вправи з урахуванням специфіки рухової діяльності, а саме: бігові вправи - фартлек, скиппінг, прискорення, ривки, різновиди бігу (правим і лівим боком, спиною впе-

Таблиця 1

Кількісні показники виконання техніко-тактичних дій крайніх захисників за час дослідження, \% (n=20)

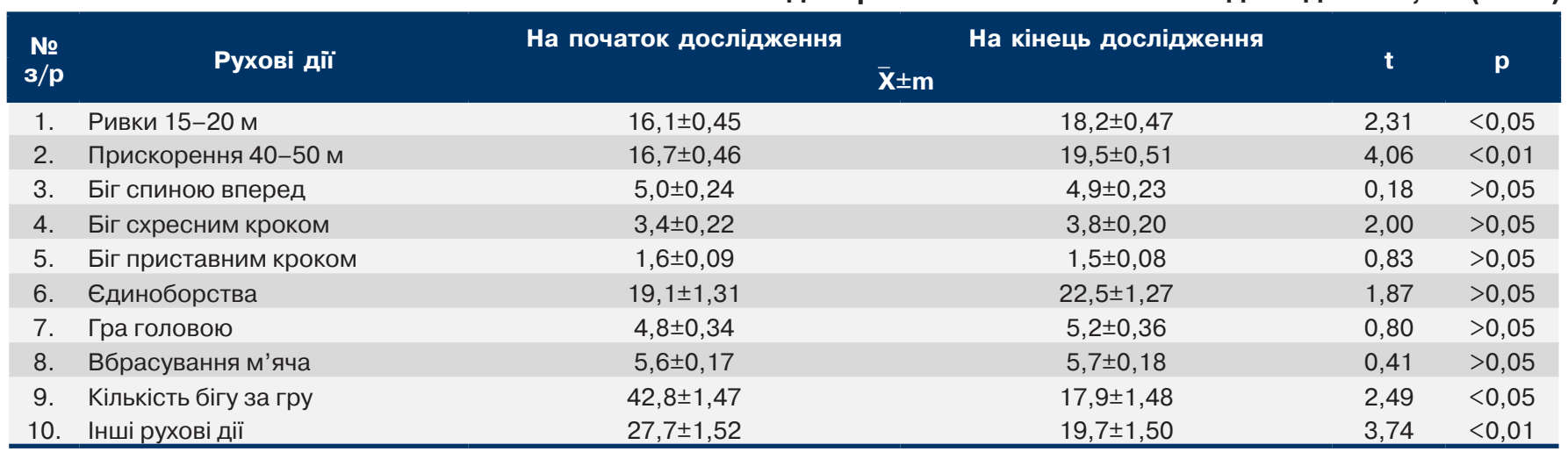

Таблиця 2

Показники якості виконання техніко-тактичних дій крайніх захисників за час дослідження, \% (n=20)

\begin{tabular}{|c|c|c|c|c|c|}
\hline $\begin{array}{l}\text { № } \\
3 / \mathrm{p}\end{array}$ & Техніко-тактичні дії & На початок дослідження & 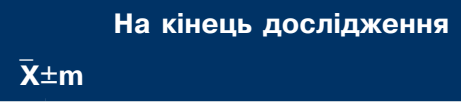 & $\mathbf{t}$ & $\mathbf{p}$ \\
\hline 1. & Короткі передачі & $31,2 \pm 1,24$ & $32,6 \pm 1,25$ & 0,80 & $>0,05$ \\
\hline 2. & Середні передачі & $28,1 \pm 1,24$ & $33,8 \pm 1,21$ & 3,29 & $<0,01$ \\
\hline 3. & Довгі передачі & $9,6 \pm 0,42$ & $11,7 \pm 0,46$ & 3,39 & $<0,01$ \\
\hline 4. & Обведення & $14,0 \pm 0,58$ & $15,8 \pm 0,58$ & 2,20 & $<0,05$ \\
\hline 5. & Ведення м'ячи & $26,2 \pm 1,03$ & $27,1 \pm 1,05$ & 0,61 & $>0,05$ \\
\hline 6. & Підкати & $30,0 \pm 1,58$ & $35,7 \pm 1,54$ & 2,59 & $<0,05$ \\
\hline 7. & Зупинки м'яча & $24,2 \pm 1,08$ & $27,8 \pm 1,4$ & 2,32 & $<0,05$ \\
\hline 8. & Удари ногою у ворота & $25,0 \pm 1,08$ & $26,1 \pm 1,09$ & 0,71 & $>0,05$ \\
\hline 9. & Удари головою & $20,3 \pm 1,05$ & $21,1 \pm 1,07$ & 0,53 & $>0,05$ \\
\hline
\end{tabular}




\section{SLOBOZANS'KIJ NAUKOVO-SPORTIVNIJ VISNIK}

ред, змійкою), звертаючи увагу на частоту і техніку рухів їх виконання; стрибкові вправи та їх комбінації з біговими вправами та ударами по м'ячу ногами і головою.

Використання спеціалізованих вправ дозволило у змагальному періоді (за 10 ігр) здійснювати більшу кількість ігрових дій, переважно тих, що притаманні центральним захисникам (табл. 3).

Так, суттєво збільшилися кількісні показники виконання ривків $(t=5,54 ; p<0,001)$, прискорень $(t=5,44$ $\mathrm{p}<0,001)$, бігу спиною вперед ( $\mathrm{t}=3,43 ; \mathrm{p}<0,01)$ та схресним кроком $(\mathrm{t}=2,19 ; \mathrm{p}<0,05)$, а також участі у єдиноборствах $(\mathrm{t}=2,30 ; \mathrm{p}<0,05)$ та гри головою $(\mathrm{t}=4,55 ; \mathrm{p}<0,001)$

За час дослідження достовірно збільшилася кількість різновидів бігу за гру ( $t=4,65 ; p<0,001)$, що зменшило виконання інших рухових дій (ходьба, біг у повільному русі та інше) ( $t=4,40 ; p<0,001)$, тобто підвищилася інтенсивність ігрової діяльності центральних захисників.

Під час виконання бігових і стрибкових вправ особлива увага приділялася техніці їх виконання, що позитивно вплинуло на якість виконання техніко-тактичних дій центральних захисників (табл. 4)

У процесі впровадження експериментальної методики із застосуванням спеціальних вправ підвищилися показники якості техніко-тактичних дій центральних захисників у виконанні: середніх $(t=4,92 ; p<0,01)$ і довгих $(t=5,54 ; p<0,001)$ передач, зупинок м'яча $(t=2,72$; $\mathrm{p}<0,05)$, ударів м'яча ногою $(\mathrm{t}=2,13 ; \mathrm{p}<0,05)$ та головою у ворота $(\mathrm{t}=2,42 ; \mathrm{p}<0,05)$.

\section{Висновки / Дискусія}

У проведених раніше дослідженнях [6; 9] встановле- но, що крайні і центральні захисники в ігровій діяльності мають значну різницю в показниках кількості і якості виконуємих техніко-тактичних дій.

Так, для крайніх захисників в більшій мірі притаманна участь у єдиноборствах та виконанні рухових дій аеробної витривалості.

Центральним захисникам, поряд з участю у єдиноборствах, суттєвіше є виконання ривків, що обумовлюють анаеробну витривалість. У зв'язку з чим виникає необхідність диференціювання спеціальної рухової діяльності крайніх і центральних захисників.

Отримані у даному дослідженні результати експериментально підтвердили припущення про ефективність застосування спеціалізованих бігових і стрибкових вправ окремо у крайніх і центральних захисників. Доведено, що у крайніх захисників у заняттях додатково доцільно використовувати різні види бігових вправ у сполученні з подоланням перешкод, виконанням підкатів, єдиноборств, стрибків, відбору м'яча та подальших технічних дій, пов'язаних з передачею м'яча. Крім того, при виконанні вправ особлива увага приділяється техніці іх виконання.

Для центральних захисників позитивним $€$ використання вправ з урахуванням специфіки рухової діяльності, а саме: бігові вправи - фартлек, скиппінг, прискорення, ривки, різновидності бігу (правим і лівим боком, спиною вперед, змійкою, звертаючи увагу на частоту і техніку рухів їх виконання; стрибкові вправи та їх комбінації з біговими вправами та ударами по м'ячу ногами і головою.

Отже, визначено, що в тренувальному процесі захисників доцільно використовувати спеціальні вправи відповідно до ігрового амплуа (крайні і центральні захисники).

Таблиця 3

Кількісні показники виконання техніко-тактичних дій центральних захисників за час дослідження, \% (n=20)

\begin{tabular}{|c|c|c|c|c|c|}
\hline $\begin{array}{l}\text { No } \\
\text { 3/p }\end{array}$ & Рухові дії & На початок дослідження & На кінець дослідження & $\mathbf{t}$ & $\mathbf{p}$ \\
\hline 1. & Ривки 15-20 м & $14,0-0,49$ & $18,1 \pm 0,56$ & 5,54 & $<0,001$ \\
\hline 2. & Прискорення 40-50 м & $12,5 \pm 0,47$ & $13,2 \pm 0,49$ & 5,44 & $<0,001$ \\
\hline 3. & Біг спиною вперед & $5,6 \pm 0,25$ & $6,8 \pm 0,24$ & 3,43 & $<0,01$ \\
\hline 4. & Біг схресним кроком & $3,2 \pm 0,22$ & $3,9 \pm 0,23$ & 2,19 & $<0,05$ \\
\hline 5. & Біг приставним кроком & $1,8 \pm 0,10$ & $1,9 \pm 0,12$ & 0,64 & $>0,05$ \\
\hline 6. & Єдиноборства & $21,5 \pm 1,40$ & $26,1 \pm 1,44$ & 2,30 & $<0,05$ \\
\hline 7. & Гра головою & $7,8 \pm 0,38$ & $10,3 \pm 0,40$ & 4,55 & $<0,001$ \\
\hline 8. & Кількість бігу за гру & $37,1 \pm 1,46$ & $46,9 \pm 1,52$ & 4,65 & $<0,001$ \\
\hline 9. & Інші рухові дії & $62,9 \pm 1,57$ & $53,1 \pm 1,54$ & 4,46 & $<0,001$ \\
\hline
\end{tabular}

Таблиця 4

Показники якості виконання техніко-тактичних дій центральних захисників за час дослідження, \% (n=20)

\begin{tabular}{|c|c|c|c|c|c|}
\hline $\begin{array}{l}\text { No } \\
3 / p\end{array}$ & Техніко-тактичні дії & На початок дослідження & На кінець дослідження & $\mathbf{t}$ & $\mathbf{p}$ \\
\hline 1. & Короткі передачі & $30,8 \pm 1,22$ & $31,9 \pm 1,24$ & 0,63 & $>0,05$ \\
\hline 2. & Середні передачі & $25,2 \pm 1,28$ & $34,6 \pm 1,42$ & 4,92 & $<0,001$ \\
\hline 3. & Довгі передачі & $10,1 \pm 0,44$ & $16,3 \pm 1,03$ & 5,54 & $<0,001$ \\
\hline 4. & Обведення & $15,1 \pm 0,59$ & $17,2 \pm 1,02$ & 1,78 & $>0,05$ \\
\hline 5. & Ведення м'ячи & $25,8 \pm 1,17$ & $27,1 \pm 1,19$ & 0,78 & $>0,05$ \\
\hline 6. & Підкати & $16,0 \pm 1,26$ & $17,1 \pm 1,28$ & 0,65 & $>0,05$ \\
\hline 7. & Зупинки м'яча & $26,2 \pm 1,18$ & $30,8 \pm 1,21$ & 2,72 & $<0,05$ \\
\hline 8. & Удари ногою у ворота & $25,0 \pm 1,08$ & $28,3 \pm 1,4$ & 2,13 & $<0,05$ \\
\hline 9. & Удари головою & $20,8 \pm 1,07$ & $24,5 \pm 1,09$ & 2,42 & $<0,05$ \\
\hline
\end{tabular}




\section{СЛОБОЖАНСЬКИЙ НАУКОВО-СПОРТИВНИЙ ВІСНИК}

Перспектива подальших досліджень полягає увизначені впливу використання спеціальних рухових вправ на формування факторної структури підготовленості юних футболістів 13-14 років різного ігрового амплуа.

Конфлікт інтересів. Автори заявляють, що немає конфлікту інтересів, який може сприйматися таким, що може завдати шкоди неупередженості статті. Джерела фінансування. Ця стаття не отримала фінансової підтримки від державної, громадської або комерційної організацій.

\section{Список посилань}

1. Бердникова, А.Н. (2018), "Особенности технико-тактическо и физической подготовки футболистов 13-14 лет", Человек. Спорт. Медицина, Т. 18, № 4, С. 73-79.

2. Даев, В.Е. (2007), Оптимизация спортивного отбора и ориентации футболистов по игровым амплуа на этапе углубленной специализайии: авторефрат, Малаховка.

3. Єрмоленко, П., Залойло, В. (2012), "Підготовка футболістів віком 11-15 років з урахуванням ігрового амплуа", Теорія і методика фізичного виховання і спорту, № 1, С. 16-22.

4. Журид, С.Н. (2007), "Модельные характеристики технико-тактических действий юніх футболистов 15 и 17 лет различных игровых амплуа", Слобожанський науково-спортивний вісник, № 12, С. 93-97.

5. Зайченко, А.С., Попов, Ю.А. (2017), "Совершенствование скоростных качеств физической подготовки футболистов разного игрового амплуа", Физическая культура: воспитание, образование тренировка, № 5, С. 34-36.

6. Коваль, С.С., Лебедєв, С.І. (2014), "Порівняльний аналіз командних кількісних показників техніко-тактичних дій футболістів 1012 років під час змагальної діяльності", Слобожанський науково-спортивний вісник, № 1(39), С. 48-52.

7. Коваль, С.С. (2010), "Исследование взаимосвязи скоростных качеств и технико-тактических действий юных футболистов 8-12 лет", Слобожанський науково-спортивний вісник, № 1, С. 99-102.

8. Костюкевич, В.М. (2006), Управление тренировочным процессом футболистов в годичном цикле подготовки: монография, Винница.

9. Мулик, В.В., Крайник, Я.Б. (2019), "Кількісні характеристики рухових дій юних футболістів під час змагальної діяльності на етапі попередньо-базової підготовки", Спортивні ігри, № 4(14), С. 48-57, doi: 10.15391/si.2019-4.05.

10. Ларин, О.С., Иванов, Н.В. (2016), "Особенности специальной физической подготовки юных футболистов с учетом игрового амплуа", Ученые записки университета имени П.Ф. Лесгафта, № 1(131), С. 123-125.

11. Лисенчук, Г.А. (2003), Управление подготовкой футболистов, Киев.

12. Лісенчук, Г., Попов, О., Хоменко, О. (2013), "Структура фізичної підготовленості футболістів", Теорія і методика фізичного виховання і спорту, № 3, С. 21-23.

13. Перевозник, В.І., Перцухов, А.А. (2015), "Рухова активність футболістів різного амплуа в умовах змагальної діяльності", Спортивные игры, № 11, С. 143-146.

14. Перцухов, А.А. (2009), "Оцінка надійності виконання техніко-тактичних дій футболістами 17-19 років різних ігрових амплуа", Слобожанський науково-спортивний вісник, № 3, С. 123-126.

15. Перцухов, А.А. (2013), "Сравнительная характеристика показателей специальной подготовленности центральных и крайних защитников 17-19 лет", Слобожанський науково-спортивний вісник, № 2, С. 62-67.

16. Собко, С., Воропай, С., Собко, Н., Гавришко, С. (2015), "Динаміка показників загальної фізичної підготовленості юних футбопістів на етапі базової підготовки", Фізичне виховання, спорт і культура здоров'я у сучасному суспільстві: збірник наукових праць, № 2(30), C. $160-164$.

17. Шевченко, А.Ю., Бойченко, С.В. (2014), "Структура і зміст процесу процесу підготовки юних футболістів на етапі початкової підготовки", Науковий часопис НПУ імені М.П. Драгоманова, Випуск 6(49), С. 147-155.

Стаття надійшла до редакції: 05.11.2019 p.

Опубліковано: 30.12.2019 р.

Аннотация. Ярослав Крайник, Вячеслав Мулик, Дарья Окунь, Святослав Коваль. Использование специальных упражнений для развития двигательных качеств и формирования технико-тактических действий защитников 13-14 лет в подготовительном периоде. Цель: разработать содержание тренировочных программ для крайних и центральных защитников с использованием специальных упражнений в соответствии с игровым амплуа и определить эффективность их использования у юных футболистов 13-14 лет. Материал и методы: в исследовании принимали участие юные футболисты 13-14 лет ФК "Арсенал" г. Харьков в количестве 10 спортсменов в течение годичного макроцикла (2018-2019). В процессе исследования использовались педагогическое наблюдение и определение количественных и качественных технико-тактических действий в течение матча, методы математической статистики. Результаты: определено влияние комплексов специальных беговых и прыжковых упражнений, которые дополнительно использовались у крайних и центральных защитников в соответствии с игровым амплуа, на количественные и качественные показатели игровой деятельности юных футболистов 13-14 лет. Выводы: полученные результаты экспериментально подтвердили эффективность применения специализированных беговых и прыжковых упражнений отдельно у крайних и центральных защитников, что повышает уровень выполнения ими технико-тактических действий.

Ключевые слова: крайние и центральные защитники, двигательные качества, игровое амплуа, технико-тактические действия, морфо-функциональные показатели.

Abstract. Yaroslav Kraynik, Vyacheslav Mulik, Daria Okun \& Svyatoslav Koval. Use of special exercises for the development of motor qualities and the formation of technical and tactical actions of defenders 13-14 years in the preparatory period. Purpose: to develop the content of training programs for the extreme and central defenders using special exercises in accordance with the game role and determine the effectiveness of their use in young football players 13-14 years old. Material \& Methods: the study involved young football players of 13-14 years old FC "Arsenal" in Kharkiv in the amount of 10 athletes during a one-year macrocycle (2018-2019). In the process of research, pedagogical observation and determination of quantitative and qualitative technical and tactical actions during the match, methods of mathematical statistics were used. Results: the influence of the complexes of special running and jumping exercises, which were additionally used by the wing back and central defenders in accordance with the game role, on the quantitative and qualitative indicators of the game activity of young football players of 13-14 years is determined. Conclusions: the results obtained experimentally confirmed the effectiveness of the use of specialized running and jumping exercises separately for the extreme and central defenders, which increases the level of their performance of technical and tactical actions.

Keywords: wing back and central defenders, motor qualities, playing role, technical and tactical actions, morpho-functional indicators.

Крайник, Я., Мулик, В., Окунь, Д., Коваль, С. (2019), "Використання спеціальних вправ для розвитку рухових якостей та формування техніко-тактичних дій захисників 13-14 років у підготовчому періоді", Слобожанський науково-спортивнии вісник, № 6(74), С. 32-36, doi: 10.15391/snsv.2019-6.005
Kraynik, Ya., Mulik, V., Okun, D. \& Koval, S. (2019), "Use of special exercises for the development of motor qualities and the formation of technical and tactical actions of defenders $13-14$ years in the preparatory period", Slobozans'kij naukovo sportivnij visnik, No. 6(74), pp. 32-36, doi:10.15391/snsv.2019-
6.005 


\section{SLOBOZANS'KIJ NAUKOVO-SPORTIVNIJ VISNIK}

\section{References}

1. Berdnikova, A.N. (2018), "Features of the technical, tactical and physical training of football players 13-14 years old", Chelovek. Sport. Meditsina, Vol. 18, No. 4, pp. 73-79. (in Russ.)

2. Daev, V.Ye. (2007), Optimizatsiya sportivnogo otbora i orientatsii futbolistov po igrovym amplua na etape uglublennoy spetsializayii: avtorefrat [Optimization of sports selection and orientation of football players by playing roles at the stage of in-depth specialization: abstract], Malakhovka. (in Russ.)

3. Yermolenko, P. \& Zaloilo, V. (2012), "Preparation of football players aged 11-15 years taking into account the game role", Teoriia $i$ metodyka fizychnoho vykhovannia i sportu, No. 1, pp. 16-22. (in Ukr.)

4. Zhurid, S.N. (2007), "Model characteristics of the technical and tactical actions of young soccer players 15 and 17 years of various game roles", Slobozans'kij naukovo-sportivnij visnik, No. 12, pp. 93-97. (in Russ.)

5. Zaychenko, A.S. \& Popov, Yu.A. (2017), "Improving the speed qualities of physical training of football players of different game roles", Fizicheskaya kultura: vospitanie, obrazovanie trenirovka, No. 5, pp. 34-36. (in Russ.)

6. Koval, S.S. \& Lebediev, S.I. (2014), "Comparative analysis of team quantitative indicators of technical and tactical actions of football players of 10-12 years during competitive activity", Slobozans 'kij naukovo-sportivnij visnik, No. 1(39), pp. 48-52. (in Ukr.)

7. Koval, S.S. (2010), "A study of the relationship of speed qualities and technical and tactical actions of young soccer players aged 8-12", Slobozans'kij naukovo-sportivnij visnik, No. 1, pp. 99-102. (in Russ.)

8. Kostyukevich, V.M. (2006), Upravlenie trenirovochnym protsessom futbolistov v godichnom tsikle podgotovki: monografiya [Management of the training process of football players in the annual training cycle], Vinnitsa. (in Russ.)

9. Mulyk, V.V. \& Krainyk, Ya.B. (2019), "Quantitative Characteristics of the Movement of Young Soccer Players During Competitive Activities during the Pre-Basic Training", Sportyvni ihry, No. 4(14), pp. 48-57, doi: 10.15391/si.2019-4.05. (in Ukr.)

10. Larin, O.S. \& Ivanov, N.V. (2016), "Features of the special physical training of young football players taking into account the game role", Uchenye zapiski universiteta imeni P.F. Lesgafta, No. 1(131), pp. 123-125. (in Russ.)

11. Lisenchuk, G.A. (2003), Upravlenie podgotovkoy futbolistov [Training Management for Football Players], Kiev. (in Russ.)

12. Lisenchuk, H., Popov, O. \& Khomenko, O. (2013), "Structure of physical fitness of football players", Teoriia i metodyka fizychnoho vykhovannia i sportu, No. 3, pp. 21-23. (in Ukr.)

13. Perevoznyk, V.I. \& Pertsukhov, A.A. (2015), "Motor activity of football players of different roles in the conditions of competitive activity", Sportyvni ihry, No. 11, pp. 143-146. (in Ukr.)

14. Pertsukhov, A.A. (2009), "Assessment of reliability of performance of technical and tactical actions by football players of 17-19 years of different playing fields", Slobozans'kij naukovo-sportivnij visnik, No. 3, pp. 123-126. (in Ukr.)

15. Pertsukhov, A.A. (2013), "Comparative characteristics of special preparedness indicators for central and extreme defenders 17-19 years old", Slobozans 'kij naukovo-sportivnij visnik, No. 2, pp. 62-67. (in Russ.)

16. Sobko, S., Voropai, S., Sobko, N. \& Havryshko, S. (2015), "Dynamics of indicators of general physical fitness of young players at the stage of basic training", Fizychne vykhovannia, sport i kultura zdorov'ia u suchasnomu suspilstvi: zbirnyk naukovykh prats, No. 2(30), pp. 160164. (in Ukr.)

17. Shevchenko, A.Yu. \& Boichenko, S.V. (2014), "Structure and content of the process of preparation of young football players at the stage of initial preparation", Naukovyi chasopys NPU imeni M.P. Drahomanova, Vypusk 6(49), pp. 147-155. (in Ukr.)

Received: 05.11.2019.

Published: 30.12 .2019

\section{Відомості про авторів / Information about the Authors}

Крайник Ярослав Богданович: Харківська державна академія фізичної культури: вул. Клочківська 99, м. Харків, 61058, Україна.

Крайник Ярослав Богданович: Харьковская государственная академия физической культуры: ул. Клочковская 99, г. Харьков, 61058, Украина.

Yaroslav Kraynik: Kharkiv State Academy of Physical Culture: street Klochkivska 99, t. Kharkiv, 61058, Ukraine.

ORCID.ORG/0000-0003-1567-8570

E-mail: yaroslavkr2014@gmail.com

Мулик В'ячеслав Володимирович: д. фіз. вих., професор; Харківська державна академія фізичної культури: вул. Клочківська 99 м. Харків, 61058, Україна.

Мулик Вячеслав Владимирович: д. физ. восп., профессор Харьковская государственная академия физической культуры: ул. Клочковская 99, г. Харьков, 61058, Украина

Vyacheslav Mulik: Doctor of Sciences (Physical Education and Sports), Professor; Kharkiv State Academy of Physical Culture: street Klochkivska 99, t. Kharkiv, 61058, Ukraine.

ORCID.ORG/0000-0002-4441-1253

E-mail: mulyk.viacheslav@gmail.com

Окунь Дар'я Олександрівна: кандидат наук з фізичного виховання і спорту, викладач кафедри олімпійського і професійного спорту; Харківська державна академія фізичної культури: 61058, м. Харків, вул. Клочківська, 99, Україна.

Окунь Дарья Александровна: кандидат наук по физическому воспитанию и спорту, преподаватель кафедры олимпийского и профессионального спорта; Харьковская государственная академия физической культуры: 61058, г.. Харьков, ул. Клочковская, 99, украина.

Daria Okun: PhD(Physical Education and Sport), Lecturer in the Department of Olympic and Professional Sports; Kharkiv State Academy of Physical Culture, 61058, Kharkiv, st. Klochkivska, 99, Ukraine.

ORCID.ORG/0000-0002-0639-5846

E-mail: dariaokun@gmail.com

Коваль Святослав Святославович: к. фіз. вих., доцент: Харківська державна академія фізичної культури: вул. Клочківська 99, Харків, 61058, Україна.

Коваль Святослав Святославович: к. физ. восп., доцент; Харьковская государственная академия физической культуры: ул. Клочковская 99, г. Харьков, 61058, украина.

Svyatoslav Koval: PhD (physical education and sport), Associate Professor; Kharkiv State Academy of Physical Culture: Klochkivska str. 99, Kharkiv, 61058, Ukraine.

ORCID.ORG/0000-0001-7140-6276

E-mail: Koval.S.S.79@gmail.ru 


\section{Алгоритм застосування засобів фізичної терапії в осіб з компресійно-ішемічними невропатіями верхньої кінцівки}

\section{Олена Бісмак}

Мета: розробити алгоритм реабілітаційних заходів в осіб з компресійно-ішемічними невропатіями верхньої кінцівки. Матеріал і методи: у дослідженні брали участь 67 хворих з компресійно-ішемічними невропатіями верхньої кінцівки, серед них було $43(64,2 \%)$ чоловіки та 24 (35,8\%) жінки. Тривалість захворювання становила від 3 до 18 місяців. Вік

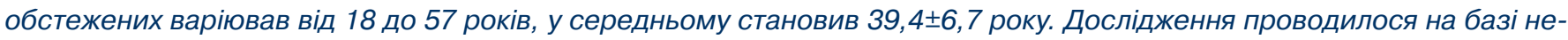
врологічного відділення та відділення фізіотерапії Київської міської клінічної лікарні № 4, м. Київ, у період з 2017 по 2019 рр. Використовували наступні методи дослідження: аналіз та узагальнення даних літературних джерел, контентаналіз медичних карт, реабілітаційне обстеження.

Результати: важливою умовою лікування тунельних невропатій $є$ комплексний підхід, який повинен мати такі складові: комплексне реабілітаційне обстеження для визначення основних реабілітаційних проблем; постановка завдань із прогнозуванням отриманого кінцевого результату; добір відповідних індивідуальних та оптимальних для кожного пацієнта засобів фізичної терапії. Розроблено алгоритм фізіотерапевтичного втручання, який включав застосування наступних заходів: кінезотерапії з нейродинамічною мобілізацією, тейпування, стимулюючого масажу, апаратної фізіотерапії, механотерапії та гідрореабілітації. Запропонований алгоритм заходів фізичної терапії відрізнявся від стандартних тим, що дав змогу сформувати цілі реабілітаційного процесу з урахуванням диференційованого підходу до вирішення проблеми реабілітації пацієнтів з компресійно-ішемічними невропатіями верхньої кінцівки з різним ступенем тяжкості розладів рухових функцій; мав комплексний, міждисциплінарний підхід до вирішення проблем пацієнтів з даною патологією.

Висновки: розробка алгоритму фізіотерапевтичного втручання для осіб з компресійно-ішемічними невропатіями верхньої кінцівки є актуальною проблемою з огляду на те, що компресійно-ішемічні невропатії верхньої кінцівки часто призводять до зниження якості життя людини та тривалої втрати працездатності. При розробці алгоритму реабілітаційних заходів необхідно враховувати: індивідуальні особливості функціонального стану пацієнтів при даній патології, наявність та вираженість рухових та чутливих порушень, які залежать від того, який саме нерв руки уражений (серединний, ліктьовий чи променевий), характеру ураження, вік, професійну діяльність та потреби пацієнта.

Ключові слова: невропатія, верхня кінцівка, фізична терапія, алгоритм, консервативне лікування.

\section{Вступ}

Захворювання периферичної нервової системи є великою медичною, економічною та соціальною проблемою для людства. Статистика вказує не тільки на збільшення неврологічних захворювань, але й на ранній ї початок $[1 ; 4 ; 9]$. У зв'язку з цим в усьому світі значно збільшується роль неврологічної реабілітації, направленої на відновлення високої якості життя, яке було порушено у результаті ураження периферичної нервової системи.

Сучасний етап фізичної терапії можна визначити як етап комплексного підходу до відновлення, кінцевою метою якого $є$ повернення пацієнтів у суспільство, до трудової та соціальної активності. Пошук нових методів лікування та відновлення функціонального стану верхньої кінцівки при периферичних невропатіях проводиться за різними напрямками. Одним із них $є$ удосконалення методів нейрохірургічного лікування [6; 13; 15], впровадження ортопедичних операцій [3]. 3 метою стимуляції регенерації використовують засоби (у тому числі медикаментозні), які покращують мікроциркуляцію нерву та провідність по нервовому стовбуру, - довготривалу хронічну електростимуляцію [15], великий арсенал методів апаратної фізіотерапії [5; 7; 8].

Проте результати лікування ушкоджень периферич- них нервів верхньої кінцівки у широкій клінічній практиці не завжди бувають задовільними у зв'язку з тим, що часто не реалізуються наявні можливості для реабілітації подібних постраждалих. Вказані лікувальні засоби направлені здебільшого на відновлення структури та функції ушкодженого нерву верхньої кінцівки, активність та участь пацієнтів у повсякденному житті при даній патології не завжди враховуються у процесі лікування, що суперечить основним положенням Міжнародної класифікації функціонування, обмежень життєдіяльності та здоров'я, яку вже певний час впроваджує в діяльність працівників медичної, соціальної та освітньої сфер МОЗ України.

Необхідно відзначити, що роботи за даною проблемою носять поодинокий характер, чіткого алгоритму реабілітаційних заходів при даній патології ще не розроблено. Комплексного, науково обґрунтованого підходу до вирішення проблеми реабілітації осіб з периферичними невропатіями верхньої кінцівки з урахуванням виду лікування (консервативне чи оперативне), перебігу захворювання, впливу реабілітаційних заходів на якість життя пацієнтів на даний момент у доступній літературі не виявлено.

Мета дослідження: розробити алгоритм реабілітаційних заходів в осіб з компресійно-ішемічними невропатіями верхньої кінцівки. 


\section{SLOBOZANS'KIJ NAUKOVO-SPORTIVNIJ VISNIK}

\section{Матеріал і методи дослідження}

У дослідженні брали участь 67 хворих з компресійноішемічними невропатіями верхньої кінцівки, серед них було 43 (64,2\%) чоловіки та 24 (35,8\%) жінки. Тривалість захворювання становила від 3 до 18 місяців. Вік обстежених варіював від 18 до 57 років, у середньому становив $39,4 \pm 10,7$ року. Дослідження проводилося на базі неврологічного відділення та відділення фізіотерапії Київської міської клінічної лікарні № 4, м. Київ, у період з 2017 по 2019 рр. Ми використовували наступні методи дослідження: аналіз та узагальнення даних літературних джерел, контент-аналіз медичних карт, реабілітаційне обстеження.

\section{Результати дослідження}

Мультидисциплінарна реабілітація на сьогодні є ключовим підходом у застосуванні медичних та реабілітаційних заходів при різних захворюваннях. Такий підхід має принципове значення у відновленні рухових функцій, активності та участі пацієнтів 3 компресійно-ішемічними невропатіями верхньої кінцівки. Цей цілісний підхід підтримується Міжнародною класифікацією функціонування, обмежень життєдіяльності та здоров'я Всесвітньої організації охорони здоров'я, яка є єдиною основою мультидисциплінарного підходу [2; 4].

Відомо, що важливою умовою лікування тунельних невропатій є комплексний підхід, який повинен мати такі складові:

а) комплексне реабілітаційне обстеження для визначення основних реабілітаційних проблем

б) постановка завдань із прогнозуванням отриманого кінцевого результату;

в) добір відповідних індивідуальних та оптимальних для кожного пацієнта засобів фізичної терапії (рис. 1).

Основними принципами фізичної терапії при даній патології є:

- партнерство лікаря і хворого;

- різнобічності зусиль або комплексності;

- єдності психосоціальних і біологічних методів;

- безперервності та індивідуалізації лікувальних впливів [14].

Реабілітаційне обстеження включало:

1. Опитування пацієнта, визначення цілей фізичної терапії та запитів пацієнта.

2. Фізикальне обстеження: огляд пацієнта; визначення діапазону руху в ураженій верхній кінцівці; тести на чутливість.

3. Рухове обстеження: мануально-м'язове тестування; візуально-аналогова шкала болю; провокаційні тести: Фалена, Тінеля.

4. Функціональна оцінка: за допомогою Бостонського опитувальника DASH визначались основні функціональні відхилення, і виходячи з цього ставились цілі на рівні діяльності та участі у SMART форматі за МКФ.

На етапі планування процесу реабілітації та постановки цілей ми враховували результати обстеження пацієнтів та їх потреби. Цілі реабілітаційних заходів визначалися у залежності від професійної діяльності, повсякденного способу життя та дозвілля.

Перебіг невропатій периферичних нервів верхньої кінцівки нерву має певні періоди захворювання, кожному з яких характерний відповідний функціональний стан

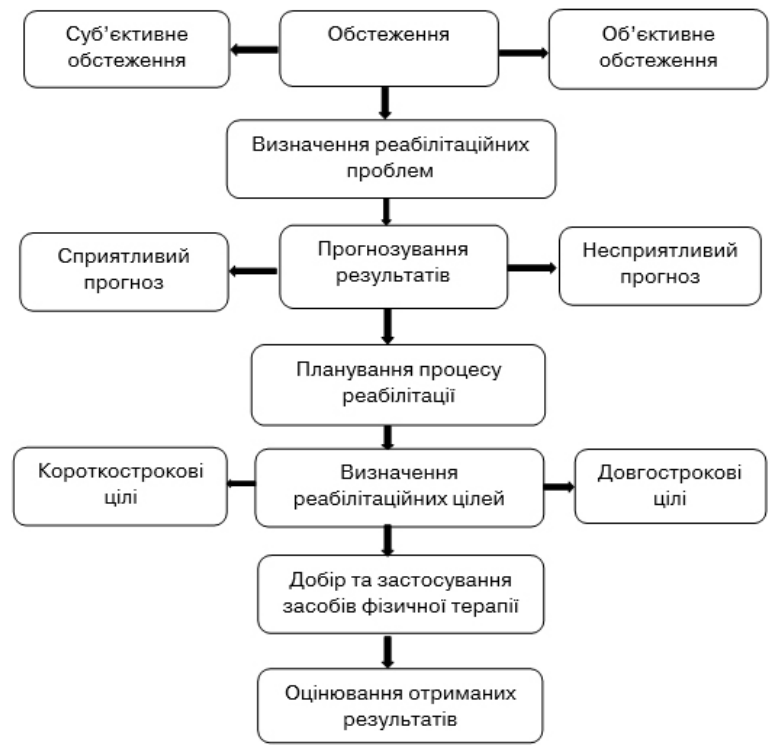

Рис. 1. Схема послідовності дій у процесі фізичної терапії при компресійно-ішемічних невропатіях верхньої кінцівки

ушкодження (гострий, підгострий, ремісії, одужання) та застосування заходів фізичної терапії.

Фізіотерапевтичні заходи ми розпочинали відразу ж після моменту встановлення діагнозу, оскільки від цього багато в чому залежить подальший перебіг процесу відновлення.

Цілями фізичної терапії є:

1) максимально можливе відновлення порушених функцій зап'ястка та кисті;

2) покращення еластичних властивостей суглобовозв'язкового апарату;

3) відновлення сили м'язів кисті і ураженої верхньої кінцівки;

4) покращення сенсо-моторного контролю та пропріоцептивної чутливості;

5) адаптація до побутових і професійних навантажень;

6) відновлення загальної працездатності на основі максимального відновлення функціональних можливостей верхньої кінцівки.

Розроблений алгоритм заходів фізичної терапії враховував:

- методологічні підходи Міжнародної класифікації функціонування під час встановлення напряму реабілітаційного процесу;

- засади формування індивідуальних смарт-цілей (смарт-завдань) для пацієнтів;

- індивідуальні потреби пацієнтів та активність стилю життя;

- рухові та сенсорні порушення та зміни в психоемоційному стані, що мають вплив на прогноз відновлення.

Підґрунтям для розробки алгоритму реабілітаційних заходів слугували наукові, організаційні, змістові та нормативні основи, необхідність застосування диференційованого підходу з урахуванням рухових та чутливих порушень, які залежать від того, який саме нерв руки уражений (серединний, ліктьовий чи променевий), характеру ураження та індивідуальних особливостей функціонального стану пацієнтів.

Найбільш часто уражаються серединний нерв (синдром карпального каналу) та ліктьовий нерв (синдром ку- 
бітального каналу), рідше спостерігається синдром компресії променевого нерву. При первинному обстеженні у 39 $(58,2 \%)$ хворих було діагностовано синдром карпального каналу, у 19 (28,4\%) осіб - синдром кубітального каналу, у 9 (13,43\%) хворих - синдром компресії променевого нерву ("синдром спірального каналу").

Відомо, що при синдромі карпального каналу кисть звисає, розгинання її та основних фаланг пальців неможливе, пальці звисають, неможливі відведення великого пальця. Чутливі розлади виражені слабше, спостерігається набряк кисті.

При пошкодженні серединного нерву відсутні згинання 1, 2 та частково 3 пальців, неможливі повороти кисті, протиставлення і відведення 1 пальця, який знаходиться в одній площині з іншими пальцями ("мавп'яча лапа"). Зниження всіх видів чутливості на долонній стороні кисті і кінцевих фалангах 2, 3, 4 пальців на тильній стороні. Характерні болі і виражені вегетативні прояви.

При компресійному ураженні ліктьового нерву призводить до порушення згинання 4, 5 пальців, приведення і розведення всіх пальців; 5, 4 і частково 3 пальці розігнуті в основних та зігнуті у середніх фалангах ("пазуриста лапа"). Виражена атрофія міжкісткових м'язів. Чутливість знижена на ліктьовий половині кисті, V і половині IV пальця $[5 ; 12]$.

Алгоритм фізіотерапевтичного втручання передбачав застосування наступних заходів: кінезотерапії з нейродинамічною мобілізацією, тейпування, стимулюючого масажу, апаратної фізіотерапії, механотерапії та гідрореабілітації (рис. 2). Запропонований алгоритм заходів фізичної терапії відрізнявся від стандартних програм тим, що дав змогу сформувати цілі реабілітаційного процесу з урахуванням диференційованого підходу до вирішення проблеми реабілітації пацієнтів з компресійно-ішемічними невропатіями верхньої кінцівки з різним ступенем тяжкості розладів рухових функцій; мав комплексний, міждисциплінарний підхід до вирішення проблем пацієнтів 3 даною патологією. Застосування засобів фізичної терапії розраховано на 30 днів.

Кінезотерапія сприяє відновленню функціональних показників зап'ястка та кисті, зміцненню м'язів ураженої верхньої кінцівки, збільшенню амплітуди рухів, збільшенню витривалості. Основу кінезотерапії складають різні форми руху - терапевтичні вправи [7; 8]. Терапевтичні вправи дозволяють реалізувати більшість цілей реабілітації при невропатіях верхньої кінцівки. Ми підбирали вправи з урахуванням полегшеного їх виконання (початкове положення, ковзаючі площини тощо); локалізації пошкодження; простоти або складності рухів (елементарні,

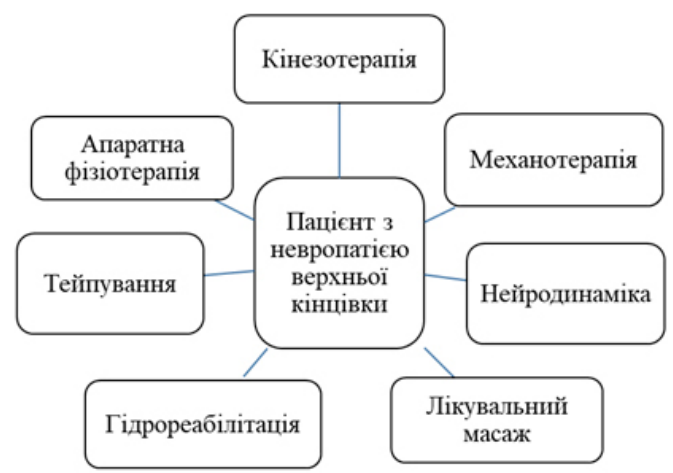

Рис. 2. Складові алгоритму реабілітаційних заходів при компресійно-ішемічних невропатіях співдружності, на координацію та ін.); ступеня активності (пасивні, пасивно-активні, активні); відновлення або розвитку необхідних рухових навичок. На початку курсу реабілітації ми використовували пасивні, пасивно-активні, ідеомоторні вправи. При покращенні стану хворих заняття доповнювалися ізометричними вправами - статичне почергове напруження і розслаблення м'язів ураженої області. Напруження зростало поступово і досягало максимального зусилля на 6-7 секунді. Період відпочинку після кожної вправи близько 1,5-2 хвилин.

Статичне напруження дозволяє спрямовано акцентувати і продовжувати момент максимального м'язового напруження, що дає можливість вибірково впливати на різні м'язові групи. Комплекс становив 4-6 вправ, що виконувались з різних вихідних положень - сидячи, лежачи на спині, на животі, на боці і проводився 2-3 рази на день протягом 10-15 хвилин. Відновлення сили м'язів ураженої області досягалось за допомогою силових вправ, вправ з опором, додаткових обтяжень (еспандерів, гантелей). Використовувались в основному терапевтичні силові вправи.

Перед початком занять визначалися показники активних і пасивних рухів, виконуваних пацієнтом. Показники пасивних рухів, зазвичай, перевищували показники активних рухів. Чим більше різниця між цими показниками, тим більшою є резервна розтяжність, а отже, і можливість збільшення амплітуди активних рухів.

Для закріплення досягнутого об'єму рухів використовувалось позиціонування з використанням спеціальних лангет або ортеза. Мінімальний час фіксації 10 хвилин з поступовим збільшенням до 40-60 хвилин. При проведенні занять кінезотерапії також використовувались загально-розвивальні вправи, дихальні вправи, коригувальні вправи, вправи з предметами і на розслаблення. Заняття проводились щодня або через день, тривалість залежала від стадії захворювання: 15-25 хв, 25-40 хв.

Із нейродинамічних технік ми застосовували нейродинамічне тестування і нейромобілізацію. До першочергових завдань нейромобілізації при компресійно-ішемічних невропатіях верхньої кінцівки відносяться: усунення больового синдрому; запобігання набряку нерву і периневральних тканин; стимулювання провідності нерву та регенерації нервових волокон; поліпшення місцевого і загального крово- та лімфообігу; попередження утворення рубців на місці пошкодження; запобігання або усунення трофічних розладів, тугорухливості у суглобах, контрактур та інших змін, що перешкоджають відновленню рухів верхньої кінцівки; компенсування втрачених рухів подібними (при повній і стійкій реакції переродження) за рахунок синергічних м'язів, що зберегли іннервацію.

Перед початком діагностичної частини рекомендується проведення електронейроміографії з метою визначення параметрів проведення імпульсу по нервових волокнах. Нейродинамічне тестування виконувалося за суворими алгоритмами і складалося з рухів верхніми кінцівками у певних напрямках і під певним кутом за допомогою фізичного терапевта [19].

Якщо за результатами нейродинамічного і мануальном'язового тестування не виявлялося протипоказань до застосування нейромобілізації, ми розпочинали нейродинамічні вправи. Виконання технік неромобілізації здійснюється шляхом поетапного застосування згинальних, розгинальних рухів та ротації за допомогою рук фізичного терапевта за чітко заданими орієнтирами [20; 21]. Проводиться мобілізація рухів нерву вгору-вниз, ковзання по 


\section{SLOBOZANS'KIJ NAUKOVO-SPORTIVNIJ VISNIK}

довжині каналу, іноді розтягнення до повного відновлення. Хворі займалися терапевтичними вправами з елементами нейромобілізації щодня по 30-40 хв.

Важливе місце серед реабілітаційних заходів при компресійно-ішемічних невропатіях займає кінезіотейпування [17; 18]. Кінезіотейпування використовується для усунення больового синдрому, поліпшення кровообігу, активації пропріоцептивної чутливості, підвищення м'язового тонусу, збільшення діапазону активних рухів в ураженій верхній кінцівці.

Накладення кінезіологічного тейпа ми проводили за певною схемою залежно від наявних рухових порушень. Так, при синдромі карпального каналу проводилося тейпування кисті, променевозап'ястного суглоба і передпліччя, використовувалися різні види тейпів - І-тейп таҮ-тейп [17; 18]. При синдромі кубітального каналу аплікація виконувалася за допомогою І-тейпа по внутрішній поверхні кисті і передпліччя від IV-V пальця до медіального надвиростка плечової кістки через променевозап'ясний суглоб, а також по зовнішній поверхні кисті і передпліччя в напрямку до латерального надвиростка плечової кістки.

Лікувальний масаж проводився 3 метою стимуляції паретичних м'язів ураженої кінцівки переважно на хворих ділянках руки, іноді на симетричних кінцівках [8; 9]. При невропатії ліктьового нерву проводився масаж передпліччя, плеча та ліктьового суглобу, при ураженні променевого нерву - передпліччя, зап'ястя, кисть, при невропатії серединного нерву - зап'ястя, кисть та пальці. Для масування даних областей застосовувалися такі прийоми погладжування, розтирання, розминання та струшування. Масаж проводився через день по 20-30 хвилин.

Механотерапію ми використовували для збільшення гнучкості і амплітуди рухів, поліпшення координації рухів, підвищення сенсо-моторного контролю та пропріоцептивної чутливості, збільшення сили м'язів [10; 11]. Застосовували реабілітаційний тренажер ARTROMOT ®-F, який має розширений діапазон рухів у різних площинах. Точне регулювання амплітуди рухів у суглобі дозволяє пацієнтові практично не відчувати біль при виконанні вправ на тренажері. 3 кожним сеансом амплітуда рухів поступово збільшувалась, за можливості до повного відновлення суглоба. Методика проведення механотерапії для пацієнтів з компресійно-ішемічними невропатіями руки будувалась 3 урахуванням біологічних і фізіологічних змін організму пацієнта, стадії захворювання і рівня ушкодження, часу, що пройшов після перших клінічних ознак захворювання. Заняття проводились через день, тривалість 20-30 хвилин.

Для усунення стійкого обмеження амплітуди рухів в суглобах кисті і пальців, зниження сили м'язів, що призводять в сумі до порушення пальцевого захоплення втрати працездатності, використовувались пасивні і активні вправи у воді (гідрореабілітація) [7; 8]. Велика увага приділялась застосуванню вправ на тренування основних функцій руки: захват, утримання, переміщення предметів різної щільності. Вправи на захват пружних предметів у полегшених умовах водного середовища допомагають правильно орієнтувати напрям рухів, що здійснюються пальцями, завдяки цілеспрямованому характеру рухів легкій протидії використовуваного предмета (губки, гу- мового м'яча тощо).

У зв'язку з фіксованим характером рухових розладів пасивні вправи у воді виконуються за загальними методичними правилами (повільний темп руху, поступово наростаюче зусилля, нетривала затримка руху в крайньому положенні). Для відновлення робочого (циліндричного) пальцевого захоплення шляхом пасивного згинання всіх пальців домагаються достатньої амплітуди згинання в п'ястно-фалангових суглобах. Закріпленню досягнутого пасивними вправами обсягу рухів у суглобах допомагає подальше виконання вільних активних рухів у воді і з самодопомогою, а також вправ у воді на захват і стискання м'яча. Заняття проводились через день, тривалість залежала від стадії захворювання: 15-20 хв, 25-40 хв.

у пацієнтів з ураженням периферичних нервів руки найбільш частими симптомами, які вимагають призначення фізіотерапевтичних процедур, є зниження м'язового тонусу, больовий синдром, рухові і трофічні розлади [16]. 3 цією метою ми застосовували: постійне магнітне поле на м'язи-згиначі руки і розгиначі ноги, 20-30 мТл, 15-20 хвилин, через день, 7-10 процедур; точковий масаж за збуджувальною методикою, кожен день або через день;

Стимулююча фізіотерапія (показана при рухових і трофічних порушеннях): електростимуляція слабких м'язів синусоїдальними модульованими струмами у випрямленому режимі з модуляціями типу "посилка-пауза" при частоті 100 Гц, глибині 75-100\%, відношенні тривалості посилок струму і паузи як 1:2, по 2-3 хвилини на одне поле, загальна тривалість процедури 8-10 хвилин, 15-20 процедур, щодня. Доцільним є використання двополюсної методики з розташуванням однакових за площею електродів в обох кінцях тренованих антагоністів гіпотонічних м'язів. 3 метою електростимуляції можна використовувати апарати багатоканальної стимуляції типу "Міотонія". Важливий правильний підбір параметрів стимуляції для уникнення перевтоми гіпотонічного м'яза.

\section{Висновки / Дискусія}

Розробка алгоритму фізіотерапевтичного втручання для осіб з компресійно-ішемічними невропатіями верхньої кінцівки $є$ актуальною проблемою з огляду на те, що компресійно-ішемічні невропатії верхньої кінцівки часто призводять до зниження якості життя людини та тривалої втрати працездатності.

При розробці алгоритму реабілітаційних заходів необхідно враховувати індивідуальні особливості функціонального стану пацієнтів, наявність та вираженість рухових та чутливих порушень, які залежать від того, який саме нерв руки уражений (серединний, ліктьовий чи променевий), характер ураження, вік, професійну діяльність та потреби пацієнта. Основними реабілітаційними заходами при даній патології є: кінезотерапія з нейродинамічною мобілізацією, тейпування, лікувальний масаж, апаратна фізіотерапія, механотерапія та гідрореабілітація.

Перспективи подальших досліджень полягають у визначенні ефективності розробленого алгоритму реабілітаційних заходів при даній патології та розробці рекомендацій для домашньої реабілітації.

Конфлікт інтересів. Автор заявляє, що немає конфлікту інтересів, який може сприйматися таким, що може завдати шкоди неупередженості статті. Джерела фінансування. Ця стаття не отримала фінансової підтримки від державної, громадської або комерційної організацій.

Бісмак, О. (2019), "Алгоритм застосування засобів фізичної терапії в осіб з компресійно-ішемічними невропатіями верхньої кінцівки", Слобожанський науково-спортивний вісник, № 6(74), C. 37-42, doi: 10.15391/snsv.2019-6.006
Bismak, O. (2019), "Algorithm for the use of physical therapy in patients with compression-ischemic neuropathies of the uppe limb", Slobozans'kij naukovo-sportivnij visnik, No. 6(74), pp. 37 42, doi:10.15391/snsv.2019-6.006 


\section{СЛОБОЖАНСЬКИЙ НАУКОВО-СПОРТИВНИЙ ВІСНИК}

\section{Список посилань}

1. Бахтерева, Е.В. (2017), Компрессионные периферические невропатии верхних конечностей: роль производственных факторов, ранняя диагностика и лечение: автореф. дис. д-ра мед. наук, Екатеринбург.

2. Богов, А.А., Васильев, М.В., Филимонычев, Д.А. (2009), "Туннельные поражения нервных стволов верхней конечности", Казанский медицинский журнал, Т. 90, № 4, С. 593-597.

3. Гайович, В.В., Страфун, С.С., Борзих, Н.О., Гайко, О.Г., Борзих О.В., Цимбалюк, Я.В. (2018), "Пріоритетні напрями хірургічного лікування поранених з ушкодженням периферичних нервів верхньої кінцівки при поліструктурних травмах", Травма, Т. 19, № 3.

4. Голубев, В.Л., Меркулова, Д.М., Орлова, О.Р. (2017), "Туннельные синдромы руки", Русский медицинский журнал, № 2.

5. Евтушенко, С.К., Евтушевская, А.Н., Марусиченко, В.В. (2015), "Туннельные невропатии. Трудности диагностики и терапии", Международный неврологический журнал, № 1 (71), С. 25-30.

6. Зозуля, Ю.П., Третяк, І.Б., Сапон, М.А. (2013), "Відновне хірургічне лікування наслідків ушкодження довгих гілок плечового сплетення з використанням тривалої електростимуляції", Український нейрохірургічний журнал, № 2, C. 19-22, peжим доступу: http:// nbuv.gov.ua/UJRN/Unkhj_2013_2_5.

7. Исанова, В.А. (2012), Кинезотерапия в реабилитации неврологических больных с двигательными нарушениями, Казань.

8. Кадыков, А.С. (2018), Реабилитация неврологических больных, Москва.

9. Львов, С.Е. (2007), Реабилитация больных с повреждениями кисти: дис... д-ра мед. наук, Нижний Новгород.

10. Попадюха, Ю.А., Пеценко, Н.І. (2009), "Технічні засоби для відновлення рухових функцій верхніх кінцівок людини", Науковий часопис НПУ ім. М. П. Драгоманова, Серія 5, Вип. 14, С. 165-168.

11. Попадюха, Ю.А. (2014), "Реабилитационные тренажеры в физической реабилитации после артроскопической реконструкции ротаторной манжеты плеча спортсменов", Сб. материалов III Междунар. науч.-техн. конф., Минск, 13-14 февраля, С. 62-66.

12. Рассел, С.М. (2017), Диагностика повреждения периферических нервов, Москва.

13. Третяк, І.Б. (2007), "Використання тривалої електростимуляції при пошкодженні периферійних нервів та сплетень", Український нейрохірургічний журнал, № 2, С. 58-61.

14. Снытников, К.Ю., Халяпин, Д.В., Бельчинский, В.В., Плетнев, А.В., Кочукова, М.В. (2016), "Лечение больных при повреждении нервов", Молодой ученый, № 5 (109), С. 234-236.

15. Цимбалюк, Ю.В. (2014), Відновне нейрохірургічне лікування ушкоджень периферичних нервів із застосуванням довготривалої електростимуляції: автореф. дис. д-ра мед. наук, Київ.

16. Широков, В.А. (2015), "Импульсная электромагнитная стимуляция в реабилитации больных с компрессионно-ишемическими нейропатиями верхних конечностей", Восстановительная медицина и реабилитация: тез. докл. /l междун. Конгресса, Москва, С. 9-10.

17. Ali, R.R. (2013), "Influence of kinesio tape in treating carpal tunnel syndrome", Journal of Medical Science and Clinical Research, Vol. 1, No. 1. pp. 1-9.

18. Clark, G.L. (2017), Hand rehabilitation: a practical guide, Churchill Livingstone, New York

19. Coppieters, M.W., Hough, A.D. \& Dilley, A. (2009), "Different nerve-gliding exercises induce different magnitudes of median nerve longitudinal excursion: an in vivo study using dynamic ultrasound imaging", J. Orthop Sports Phys Ther., 39(3), pp. 164-1671.

20. Wilbourn, A.J. (2005), "Upper limb neuropathies: Long thoracic, suprascapular, axillary, musculocutaneuos, radial, ulnar, and medial antebrachial cutaneous", Peripheral Neuropathy, Elsevier, Philadelphia, pp. 1463-1486.

21. Wolny, T.A., Shacklock, M., Linek, P. \& Myśliwiec, A. (2017), "Efficacy of Manual Therapy Including Neurodynamic Techniques for the Treatment of Carpal Tunnel Syndrome: A Randomized Controlled Trial", Journal of manipulative and physiological therapeutics, No. 40(4), doi: 10.1016/j.jmpt.2017.02.004

Стаття надійшла до редакції: 07.11.2019 р.

Опубліковано: 30.12.2019 р.

Аннотация. Елена Бисмак. Алгоритм применения средств физической терапии у лиц с компрессионноишемическими невропатиями верхней конечности. Цель: разработать алгоритм реабилитационных мероприятий у лиц с компрессионно-ишемическими невропатиями верхней конечности. Материал и методы: в исследовании принимали участие 67 больных с компрессионно-ишемической невропатией верхней конечности, среди которых было 43 (64,2\%) мужчины и 24 (35,8\%) женщины. Длительность заболевания составляла от 3 до 18 месяцев. Возраст обследованных варьировал от 18 до 67 лет, в среднем 42,3土9,4 года. Исследование проводилось на базе неврологического отделения и отделения физиотерапии Киевской городской клинической больницы № 4 г. Киева в период с 2017 по 2019 годы. Использовали следующие методы исследования: анализ и обобщение данных литературных источников, контент-анализ медицинских карт, реабилитационное обследование. Результаты: важным условием лечения туннельных невропатий является комплексный подход, который должен иметь следующие составляющие: комплексное реабилитационное обследование для определения основных реабилитационных проблем; постановка задач с прогнозированием полученного конечного результата; подбор соответствующих индивидуальных и оптимальных для каждого пациента средств физической терапии. Разработан алгоритм физиотерапевтического вмешательства, включающий применение следующих мероприятий: кинезитерапию с нейродинамической мобилизацией, тейпирование, стимулирующий массаж, аппаратную физиотерапию, механотерапию и гидрореабилитацию. Предложенный алгоритм мероприятий физической терапии отличался от стандартных программ тем, что позволил сформулировать цели реабилитационного процесса с учетом дифференцированного подхода к решению проблемы реабилитации пациентов с компрессионно-ишемическими невропатиями верхней конечности с разной степенью тяжести расстройств двигательных функций; имел комплексный, междисциплинарный подход к решению проблем пациентов с данной патологией. Выводы: разработка алгоритма физиотерапевтического вмешательства для лиц с компрессионноишемическими невропатиями верхней конечности является актуальной проблемой ввиду того, что компрессионно-ишемические невропатии верхней конечности часто приводят к снижению качества жизни пациента и длительной потере трудоспособности. При разработке алгоритма реабилитационных мероприятий необходимо учитывать: индивидуальные особенности функционального состояния пациентов при данной патологии, наличие и выраженность двигательных и чувствительных нарушений, которые зависят от того, какой именно нерв руки пораженный (срединный, локтевой или лучевой), характер поражения, возраст, профессиональную деятельность и потребности пациента.

Ключевые слова: невропатия, верхняя конечность, физическая терапия, алгоритм, консервативное лечение

Abstract. Olena Bismak. Algorithm for the use of physical therapy in patients with compression-ischemic neuropathies of the upper limb. Purpose: to develop an algorithm of rehabilitation measures in people with compression-ischemic neuropathies of the upper limb. Material \& Methods: the study involved 67 patients with compression-ischemic neuropathy of the upper limb, among whom were 43(64.2\%) men and 24(35.8\%) women. The duration of the disease ranged from 3 to 18 months. The age of the examined varied from 18 to 67 years, on average 42,3 $\pm 9,4$ years. The study was conducted on the basis of the neurological department and the physiotherapy department of the Kiev city clinical hospital No. 4 of Kyiv in the period from 2017 to 2019. We used the following research methods: analysis and synthesis of literature data, content analysis of medical records, rehabilitation examination. Results: an important condition for the

Бісмак, О. (2019), "Алгоритм застосування засобів фізичної терапії в осіб з компресійно-ішемічними невропатіями верх(1) 6(74), C. 37-42, doi: 10.15391/snsv.2019-6.006
Bismak, O. (2019), "Algorithm for the use of physical therapy in patients with compression-ischemic neuropathies of the upper limb", Slobozans'kij naukovo-sportivnij visnik, No. 6(74), pp. 37 42, doi:10.15391/snsv.2019-6.006 


\section{SLOBOZANS'KIJ NAUKOVO-SPORTIVNIJ VISNIK}

treatment of tunnel neuropathies is an integrated approach, which should have the following components: a comprehensive rehabilitation examination to determine the main rehabilitation problems; statement of tasks with prediction of the final result; selection of appropriate individual and optimal physical therapy means for each patient. An algorithm of physiotherapeutic intervention has been developed, including the use of the following measures: kinesitherapy with neurodynamic mobilization, taping, stimulating massage, instrumental physiotherapy, mechanotherapy and hydrotherapy. The proposed algorithm of physical therapy measures differed from standard programs in that it allowed to formulate the goals of the rehabilitation process taking into account a differentiated approach to solving the problem of rehabilitation of patients with compression-ischemic neuropathies of the upper limb with varying severity of motor function disorders; had a comprehensive, multidisciplinary approach to solving the problems of patients with this pathology. Conclusions: the development of an algorithm of physiotherapeutic intervention for people with compression-ischemic neuropathies of the upper limb is an urgent problem due to the fact that compression-ischemic neuropathies of the upper limb often lead to a decrease in the patient's quality of life and long-term disability. When developing an algorithm of rehabilitation measures, it is necessary to take into account: individual features of the functional state of patients with this pathology, the presence and severity of motor and sensory disturbances, which depend on which particular nerve of the arm is affected (median, ulnar or radiation), the nature of the lesion, age, professional activity and patient needs.

Keywords: neuropathy, upper limb, physical therapy, algorithm, conservative treatment.

\section{References}

1. Bakhtereva, E.V. (2017), Kompressionnye perifericheskie nevropatii verkhnikh konechnostey: rol proizvodstvennykh faktorov, rannyaya diagnostika i lechenie: avtoref. dis. $d$-ra med. nauk [Compression peripheral neuropathies of the upper extremities: the role of production factors, early diagnosis and treatment: Dr. Med. Sciences thesis abstract], Yekaterinburg. (in Russ.)

2. Bogov, A.A., Vasiliev, M.V. \& Filimonychev, D.A. (2009), "Tunnel lesions of the nerve trunks of the upper limb", Kazanskiy meditsinskiy zhurnal, Vol. 90, No. 4, pp. 593-597. (in Russ.)

3. Gayovich, V.V., Strafun, S.S., Borzikh, N.O., Gayko, O.G., Borzikh O.V. \& Tsymbalyuk, Y.V. (2018), "Priority of direct surgical treatment of injured wounds to the peripheral nerves of the upper end in case of structural injuries", Travma, Vol. 19, No. 3. (in Ukr.)

4. Golubev, V.L., Merkulova, D.M. \& Orlova, O.R. (2017), "Tunnel Syndromes of the Hand", Russkiy meditsinskiy zhurnal, No. 2. (in Russ.)

5. Evtushenko, S.K., Evtushevskaya, A.N. \& Marusichenko, V.V. (2015), "Tunnel neuropathies. Difficulties in diagnosis and therapy", Mezhdunarodnyy nevrologicheskiy zhurnal, No. 1 (71), pp. 25-30. (in Russ.)

6. Zozulya, Yu.P., Tretyak, I.B. \& Sapon, M.A. (2013), "The International Journal of Hearing of the Gossip of the Shoulder Gossip from the Victoria Trivial Electric Stimulation", Ukraïnskiy neyrokhirurgichniy zhurnal, No. 2, pp. 19-22, available at: http://nbuv.gov.ua/UJRN/ Unkhj_2013_2_5. (in Ukr.)

7. Isanova, V.A. (2012), Kinezoterapiya $v$ reabilitatsii nevrologicheskikh bolnykh $s$ dvigatelnymi narusheniyami [Kinesitherapy in the rehabilitation of neurological patients with motor disorders], Kazan. (in Russ.)

8. Kadykov, A.S. (2018), Reabilitatsiya nevrologicheskikh bolnykh [Rehabilitation of Neurological Patients], Moscow. (in Russ.)

9. Lviv, S.E. (2007), Reabilitatsiya bolnykh s povrezhdeniyami kisti: dis... d-ra med. nauk [Rehabilitation of patients with hand injuries: Dr. Med. Sciences dis.], Nizhny Novgorod. (in Russ.)

10. Popadyukha, Yu.A. \& Petsenko, N.I. (2009), "Technological Awareness for the Rukhovih Functionality of the Upper Kinzivok People", Naukoviy chasopis NPU im. M. P. Dragomanova, Seriya 5, V. 14, pp. 165-168. (in Ukr.)

11. Popadyukha, Yu.A. (2014), "Rehabilitation simulators in physical rehabilitation after arthroscopic reconstruction of athletes' rotator cuff", Sat. materials III International scientific and technical conf., Minsk, February 13-14, pp. 62-66. (in Russ.) Russ.)

2. Russell, S.M. (2017), Diagnostika povrezhdeniya perifericheskikh nervov [Diagnosis of peripheral nerve damage], Moscow. (in

13. Tretyak, I.B. (2007), "Using of electrical stimulation in the case of peripheral nerves and gossip", Ukraïnskiyneyrokhirurgichniy zhurnal, No. 2, pp. 58-61. (in Ukr.)

14. Snytnikov, K.Yu., Khalyapin, D.V., Belchinsky, V.V., Pletnev, A.V. \& Kochukova, M.V. (2016), "Treatment of patients with nerve damage", Molodoy uchenyy, No. 5 (109), pp. 234-236. (in Russ.)

15. Tsymbalyuk, Yu.V. (2014), Vidnovne neyrokhirurgichne likuvannya ushkodzhen periferichnikh nerviv iz zastosuvannyam dovgotrivaloï elektrostimulyatsii: avtoref. dis. $d$-ra med. nauk [Restorative neurosurgical treatment of peripheral nerve damage with the use of long-term electrical stimulation: Dr. Med. Sciences thesis abstract], Kiev. (in Ukr.)

16. Shirokov, V.A. (2015), "Pulse electromagnetic stimulation in the rehabilitation of patients with compression-ischemic neuropathies of the upper extremities", Restorative medicine and rehabilitation: abstract. doc. II int. Congress, Moscow, pp. 9-10. (in Russ.)

17. Ali, R.R. (2013), "Influence of kinesio tape in treating carpal tunnel syndrome", Journal of Medical Science and Clinical Research, Vol. 1, No. 1. pp. 1-9.

18. Clark, G.L. (2017), Hand rehabilitation: a practical guide, Churchill Livingstone, New York.

19. Coppieters, M.W., Hough, A.D. \& Dilley, A. (2009), "Different nerve-gliding exercises induce different magnitudes of median nerve longitudinal excursion: an in vivo study using dynamic ultrasound imaging", J. Orthop Sports Phys Ther., 39(3), pp. 164-1671.

29. Wilbourn, A.J. (2005), "Upper limb neuropathies: Long thoracic, suprascapular, axillary, musculocutaneuos, radial, ulnar, and medial antebrachial cutaneous", Peripheral Neuropathy, Elsevier, Philadelphia, pp. 1463-1486.

21. Wolny, T.A., Shacklock, M., Linek, P. \& Myśliwiec, A. (2017), "Efficacy of Manual Therapy Including Neurodynamic Techniques for the Treatment of Carpal Tunnel Syndrome: A Randomized Controlled Trial", Journal of manipulative and physiological therapeutics, No. 40(4), doi: 10.1016/j.jmpt.2017.02.004.

Received: 07.11.2019

Published: 30.12 .2019

\section{Відомості про авторів / Information about the Authors}

Бісмак Олена Василівна: кандидат наук з фізичного виховання і спорту, доцент: Національний університет фізичного виховання іспорту України: вул. Фізкультури 1, м. Київ, 03150, Україна.

Бисмак Елена Васильевна: кандидат наук по физическому воспитанию и спорту, доцент: Национальный университет физического воспитания и спорта Украины: ул. Физкультуры 1, г. Киев, 03150, Украина.

Olena Bismak: PhD in Physical Education and Sport, Associate Professor: National University of Ukraine on Physical Education and Sport: Fizkul'tury str. 1, Kyiv, 03150, Ukraine.

ORCID.ORG/0000-0002-6495-6170

E-mail: ebismak@gmail.com 


\title{
Прогнозирование перспективности в занятиях танцевальными и гимнастическими видами спорта на основе метода оценки структуры соматотипа индивида
}

\author{
Валерий Друзь \\ Ярослава Волкова \\ Алексей Гуляев
}

\author{
Харьковская государственная академия физической \\ культуры, Харьков, Украина
}

\begin{abstract}
Цель: определить взаимосвязь между двигательными, трофическими и психическими качествами спортсмена в соответствии с конституцией его соматотипа для установления на раннем этапе морфофункционального развития объективных, филогенетически обусловленных признаков двигательной одаренности к занятиям спортивными танцами. Материал и методы: работа выполнялась на базе спортивного клуба "Идеал". В исследовании принимали участие танцоры в количестве 20 спортсменов, занимающиеся спортивными танцами на этапе начальной подготовки. В решении поставленных задач использовались следующие методы: анализ и обобщение научно-методической литературы; обобщение опыта практической работы тренерского контингента, работающего с детьми в группах спортивных танцев; модифицированный метод клинической антропометрии М. Я. Брейтмана; естественный педагогический эксперимент, методы математической статистики и математического моделирования.

Результаты: установлена значимость конкурентных взаимообусловленных отношений конституциональной структуры соматотипа в распределении универсальной ткани - массы тела. Выделены группы самых маленьких частей тела, средние размеры и самые длинные части тела, получены результаты о частоте встречающихся расположений каждого показателя. Составлен универсальный код Собирательного соматотипа.

Выводы: использование модифицированного метода М. Я. Брейтмана позволяет не только определить унифицированный код соматотипа, но и выявить закономерности двигательных и трофических качеств, наиболее ярко выраженных для определенных соматотипов.
\end{abstract}

Ключевые слова: соматотип, структура тела, код, спортивные танцы, естественный эксперимент.

\section{Введение}

Всякое сравнение требует сопоставления количественного выражения одной величины с другой. При этом выясняется вопрос, на сколько либо во сколько одна сравниваемая величина отличается относительно другой. Эта проблема носит абсолютный характер и встречается в любой сфере деятельности. Широкое использование цифровой техники приводит к необходимости разработки методов цифрового выражения информации о качественной характеристике сравниваемых объектов. Исключительным свойством цифрового выражения информации является тот факт, что вне зависимости от качественного ее характера присвоенное число и порядок его следования позволяют в компактной форме накапливать, передавать и в последующем анализировать ее. При возникающей необходимости можно усложнять и расширять необходимую информацию введением включения ее цифрового представления в уже имеющееся кодовое описание.

В области спорта эта проблема имеет исключительный интерес, что определило направленность проводимых исследований.

Цель исследования: определить взаимосвязь между двигательными, трофическими и психическими качествами спортсмена в соответствии с конституцией его соматотипа для установления на раннем этапе морфофункционального развития объективных, филогенетически обусловленных признаков двигательной одаренности к занятиям спортивными танцами.
Задачи исследований: 1) формализовать конституциональные морфофункциональные особенности строения соматотипа в цифровом коде представления филогенетической обусловленности его структуры как информацию о внутренней среде организма; 2) разработать методы и тесты для определения физического и функционального развития спортсменов, максимально соответствующих для занятий спортивными танцами; 3) выявить соответствия между двигательными и трофическими качествами спортсмена в соответствии со структурой соматотипа.

Связь исследований с научными программами, планами, темами. Данная работа выполнялась в соответствии с тематикой Сводного плана научноисследовательских работ в сфере физической культуры и спорта на 2011-2015 гг. по теме 2.6 "Теоретикометодические основы совершенствования тренировочного процесса и соревновательной деятельности в структуре многолетней подготовки спортсменов" (номер государственной регистрации 0111U001168) и инициативной темы кафедры танцевальных видов спорта, фитнеса и гимнастики ХГАФК "Теоретико-методологические основы развития системообразующих компонентов физической культуры (спорт, физическая рекреация, фитнес)" на 2018-2021 гг.

\section{Материал и методы исследования}

Работа выполнялась на базе спортивного клуба "Идеал". В исследовании принимали участие танцоры в количестве 20 спортсменов, занимающиеся спортивными 


\section{SLOBOZANS'KIJ NAUKOVO-SPORTIVNIJ VISNIK}

танцами на этапе начальной подготовки. В решении поставленных задач использовались следующие методы: анализ и обобщение научно-методической литературы; обобщение опыта практической работы тренерского контингента, работающего с детьми в группах спортивных танцев; модифицированный метод клинической антропометрии М. Я. Брейтмана; естественный педагогический эксперимент, методы математической статистики и математического моделирования.

\section{Результаты исследования}

Задача сравнения геометрической структуры строения тела и морфофункциональных особенностей протекаемых процессов рассматривается на протяжении тысячелетий. В период нового времени успешными шагами в решении этой задачи явились исследования Галилея, 1634; Жефруа-Сент-Илера, 1836; К. Дареста, 1865; Бодримон и Мартин Сент-Анже, 1851; А. Герлаха, 1882; Г. Коха, 1884; Кетле, 1870; Гальтон, 1889; М. Я. Брейтмана, 1924. Это крайне незначительное число исследований, которые внесли исключительно значимый вклад в рассматриваемую проблему. Среди работ, обобщающих достижения своих современников и предшественников, можно выделить таких авторов, как Галилей, ЖафруаСент-Илер, М. Я. Брейтман.

Галилей ввел метод физического подобия и размерности, что легло в основу теории аллометрического развития и дискретности процесса формообразования в самоорганизующихся системах. Жофруа-Сент-Илер, обобщая работы своих современников, обратил внимание на необходимость в процессах развития самоорганизующихся систем разделять рост массы и её формацию как два независимых, но взаимообусловленных явления в формировании целостного организма, которое представляет индивидуальные особенности строения соматотипов.

В основе оценки физического развития принято использовать характеристики, которые отражают "структурно-функциональные" свойства организма. Соотношение морфологических и функциональных аспектов биологической природы человека является центральным вопросом антропометрической конституции, отражающей закон единства формы и содержания.

Конституциональное разнообразие соматотипов в популяции отражает проявления меры её реакции на влияние окружающей среды. В свою очередь, концепция "предрасположенности" отражает причины возникновения крайних вариантов отклонения морфофункциональных организаций от нормальных характеристик наблюдаемых популяций человека. Возникающие в них отклонения представляют отражение онтогенеза конституциональных заболеваний, что позволяет использовать особенности конституциональных отклонений в структуре строения соматотипа как их донозологическую диагностику.

Одной из главных задач спортивной антропологии выступает изучение действия разнообразных средств физической активности на телосложение, что обеспечивает достижение успеха в различных видах спортивной специализации. Не менее важной задачей является организация мониторинга развития детей и подростков в различных условиях окружающей среды и установления экстремальных границ этих условий для каждой катего- рии обследуемого контингента. Это, в свою очередь, требует разработки единых стандартных тестов для оценки уровня физической подготовленности и физического развития.

В медицине, которая является главной отраслью практической биологии человека, по мере искоренения инфекционных заболеваний всё в большей мере уделяется внимание конституциональным соматическим болезням. Бенке в 1881 году одним из первых при исследовании конституции соматотипа сформулировал основную цель этого направления, заключающуюся в том, что разнообразие конституции соматотипа отражает специфику сопротивляемости организма определенным болезням, которая проявляется, когда индивид находится в неблагоприятных для него условиях.

В 1924 году М. Я. Брейтман дает глубокое обоснование этому явлению. Его обоснование было основано на положении, что тело является внешним отражением обменных процессов и его биокинематические звенья являются показателями донозологической диагностики нарушений эндокринных взаимоотношений во внутренней среде организма. Эти положения были обоснованы большим количеством наблюдений как врача-эндокринолога, исследовавшего патологию эндокринных нарушений.

Разработанный им метод клинической антропометрии состоял в том, что при сравнении сопоставлялись не абсолютные значения измеряемых частей тела, а их отношения к длине тела индивида. Это позволило при любом росте выделить качественную структуру конституционального строения соматотипа. При этом необходимо знать рост тела обследуемого, возраст и массу тела. Систематизация принятых для измерения частей тела состояла из девяти размеров вертикальных и шести горизонтальных показателей, к которым относятся следующие обозначения: I) верхнее лицо, II) нижнее лицо, III) шея, IV) медиальное вертикальное расстояние между акромиальной и сосковой линией, V) такое же расстояние между сосковой линией и пупком, VI) такое же расстояние между пупком и линией, проходящей через середину паховых складок, VII) длина бедра, VIII) длина голени, (X) высота стопы. Горизонтальные размеры: X) половинное межакромиальное расстояние, $\mathrm{XI}$ ) половинное межсосковое расстояние, XII) длина стопы от пятки до большого пальца. Части руки: XIII) длина плеча, XIV) длина кисти. Формирование структуры строения соматотипов на основе их пропорций осуществлялась на материале обследуемых как нормальных, так и патологических типов. Структура каждого типа представляется в виде вертикального столбика, состоящего из участков, представляющих процентное отношение длины части тела к длине (росту) всего тела. Горизонтальные размеры тела также оценивались относительно к длине всего вертикального роста тела.

Занимаясь аналогичной проблемой анализа типов телосложения, Шелдон в 1940 году пришел к заключению, что концепция типов телосложения выполнила свою положительную роль в изучении структуры телосложения и отошла на задний план и уступила место представлению о непрерывном распределении. Развитие шло от представления о дихотомии отношений до концепции изменчивости по различным пространственным направлениям.

Непрерывность перехода от одного соматотипа к другому закладывается изначально при построении семантического пространства его представления. Основ-
Друзь, В., Волкова, Я., Гуляев, А. (2019), "Прогнозирование перспективности в занятиях танцевальными и гимнастическими видами спорта на основе метода оценки структуры соматотипа индивида", Слобожанський науково-спортивнии вісник, № 6(74), С. 43-50, doi: 10.15391/snsv.2019-6.007

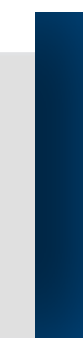

Druz, V., Volkova, Y. \& Huliaiev, O. (2019), "Prediction of prospects in dance and gymnastic sports based on the method of assessing the structure of an individual somatotype", Slobozans'kij naukovo-sportivnij visnik, No. 6(74), pp. 43-50, doi: 10.15391/snsv.2019-6.007 
СЛОБОЖАНСЬКИЙ НАУКОВО-СПОРТИВНИЙ ВІСНИК

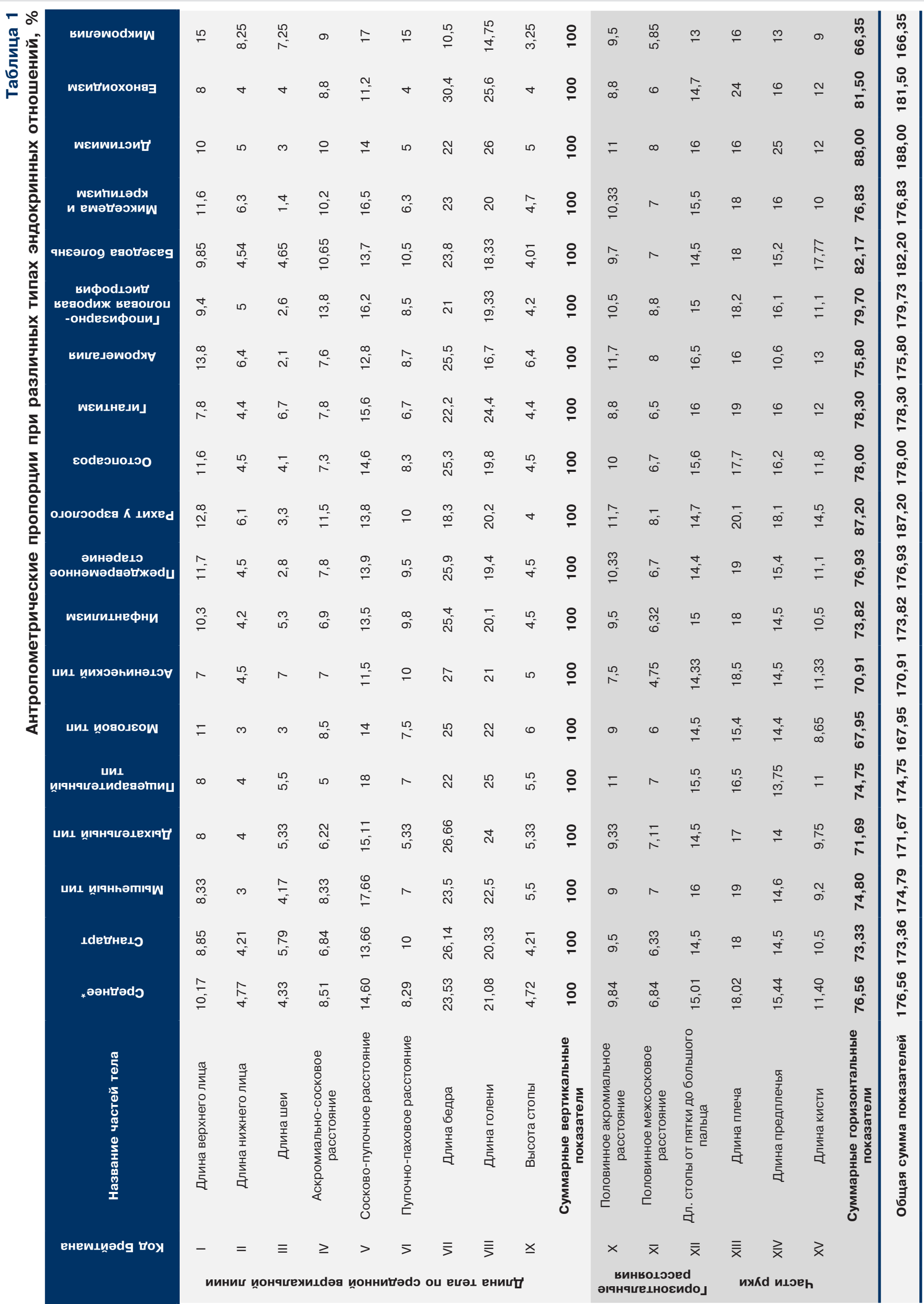




\section{SLOBOZANS'KIJ NAUKOVO-SPORTIVNIJ VISNIK}

ная сложность при этом заключается в измерении изменчивости признаков по разным направлениям осей пространства и установления меры сложности между сравниваемыми соматотипами. Решение этой задачи позволяет установить схожесть содержания различных соматотипов и возможный их переход из одного в другой. Именно эта задача была решена М. Я. Брейтманом за 16 лет до Шелдона.

В проводимых исследованиях были объединены эти два фактически дополняющие друг друга научных подхода. В основе разработки метода оценки индивидуальных особенностей структуры строения соматотипов и мерь их сравнения были использованы диаграммы 18 установленных М. Я. Брейтманом соматотипов, в число которых входят как нормальные, так и патологические типы. В их характеристике используется 15 параметров, имеющих свои размеры в пропорциях ко всему телу. Этим определяется их закрепленная последовательность порядка в шкале наименований частей тела. Структура такого представления дана на табл. 1

Представленная структура наименований частей тела отражает результат формации массы тела во внешнем отображении строения соматотипа как результат внутриконкурентного её перераспределения при протекающей дифференциации специализированных функций заложенного органогенеза и действия внешнего управляющего фактора образовательной внешней среды. Частным случаем внешнего управляющего фактора может являться целенаправленная двигательная деятельность тренировочного процесса. В зависимости от периода возрастного развития эффект и его качественное содержание могут иметь различные последствия. Такое влияние может иметь свое воздействие с момента первого клеточного деления.

Для понимания природы этого воздействия и возможности управления им возникает необходимость более детального его рассмотрения. С этой целью была поставлена задача - установить значимость конкурентных взаимообусловленных отношений конституциональной структуры соматотипа в распределении универсальной ткани - массы тела. Так как тело любого индивида входит в совокупность типов телосложения, установленных

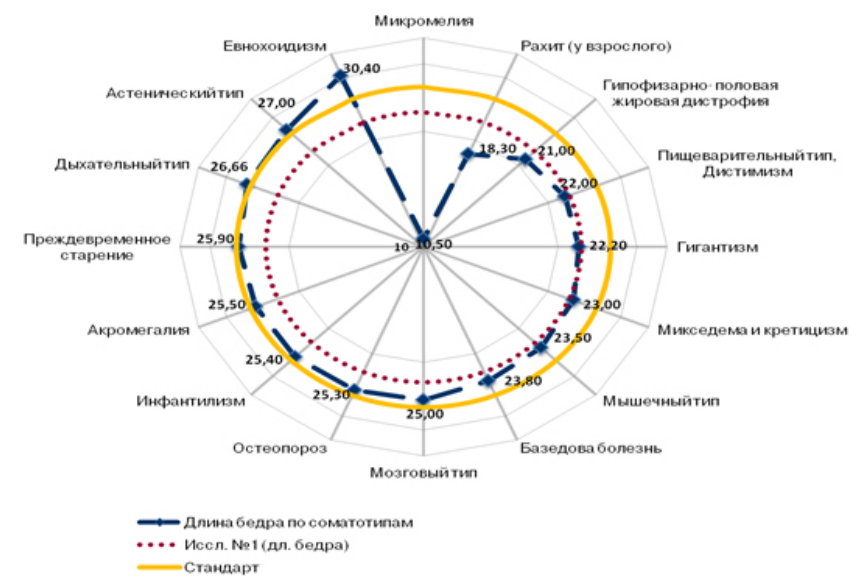

Рис. 1. Отношение показателя "длина бедра" Исследуемого № 1 к аналогичным показателям восемнадцати вариантов соматотипов из табл. 1

М. Я. Брейтманом, то рассматривая его как некий вариант этой совокупности, необходимо провести сличимость каждого элемента тела исследуемого с аналогичными элементами брейтмановской совокупности типов телосложения, выстроив их в последовательном возрастании от минимального своего значения по массе образования до максимально наблюдаемой, включая весь обследуемый контингент.

При проведении этих исследований всякий раз элемент тела обследуемого выступает началом отсчета, а этот элемент каждого соматотипа из таблицы М. Я. Брейтмана и всех предыдущих обследованных сопоставляется с ним. Как пример выполнения данной процедуры, рассмотрим сопоставление "длины бедра" Исследуемого № 1, значений этого показателя к восемнадцати соматотипам из таблицы 1. Результаты проведенной процедуры представлены на рис. 1.

Описанное выше построение сопоставляемых компонентов структуры тела выполнены по всем соматотипам, что позволило построить унифицированные цифровые коды каждого соматотипа. Алгоритм построения цифрового кода показан на примере соматотипа "Стандарт", который был определен М. Я. Брейтманом как наиболее

Таблица 2

Алгоритм построения цифрового кода на примере соматотипа "Стандарт"

\begin{tabular}{|c|c|c|c|c|}
\hline & $\begin{array}{l}\text { № } \\
\Pi / \Pi\end{array}$ & $\begin{array}{c}\text { Наименования частей тела в общей } \\
\text { структуре соматотипа }\end{array}$ & $\begin{array}{c}\text { Структура соматотипа } \\
\text { "Стандарт", в \% от длины } \\
\text { тела }\end{array}$ & $\begin{array}{c}\text { Структура универсального } \\
\text { цифрового кода }\end{array}$ \\
\hline \multirow{9}{*}{ 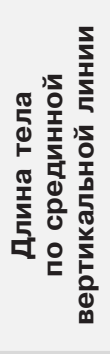 } & 1 & Длина верхнего лица & 8,85 & 6 \\
\hline & II & Длина нижнего лица & 4,21 & 1 \\
\hline & III & Длина шеи & 5,79 & 3 \\
\hline & IV & Аскромиально-сосковое расстояние & 6,84 & 5 \\
\hline & V & Сосково-пупочное расстояние & 13,66 & 10 \\
\hline & VI & Пупочно-паховое расстояние & 10 & 8 \\
\hline & VII & Длина бедра & 26,14 & 15 \\
\hline & VIII & Длина голени & 20,33 & 14 \\
\hline & IX & Высота стопы & 4,21 & 2 \\
\hline \multirow{6}{*}{ 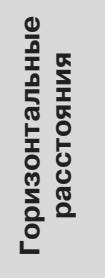 } & $X$ & Половинное акромальное расстояние & 9,5 & 7 \\
\hline & $\mathrm{XI}$ & Половинное межсосковое расстояние & 6,33 & 4 \\
\hline & XII & Длина стопы от пятки до большого пальца & 14,5 & 11 \\
\hline & XIII & Длина плеча & 18 & 13 \\
\hline & XIV & Длина предплечья & 14,5 & 12 \\
\hline & $\mathrm{XV}$ & Длина кисти & 10,5 & 9 \\
\hline
\end{tabular}




\section{СЛОБОЖАНСЬКИЙ НАУКОВО-СПОРТИВНИЙ ВІСНИК}

гармоничный и подтвержден геометрическими построениями в результате проведенных через указанные точки измерения прямых линий и объединение их в единую структуру, отражающую схему строения тела (табл. 2).

По полной аналогии была составлена сводная таблица унифицированных кодов всех соматотипов М. Я. Брейтмана и лиц участвовавших в исследовании (табл. 3).

Исходя из полученных результатов, можно отметить группы самых маленьких частей тела, средние размеры и самые длинные части тела. Таким образом, количество унифицированных кодов соматотипов, которые соответствуют обледуемому контингенту, могут находиться только в пределах соматотипов, определенных М. Я. Брейтманом, отражая меру своей близости к ним.

В ходе анализа исследований были получены результаты о частоте встречающихся расположений каждого показателя, что получило свое отражение в таблице 4.

Также, исходя из полученных результатов, можно увидеть четко выраженные группы самых маленьких частей тела, средние размеры и самые длинные части тела. Таким образом, количество кодов соматотипов, которые соответствуют норме оказывается ограниченным.

Из таблицы 4 видно, что наименьшими частями тела являются показатели под номерами 2, 3 и 9 (2 - это Длина нижнего лица, 3 - Длина шеи, 9 - Высота стопы). Приведенные цифры частоты попаданий показателей на конкретные позиции унифицированного кода соматотипа были рассчитаны по данным таблицы 3.

Если рассмотреть эту же таблицу частоты попаданий номера показателя на позицию кода в процентном соотношении к количеству выпавших показателей, то получим таблицу 5.

Исходя из полученных результатов по таблице 5, можно составить универсальный код Собирательного соматотипа, который состоит из самых часто встречающихся показателей в порядке возрастания (табл. 6).

\section{Выводы / Дискуссия}

Использование модифицированного метода М. Я. Брейтмана позволяет не только определить унифицированный код соматотипа, но и выявить закономерно-

Таблица 3

Сводная таблица кодов соматотипов

\begin{tabular}{|c|c|c|c|c|c|c|c|c|c|c|c|c|c|c|c|c|}
\hline \multirow[t]{2}{*}{ № } & \multirow{2}{*}{$\begin{array}{c}\text { Шкала названий } \\
\text { соматотипов }\end{array}$} & \multicolumn{15}{|c|}{$\begin{array}{c}\text { Шкала порядка } 15 \text { элементов соматотипов, выстроенных в последовательности } \\
\text { от минимального значения величины элемента тела до максимального в } \\
\text { перераспределении массы тела на свою формацию в построении соматотипа }\end{array}$} \\
\hline & & I & II & III & IV & $\mathbf{v}$ & VI & VII & VIII & IX & $\mathbf{x}$ & $\mathbf{X I}$ & XII & XIII & XIV & $\mathbf{X V}$ \\
\hline 1. & Дыхательный тип & 2 & 3 & 6 & 9 & 4 & 11 & 1 & 10 & 15 & 14 & 12 & 5 & 13 & 8 & 7 \\
\hline 2. & Евнохоидизм & 2 & 3 & 6 & 9 & 11 & 1 & 4 & 10 & 5 & 15 & 12 & 14 & 13 & 8 & 7 \\
\hline 3. & Мышечный тип & 2 & 3 & 9 & 6 & 11 & 1 & 4 & 10 & 15 & 14 & 12 & 5 & 13 & 8 & 7 \\
\hline 4. & Мозговой тип & 2 & 3 & 9 & 11 & 6 & 4 & 15 & 10 & 1 & 5 & 14 & 12 & 13 & 8 & 7 \\
\hline 5. & Исследуемый 1 & 2 & 3 & 9 & 11 & 1 & 6 & 10 & 15 & 4 & 13 & 14 & 12 & 5 & 7 & 8 \\
\hline 6. & Исследуемый 2 & 2 & 3 & 9 & 10 & 11 & 4 & 6 & 1 & 15 & 13 & 14 & 5 & 12 & 7 & 8 \\
\hline 7. & Исследуемый 3 & 2 & 3 & 10 & 9 & 11 & 4 & 6 & 1 & 15 & 14 & 5 & 12 & 13 & 7 & 8 \\
\hline 8. & Исследуемый 4 & 2 & 3 & 10 & 9 & 11 & 6 & 1 & 12 & 15 & 5 & 4 & 14 & 13 & 7 & 8 \\
\hline 9. & Исследуемый 5 & 2 & 3 & 10 & 11 & 9 & 4 & 1 & 6 & 15 & 12 & 14 & 5 & 13 & 8 & 7 \\
\hline 10. & Исследуемый 6 & 2 & 3 & 11 & 9 & 4 & 15 & 10 & 1 & 6 & 12 & 14 & 5 & 8 & 13 & 7 \\
\hline 11. & Пищеварительный тип & 2 & 4 & 3 & 9 & 6 & 11 & 1 & 10 & 15 & 14 & 12 & 13 & 5 & 7 & 8 \\
\hline 12. & Исследуемый 7 & 2 & 6 & 10 & 3 & 9 & 11 & 4 & 1 & 15 & 14 & 12 & 13 & 5 & 7 & 8 \\
\hline 13. & Исследуемый 8 & 2 & 9 & 3 & 10 & 11 & 6 & 1 & 15 & 4 & 12 & 5 & 13 & 14 & 8 & 7 \\
\hline 14. & Стандарт & 2 & 9 & 3 & 11 & 4 & 1 & 10 & 6 & 15 & 5 & 12 & 14 & 13 & 8 & 7 \\
\hline 15. & Инфантилизм & 2 & 9 & 3 & 11 & 4 & 10 & 6 & 1 & 15 & 5 & 14 & 12 & 13 & 8 & 7 \\
\hline 16. & Гигантизм & 2 & 9 & 11 & 3 & 6 & 1 & 4 & 10 & 15 & 5 & 12 & 14 & 13 & 7 & 8 \\
\hline 17. & Астенический тип & 2 & 11 & 9 & 1 & 3 & 4 & 10 & 6 & 15 & 5 & 12 & 14 & 13 & 8 & 7 \\
\hline 18. & Дистимизм & 3 & 2 & 6 & 9 & 11 & 1 & 4 & 10 & 15 & 5 & 12 & 13 & 7 & 14 & 8 \\
\hline 19. & Исследуемый 9 & 3 & 2 & 6 & 9 & 10 & 11 & 4 & 1 & 15 & 12 & 5 & 14 & 13 & 8 & 7 \\
\hline 20. & Акромегалия & 3 & 2 & 9 & 4 & 11 & 6 & 14 & 10 & 5 & 15 & 1 & 13 & 12 & 8 & 7 \\
\hline 21. & Преждеврем. старение & 3 & 2 & 9 & 11 & 4 & 6 & 10 & 15 & 1 & 5 & 12 & 14 & 13 & 8 & 7 \\
\hline 22. & Остеопороз & 3 & 2 & 9 & 11 & 4 & 6 & 10 & 1 & 15 & 5 & 12 & 14 & 13 & 8 & 7 \\
\hline 23. & Исследуемый 10 & 3 & 2 & 10 & 6 & 9 & 11 & 4 & 1 & 12 & 15 & 13 & 14 & 5 & 7 & 8 \\
\hline 24. & Исследуемый 11 & 3 & 2 & 10 & 9 & 11 & 4 & 6 & 15 & 1 & 14 & 13 & 5 & 12 & 7 & 8 \\
\hline 25. & Исследуемый 12 & 3 & 2 & 11 & 9 & 4 & 6 & 10 & 15 & 1 & 12 & 5 & 13 & 14 & 7 & 8 \\
\hline 26. & $\begin{array}{c}\text { Гипофизарно-половая } \\
\text { жировая дистрофия }\end{array}$ & 3 & 9 & 2 & 6 & 11 & 1 & 10 & 15 & 4 & 12 & 14 & 5 & 13 & 8 & 7 \\
\hline 27. & Микседема и кретинизм & 3 & 9 & 2 & 6 & 11 & 15 & 4 & 10 & 1 & 12 & 14 & 5 & 13 & 8 & 7 \\
\hline 28. & Рахит (у взрослого) & 3 & 9 & 2 & 11 & 6 & 4 & 10 & 1 & 5 & 15 & 12 & 14 & 7 & 13 & 8 \\
\hline 29. & Среднее & 3 & 9 & 2 & 11 & 6 & 4 & 10 & 1 & 15 & 5 & 12 & 14 & 13 & 8 & 7 \\
\hline 30. & Исследуемый 13 & 3 & 11 & 2 & 9 & 10 & 15 & 6 & 12 & 13 & 1 & 4 & 14 & 5 & 8 & 7 \\
\hline 31. & Базедова болезнь & 9 & 2 & 3 & 11 & 10 & 1 & 6 & 4 & 5 & 12 & 14 & 15 & 13 & 8 & 7 \\
\hline 32. & Микромелия & 9 & 11 & 3 & 2 & 4 & 15 & 10 & 7 & 12 & 14 & 8 & 1 & 6 & 13 & 5 \\
\hline
\end{tabular}
представленных соматотипов. 


\section{SLOBOZANS'KIJ NAUKOVO-SPORTIVNIJ VISNIK}

Таблица 4

Количество попаданий каждого номера показателя на позицию универсального кода соматотипа (позиции пронумерованы в порядке возрастания величин показателей)

\begin{tabular}{|c|c|c|c|c|c|c|c|c|c|c|c|c|c|c|c|c|c|}
\hline \multirow{2}{*}{ 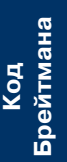 } & \multirow[b]{2}{*}{ Наименование частей тела } & \multicolumn{16}{|c|}{ Шкала порядка (следований частей тела) } \\
\hline & & I & II & III & IV & $\mathbf{v}$ & VI & vil & VIII & IX & $\mathbf{x}$ & $\mathbf{X I}$ & XII & XIIII & XIV & xv & Итого \\
\hline 1 & Длина верхнего лица & 0 & 0 & 0 & 1 & 1 & 7 & 5 & 10 & 5 & 1 & 1 & 1 & 0 & 0 & 0 & 32 \\
\hline II & Длина нижнего лица & 17 & 9 & 5 & 1 & 0 & 0 & 0 & 0 & 0 & 0 & 0 & 0 & 0 & 0 & 0 & 32 \\
\hline III & Длина шеи & 13 & 10 & 6 & 2 & 1 & 0 & 0 & 0 & 0 & 0 & 0 & 0 & 0 & 0 & 0 & 32 \\
\hline IV & Аскромиально-сосковое расстояние & 0 & 1 & 0 & 1 & 8 & 8 & 8 & 1 & 3 & 0 & 2 & 0 & 0 & 0 & 0 & 32 \\
\hline V & Сосково-пупочное расстояние & 0 & 0 & 0 & 0 & 0 & 0 & 0 & 0 & 4 & 10 & 4 & 8 & 5 & 0 & 1 & 32 \\
\hline $\mathrm{VI}$ & Пупочно-паховое расстояние & 0 & 1 & 4 & 4 & 5 & 7 & 6 & 3 & 1 & 0 & 0 & 0 & 1 & 0 & 0 & 32 \\
\hline VII & Длина бедра & 0 & 0 & 0 & 0 & 0 & 0 & 0 & 1 & 0 & 0 & 0 & 0 & 2 & 10 & 19 & 32 \\
\hline VIII & Длина голени & 0 & 0 & 0 & 0 & 0 & 0 & 0 & 0 & 0 & 0 & 1 & 0 & 1 & 18 & 12 & 32 \\
\hline IX & Высота стопы & 2 & 8 & 8 & 11 & 3 & 0 & 0 & 0 & 0 & 0 & 0 & 0 & 0 & 0 & 0 & 32 \\
\hline $\mathrm{x}$ & Половинное акромальное расстояние & 0 & 0 & 6 & 2 & 3 & 1 & 11 & 9 & 0 & 0 & 0 & 0 & 0 & 0 & 0 & 32 \\
\hline $\mathrm{XI}$ & Половинное межсосковое расстояние & 0 & 3 & 3 & 10 & 11 & 5 & 0 & 0 & 0 & 0 & 0 & 0 & 0 & 0 & 0 & 32 \\
\hline XII & Длина стопы от пятки до большого пальца & 0 & 0 & 0 & 0 & 0 & 0 & 0 & 2 & 2 & 8 & 13 & 4 & 3 & 0 & 0 & 32 \\
\hline XIII & Длина плеча & 0 & 0 & 0 & 0 & 0 & 0 & 0 & 0 & 1 & 2 & 2 & 6 & 18 & 3 & 0 & 32 \\
\hline XIV & Длина предплечья & 0 & 0 & 0 & 0 & 0 & 0 & 1 & 0 & 0 & 7 & 9 & 12 & 2 & 1 & 0 & 32 \\
\hline$x v$ & Длина кисти & 0 & 0 & 0 & 0 & 0 & 4 & 1 & 6 & 16 & 4 & 0 & 1 & 0 & 0 & 0 & 32 \\
\hline & Итого & 32 & 32 & 32 & 32 & 32 & 32 & 32 & 32 & 32 & 32 & 32 & 32 & 32 & 32 & 32 & 480 \\
\hline
\end{tabular}

Примечание. Затемнением выделены значения с показателями более 1.

Таблица 5

Количество попаданий каждого номера показателя на позицию универсального кода соматотипа (позиции пронумерованы в порядке возрастания величин показателей) выраженное, \%

\begin{tabular}{|c|c|c|c|c|c|c|c|c|c|c|c|c|c|c|c|c|c|}
\hline \multirow{2}{*}{ 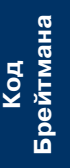 } & \multirow[b]{2}{*}{ Наименование частей тела } & \multicolumn{15}{|c|}{ Шкала порядка (следований частей тела) } & \multirow[b]{2}{*}{ Итого } \\
\hline & & $\mathbf{I}$ & II & III & IV & v & VI & VII & VIII & $\mathbf{I X}$ & $\mathbf{x}$ & $\mathbf{X I}$ & XII & XIII & XIV & $\mathbf{x v}$ & \\
\hline 1 & Длина верхнего лица & 0 & 0 & 0 & 3 & 3 & 22 & 16 & 31 & 16 & 3 & 3 & 3 & 0 & 0 & 0 & 100 \\
\hline ॥ & Длина нижнего лица & 53 & 28 & 16 & 3 & 0 & 0 & 0 & 0 & 0 & 0 & 0 & 0 & 0 & 0 & 0 & 100 \\
\hline IIII & Длина шеи & 41 & 31 & 19 & 6 & 3 & 0 & 0 & 0 & 0 & 0 & 0 & 0 & 0 & 0 & 0 & 100 \\
\hline IV & Аскромиально-сосковое расстояние & 0 & 3 & 0 & 3 & 25 & 25 & 25 & 3 & 9 & 0 & 6 & 0 & 0 & 0 & 0 & 100 \\
\hline $\mathrm{v}$ & Сосково-пупочное расстояние & 0 & 0 & 0 & 0 & 0 & 0 & 0 & 0 & 13 & 31 & 13 & 25 & 16 & 0 & 3 & 100 \\
\hline $\mathrm{VI}$ & Пупочно-паховое расстояние & 0 & 3 & 13 & 13 & 16 & 22 & 19 & 9 & 3 & 0 & 0 & 0 & 3 & 0 & 0 & 100 \\
\hline VII & Длина бедра & 0 & 0 & 0 & 0 & 0 & 0 & 0 & 3 & 0 & 0 & 0 & 0 & 6 & 31 & 59 & 100 \\
\hline VIII & Длина голени & 0 & 0 & 0 & 0 & 0 & 0 & 0 & 0 & 0 & 0 & 3 & 0 & 3 & 56 & 38 & 100 \\
\hline IX & Высота стопы & 6 & 25 & 25 & 34 & 9 & 0 & 0 & 0 & 0 & 0 & 0 & 0 & 0 & 0 & 0 & 100 \\
\hline $\mathrm{x}$ & Половинное акромальное расстояние & 0 & 0 & 19 & 6 & 9 & 3 & 34 & 28 & 0 & 0 & 0 & 0 & 0 & 0 & 0 & 100 \\
\hline $\mathrm{XI}$ & Половинное межсосковое расстояние & 0 & 9 & 9 & 31 & 34 & 16 & 0 & 0 & 0 & 0 & 0 & 0 & 0 & 0 & 0 & 100 \\
\hline XII & $\begin{array}{l}\text { Длина стопы от пятки до большого } \\
\text { пальща }\end{array}$ & 0 & 0 & 0 & 0 & 0 & 0 & 0 & 6 & 6 & 25 & 41 & 13 & 9 & 0 & 0 & 100 \\
\hline XIII & Длина плеча & 0 & 0 & 0 & 0 & 0 & 0 & 0 & 0 & 3 & 6 & 6 & 19 & 56 & 9 & 0 & 100 \\
\hline XIV & Длина предплечья & 0 & 0 & 0 & 0 & 0 & 0 & 3 & 0 & 0 & 22 & 28 & 38 & 6 & 3 & 0 & 100 \\
\hline $\mathrm{XV}$ & Длина кисти & 0 & 0 & 0 & 0 & 0 & 13 & 3 & 19 & 50 & 13 & 0 & 3 & 0 & 0 & 0 & 100 \\
\hline & Итого & 100 & 100 & 100 & 100 & 100 & 100 & 100 & 100 & 100 & 100 & 100 & 100 & 100 & 100 & 100 & \\
\hline
\end{tabular}

Примечание. Затемнением выделены максимальные значения, полученные по столбцам.

сти двигательных и трофических качеств, наиболее ярко выраженных для определенных соматотипов.

Проведение дальнейшие исследований с использованием стандартизированных тестов дает возможность установить непосредственную связь между заложенными филогенетически предопределенным соотношением уровня развития физических качеств спортсмена и его унифицированным кодом соматотипа.
Соответствие между унифицированным кодом соматотипа и его физическими качествами позволяет точно подбирать членов команды в формировании более устойчивых и результативных пар в спортивных танцах, и выбор наиболее оптимальных видов организации тренировок для развития необходимого соотношения двигательных качеств спортсмена в достижении высоких спортивных результатов. 


\section{СЛОБОЖАНСЬКИЙ НАУКОВО-СПОРТИВНИЙ ВІСНИК}

Таблица 6

Универсальный код Собирательного соматотипа

\begin{tabular}{|c|c|c|c|c|c|c|c|c|c|c|c|c|c|c|c|}
\hline Универсальный Код & 2 & 3 & 9 & 11 & 4 & 6 & 10 & 1 & 15 & 12 & 14 & 5 & 13 & 8 & 7 \\
\hline Код Брейтмана & II & III & IX & $\mathbf{X} \mathbf{I}$ & IV & VI & $\mathbf{x}$ & $\mathbf{I}$ & $\mathbf{X V}$ & XII & XIV & $\mathbf{v}$ & XIII & VIII & VII \\
\hline 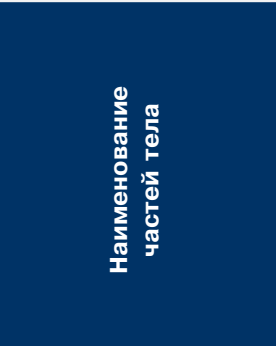 & 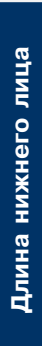 & 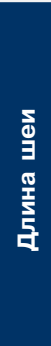 & 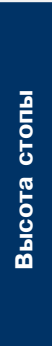 & 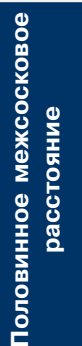 & 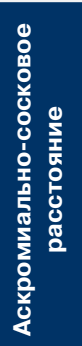 & 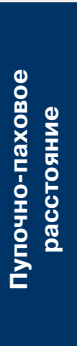 & 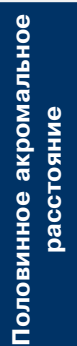 & 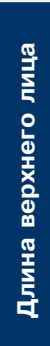 & 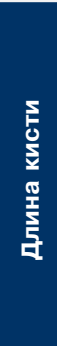 & 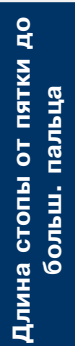 & 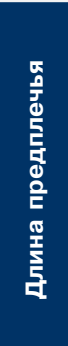 & 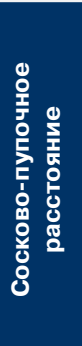 & $\begin{array}{l}\frac{\text { W }}{\sigma} \\
\frac{5}{5} \\
\frac{5}{5} \\
\frac{\pi}{5} \\
5 \\
5\end{array}$ & 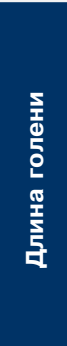 & 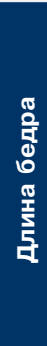 \\
\hline
\end{tabular}

При проведении дальнейших исследований в этом направлении отбора спортсменов на начальном его этапе данный метод будет полностью автоматизирован. По-

строение модели соматотипа на основе естественного педагогического эксперимента, обеспечивающего отбор спортсменов, которые достигли наивысших результатов.

Конфликт интересов. Авторы заявляют, что нет конфликта интересов, который может восприниматься как такой, что может нанести вред беспристрастности статьи. Источники финансирования. Эта статья не получила финансовой поддержки от государственной, общественной или коммерческой организации.

\section{Список ссылок}

1. Артемьева, Г.П., Пугач, Я.И., Друзь, В.А. (2014), Проблема адаптации в структуре научных исследований системы олимпийского образования: монография, ХГАФК, Харьков.

2. Брейтман, М.Я. (1949), Клиническая семиотика и дифференциальная диагностика эндокринных заболеваний, Медгиз, Ленинград.

3.Брейтман, М.Я. (1926), Таблицы для клинической антропометрии, Изд-во "П.П. Сойкин", Ленинград.

4. Друзь, В.А., Артемьева, Г.П., Бурень, Н.В. и др. (2013), Теоретические и прикладные основы построения мониторинга физического развития, физической подготовленности и физического состояния: учебное пособие, ХГАФК, Харьков.

5. Ефимов, Н.В. (1971), Высшая геометрия, Наука, Москва.

6. Платонов, В.Н. (2004), Система подготовки спортсменов в олимпийском спорте. Общая теория и ее практическое применение: учеб. для студентов вузов физ. восп. и спорта, Олимпийская литература, Киев.

7. Савелов, А.А. (1960), Плоские кривые. Систематика, свойства, применения, Гос. Издат-во физ.-мат. Лит., Москва.

8. Самсонкин, В.Н., Друзь, В.А., Федорович, Е.С. (2010), Моделирование в самоорганизующихся системах, Донецк.

9. Седов, Л.И. (1981), Методы подобия и размерности в механике, Наука, Москва.

10. Стахов, А.П. (2006), "Золотое сечение, священная геометрия и математика гармонии", Метафизика. Век XXI, Бином, Москва, C. $174-215$.

11. Фильченко, Ю.А. (1925), Гальтон и Мендель, Москва.

12. Kin-itsu Hirata \& Kanae Kaku (1968), The evaluating method of physique and physical fitness and its practical application, Hirata Institute of Health.

13. Sheldon, W.H. (1954), Atlas of Man, Harper and Brothers, New York.

14. Galton, Sir F. (1889), Natural Inheritance, London.

Стаття надійшла до редакції: 08.11.2019 р.

Опубліковано: 30.12.2019 р.

Анотація. Валерій Друзь, Ярослава Волкова, Олексій Гуляєв. Прогнозування перспективності у заняттях танцювальними і гімнастичними видами спорту на основі методу оцінки структури соматотипа індивіда. Мета: визначити взаємозв'язок між руховими, трофічними і психічними якостями спортсмена відповідно до конституції його соматотипа для встановлення на ранньому етапі морфофункціонального розвитку об'єктивних, філогенетично обумовлених ознак рухової обдарованості до занять спортивними танцями. Матеріал і методи: робота виконувалася на базі спортивного клубу "Ідеал". У дослідженні брали участь танцюристи у кількості 20 спортсменів, які займаються спортивними танцями на етапі початкової підготовки. У вирішенні поставлених завдань використовувалися такі методи: аналіз і узагальнення науково-методичної літератури; узагальнення досвіду практичної роботи тренерського контингенту, що працює з дітьми в групах спортивних танців; модифікований метод клінічної антропометрії М. Я. Брейтмана; природний педагогічний експеримент, методи математичної статистики і математичного моделювання. Результати: встановлено значимість конкурентних взаємообумовлених відносин конституціональної структури соматотипа в розподілі універсальної тканини - маси тіла. Виокремлено групи найменших частин тіла, середні розміри і найдовші частини тіла, отримано результати про частоту розташувань, що зустрічаються, кожного показника. Складено універсальний код Збірного соматотипа. Висновки: використання модифікованого методу М. Я. Брейтмана дозволяє не тільки визначити уніфікований код соматотипа, але і виявити закономірності рухових і трофічних якостей, найбільш яскраво виражених для певних соматотипів.

Ключові слова: соматотип, структура тіла, код, спортивні танці, природний експеримент.

Abstract. Valeriy Druz, Yaroslava Volkova \& Oleksii Huliaiev. Prediction of prospects in dance and gymnastic sports based on the method of assessing the structure of an individual somatotype. Purpose: to determine the relationship between the motor, trophic and mental qualities of an athlete in accordance with the constitution of his somatotype in order to establish at an early stage of the 


\section{SLOBOZANS'KIJ NAUKOVO-SPORTIVNIJ VISNIK}

morphofunctional development of objective, phylogenetically determined signs of motor talent for sports dancing. Material \& Methods: the work was carried out on the basis of the "Ideal" sports club. The study involved dancers in the amount of 20 athletes involved in sports dancing at the initial training stage. In solving the tasks, the following methods were used: analysis and synthesis of scientific and methodological literature; generalization of the practical experience of the coaching contingent working with children in sports dance groups; a modified method of clinical anthropometry M. Ya. Breitman; natural pedagogical experiment, methods of mathematical statistics and mathematical modeling. Results: the significance of competitive interdependent relationships of the constitutional structure of the somatotype in the distribution of universal tissue - body weight was established. The groups of the smallest parts of the body, the average sizes and the longest parts of the body are distinguished, and results are obtained on the frequency of occurring locations of each indicator. Compiled a universal code of the Collective somatotype. Conclusions: the use of the modified method of M. Ya. Breitman allows not only to determine the unified somatotype code, but also to reveal the patterns of motor and trophic qualities most pronounced for certain somatotypes.

Keywords: somatotype, body structure, code, sports dancing, natural experiment.

\section{References}

1. Artemeva, G.P., Pugach, Ya.I. \& Druz, V.A. (2014), Problema adaptatsii v strukture nauchnykh issledovaniy sistemy olimpiyskogo obrazovaniya: monografiya [The problem of adaptation in the structure of scientific research of the Olympic education system], KhSAPC, Kharkov. (in Russ.)

2. Breytman, M.Ya. (1949), Klinicheskaya semiotika i differentsialnaya diagnostika endokrinnykh zabolevaniy [Clinical semiotics and differential diagnosis of endocrine diseases], Medgiz, Leningrad. (in Russ.)

3. Breytman, M.Ya. (1926), Tablitsy dlya klinicheskoy antropometrii [Tables for clinical anthropometry], Publishing House "P.P. Soykin", Leningrad. (in Russ.)

4. Druz, V.A., Artemeva, G.P., Buren, N.V. et al. (2013), Teoreticheskie i prikladnye osnovy postroeniya monitoringa fizicheskogo razvitiya, fizicheskoy podgotovlennosti i fizicheskogo sostoyaniya: uchebnoe posobie [Theoretical and applied foundations for constructing monitoring of physical development, physical fitness and physical condition], KhSAPC, Kharkov. (in Russ.)

5. Yefimov, N.V. (1971), Vysshaya geometriya [Higher Geometry], Nauka, Moscow. (in Russ.)

6. Platonov, V.N. (2004), Sistema podgotovki sportsmenov v olimpiyskom sporte. Obshchaya teoriya i ee prakticheskoe primenenie: ucheb. dlya studentov vuzov fiz. vosp. i sporta [The system of training athletes in Olympic sports. General theory and its practical application], Olimpiyskaya literatura, Kiev. (in Russ.)

7. Savelov, A.A. (1960), Ploskie krivye. Sistematika, svoystva, primeneniya [Flat Curves. Systematics, properties, applications], State Publishing House of Phys.-Math. Lit., Moscow. (in Russ.)

8. Samsonkin, V.N., Druz, V.A. \& Fedorovich, Ye.S. (2010), Modelirovanie v samoorganizuyushchikhsya sistemakh [Modeling in selforganizing systems], Donetsk. (in Russ.)

9. Sedov, L.I. (1981), Metody podobiya i razmernosti v mekhanike [Methods of similarity and dimension in mechanics], Nauka, Moscow. (in Russ.)

10. Stakhov, A.P. (2006), "The Golden Ratio, Sacred Geometry and the Mathematics of Harmony", Metaphysics. Century XXI, Binom, Moscow, pp. 174-215. (in Russ.)

11. Filchenko, Yu.A. (1925), Galton i Mendel [Galton and Mendel], Moscow. (in Russ.)

12. Kin-itsu Hirata \& Kanae Kaku (1968), The evaluating method of physique and physical fitness and its practical application, Hirata Institute of Health.

13. Sheldon, W.H. (1954), Atlas of Man, Harper and Brothers, New York.

14. Galton, Sir F. (1889), Natural Inheritance, London.

Received: 08.11.2019

Published: 30.12 .2019

\section{Відомості про авторів / Information about the Authors}

Друзь Валерій Анатолійович: д. б. н., професор; Харківська державна академія фізичної культури: вул. Клочківська 99, м. Харків, 61058, Україна

Друзь Валерий Анатольевич: д. б. н., профессор; Харьковская государственная академия физической культуры: ул. Клочковская 99, г. Харьков, 61058, Украина.

Valeriy Druz: Doctor of Science (Biology), Professor; Kharkiv State Academy of Physical Culture: Klochkivska 99, Kharkiv, 61058, Ukraine.

ORCID.ORG/0000-0002-4628-6791

E-mail: valeriidruz@gmail.com

Ярослава Волкова: Харківська державна академія фізичної культури: Україна, м. Харків, вул. Клочківська, 99.

Ярослава Волкова: Харьковская государственная академия физической культуры: ул. Клочковская 99, г. Харьков, 61058, Украина.

Yaroslava Volkova: Kharkiv State Academy of Physical Culture: Klochkivska str. 99, Kharkiv, 61058, Ukraine.

ORCID.ORG/0000-0001-9274-2076

E-mail: yguliaeva81@gmail.com

Олексій Гуляєв: Харківська державна академія фізичної культури: Україна, м. Харків, вул. Клочківська, 99.

Алексей Гуляев: Харьковская государственная академия физической культуры: ул. Клочковская 99, г. Харьков, 61058, Украина

Oleksii Huliaiev: Kharkiv State Academy of Physical Culture: Klochkivska str. 99, Kharkiv, 61058, Ukraine.

ORCID.ORG/0000-0002-5010-5965

E-mail: Alex.Gulyaev@gmail.com

Друзь, В., Волкова, Я., Гуляев, А. (2019), "Прогнозирование перспективности в занятиях танцевальными и гимнастическими видами спорта на основе метода оценки структуры соматотипа индивида", Слобожанський науково-спортивний вісник, № 6(74), С. 43-50, doi: 10.15391/snsv.2019-6.007 


\title{
Вплив занять різними видами фітнесу 3 урахуванням оваріально-менструального циклу на психофізичний стан молодих жінок
}

\author{
Олена Шишкіна' \\ Ігор Бейгул ${ }^{1}$ \\ Алла Муллагільдіна²
}

\author{
'Дніпровський державний технічний університет, \\ Кам'янське, Україна \\ ${ }^{2}$ Харківська державна академія фізичної культури, \\ Харків, Україна
}

\begin{abstract}
Мета: визначити вплив занять різними видами фітнесу з урахуванням оваріально-менструального циклу на психофізичний стан молодих жінок.

Матеріал і методи: удослідженні прийняли участь молоді жінки віком 21-25 років ( $n=84)$, які розподілені на дві групи: контрольну $(K Г, n=36)$ та експериментальну $(E \Gamma, n=48)$. Контрольна група займалась базовою аеробікою, пілатесом та стретчингом без урахування фаз оваріально-менструального циклу, експериментальна - різними видами фітнесу відповідно до фаз ОМЦ. Заняття проводились 3 рази на тиждень, дослідження тривало протягом 12 місяців. Визначали функціональні можливості за такими показниками: частота серцевих скорочень у стані спокою, артеріальний тиск, час відновлення після 20 присідань за 30 с; фізичну підготовленість за такими показниками: "човниковий біг 4х9 м", с; "стрибок у довжину з місця", см; "підйом тулуба в сід" за одну хвилину, кількість разів; "нахил вперед з положення сидячи", см. Рівень прояву психологічної сфери за методикою Н. Е. Водоп'янової "Оцінка задоволеності якістю життя". Результати: порівняльний аналіз обох груп показав, що в ЕГ відбулося достовірне $(p<0,05-0,01)$ покращення функціональних можливостей. Найбільший вплив використання засобів різних видів фітнесу справило на показники ЧСС у стані спокою, уд. хвв" : з оцінки "задовільно" до "добре"; час відновлення після 20 присідань за 30 с, с: з оцінки "нижче середнього", до "вище середнього". Показники фізичної підготовленості в ЕГ у порівнянні з КГ також значно покращились $(p<0,05-0,01)$. Встановлено, що найбільші зміни відбулися у показниках тесту силової витривалості м'язів черевного пресу та гнучкості: з оцінки "незадовільно" до "відмінно". Виявлено, що особиста оцінка задоволеності якістю життя ЕГ суттєво $(p<0,05-0,01)$ відрізняється від КГ. У перших поліпшилося відношення до своєї діяльності, самоконтроль, самооцінка, сприйняття здоров'я, підтримка друзів та оптимістичність при одночасному зменшенні напруженості та ступеня прояву негативних емоцій.
\end{abstract}

Висновки: використання оздоровчої методики поєднання різних видів фітнесу сприятливо відбилося на психофізичному стані молодих жінок. Існує можливість застосування розробленої методики у практиці оздоровчих тренувань.

Ключові слова: оздоровчий фітнес, психофізичний стан, оваріально-менструальний цикл, молоді жінки, тренувальні навантаження.

\section{Вступ}

У сучасних умовах в Україні зростає соціальна значимість здоров'я з точки зору суспільства. Здоров'я нації у наш час розглядається як показник цивілізованості держави, що відображає соціально-економічний стан суспільства [3].

У зв'язку з низьким рівнем народжуваності проблема охорони та збереження репродуктивної функції, здоров'я населення України набуває особливого значення. В останні роки фіксується негативна тенденція, яка пов'язана зі збільшенням відхилень у роботі найважливіших систем організму, зниженням його опірності, підвищенням кількості хронічних захворювань у жінок молодого віку [15]. Концепція фізичної культури пропонує з метою збереження здоров'я застосовувати оптимальний рівень фізичної активності [17; 21]. Одним із провідних завдань оздоровчих тренувань $€$ поліпшення психофізичного стану молодих жінок, що багато в чому зумовлює рівень здоров'я подальшого покоління [5; 23]. У зв'язку з цим актуальною проблемою $є$ пошук інноваційних шляхів оптимізації фізкультурно-оздоровчих занять у фізичному вихованні молоді.

Науковці [2; 22; 24] вважають, що фітнес - це система занять фізичною культурою, яка спрямована не лише на підтримання гарної фізичної форми, але й включає інте- лектуальний, емоційний, соціальний та духовний компоненти. Сьогодні саме це поняття дозволяє повною мірою відобразити соціальні (здоровий спосіб життя), біологічні (рухова активність, фізичний стан і фізична підготовленість), психологічні (мотиви, інтереси) та інші характеристики застосування засобів фізичного виховання з оздоровчою метою.

Аналіз науково-методичної літератури свідчить, що при сучасному розвитку фітнес-індустрії жінкам молодого віку надається широкий вибір різних фітнес-програм [12; 13; 18; 25]. У той же час існує незначна кількість робіт, де розглядається планування об'єму, інтенсивності та спрямованості тренувальних навантажень з урахуванням оваріально-менструального циклу в оздоровчих заняттях з фітнесу. Окремі роботи присвячені вивченню впливу оздоровчих занять на фізичну працездатність [4; 9; 19], на фізичний розвиток [7; 10], на фізичну підготовленість [11; 20].

Фізкультурно-оздоровчі заняття, зазвичай, проводяться груповим методом без урахування фізичних, функціональних та біологічних можливостей молодих жінок, що не дозволяє ефективно дозувати фізичне навантаження. Щодо психологічного критерію, слід зазначити, що він практично не застосовується для аналізу впливу фізкультурно-оздоровчих занять на показники здоров'я молоді, хоча рекомендації до цього зустрічаються в дея- 


\section{SLOBOZANS'KIJ NAUKOVO-SPORTIVNIJ VISNIK}

ких дослідженнях; крім того, автори роблять висновки про підвищення психоемоційного стану дівчат, не застосовуючи психологічні тести в своїх дослідженнях.

Для вирішення даних задач виникає потреба в індивідуальному підході до планування навантаження, а також використання засобів не окремого виду фітнесу, а поєднання декількох його видів. При цьому комплексне застосування різних видів фітнесу потребує більш досконалої системи планування, де можливе раціональне поєднання вправ різної спрямованості з урахуванням біоритміки жіночого організму.

Мета дослідження: визначити вплив занять різними видами фітнесузурахуваннямоваріально-менструального циклу на психофізичний стан молодих жінок.

\section{Матеріал і методи дослідження}

У дослідженні прийняли участь молоді жінки віком 21 25 років $(n=84)$. Дослідження проводилось на базі спортивного клубу Дніпровського державного технічного університету. Основне дослідження проводилось протягом 12 місяців. Було проведено анкетування для визначення індивідуальних особливостей біологічних циклів молодих жінок. Результати показали, що більшість жінок (67-81\%) відчувають негативні зміни хворобливості в організмі та пригніченість психоемоційного стану в менструальній, передменструальній та овуляторній фазах циклу, що не дає можливість у повному обсязі відвідувати заняття фітнесом у цих фазах. У зв'язку з цим учасниці дослідження на добровільних засадах з урахуванням індивідуальних побажань були розподілені на контрольну $(n=36)$ і експериментальну $(\mathrm{n}=48)$ групи

Контрольна група (КГ) займалась базовою аеробікою, пілатесом та стретчингом без урахування фаз оваріальноменструального циклу (ОМЦ). Заняття проводились три рази на тиждень тривалістю 65-80 хвилин у зоні середньої та високої інтенсивності. Структура заняття включала підготовчу, основну та заключну частини. Частота серцевих скорочень в основній частині становила від 90 до 160 уд. 'хв ${ }^{-1}$, на піку навантаження протягом 13-15 хвилин частота серцевих скорочень становила від 140 до 160 уд. 'хв ${ }^{-1}$ Фізичне навантаження під час заняття має переважно аеробну спрямованість (35\%), силову (25\%) та танцювальну (20\%), застосовувались вправи на розтягування та корекцію фігури.
В експериментальній групі (ЕГ) дівчата відвідували заняття різними видами фітнесу відповідно до фаз ОМЦ. Заняття також проводились три рази на тиждень. В постменструальній та постовуляторній фазах займались базовою аеробікою, в овуляторній - за системою Пілатеса. Тривалість заняття пілатесом складала 55-65 хвилин, заняття проводилось у зоні середньої інтенсивності. Частота серцевих скорочень в основній частині заняття становила від 90 до 130 уд. ×хв ${ }^{-1}$. Заняття мало переважно корекційну спрямованість (45\%), для відновлення м'язового балансу пропорційно застосовувалися вправи на силу (25\%), розтяжку (25\%), а також фізичні навантаження аеробного характеру (5\%); заняття закінчувалось аутотренінгом та м'язовою релаксацією (5\%). У менструальній фазі біологічного циклу дівчата займались стретчингом. Тривалість заняття складала 45-50 хвилин, заняття проводилось у зоні низької інтенсивності. Частота серцевих скорочень в основній частині заняття становила від 90 до 120 уд. ×хв ${ }^{-1}$ Основною спрямованістю тренувальних засобів був розвиток гнучкості (50\%). Виконувалися вправи на силу (20\%) у стато-динамічному режимі скорочення м'язів. Значна кількість тренувального часу (15\%) відводилася аутотренінгу для зняття негативних психоемоційних проявів у несприятливі фази циклу. Протягом педагогічного експерименту проводився оперативний контроль психофізичного стану дівчат. При необхідності здійснювалась індивідуальна корекція програми занять.

Для визначення функціонального стану серцевосудинної системи досліджувались наступні показники: частота серцевих скорочень (ЧСС, уд.·ХВ ${ }^{-1}$ ) визначалася пальпаторним методом на сонній або променевій артерії у стані спокою; артеріальний тиск визначали медичним тонометром; час відновлення після 20 присідань за 30 с [1].

Для оцінки рівня фізичної підготовленості використовувались наступні тести: "човниковий біг 4х9 м", с; "стрибок у довжину з місця", см; "підйом тулуба в сід" за одну хвилину, кількість разів; "нахил вперед з положення сидячи", см [14].

Для визначення рівня психологічної сфери застосовувалась методика Н. Е. Водоп'янової "Оцінка задоволеності якістю життя" [8], яка дозволяє характеризувати задоволеність поточною діяльністю, благополуччям та психічним здоров'ям людини. Тестування проводилось на початку та у кінці експерименту.

Таблиця 1

Функціональні показники контрольної та експериментальної груп до та після експерименту

\begin{tabular}{|c|c|c|c|c|c|c|}
\hline Показники & $\begin{array}{l}K \Gamma, n=36 \\
\text { EГ, } n=48\end{array}$ & До експерименту, & Оцінка & Після експерименту, & Оцінка & $\mathbf{P}$ \\
\hline \multirow{3}{*}{$\begin{array}{l}\text { ЧСС у стані спокою, } \\
\text { уд. } \text { Хв }^{-1}\end{array}$} & КГ & $80,01 \pm 2,22$ & задов. & $76,03 \pm 1,25$ & задов. & $>0,05$ \\
\hline & ЕГ & $77,25 \pm 1,24$ & \multirow[t]{2}{*}{ задов. } & $69,98 \pm 1,19$ & \multirow[t]{2}{*}{ добре } & $<0,01$ \\
\hline & $\mathrm{P}$ & $>0,05$ & & $<0,01$ & & - \\
\hline \multirow{3}{*}{ АТсист, мм. рт. ст. } & $\mathrm{K} \Gamma$ & $115,06 \pm 3,08$ & \multirow{3}{*}{$\begin{array}{l}\text { оптим. } \\
\text { оптим. }\end{array}$} & $114,19 \pm 1,82$ & \multirow{3}{*}{$\begin{array}{l}\text { оптим. } \\
\text { оптим. }\end{array}$} & $>0,05$ \\
\hline & ЕГ & $117,29 \pm 3,12$ & & $115,08 \pm 3,15$ & & $<0,05$ \\
\hline & $\mathrm{P}$ & $>0,05$ & & $<0,05$ & & - \\
\hline \multirow{3}{*}{ АТдіаст, мм. рт. ст. } & $\mathrm{K} \Gamma$ & $72,30 \pm 0,86$ & оптим. & $71,10 \pm 0,72$ & оптим. & $>0,05$ \\
\hline & $\mathrm{EГ}$ & $75,30 \pm 1,22$ & \multirow[t]{2}{*}{ оптим. } & $74,15 \pm 1,33$ & \multirow[t]{2}{*}{ оптим. } & $<0,05$ \\
\hline & $\mathrm{P}$ & $>0,05$ & & $<0,05$ & & - \\
\hline \multirow{3}{*}{$\begin{array}{l}\text { Час відновлення після } \\
20 \text { присідань за } 30 \text { с, с }\end{array}$} & $\mathrm{K} \Gamma$ & $129,23 \pm 4,23$ & \multirow{3}{*}{$\begin{array}{l}\text { нижче } \\
\text { серед. } \\
\text { нижче } \\
\text { серед. }\end{array}$} & $112,63 \pm 4,50$ & \multirow{3}{*}{$\begin{array}{c}\text { нижче } \\
\text { серед. } \\
\text { вище } \\
\text { серед. }\end{array}$} & $>0,05$ \\
\hline & EГ & $125,22 \pm 3,76$ & & $89,93 \pm 2,24$ & & $<0,01$ \\
\hline & $\mathrm{P}$ & $>0,05$ & & $<0,01$ & & - \\
\hline
\end{tabular}




\section{СЛОБОЖАНСЬКИЙ НАУКОВО-СПОРТИВНИЙ ВІСНИК}

\section{Результати дослідження}

Дослідження функціонального стану молодих жінок на початку педагогічного експерименту показало, що достовірних змін між контрольною та експериментальною групами не виявлено ( $p>0,05)$.

У табл. 1 представлені зміни показників обох груп. Порівняльний аналіз функціонального стану молодих жінок контрольної та експериментальної груп показав, що відповідно до загальновизнаних норм для цього віку за період експерименту у ЕГ відбулися достовірні зміни $(p<0,05-0,01)$ у наступних показниках: АТсист., АТдіаст. мм. рт. ст.; ЧСС у стані спокою, уд. · хв$^{-1}$; часу відновлення після 20 присідань за 30 с, с. У КГ відбулися незначні зміни усіх показників ( $>>0,05)$. Найбільший вплив використання засобів різних видів фітнесу справило на показники ЧСС у стані спокою, уд.·хв ${ }^{-1}-$ з оцінки "задовільно" до "добре"; часу відновлення після 20 присідань за 30 с, с - 3 оцінки "нижче середнього" до "вище середнього".

Таблиця 2

Показники фізичної підготовленості контрольної та експериментальної груп до та після експерименту

\begin{tabular}{|c|c|c|c|c|c|c|}
\hline Тестова вправа & $\begin{array}{l}K \Gamma, n=36 \\
E \Gamma, n=48\end{array}$ & До експерименту, & Оцінка & $\begin{array}{c}\text { Після експерименту, } \\
\overline{\mathbf{X} \pm \mathbf{m}}\end{array}$ & Оцінка & $\mathbf{P}$ \\
\hline \multirow{3}{*}{$\begin{array}{l}\text { Човниковий біг } 4 \times 9 \\
\text { м, с }\end{array}$} & $\mathrm{K \Gamma}$ & $11,75 \pm 0,13$ & погано & $11,36 \pm 0,08$ & \multirow{3}{*}{$\begin{array}{l}\text { незадов. } \\
\text { задов. }\end{array}$} & $>0,05$ \\
\hline & $\mathrm{E} \Gamma$ & $11,71 \pm 0,14$ & погано & $11,18 \pm 0,06$ & & $<0,01$ \\
\hline & $\mathrm{P}$ & $>0,05$ & & $<0,05$ & & - \\
\hline \multirow{3}{*}{$\begin{array}{l}\text { Стрибок у довжину з } \\
\text { місця, см }\end{array}$} & $\mathrm{K} \Gamma$ & $159,75 \pm 2,63$ & погано & $169,51 \pm 2,87$ & \multirow{3}{*}{$\begin{array}{l}\text { незадов. } \\
\text { задов. }\end{array}$} & $>0,05$ \\
\hline & $\mathrm{E \Gamma}$ & $162,74 \pm 2,62$ & погано & $179,12 \pm 3,15$ & & $<0,05$ \\
\hline & $\mathrm{P}$ & $>0,05$ & & $<0,01$ & & - \\
\hline \multirow{3}{*}{$\begin{array}{l}\text { Піднімання тулуба } \\
\text { в сід з положення } \\
\text { лежачи на спині, } \\
\text { кількість разів }\end{array}$} & КГ & $26,05 \pm 2,22$ & незадов. & $37,24 \pm 1,88$ & \multirow{3}{*}{$\begin{array}{c}\text { задов. } \\
\text { відмінно }\end{array}$} & $>0,05$ \\
\hline & $\mathrm{E} \Gamma$ & $27,55 \pm 1,85$ & незадов. & $46,15 \pm 2,20$ & & $<0,05$ \\
\hline & $P$ & $>0,05$ & & $<0,001$ & & - \\
\hline \multirow{3}{*}{$\begin{array}{l}\text { Нахил вперед } 3 \\
\text { положення сидячи, см }\end{array}$} & $\mathrm{K} \Gamma$ & $12,05 \pm 1,14$ & незадов. & $16,52 \pm 0,63$ & \multirow{3}{*}{$\begin{array}{c}\text { добре } \\
\text { відмінно }\end{array}$} & $>0,05$ \\
\hline & $\mathrm{E} \Gamma$ & $12,45 \pm 1,05$ & незадов. & $19,65 \pm 0,90$ & & $<0,01$ \\
\hline & $\mathrm{P}$ & $>0,05$ & & $<0,01$ & & - \\
\hline
\end{tabular}

Таблиця 3

Показники рівня "Оцінки задоволеності якістю життя" контрольної та експериментальної груп до та після експерименту

\begin{tabular}{|c|c|c|c|c|}
\hline Показники & $\begin{array}{l}K \Gamma, n=36 \\
E \Gamma, n=48\end{array}$ & До експерименту, & Після експерименту, & $\mathbf{P}$ \\
\hline \multirow{3}{*}{ Робота, кар’єра } & $\mathrm{K} \Gamma$ & $22,02 \pm 1,19$ & $25,80 \pm 1,50$ & $>0,05$ \\
\hline & ЕГ & $22,40 \pm 1,17$ & $29,31 \pm 1,44$ & $<0,05$ \\
\hline & $\mathrm{P}$ & $>0,05$ & $<0,01$ & - \\
\hline \multirow{3}{*}{ Особисті досягнення і прагнення } & КГ & $23,45 \pm 1,28$ & $26,72 \pm 1,36$ & $>0,05$ \\
\hline & EГ & $22,48 \pm 1,17$ & $30,12 \pm 1,72$ & $<0,01$ \\
\hline & $\mathrm{P}$ & $>0,05$ & $<0,01$ & - \\
\hline \multirow{3}{*}{ Здоров’я } & $\mathrm{K} \Gamma$ & $21,35 \pm 1,26$ & $29,45, \pm 1,74$ & $<0,05$ \\
\hline & ЕГ & $21,11 \pm 0,99$ & $35,65 \pm 0,75$ & $<0,01$ \\
\hline & $\mathrm{P}$ & $<0,05$ & $<0,001$ & - \\
\hline \multirow{3}{*}{ Спілкування з друзями (близькими) } & $\mathrm{K \Gamma}$ & $28,20 \pm 1,73$ & $32,05 \pm 0,88$ & $>0,05$ \\
\hline & ЕГ & $28,32 \pm 1,49$ & $35,75 \pm 0,73$ & $<0,01$ \\
\hline & $\mathrm{P}$ & $>0,05$ & $<0,01$ & - \\
\hline \multirow{3}{*}{ Підтримка } & $\mathrm{K \Gamma}$ & $27,09 \pm 1,29$ & $29,05 \pm 0,84$ & $>0,05$ \\
\hline & ЕГ & $26,55 \pm 1,37$ & $31,45 \pm 1,12$ & $<0,01$ \\
\hline & $P$ & $>0,05$ & $<0,01$ & - \\
\hline \multirow{3}{*}{ Оптимістичність } & $\mathrm{K \Gamma}$ & $24,04 \pm 1,32$ & $29,45 \pm 0,95$ & $<0,05$ \\
\hline & ЕГ & $25,25 \pm 1,53$ & $34,15 \pm 1,05$ & $<0,01$ \\
\hline & $P$ & $<0,05$ & $<0,001$ & - \\
\hline \multirow{3}{*}{ Напруженість } & КГ & $24,90 \pm 1,40$ & $28,55 \pm 1,21$ & $>0,05$ \\
\hline & EГ & $26,05 \pm 1,56$ & $34,71 \pm 1,03$ & $<0,05$ \\
\hline & $\mathrm{P}$ & $>0,05$ & $<0,01$ & - \\
\hline \multirow{3}{*}{ Самоконтроль } & $\mathrm{K} \Gamma$ & $21,32 \pm 1,37$ & $25,07 \pm 1,30$ & $>0,05$ \\
\hline & ЕГ & $22,45 \pm 1,58$ & $28,51 \pm 1,46$ & $<0,01$ \\
\hline & $\mathrm{P}$ & $>0,05$ & $<0,01$ & - \\
\hline \multirow{3}{*}{ Негативні емоції } & $\mathrm{K \Gamma}$ & $23,52 \pm 1,43$ & $26,29 \pm 1,22$ & $>0,05$ \\
\hline & ЕГ & $24,91 \pm 1,33$ & $28,57 \pm 1,26$ & $>0,05$ \\
\hline & $P$ & $>0,05$ & $>0,05$ & - \\
\hline \multirow{3}{*}{ Індекс якості життя } & $\mathrm{K \Gamma}$ & $23,97 \pm 1,28$ & $28,03 \pm 1,39$ & $>0,05$ \\
\hline & $\mathrm{E \Gamma}$ & $24,43 \pm 1,54$ & $31,94 \pm 1,48$ & $<0,05$ \\
\hline & $P$ & $>0,05$ & $<0,01$ & - \\
\hline
\end{tabular}




\section{SLOBOZANS'KIJ NAUKOVO-SPORTIVNIJ VISNIK}

Аналіз показників фізичної підготовленості молодих жінок виявив, що на початку педагогічного експерименту достовірних змін між контрольною та експериментальною групами не виявлено ( $>>0,05)$.

У табл. 2 представлені зміни фізичної підготовленості обох груп. У ході дослідження в експериментальній групі відбулися достовірні зміни ( $<<0,05-0,01)$ наступних показників: "човниковий біг 4х9 м", с; "стрибок удовжину з місця", см; "підйом тулуба в сід" за одну хвилину, кількість разів; "нахил вперед з положення сидячи", см. Аналіз результатів контрольної групи показав, що вони також покращились, але недостатньо $(p>0,05)$. Після узагальнення встановлюється, що найбільші зміни відбулися у показниках тесту силової витривалості м'язів черевного пресу та гнучкості, а саме з оцінки "незадовільно" до оцінки "відмінно".

Аналіз показників рівня "Оцінки задоволеності якістю життя" виявив, що достовірних змін між контрольною та експериментальною групами на початку експерименту не виявлено ( $p>0,05)$.

У табл. 3 представлені зміни рівня "Оцінки задоволеності якістю життя" жінок контрольної та експериментальної груп. Як свідчать дані таблиці, за період педагогічного експерименту відбулися позитивні зміни в обох групах. Але необхідно відзначити, що у контрольній груп відбулися недостовірні зміни ( $>0,05)$, за винятком шкал "Здоров'я" і "Оптимістичність" $(p<0,05)$. В експериментальній групі всі показники, які досліджувалися, істотно змінилися $(p<0,05-0,01)$, за винятком показника "Негативні емоції" ( $>>0,05)$, а саме: поліпшилося відношення до своєї діяльності, самоконтроль, самооцінка, сприйняття здоров'я, підтримка друзів, оптимістичність при одночасному зменшенні напруженості та ступеня прояву негативних емоцій. У результаті дослідження виявлено, що особиста оцінка задоволеності якістю життя дівчатами ЕГ суттєво $(p<0,05)$ відрізняється від дівчат КГ $(p>0,05)$.
Таким чином, розроблена методика поєднання різних видів фітнесу з урахуванням оваріально-менструального циклу є ефективним засобом покращення показників фізичної працездатності, фізичної підготовленості та психічного здоров'я молодих жінок.

\section{Висновки / Дискусія}

Результати проведеного дослідження дали змогу підтвердити та доповнити відомі наукові розробки, а також отримати нові дані в аспекті проблеми, що вивчалася. У результаті дослідження підтверджується наукові дані [4; 12; 19; 20] про те, що заняття фітнесом підвищують фізичну підготовленість та фізичну працездатність, доповнено дані [10] про індивідуально-психологічні можливості жінок молодого віку на заняттях оздоровчим фітнесом.

Узагальнюючи результати проведеного дослідження, можна констатувати, що у дослідженні набули подальшого розвитку наукові дані про необхідність вираховування біологічної циклічності функцій жіночого організму при плануванні фізичних навантажень, підборі вправ різної спрямованості та способи їх дозування у фізкультурнооздоровчому процесі [6; 16].

Застосування авторської методики поєднання різних видів фітнесу (базової аеробіки, пілатесу та стретчингу), яка базується на підборі оптимальних параметрів фізичних навантажень у різні фази ОМЦ, сприяє поліпшенню психофізичного стану молодих жінок. Результати дослідження доповнюють теорію та методику фізичного виховання новими уявленнями про можливість модернізації фізкультурно-оздоровчих занять.

Перспективи подальших досліджень полягають у визначені показників рівня тривожності молодих жінок, які займаються оздоровчим фітнесом у різних фазах оваріально-менструального циклу.

Конфлікт інтересів. Автори заявляють, що немає конфлікту інтересів, який може сприйматися таким, що може завдати шкоди неупередженості статті. Джерела фінансування. Ця стаття не отримала фінансової підтримки від державної, громадської або комерційної організацій.

\section{Список посилань}

1. Апанасенко, Г.Л. (1992), Эволюция биоэнергетики и здоровье человека, С-Пб.

2. Беляк, Ю., Грибовська, І., Музика, Ф., Іваночко, В., Чеховська, Л. (2018), Теоретико-методичні основи оздоровчого фітнесу: навч. посіб., Львів.

3. Дутчак, М.В. (2015), "Парадигма оздоровчої рухової активності: теоретичне обґрунтування і практичне застосування", Теорія $і$ методика фізичного виховання і спорту, № 2, С. 44-52.

4. Іваночко, В.В., Маланчук, Г.Г. (2018), "Вплив оздоровчих занять аеробікою на фізичну працездатність жінок першого періоду зрілого віку", Актуальні питання вдосконалення системи фізичного виховання і спортивної роботи у вищій школі. Збірник наукових праць за матеріалами I науково-практичної конференції з міжнародною участю, Ужгород, С. 16-18.

5. Кашуба, В., Гончарова, Н., Дудко, М., Мартинюк, О. (2016), "До питання підвищення ефективності фізкультурно-оздоровчих занять різних груп населення", Молодіж. наук. вісн. Східноєвроп. нац. ун-ту ім. Лесі Українки, Вип. 24, С. 9-14

6. Луковська, О., Сологубова, С. (2015), "Поєднання різних видів фітнесу в фізкультурно-оздоровчих заняттях з жінками першого зрілого віку", Спортивний вісник Придніпров'я, № 2, С. 103-108.

7. Мартынюк, О. (2016), "Показатели физического состояния женщин, занимающихся оздоровительной аэробикой", Слобожанський науково-спортивний вісник, № 4(54), С. 73-78.

8. Никифоров, Г.С. (2006), Психология здоровья: учебник для вузов, СПб.

9. Пірогова, К., Микитчик, О. (2019), "Фізичний стан жінок першого періоду зрілого віку, які займаються аквафітнесом", Спортивний вісник Придніпров'я, № 3, С. 149-157

10. Пястолова, Н.Б. (2019), "Фитнес-тренировки: физическое и психоэмоциональное состояние женщин", Физическая культура. Спорт. Туризм. Двигательная рекреация, № 4, С. 138-143.

11. Романенко, Н.И. (2018), "Методика комплексного использования базовой и силовой аэробики в физической подготовке женщин 25-35 лет", Физическая культура, спорт - наука и практика, №1, С. 52-56.

12. Романюк, В. (2015), "Вплив фітнес-програм на функціональні можливості серцево-судинної системи студенток", Молодіжний науковий вісник Східноєвропейського національного університету імені Лесі Українки. Фізичне виховання і спорт, Вип.17, С. 61-66.

13. Сайкина, Е.Г. (2016), "Фитнес-технологии: понятие, разработка и специфические особенности", Вестник спортивной науки, № 1, C. 50-53.

14. Сергієнко, Л.П. (2001), Комплексне тестування рухових здібностей людини: навчальний посіб,, Миколаїв.

Шишкіна, О., Бейгул, І., Муллагільдіна, А. (2019), "Вплив занять різними видами фітнесу з урахуванням оваріальноменструального циклу на психофізичний стан молодих жінок", Слобожанський науково-спортивний вісник, № 6(74), С. 5156, doi:10.15391/snsv.2019-6.008
Shishkina, O., Beihul, I. \& Mullagildina, A. (2019), "Effect of different kinds of fitness based on the ovarian-menstrual cycle on the psychophysical state of young women", Slobozans'kij naukovo-sportivnij visnik, No. 6(74), pp. 51-56, doi:10.15391/ snsv.2019-6.008 


\section{СЛОБОЖАНСЬКИЙ НАУКОВО-СПОРТИВНИЙ ВІСНИК}

15. Сивак, О., Прокопенко, О., Цикалюк, О., Полікарчук, І. (2019), Здоров'я жінок в Україні: права, можливості та рекомендації: посіб., Київ.

16. Сологубова, С. (2016), "Алгоритм побудови індивідуальнихпрограм в кондиційному тренуванні жінок", Спортивний вісник Придніпров’я, № 1, C. 121-125.

17. Сутула, В., Луценко, Л., Жадан, А., Сутула, А. (2018), "Фізичний фітнес як один із напрямів історичного розвитку фізичної культури", Слобожанський науково-спортивний вісник, № 4(65), С.63-66.

18. Усачев, Ю.А. (2015), Физкультурно-оздоровительные технологии формирования фитнес-культуры студентов: учебное пособие, Киев.

19. Шишкіна, О.М., Бейгул, І.О. (2014), "Вплив занять фітнес-аеробікою на функціональні показники жінок", Фізична культура, спорт та здоров'я нації: збірник наукових праць Вінницький державний педагогічний університет імені Михайла Коцюбинського, Вінниця, Вип. 17, С. 343-347.

20. Шишкіна, О.М., Муллагільдіна, А.Я. (2015), "Зміни рівня фізичної підготовленості жінок, які займаються фітнес-аеробікою", Науковий Часопис Національного педагогічного університету імені М. П. Драгоманова. Серія №15. "Науково-педагогічні проблеми фізичної культури (Фізична культура і спорт)", № 3К1(56)15, С. 393-395.

21. Armstrong, T. (2011), "Physical activity and health benefits", 14th World Conference Sport for All 20-23.09.2011: Abstracts Book, Beijing, pp. 46-49.

22. Crossley, J. (2012), Personal training: Theory and Practice Routledge.

23. Stewart, A. \& Sutton, L. (2012), Body composition in sport, exercise and health, Routledge, London.

24. Synytsya, T.O., Shesterova, L.E. \& Synytsya, S.V. (2014), "The popular activities of health aerobics among women of Ukraine", Stiinta culturii fizice: Pregatire professional antrenament sportive educatie fizica recuperare recreatie, Chişinău, No. 19(3), pp. $101-107$.

25. Yarmak, O., Galan, Y., Hakman, A., Dotsyuk, L. \& Teslitskyi, Y. (2017), "The use of modern means of health improving fitness during the process of physical education of student youth", Journal of Physical Education and Sport, No. 17(3), pp. 1935-1940.

Стаття надійшла до редакції: 08.11.2019 р.

Опубліковано: 30.12.2019 р.

Аннотация. Елена Шишкина, Игорь Бейгул, Алла Муллагильдина. Влияние занятий различными видами фитнеса с учетом овариально-менструального цикла на психофизическое состояние молодых женщин. Цель: определить влияние занятий различными видами фитнеса с учетом овариально-менструального цикла на психофизическое состояние молодых женщин. Материал и методы: в исследовании приняли участие молодые женщины в возрасте 21-25 лет (n=84), которые были распределены на две группы: контрольную (КГ, $n=36)$ и экспериментальную (ЭГ, $n=48)$. Контрольная группа занималась базовой аэробикой, пилатесом и стретчингом без учета фаз овариально-менструального цикла, экспериментальная - различными видами фитнеса в соответствии с фазами ОМЦ. Занятия проводились 3 раза в неделю, исследование продолжалось в течение 12 месяцев. Определяли функциональные возможности по следующим показателям: частота сердечных сокращений в состоянии покоя, артериальное давление, время восстановления после 20 приседаний за 30 с; физическую подготовленность по следующим показателям: "челночный бег 4x9 м", с; "прыжок в длину с места", см; "подъем туловища в сед" за одну минуту, количество раз; "наклон вперед из положения сидя", см. Уровень проявления психологической сферы определялся по методике Н. Э. Водопьяновой "Оценка удовлетворенности качеством жизни". Результаты: сравнительный анализ обеих групп показал, что в ЭГ произошло достоверное (р<0,05$0,01)$ улучшение функциональных показателей. Наибольшее влияние использования средств различных видов фитнеса оказало на показатели ЧСС в состоянии покоя, уд. минн-1: с оценки "удовлетворительно" до оценки "хорошо"; время восстановления после 20 приседаний за 30 c, с: с оценки "ниже среднего" до "выше среднего". Показатели физической подготовленности в ЭГ по сравнению с КГ также значительно улучшились $(p<0,05-0,01)$. Установлено, что наибольшие изменения произошли в показателях теста силовой выносливости мышц брюшного пресса и гибкости: с оценки "неудовлетворительно" до "отлично". Выявлено, что личная оценка удовлетворенности качеством жизни ЭГ существенно ( $p<0,05-0,01)$ отличается от КГ. У женщин ЭГ улучшилось отношение к своей деятельности, самоконтроль, самооценка, восприятие здоровья, поддержка друзей и оптимистичность при одновременном уменьшении напряженности и степени проявления негативных эмоций. Выводы: использование оздоровительной методики сочетания различных видов фитнеса благоприятно отразилось на психофизическом состоянии молодых женщин. Существует возможность применения разработанной методики в практике оздоровительных тренировок.

Ключевые слова: оздоровительный фитнес, психофизическое состояние, овариально-менструальный цикл, молодые женщины, тренировочные нагрузки.

Abstract. Olena Shishkina, Igor Beihul \& Alla Mullagildina. Effect of different kinds of fitness based on the ovarianmenstrual cycle on the psychophysical state of young women. Purpose: to determine the effect of different kinds of fitness, based on the ovarian-menstrual cycle on the psychophysical state of young women. Material \& Methods: the research involved young women aged 21-25 years $(n=84)$, which are divided into two groups: control (CG, $n=36)$ and experimental ( $E G, n=48)$. The control group was doing basic aerobics, pilates and stretching without taking into account the phases of the ovarian-menstrual cycle, experimental was doing different kinds of fitness according to the phases of the OMC. Exercises were conducted 3 times a week, the research lasted for 12 months. Functional capabilities were determined according to the following indicators: resting heart rate, blood pressure, recovery time after 20 squats in 30 s; physical fitness by the following indicators: "shuttle running $4 \times 9 \mathrm{~m}$ ", with; "Long jump from place", cm; "Lifting the torso into the saddle" in one minute, the number of times; "Leaning forward from sitting position", cm Level of demonstration of psychological sphere according to the method of N. E. Vodopianova "Assessment of satisfaction with quality of life". Results: a comparative analysis of both groups showed that there was a significant $(p<0,05-0,01)$ improvement in functional capacity in the EG. The greatest impact of the use of various fitness tools had on resting heart rate, bit.min"-1: from a rating of "fair" to "good"; recovery time after 20 squats in 30 s, from: 'below average' to 'above average'. Physical fitness in the EG compared to CG also improved significantly $(p<0,05-0,01)$. It was found that the biggest changes occurred in the indices of the endurance test of the abdominal muscles and flexibility: from the rating "unsatisfactory" to "excellent". It was found that the personal assessment of the quality of life satisfaction with EG was significantly $(p<0,05-0,01)$ different from CG. The former improved their attitude, self-control, self-esteem, health perception, support of friends and optimism while reducing tensions and expressing negative emotions. Conclusions: the use of the wellness method of combining different kinds of fitness has a positive effect on the psychophysical state of young women. There is an opportunity to apply the developed methodology to the practice of wellness training.

Keywords: wellness fitness, psychophysical state, ovarian-menstrual cycle, young women, training load.

\section{References}

1. Apanasenko, G.L. (1992), Evolyutsiya bioenergetiki i zdorove cheloveka [The evolution of bioenergy and human health], St. Petersburg. (in Russ.)

2. Belyak, Y., Gribovskaya, I., Music, F., Ivanochko, V. \& Chekhovska, L. (2018), Teoretyko-metodychni osnovy ozdorovchoho fitnesu [Theoretical and methodological foundations of wellness fitness], Lviv. (in Ukr.)

Шишкіна, О., Бейгул, І., Муллагільдіна, А. (2019), "Вплив занять різними видами фітнесу з урахуванням оваріальноменструального циклу на психофізичний стан молодих жінок", Слобожанський науково-спортив 56, doi:10.15391/snsv.2019-6.008
Shishkina, O., Beihul, I. \& Mullagildina, A. (2019), "Effect of different kinds of fitness based on the ovarian-menstrual cycle on the psychophysical state of young women", Slobozans 'kij naukovo-sportivnij visnik, No. 6(74), pp. 51-56, doi:10.15391/ snsv.2019-6.008 


\section{SLOBOZANS'KIJ NAUKOVO-SPORTIVNIJ VISNIK}

3. Dutchak, M.V. (2015), "The paradigm of wellness motor activity: theoretical grounding and practical application", Teoriia imetodyka fizychnoho vykhovannia i sportu, No. 2, pp. 44-52. (in Ukr.)

4. Ivanochko, V.V. \& Malanchuk, G.G. (2018), "The Impact of Wellness Aerobics on the Physical Performance of Women in the First Mature Age", Aktualni pytannia vdoskonalennia systemy fizychnoho vykhovannia i sportyvnoi roboty u vyshchii shkoli, Collection of scientific papers on the materials of the First Scientific Conference with International Participation, Uzhgorod, pp. 16-18. (in Ukr.)

5. Kashuba, V., Goncharova, N., Dudko, M. \& Martyniuk, O. (2016), "On the Issue of Improving the Efficiency of Physical Culture and Health Activities of Different Populations", Molodizh. nauk. visn. Skhidnoievrop. nats. un-tu im. Lesi Ukrainky, Iss. 24, pp. 9-14. (in Ukr.)

6. Lukovskaya, O. \& Sologubova, S. (2015), "Combination of different types of fitness in fitness classes with women of the first mature age", Sportyvnyi visnyk Prydniprov'ia, No. 2, pp. 103-108. (in Ukr.)

7. Martynyuk, O. (2016), "Indicators of the physical condition of women engaged in health aerobics", Slobozans 'kij naukovo-sportivnij visnik, No. 4 (54), pp. 73-78.

(in Russ.) Russ.)

Nikiforov, G.S. (2006), Psikhologiya zdorovya: uchebnik dlya vuzov [Health Psychology: a textbook for universities], St. Petersburg. (in

9. Pirogov, K. \& Mykytchyk, O. (2019), "Physical state of aqua fitness women of the first adult age", Sportyvnyi visnyk Prydniprov'ia, No. 3, pp. 149-157. (in Ukr.)

10. Pyastolova, N.B. (2019), "Fitness training: the physical and psycho-emotional state of women", Fizicheskaya kultura. Sport. Turizm. Dvigatelnaya rekreatsiya, No. 4, pp. 138-143. (in Russ.)

11. Romanenko, N.I. (2018), "Methods of the integrated use of basic and power aerobics in the physical preparation of women 25-35 years old", Fizicheskaya kultura, sport - nauka i praktika, No. 1, pp. 52-56. (in Russ.)

12. Romanyuk, V. (2015), "The Impact of Fitness Programs on the Functionality of the Cardiovascular System of Female Students", Molodizhnyi naukovyi visnyk Skhidnoievropeiskoho natsionalnoho universytetu imeni Lesi Ukrainky. Fizychne vykhovannia i sport, Issue 17, pp. 61-66. (in Ukr.) Russ.)

13. Saykina, E.G. (2016), "Fitness technologies: concept, development and specific features", Vestnik sportivnoy nauki, No. 1, pp. 50-53. (in

14. Sergienko, L.P. (2001), Kompleksne testuvannia rukhovykh zdibnostei liudyny [Comprehensive testing of human motor abilities], Mykolaiv. (in Ukr.)

15. Sivak, O., Prokopenko, O., Tsykalyuk, O. \& Polycarchuk, I. (2019), Zdorov'ia zhinokv Ukraini: prava, mozhlyvosti ta rekomendatsii [Women's Health in Ukraine: Rights, Opportunities and Recommendations], Kiev. (in Ukr.)

16. Sologubova, S. (2016), "An algorithm for constructing individual programs in women's conditioning training", Sportyvnyi visnyk Prydniprov'ia, No. 1, pp. 121-125. (in Ukr.)

17. Sutula, V., .Lutsenko, L., Zhadan, A., Sutula, A (2018), "Physical fitness as the historical development of physical culture", Slobozans'kij naukovo-sportivnij visnik, No. 4 (65), pp. 63-66. (in Ukr.)

18. Usachev, Yu.A. (2015), Fizkulturno-ozdorovitelnye tekhnologii formirovaniya fitnes-kultury studentov [Fitness and fitness technologies for the formation of students' fitness culture], Kiev. (in Russ.)

19. Shishkina, O.M. \& Beygul, I.O. (2014), "The Impact of Fitness Aerobics on the Functional Indicators of Women", Fizychna kultura, sport ta zdorov'ia natsii, Issue 17, pp. 343-347. (in Ukr.)

20. Shishkina, O.M. \& Mulagildina, A.Ya. (2015), "Changes in the fitness level of women engaged in fitness aerobics", Naukovyi Chasopys Natsionalnoho pedahohichnoho universytetu imeni M. P. Drahomanova. Seriia №15. "Naukovo-pedahohichni problemy fizychnoi kultury (Fizychna kultura i sport)", No. ZK1(56)15, pp. 393-395. (in Ukr.)

21. Armstrong, T. (2011), "Physical activity and health benefits", 14th World Conference Sport for All 20-23.09.2011: Abstracts Book, Beijing, pp. $46-49$

22. Crossley, J. (2012), Personal training: Theory and Practice Routledge.

23. Stewart, A. \& Sutton, L. (2012), Body composition in sport, exercise and health, Routledge, London.

24. Synytsya, T.O., Shesterova, L.E. \& Synytsya, S.V. (2014), "The popular activities of health aerobics among women of Ukraine", Stiinta culturii fizice: Pregatire professional antrenament sportive educatie fizica recuperare recreatie, Chișinău, No. 19(3), pp. 101-107.

25. Yarmak, O., Galan, Y., Hakman, A., Dotsyuk, L. \& Teslitskyi, Y. (2017), "The use of modern means of health improving fitness during the process of physical education of student youth", Journal of Physical Education and Sport, No. 17(3), pp. 1935-1940.

Received: 08.11.2019.

Published: 30.12 .2019

\section{Відомості про авторів / Information about the Authors}

Шишкіна Олена Миколаївна: старший викладач; Дніпровський державний технічний університет, вул. Дніпробудівська 2, Кам'янське, 51900, Україна.

Шишкина Елена Николаевна: старший преподаватель; Днепровский государственный технический университет, ул. Днепростроевская 2, Каменское, 51900, украина.

Olena Shishkina: senior lecturer; Dnieper State Technical University, Dneprostroevskaya str. 2, Kamenskoye, 51900, Ukraine.

ORCID.ORG/0000-0002-6755-138X

E-mail: olefirshishkina@gmail.com

Бейгул Ігор Олегович: к. фіз. вих.; Дніпровський державний технічний університет, вул. Дніпробудівська 2, Кам'янське, 51900, Україна.

Бейгул Игорь Олегович: к. физ. восп.; Днепровский государственный технический университет, ул. Днепростроевская 2, Каменское, 51900, Украина.

Igor Beihul: PhD (Physical Education and Sport); Dnieper State Technical University, Dneprostroevskaya str. 2, Kamenskoye, 51900, Ukraine.

ORCID.ORG/0000-0002-3892-6023

E-mail: bejippon@gmail.com

Муллагільдіна Алла Ядікарівна: к. пед. н., доцент; Харківська державна академія фізичної культури: вул. Клочківська, 99, г. Харків, 61058, Україна

Муллагильдина Алла Ядикаровна: к. пед. н., доцент; Харьковская государственная академия физической культуры: ул. Клочковская 99, г. Харьков, 61058, Украина.

Alla Mullagildina: PhD(Pedagogical), Associate Professor; Kharkiv State Academy of Physical Culture, Klochkivska 99, Kharkiv, 61058, Ukraine.

ORCID.ORG/0000-0002-9232-6387

E-mail: mullagildinaalla@gmail.com

Шишкіна, О., Бейгул, І., Муллагільдіна, А. (2019), "Вплив занять різними видами фітнесу 3 урахуванням оваріальноменструального циклу на психофізичний стан молодих жінок", Слобожанський науково-спортивний вісник, № 6(74), С. 51-
56, doi:10.15391/snsv.2019-6.008
Shishkina, O., Beihul, I. \& Mullagildina, A. (2019), "Effect of different kinds of fitness based on the ovarian-menstrual cycle on the psychophysical state of young women", Slobozans'kij naukovo-sportivnij visnik, No. 6(74), pp. 51-56, doi:10.15391/ snsv.2019-6.008 


\section{Современные методы контроля и оценки текущего функционального состояния спортсменов в различных видах единоборств}

\author{
Владимир Ревенко \\ Ярославна Пугач ${ }^{1}$ \\ Валерий Друзь ${ }^{1}$ \\ Вадим Артемьев ${ }^{2}$
}

\author{
'Харьковская государственная академия физической \\ культуры, Харьков, Украина \\ ${ }^{2}$ Коммунальное учреждение Детско-юношеская \\ спортивная школа № 8, Харьков, Украина
}

Цель: разработка бесконтактной системы контроля в реальном масштабе времени текущего функционального состояния спортсмена.

Материал и методы: анализ научно-методической литературы по проблемам выполняемых исследований; биомеханический анализ кинематических и динамических характеристик двигательных действий спортсмена при выполнении соревновательных упражнений; методы математической статистики; компьютерное математическое моделирование.

Результаты: рассмотрены и проанализированы существующие методы оценки функционального состояния организма в период тренировочной и соревновательной деятельности спортсмена, на основании чего определены требования к построению метода бесконтактного контроля функционального состояния спортсмена.

Выводы: контроль функционального состояния спортсменов-единоборцев в настоящее время осуществляется современной аппаратурой с высокой степенью точности и оперативностью обработки информации, но только в контактном режиме, что исключает возможность оперативного контроля текущего состояния спортсмена в период проведения им поединка. Исследование биомеханики движения кинематических звеньев конечностей и статической рабочей позы по материалам видеозаписи движений спортсмена позволило установить зависимость протекания динамических усилий, определяющих скорость перемещения биокинематических пар, что легло в основу разработанного бесконтактного метода оценки меры усталости спортсмена непосредственно в период ведения поединка. Современная техника видеорегистрации, компьютерного обеспечения и установленных закономерностей кинематических перемещений при различном статическом напряжении рабочей позы позволили достичь поставленную цель.

Ключевые слава: спортсмены, единоборцы, бесконтактный контроль, статическое напряжение, динамические усилия.

\section{Введение}

Развитие большого количества разнообразных видов единоборств, представляющих различные школы, вовлекающие в занятия в них обширный и крайне разнообразный контингент лиц, разных по возрасту, полу, конституциональной структуре соматотипов требует глубоких теоретических исследований, определяющих допустимые нормы физических нагрузок, построения оптимальных режимов тренировочного процесса, оценки соответствующей двигательной одаренности для занятий конкретным видом единоборств, направленных на достижение высокого уровня спортивного мастерства. Такого рода направленность исследований предполагает необходимость решения достаточно серьезных и объемных организационных задач по проведению мониторинга контингента лиц желающих и уже занимающихся выбранным видом спорта.

В последние десятилетия эта проблема стала характерной для многих видов спорта, но достаточно обоснованных теоретических разработок в этом направлении нет. Одной из исключительно важных задач, решение которой является первостепенной, состоит в определении допустимых нагрузок, обоснованных на учете индивидуального биологического возраста, отражающего время созревания морфо-функциональных систем организма [14]. Сущность проблемы состоит в том, что наблюдаемые анатомо-морфологические аспекты изменений в организме при неадекватных нагрузках в конечном счете влияют на репродуктивную функцию организма, что влечет проблему здоровья последующего поколения [2; 4].

Отсутствие фундаментальных системных исследований в этой области определяет актуальность поиска решения задач, направленных на изучение адаптационных процессов как для спорта высоких достижений, так и практического здравоохранения.

Связь исследования с научными программами, планами, темами. Исследования проводились в соответствии с темами НИР Харьковской государственной академии физической культуры "Психо-сенсорная регуляция двигательной деятельности спортсменов в ситуативных видах спорта" (номер госрегистрации 0116U008943); "Теоретико-методические основы совершенствования тренировочного процесса и соревновательной деятельности в структуре многолетней подготовки спортсменов" (номер госрегистрации 0111U001168).

Цель исследования: разработать бесконтактную систему контроля текущего функционального состояния спортсменов в ситуативных видах спорта.

\section{Материал и методы исследования}

Материалы: данные видеосъемок поединков выступления спортсменов различной квалификации, занимающихся единоборствами.

Методы исследования: анализ и обобщение научноменные методы контроля и оценки текущего функционального состояния спортсменов в различных видах единоборств", Слобожанський науково-спортивний вісник, № 6(74), С. 5762, doi: 10.15391/snsv.2019-6.009
Revenko, V., Puhach, Ya., Druz, V. \& Artemiev, V. (2019), "Modern methods of monitoring and evaluating the current functiona state of athletes in various types of martial arts", Slobozans 'kij naukovo-sportivnij visnik, No. 6(74), pp. 57-62, doi:10.15391/ snsv.2019-6.009 


\section{SLOBOZANS'KIJ NAUKOVO-SPORTIVNIJ VISNIK}

методической литературы; биомеханический анализ видеоматериалов спортивных поединков спортсменов, метод математической компьютерной аппроксимации кинематических перемещений центров масс отдельных звеньев тела и общего центра массы тела; графическое построение результатов исследований в признаковых семантических пространствах с введенной в них единой мерой сопоставляемых характеристик; метод клинической антропометрии по М. Я. Брейтману.

\section{Результаты исследования}

Организация отбора с целью отдаленного долгосрочного планирования предполагает обязательную паспортизацию у индивида физического развития, физического состояния, истинного биологического возраста, хронологического возраста, индивидуальных особенностей строения соматотипа, донозологические предрасположенности к соответствующим конституциональным заболеваниям, филогенетической предрасположенности к определенным формам двигательной деятельности и уровень соревновательной надежности.

Составление такого паспорта лиц занимающихся единоборствами стало возможным благодаря методам, которые разработаны в Харьковской государственной академии физической культуры и нашли свое применение в проводимых диссертационных исследованиях $[1 ; 5$; $11]$.

На основании антропометрических данных и их последующей обработки особое внимание уделялось весу индивида отнесенному к популяционному среднестатистическому его показателю для каждого конкретного возраста. Во всех видах единоборств эта задача существенно упрощается благодаря наличию весовых категорий в этих видах спорта, что позволило в каждой весовой категории собрать от 30 до 100 обследуемых спортсменов из соответствующих весовых категорий.

Наличие данных о весе спортсмена и его данных о биокинематических характеристиках структуры строения соматотипа позволяют точно определять общий центр масс тела, центр масс каждого биокинематического звена, что дает возможность при наличии современной компьютерной техники, необходимых программ обработки видеоматериалов и современной техники видеорегистрирующих средств определить энергетические затраты спортсмена на выполнение двигательной деятельности непосредственно в момент осуществления поединка. Характерная особенность кинематики движения состоит в том, что по мере утомления наблюдается рост неточности техники выполняемых приемов по показателям временных, пространственных и силовых характеристик.

Скорость развития этих изменений зависит от исходного состояния, определяющего потенциальные возможности спортсмена, и интенсивности осуществления им двигательной деятельности. Данные характеристики носят общий характер их протекания у всех спортсменов, но имеют строго индивидуальную обособленность у каждого из них.

Для построения метода дистанционного бесконтактного контроля текущего состояния единоборца необходимо при его паспортизации физического развития и физического состояния установить закономерности особенностей индивидуального проявления динамики протекания утомления как фактора временного снижения работоспособности от характера ее выполнения. Любой двигательный акт связан с обязательным присутствием таких составляющих компонентов, как физическое напряжение статического усилия, определяющего рабочую позу, и динамические усилия, обеспечивающие кинематику выполняемых локомоций.

Зная массу тела и место нахождения его в процессе выполнения движения тела, определяется выполняемая работа по его перемещению. Непосредственные расчеты показывают, что выполненная работа оказывается меньше, чем действительная затрата энергетического потенциала, отражающего меру текущей потери работоспособности спортсмена. Этот факт объясняется тем, что значительное количество потери энергии уходит на статическое напряжение, обеспечивающее рабочую позу выполняемых локомоций. В этот расход потенциального энергетического запаса входят затраты на присутствующее эмоциональное напряжение. Отдельная дифференциация этих потерь в проводимых исследованиях не проводилась. Основная цель заключалась в разработке метода оценки бесконтактного дистанционного текущего состояния спортсмена.

Полученный факт объясняется тем, что в сохранении рабочей позы проявляется одновременное сбалансированное напряжение мышц, как их синергистов, так и антагонистов. Кинематика в этом сбалансированном статическом напряжении определяется границами ее пульсации скорости и продолжительности ее протекания. Программа обработки этого материала разработана в ХГАФК и использовалась в ранее опубликованных работах [6; 7; 10]. В основе ее лежит: использование специальных семантических пространств с введенной в них единой мерой, обеспечивающих построение шкалы отношений сравниваемых показателей, отражающей динамику их протекания во время выполнения конкретной работы. Эти закономерности взаимоотношений текущего статического напряжения зависят от угла разгиба между биокинематическими звеньями, определяющих структуру построения локомоций и скорости их протекания.

Любой двигательный акт в обязательном порядке связан с наличием статического напряжения мышц антагонистов и синергистов, обеспечивающих рабочую позу выполняемого упражнения. Выполнение двигательного акта возможно при условии изменения напряжения между синергистами и антагонистами в определенном диапазоне, достаточном для полного осуществления кинематического его движения. В свою очередь, сам акт движения характеризуется скоростью перемещения биокинематических звеньев тела. Из сказанного следует, что структура построения необходимого признакового семантического пространства с введенной в нем единой мерой сопоставляемых характеристик состоит из равного статического мышечного напряжения антагонистов и синергистов, от их минимального значения до максимально возможного на текущий момент. Само движение осуществляется при некотором диапазоне напряжения между синергистами и антагонистами. Эти характеристики можно представить в декартовой прямоугольной системе координат, где оси будут отражать напряжение "антагонистов-синергистов". Естественно это единичный квадрат, т. к. напряжение изменяется от 0 до 1. Его диагональ отражает изменения равных усилий "антагонист-синергист", отношение которых на всей диагонали равно 1. Участок перемещения значения на координатных осях относительно его проек-
Ревенко, В., Пугач, Я., Друзь, В., Артемьев, В. (2019), "Современные методы контроля и оценки текущего функционально го состояния спортсменов в различных видах единоборств" Слобожанський науково-спортивний вісник, № 6(74), С. 5762, doi: 10.15391/snsv.2019-6.009 state of athletes in various types of martial arts", Slobozans kij naukovo-sportivnij visnik, No. 6(74), pp. 57-62, doi:10.15391/ snsv.2019-6.009 


\section{СЛОБОЖАНСЬКИЙ НАУКОВО-СПОРТИВНИЙ ВІСНИК}

ции на диагональ равен на $\sqrt{2}$ меньше, чем на диагонали.

Если относительно диагонали квадрата провести перпендикулярную прямую, на которой будет отражаться зона пульсации напряжения "антагонист-синергист", то при исключении параметра "время" будет построено необходимое фазовое семантическое пространство с единой мерой для всех упомянутых характеристик. Его особенность состоит в том, что текущее значение состояния одновременно находится на всех четырех шкалах и проецируется в обобщенный участок двух единичных квадратов, которые относительно друг к другу развернуто на $45^{\circ}$, что представлено на рисунке.

В силу теоремы распределения Архимеда, Кантора и теоремы случайности Дедекинда в обобщенной зоне построенного семантического пространства введена мера нормального закона распределения в долях сигмальных отклонений, что представлено на всех координатных осях. В обобщенной зоне в автоматизированном режиме вырисовывается участок интегральной кривой, заключенной в диапазоне $\pm \delta$ отклонения от зоны максимальной плотности частоты встречаемости взаимообусловленных наблюдаемых отклонений (рис.).

Эта задача сводится к определению производной от сложной функции, описывающей зависимость изменения развиваемой силы от режима изменения угла разгиба биокинематической пары, т. е. $\frac{d F}{d t}$, как сложной функции $\frac{d F}{d \varphi} \cdot \frac{d \varphi}{d t}$ или $\frac{d F}{d t}=\frac{d F}{d \varphi} \cdot \frac{d \varphi}{d t}$, где $\frac{d F}{d \varphi}$ определяет граничные условия, а $\frac{d \varphi}{d t}$ начальные условия осуществляемого движения.

Главная задача при формировании паспорта физического развития и оценке текущей функциональной готовности состояла в определении индивидуального характера их проявления. Установление факта расхода потенциального энергообеспечения по двум составляющим - на статическое напряжение и динамические усилия - обратило внимание на необходимость исследования характера проявления статического усилия от угла разгиба биокинематической пары, что определяется как первая производная.

Суть отмеченной закономерности состоит в регистрации величины оценки динамометрической становой силы при различном угловом расположении биокинематической пары "бедро-голень". Представляя результаты такого измерения в полярной системе координат, была получена зависимость, связывающая изменении угла разгиба ноги в коленном суставе на установленную величину градусов и наблюдаемую величину станового усилия. Как было установлено, эта зависимость состоит в том, что с увеличением угла разгиба, происходящего по закону арифметической прогрессии, соответствующее развиваемое статическое усилие протекает по геометрической прогрессии. В полярной системе координат эта зависимость выражена логарифмической спиралью, в которой радиус-вектор отражает величину развиваемого усилия в заданном положении биокинематической пары "бедро-голень".

Характерная особенность этой закономерности состоит в том, что не зависимо от утомления природа ее построения не изменяется. Кривизна спирали остается неизменной, но длина радиус-вектора, отражающего величину развиваемого станового статического напряжения, уменьшается. Длительность сохранения этого усилия сокращается. И та и другая величина снижаются по экс-

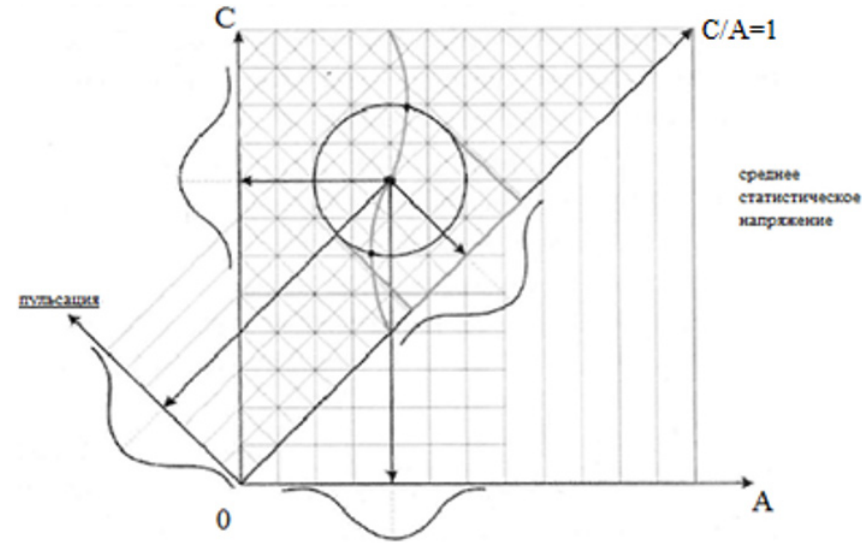

Рис. Закономерность движения общей точки показателя пульсации энергопотенциала в упорядоченном его представлении в признаковом семантическом пространстве при произвольном его проявлении в естественно протекаемом процессе поединка единоборца:

C - отражает величину синергетических усилий (C) в отношениях потенциальных возможностей со своим антагонистом $A$ в обеспечении равного статистического напряжения, которое представлено отношением C/A, равным во всех случаях 1, как коэффициент постоянных отношений статистического напряжекоэффициент постоянных отношений статистического напряжения (C/A), являющийся диагональю координатной системы, где координаты оси C; А. Ортогональная К диагонали C/A=1 пульсация относительно коэффициента $(C / A=1)$, которые составляют пространство, имеющие единое начало с пространством C; $A$ повернутое на угол $a=45^{\circ}$. Зона совместного пересечения этих пространств является областью, отражающей поведение общей точки, объединяющей взаимодействие всех 4-х параметров, которые порождают закономерную аналитическую связь их взаимообусловленных отношений.

поненциальной зависимости. Индивидуальные особенности проявления описанных закономерностей заключаются в том, что у каждого индивида наблюдается характерная для него кривизна логарифмической спирали.

Представленные аналитические зависимости позволяют не только отражать текущее состояние, но и дают возможность прогнозировать его развитие и определить доступную интенсивность выполняемой работы. Аналитический аппарат и соответствующие алгоритмы оценки текущего состояния с достаточной полнотой описаны в предшествующих работах [2; 7]. При полном объеме паспортных данных, составленных для каждого индивида, не представляет сложности на базе современных компьютерных систем обработки, видеорегистрирующей техники обеспечить текущий контроль выполнения двигательной деятельности спортсмена в период ведения им поединка.

В основе разработанного метода лежит восстановленный физический метод исследований, который получил название "коллективной фотографии". Суть метода заключается в многократном наслоении соразмерных фотографий лица мужчин одного возраста, в результате чего прорисовываются наиболее встречающиеся черты.

Метод позволяет без осуществления каких-либо расчетов получать непосредственно четко выраженную информацию о структуре строения наиболее выраженных характерных элементов лица.

Дороговизна метода привела Гальтона к разработке статистических методов исследований, которые с успехом приводили к нахождению модальных значений контролируемых параметров для нахождения их информационных показателей в исследуемой структуре строения объекта. Сам физический метод исследования был забыт 


\section{SLOBOZANS'KIJ NAUKOVO-SPORTIVNIJ VISNIK}

более чем на полтора столетия. Наличие современной видеорегистрирующей техники и теоретического обоснования построения признаковых семантических пространств с введенной в них единой мерой позволили восстановить метод физического моделирования. Данный метод имеет в современном его представлении высокую степень разрешимости сложных задач, недоступных для классических методов исследования [12; 13].

Наличие разработанного метода позволяет выполнять обратную задачу, состоящую в определении кривизны логарифмической спирали на основе видеорегистрирующих данных любого индивида, что представляет существенный интерес в планировании тактики ведения поединка с предстоящим противником. Кроме этого, данный метод контроля позволяет выделить и делать анализ наиболее утомительных и энергоемких затрат различных выполняемых локомоций спортсменов в период проведения поединка, что может быть визуализировано в любой удобной форме для дальнейшего анализа и построения тренировочного процесса. Объективность такого рода обработки полученных данных существенно определяется точностью выполняемых измерений в используемых семантических пространствах [8; 9; 14].

Таким образом, установленная взаимосвязь между характеристикой кинематики движения частей тела и мерой утомления позволили дифференцировать расход потенциального запаса энергии на динамическое усилие и на статическое напряжение мышц, направленное на сохранение рабочей позы спортсмена. По мере развивающегося утомления растет неточность выполняемых движений, замедляется скорость гашения инерции общего центра массы тела. Угловые перемещения между голенью и бедром увеличиваются. Такой эффект наблюдается не только при выполнении динамических усилий, направленных на перемещение тела, но и во время стойки ожидания спортсмена. При одинаковой длительности статического напряжения в стойке ожидания и такого же времени ак- тивного перемещения тела, возникающее утомление от "без движения" может быть не меньше, чем в активном перемещении тела. Это объясняется расходом энергии на рефлекс готовности к предстоящему действию и характеризуется напряженностью ожидания. Изменение точности движения и скорости кинематики гашения инерции движения позволяет также оценивать энергетические затраты на выполняемые приемы обоих участников поединка, что играет значительную роль в процессе построения тактики последующих действий. Данная методика динамического компьютерного моделирования разработана в ХГАФК на основе современной техники видеорегистрации движений и установленных закономерностей разделения энергозатрат на статическое напряжение рабочей позы и динамические усилия, обеспечивающие кинематику угловых перемещений между биозвеньями тела.

\section{Выводы / Дискуссия}

Наличие современных технических видеорегистрирующих средств, обеспечивающих необходимую скорость регистрации движущегося объекта, соответствующего компьютерного обеспечения и необходимого программного обеспечения позволили при использовании установленных закономерностей протекания биодинамических усилий и статического напряжения, наблюдаемых при выполнении соревновательных движений единоборцев разработать метод дистанционного бесконтактного контроля текущего состояния спортсменов. Этот метод открывает принципиально новые подходы в решении целого ряда задач, недоступные по своей сложности при использовании классических методов исследования двигательной деятельности спортсменов-единоборцев.

Дальнейшее развитие данного направления будет связано с более широкой его реализацией в практической деятельности при обеспечении подготовки спортсменов высокого класса.

Конфликт интересов. Авторы заявляют, что нет конфликта интересов, который может восприниматься как такой, что может нанести вред беспристрастности статьи. Источники финансирования. Эта статья не получила финансовой поддержки от государственной, общественной или коммерческой организации.

\section{Список ссылок}

1. Абдул Вахід Дшлад Нихад (2018), Організаційно-педагогічні основи відбору дітей для занять спортивною гімнастикою в автономній республіці Курдистан: дис. на здобуття наукового ступеня к. фіз. вих., ХДАФК, Харків, 201 с.

2. Ажиппо, А.Ю., Пугач, Я.И., Пятисоцкая, С.С., Жерновникова, Я.В., Друзь, В.А. (2015), Онтология теории построения и оценки уровня физического развития и физического состояния: монография, Харьков.

3. Анохин, П.К. (1973), Принципиальные вопросы общей теории функциональных систем. Принципы системной организации функций, Наука, Москва.

4. Бугаевский, К.А. (2018), "Анатомо-морфологические особенности костного таза у спортсменок юношеского возраста, занимающихся разными видами единоборств", Единоборства, № 2, С. 30-41.

5. Ван Син На (2012), Совершенствование техники выполнения соревновательных упражнений квалификационных спортсменов в пауэрлифтинге: дис. работа на соискание ученой степени к. физ. восп., ХГАФК, Харьков, 210 с.

6. Галашко, М.М. (2016), Використання морфо функціональних показників для прогнозування успішності спортивної діяльності армрестлерів: автореф. дис. на здобуття наук. ступеня канд. наук фіз. вих., Харків, 22 с.

7. Друзь, В.А., Омельченко, М.В., Омельченко, Д.А. (2015), "Основы техники спринтерского бега", Слобожанський науковоспортивний вісник, № 3(47), С. 41-45, doi: 10.15391/snsv. 2015-3.007.

8. Заде, Л. (1974), Основы нового подхода к анализу сложных систем процессов принятия решения, Знание, Москва.

9. Заде, Л. (1976), Понятие лингвистической переменной и его применение к принятию решения, Москва.

10. Пугач, Я.И. (2013), "Основные положения построения семантического пространства для упорядоченного представления результатов исследования", Материалы IX Международной научно-практической конференции "Бъдещего опросы отсвети на науката", София, Т. 39, С. 5-13.

11. Пугач, Я.И., Соколова, Т.Е., Ефременко, А.Н. (2017), "Использование современных технических достижений для разработки новых методов исследования адаптационных процессов с целью совершенствования технологий подготовки спортсменов высокой квалификации", Актуальные научные исследования в современном мире, № 12(32), Ч. 5, С. 45-53.

12. Самсонкин, В.Н., Друзь, В.А., Федорович, Е.С. (2010), Моделирование в самоорганизующих системах, Донецк.

Ревенко, В., Пугач, Я., Друзь, В., Артемьев, В. (2019), "Совре менные методы контроля и оценки текущего функционального состояния спортсменов в различных видах единоборств", Слобожанський науково-спортивний вісник, № 6(74), С. 5762, doi: 10.15391/snsv.2019-6.009 state of athletes in various types of martial arts", Slobozans kij naukovo-sportivnij visnik, No. 6(74), pp. 57-62, doi:10.15391/ snsv.2019-6.009 


\section{СЛОБОЖАНСЬКИЙ НАУКОВО-СПОРТИВНИЙ ВІСНИК}

13. Druz, V., Jermakow, S., Pugach, Ya., Shesterova, L., Zokow, W. \& Cieslicka M. (2016), "Kinematic characteristics of a sprinting and morphofunctional structures of it's providing", Jornal of Education, Health and sport, No. 6 (11), pp. 271-280.

14. Puhach, Ya., Druz, V., Yefremenko, A., Revenko, V., Galashko, M., Shutieiev, V., Nizhevskaya, T. \& Miroshnichenko, V. (2019), "Modern methods of monitoring and assessing the current status of athletes - combatants in real time", Slobozans'kij naukovo-sportivnij visnik, No. 3(71), pp. 54-60, doi: 10.15391/snsv.2019-3.009.

Стаття надійшла до редакції: 09.11.2019 р.

Опубліковано: 30.12 .2019 p.

Анотація. Володимир Ревенко, Ярославна Пугач, Валерій Друзь, Вадим Артем'єв. Сучасні методи контролю та оцінки поточного функціонального стану спортсменів у різних видах єдиноборств. Мета: розробка безконтактної системи контролю за поточним функціональним станом спортсмена у реальному масштабі часу. Матеріал і методи: аналіз науково-методичноі літератури щодо проблем досліджень, які виконуються; біомеханічний аналіз кінематичних і динамічних характеристик рухових дій спортсмена при виконанні змагальних вправ; методи математичної статистики; комп'ютерне математичне моделювання. Результати: розглянуто та проаналізовано існуючі методи оцінки функціонального стану організму в період тренувальної та змагальної діяльності спортсмена, на підставі чого визначено вимоги до побудови методу безконтактного контролю за функціональним станом спортсмена. Висновки: контроль за функціональним станом спортсменів-єдиноборців у даний час здійснюється сучасною апаратурою з високим ступенем точності і оперативністю обробки інформації, але тільки в контактному режимі, що виключає можливість оперативного контролю за поточним станом спортсмена в період проведення ним поєдинку. Дослідження біомеханіки руху кінематичних ланок кінцівок і статичної робочої пози за матеріалами відеозапису рухів спортсмена дозволили встановити залежність протікання динамічних зусиль, що визначають швидкість переміщення біокінематичних пар, що лягло в основу розробленого безконтактного методу оцінки міри стомленості спортсмена безпосередньо у період ведення поєдинку. Сучасна техніка відеореєстрації, комп'ютерного забезпечення і встановлених закономірностей кінематичних переміщень при різній статичній напрузі робочої пози дозволили досягти поставленої мети.

Ключові слава: спортсмени, єдиноборці, безконтактний контроль, статичне напруження, динамічні зусилля.

Abstract. Volodymyr Revenko, Yaroslavna Puhach, Valeriy Druz \& Vadym Artemiev. Modern methods of monitoring and evaluating the current functional state of athletes in various types of martial arts. Purpose: development of a contactless realtime monitoring system of the athlete's current functional state. Material \& Methods: analysis of scientific and methodological literature on the problems of ongoing research; biomechanical analysis of the kinematic and dynamic characteristics of the athlete's motor actions when performing competitive exercises; methods of mathematical statistics; computer mathematical modeling. Results: the existing methods for assessing the functional state of the body during the training and competitive activities of the athlete are reviewed and analyzed, on the basis of which the requirements for the construction of a method of contactless monitoring of the athlete's functional state are determined. Conclusions: the functional state of martial arts athletes is currently monitored by modern equipment with a high degree of accuracy and speed of information processing, but only in contact mode, which excludes the possibility of operational monitoring of the athlete's current state during the fight. The study of the biomechanics of the motion of the kinematic links of the limbs and the static working pose based on the materials of the video recording of the athlete's movements made it possible to establish the dependence of the flow of dynamic forces that determine the speed of movement of the biokinematic pairs, which formed the basis of the developed non-contact method for assessing the measure of athlete fatigue directly during the fight. Modern techniques of video recording, computer support and established patterns of kinematic movements at various static stresses of the working pose allowed us to achieve our goal.

Keywords: athletes, martial arts athletes, contactless control, static stress, dynamic efforts.

\section{References}

1. Abdul Vakhid Dshlad Nikhad (2018), Organizatsiyno-pedagogichni osnovi vidboru ditey dlya zanyat sportivnoyu gimnastikoyu v avtonomniy respublitsi Kurdistan: dis. na zdobuttya naukovogo stupenya $k$. fiz. vikh. [Organizational-pedagogical foundations for children in order to occupy sports gymnastics in the autonomous republic of Kurdistan: PhD dis.], KhSAPC, Kharkiv, 201 p. (in Ukr.)

2. Azhippo, A.Yu., Pugach, Ya.I., Pyatisotskaya, S.S., Zhernovnikova, Ya.V. \& Druz, V.A. (2015), Ontologiya teorii postroeniya i otsenki urovnya fizicheskogo razvitiya i fizicheskogo sostoyaniya: monografiya [Ontology of the theory of construction and assessment of the level of physical development and physical condition], Kharkiv. (in Russ.)

3. Anokhin, P.K. (1973), Printsipialnye voprosy obshchey teorii funktsionalnykh sistem. Printsipy sistemnoy organizatsii funktsiy [Fundamental questions of the general theory of functional systems. Principles of the systemic organization of functions], Nauka, Moscow. (in Russ.)

4. Bugaevskiy, K.A. (2018), "Anatomical and morphological features of the pelvis in young athletes involved in various types of martial arts", Yedinoborstva, No. 2, pp. 30-41. (in Russ.)

5. Van Sin $\mathrm{Na}$ (2012), Sovershenstvovanie tekhniki vypolneniya sorevnovatelnykh uprazhneniy kvalifikatsionnykh sportsmenov $v$ pauerliftinge: dis. rabota na soiskanie uchenoy stepeni k. fiz. vosp. [], KhSAPC, Kharkov, 210 p. (in Russ.)

6. Halashko, M.M. (2016), Vykorystannia morfo funktsionalnykh pokaznykiv dlia prohnozuvannia uspishnosti sportyvnoi diialnosti armrestleriv: avtoref. dys. na zdobuttia nauk. stupenia kand. nauk fiz. vykh., Kharkiv, 22 p. (in Ukr.)

7. Druz, V.A., Omelchenko, M.V. \& Omelchenko, D.A. (2015), "Fundamentals of sprinting techniques", Slobozans`kij naukovo-sportivnij visnik, No. 3(47), pp. 41-45, doi: 10.15391/snsv.2015-3.007. (in Russ.)

8.Zade, L. (1974), Osnovy novogo podkhoda kanalizu slozhnykh sistem protsessov prinyatiya resheniya [Fundamentals of a new approach to the analysis of complex systems of decision-making processes], Znanie, Moscow.

9.Zade, L. (1976), Ponyatie lingvisticheskoy peremennoy i ego primenenie $k$ prinyatiyu resheniya [The concept of a linguistic variable and its application to decision making], Moscow. (in Russ.)

10. Pugach, Ya.I. (2013), "Fundamentals of constructing a semantic space for an orderly presentation of research results", Materials of the IX International Scientific and Practical Conference "On the Future of Surveys for Science", Sofiya, P. 39, pp. 5-13. (in Russ.)

11. Pugach, Ya.I., Sokolova, T.Ye. \& Yefremenko, A.N. (2017), "The use of modern technological advances to develop new methods for studying adaptation processes in order to improve the technology of training highly qualified athletes", Aktualnye nauchnye issledovaniya $v$ sovremennom mire, No. 12(32), P. 5, pp. 45-53. (in Russ.)

12. Samsonkin, V.N., Druz, V.A. \& Fedorovich, Ye.S. (2010), Modelirovanie v samoorganizuyushchikh sistemakh [Modeling in selforganizing systems], Donetsk. (in Russ.)

13. Druz, V., Jermakow, S., Pugach, Ya., Shesterova, L., Zokow, W. \& Cieslicka M. (2016), "Kinematic characteristics of a sprinting and morphofunctional structures of it's providing", Jornal of Education, Health and sport, No. 6 (11), pp. 271-280.

14. Puhach, Ya., Druz, V., Yefremenko, A., Revenko, V., Galashko, M., Shutieiev, V., Nizhevskaya, T. \& Miroshnichenko, V. (2019), "Modern methods of monitoring and assessing the current status of athletes - combatants in real time", Slobozans'kij naukovo-sportivnij visnik, No. 3(71), pp. 54-60, doi: 10.15391/snsv.2019-3.009.

Ревенко, В., Пугач, Я., Друзь, В., Артемьев, В. (2019), "Современные методы контроля и оценки текущего функционального состояния спортсменов в различных видах единоборств", Слобожанський науково-спортивний вісник, № 6(74), С. 5762, doi: 10.15391/snsv.2019-6.009
Revenko, V., Puhach, Ya., Druz, V. \& Artemiev, V. (2019), "Modern methods of monitoring and evaluating the current functional state of athletes in various types of martial arts", Slobozans 'ki naukovo-sportivnij visnik, No. 6(74), pp. 57-62, doi:10.15391 snsv.2019-6.009 


\section{SLOBOZANS'KIJ NAUKOVO-SPORTIVNIJ VISNIK}

Received: 09.11.2019.

Published: 30.12 .2019

\section{Відомості про авторів / Information about the Authors}

Ревенко Володимир: к. пед. н., доцент; Харківська державна академія фізичної культури: вул. Клочківська 99, м. Харків, 61058, Україна.

Ревенко Владимир к. пед. н., доцент; Харьковская государственная академия физической культуры: ул. Клочковская 99, г. Харьков, 61058, Украина.

Volodymyr Revenko: PhD (Pedagogical Science), docent; Kharkiv State Academy of Physical Culture: Klochkivska str. 99, Kharkiv, 61058, Ukraine.

ORCID.ORG/0000-0002-3003-3538

E-mail: revphd@gmail.com

Пугач Ярославна Ігорівна: к. фіз. вих.; Харківська державна академія фізичної культури: вул. Клочківська 99, м. Харків, 61058, україна.

Пугач Ярославна Игоревна: к. физ. восп.; Харьковская государственная академия физической культуры: ул. Клочковская 99, г. Харьков, 61058, Украина.

Yaroslavna Puhach: PhD (Physical Education and Sport); Kharkiv State Academy of Physical Culture: Klochkivska str. 99, Kharkiv, 61058, Ukraine.

ORCID.ORG/0000-0001-5460-772X

E-mail: sanadruz@gmail.com

Друзь Валерій Анатолійович: д. б. н., професор; Харківська державна академія фізичної культури: вул Клочківська 99, м. Харків, 61058, Україна.

Друзь Валерий Анатольевич: д. б. н., профессор; Харьковская государственная академия физической культуры: ул. Клочковская 99, г. Харьков, 61058, Украина.

Valeriy Druz: Doctor of Science (Biology), Professor; Kharkiv State Academy of Physical Culture: Klochkivska 99, Kharkiv, 61058, Ukraine.

ORCID.ORG/0000-0002-4628-6791

E-mail: valeriidruz@gmail.com

Вадим Артем'єв: канд. психолог. наук, КЗ ДЮСШ №8, вул. Волонтерська, 4/6, 61093, м. Харків, Україна.

Вадим Артемьев: канд. психолог. наук, КУ ДЮСШ №8, ул. Волонтерская, 4/6, 61093, г. Харьков, Украина.

Vadym Artemiev: PhD (Psychological Sciences), Municipal institute "Complex children's and youth sports school №8 Kharkiv city council", st. Volunteer, 4/6, 61093, Kharkiv, Ukraine.

ORCID.ORG/0000-0002-1603-7401

E-mail: galina9767@gmail.com 


\title{
Побудова тренувального процесу юних гирьовичок 12-13 років протягом річного макроциклу 3 урахуванням специфічного біологічного циклу
}

\author{
Людмила Канунова \\ Віктор Джим
}

\author{
Харківська державна академія фізичної культури, \\ Харків, Україна
}

\begin{abstract}
Мета: розглянути питання щодо побудови тренувального процесу юних гирьовичок 12-13 років протягом річного макроциклу з урахуванням особливостей специфічного біологічного циклу.

Матеріал і методи: у роботі використано методи теоретичного аналізу і узагальнення наукової інформації, системний аналіз.

Результати: представлено сучасні підходи щодо особливостей побудови тренувального процесу юних гирьовичок 12-13 років; надано детальну структуру побудови річного макроциклу з урахуванням фаз ОМЦ.

Висновки: визначено, що у юних спортсменок, які займаються гирьовим спортом необхідно протягом річного макроциклу здійснювати розподіл навантажень відповідно до фаз ОМЦ, та переважно в базових та передзмагальних мезоциклах.
\end{abstract}

Ключові слова: юні спортсменки, специфічний біологічний цикл, фази ОМЦ, мікроцикли, мезоцикли.

\section{Вступ}

Сучасний спорт характеризується неухильним зростанням спортивних досягнень, що супроводжується збільшенням обсягів та інтенсивності тренувального навантаження. Такий підхід до тренувального процесу часто призводить до перенапруження регуляторних систем, виснаження адаптаційного резервутаскороченнятермінів виступів спортсменів, що не дає змоги досягнути високих спортивних результатів. Функціонування фізіологічних систем та адаптаційні процеси в організмі жінок відрізняються від таких у чоловіків. Це обумовлено однією з основних біологічних особливостей жіночого організму, пов'язаною з репродуктивною функцією - циклічністю функцій гіпоталамо-гіпофізарно-оваріально-адреналової системи. Низку досліджень (А. Р. Радзієвський, 1990; Ф. А. Іорданська, 2012; В. В. Мулик, 2001; 2016; Л. Я.-Г. Шахліна, 1995-2014), серед яких і закордонні (A. M. Burrows, S. R. Bird, 2005; S. B. Da Silva, 2006; A. J. Anderson, M. A. Babcock, 2008) присвячено впливові статевих гормонів у системі спортивної підготовки жінок. Фахівці встановили залежність прояву працездатності спортсменок різних спортивних спеціалізацій і реакцію їхного організму залежно від зміни концентрації статевих гормонів упродовж менструального циклу (МЦ) (В. В. Мулик, 2001; В. М. Платонов 2004; М. С. Пруднікова, 2009) $[4 ; 9 ; 10]$.

Зв'язок дослідження 3 науковими програмами, планами, темами. Наукове дослідження виконано за темою Зведеного плану науково-дослідної роботи Харківської державної академії фізичної культури на 2016-2020 рр. за темою "Методологічні і організаційнометодичні основи визначення індивідуальної норми фізичного стану людини" (номер державної реєстрації 0111U000192)

Мета дослідження: розглянути питання щодо побудови тренувального процесу юних гирьовичок 12-13 років протягом річного макроциклу з урахуванням особливостей специфічного біологічного циклу.

\section{Матеріал і методи дослідження}

Методи дослідження: відповідно до методологічного підходу у вирішенні проблеми і поставлених завдань програма досліджень включала комплекс методів дослідження: аналіз науково-методичної літератури, визначення спеціальної фізичної підготовленості за допомогою педагогічного тестування юних гирьовичок, педагогічне тестування за тренувальним процесом та методи математичної статистики

Організація дослідження: у даному дослідженні брали участь юні вихованці ДЮСШ № 16 та КЗ КДЮСШ № 8 м. Харкова. До експерименту були залучені 30 юних спортсменок-гирьовичок віком 12-13 років, які були розподілені на контрольну та експериментальну групи по 15 спортсменок у кожній із груп. Учасниці експерименту тренувались 3-4 рази на тиждень згідно розробленій методиці.

Експериментальні дослідження проводилися на навчально-тренувальній базі КЗ КДЮСШ № 8 та ДЮСШ № 16.

\section{Результати дослідження}

Спортивна підготовка юних спортсменок, які займаються гирьовим спортом, передбачає застосування засобів і методів, що впливають на розвиток таких фізичних якостей, як сила, силова витривалість та швидкісно-силова підготовка. Під впливом тренування в організмі спортсменки протікають певні зміни. У процесі адаптації до фізичного навантаження підвищується рівень фізичної працездатності та підготовленості спортсменки. Одним з проявів адаптації організму до силових проявів $€$ м'язова гіпертрофія. Однак для того, щоб зміни в тілі спортсменок мали позитивний характер, тренер повинен підібрати оптимальний режим тренування з урахуванням оваріально-менструального циклу та правильно підібраного відпочинку, правильно підібрати процедури відновлення, що сприяють швидшому зростанню спортивної майстерності. 


\section{SLOBOZANS'KIJ NAUKOVO-SPORTIVNIJ VISNIK}

У той час, на сьогодні, не має досліджень з приводу побудови річного макроциклу підготовки юних спортсменок, які займаються гирьовим спортом, з урахуванням оваріального менструального циклу, в якому враховуються використання навантажень у фази оваріального менструального циклу.

На початку досліджень юні спортсменки, які займаються гирьовим спортом, були розподілені на дві групи по 15 осіб в кожній. Спортсменки експериментальної групи тренувалися за розробленою експериментальною методикою, що передбачала в тренувальному процесі урахування навантажень у річному макроциклі фази оваріальноменструального циклу.

Спортивне тренування передбачає застосування засобів і методів підготовки, спрямованих на покращення рівня розвитку фізичних якостей. Тривалий вплив навантажень на організм викликає зміни у функціональному стан систем органів, внаслідок цього підвищується загальний рівень підготовленості та фізичної працездатності. Однак для того, щоб вплив занять спортом мав позитивний характер, тренер має підбирати адекватний рівень навантаження $з$ урахуванням фаз оваріального-менструального циклу, враховуючи індивідуальні особливості спортсменок [3-7].

Враховуючи рекомендації провідних спеціалістів в області побудови тренувального процесу підготовки спортсменок (В. М. Платонов, 2004; В. В. Мулик, 2017), обґрунтовано побудову двоциклової річної підготовки юних спортсменок, які займаються гирьовим спортом, з урахуванням фах ОМЦ протягом річного макроциклу.

У нашому дослідженні побудова річного макроциклу підготовки юних спортсменок базувалась на загальноприйнятій теорії періодизації (В. М. Платонов), яка передбачає поділ макроструктури на підготовчий змагальний та перехідний періоди та при появі менархе, нами було розроблено експериментальну методику побудови мезоциклів, з урахуванням фаз оваріальноменструального циклу.

Так, перший макроцикл, тривалістю 24 тижні (червень 2017 р. - листопад 2017 р.), мав у своїй структурі підготовчий період (червень - вересень 2017 р.), який складався з двох етапів загально- та спеціальнопідготовчого, в якому тренувальне навантаження поступово збільшувалося (табл. 1) тренувального процесу B загальнопідготовчому етапі (тривалість 12 тижнів) включав один втягувальний та два базових мезоцикли. Базовий мезоцикл мав експериментальний характер, де було врахувано фази оваріально-менструального циклу в тренувальному процесі, також завданнями мезоциклу передбачалося створення передумов для подальшої напруженої роботи, пов'язаної безпосередньо з нарощу-

ванням кількості підйомів гирь та використанням інших силових пристроїв.

Спеціально-підготовчий етап (тривалість 4 тижні) характеризується переважним використанням спеціалізованих вправ із застосуванням статичних, комбінованих та стато-динамічних режимів тренування, що дозволяють покращити в техніці підйому гирі юних спортсменок. Спеціально-підготовчий мезоцикл складався з втягувальних, ударних та відновних мікроциклів.

Структура змагального періоду, тривалістю 8 тижнів (жовтень - листопад 2017 р.) річного циклу, має передзмагальний та змагальний мезоцикли, включає втягувальний, підвідні та змагальний мікроцикли.

Другий макроцикл (тривалістю 24 тижні, грудень 2017 - квітень 2018 р.) за своїми завданнями та змістом $€$ органічним продовженням першого макроциклу, підготовчий період якого склав 12 тижнів (грудень 2017 лютий 2018)

Загально-підготовчий етап (тривалість 8 тижнів, грудень-січень) включав два мезоцикли: втягувальний та базовий. Базовий мезоцикл мав експериментальний характер, де було враховано фази оваріальноменструального циклу в тренувальному процесі, також завданнями мезоциклу передбачалося створення передумов для подальшої напруженої роботи, пов'язаної безпосередньо з нарощуванням силових та швидкісносилових якостей. Структура спеціально-підготовчого етапу, (тривалість 4 тижні), мала формуючий характер і включала "спеціально-підготовчий" мезоцикл.

Спеціально-підготовчий етап характеризується переважним використанням вузькоспеціалізованих вправ і використаннямстатичних, комбінованихтастато-динамічних режимів тренування, а також відпрацюванням вправи підняття гирі на кількість разів за хвилину. Спеціальнопідготовчий мезоцикл складався з відновного мікроциклу, втягуючого, ударного та відновного. Даний етап створював передумови для відновлення після базового мезоциклу.

Структура змагального періоду (тривалість 8 тижні) має формуючий характер. Об'єм навантаження знижується, особлива увага приділяється відпрацюванню технічних підйомів гирі на кількість разів. Задача даного періоду - досягнення найкращої пікової форми юних спортсменок. Структура змагального періоду річного циклу має передзмагальний та змагальний мезоцикли, включає підвідні та змагальний мікроцикли.

Перехідний період передбачає відновлення організму після тренувальної та змагальної діяльності.

Запропонований підхід до планування річного макроциклу підготовки для юних спортсменок-гирьовичок з урахуванням фаз оваріально-менструального циклу став основою програми побудови тренувального проце-

Таблиця 1

Структура річного здвоєного макроциклу юних спортсменок-гирьовичок 12-13 років з урахуванням біологічного циклу

\begin{tabular}{|c|c|c|c|c|c|c|c|c|c|c|c|c|}
\hline Макроцикли & \multicolumn{6}{|c|}{ I } & \multicolumn{6}{|c|}{ II } \\
\hline Періоди & \multicolumn{4}{|c|}{ Підготовчий } & \multirow{2}{*}{\multicolumn{2}{|c|}{$\begin{array}{c}\text { Змагальний } \\
\text { 3М }\end{array}$}} & \multicolumn{3}{|c|}{ Підготовчий } & \multicolumn{2}{|c|}{$3 \mathrm{M}$} & \multirow{2}{*}{$\begin{array}{l}\text { ПРХ } \\
\text { ВД }\end{array}$} \\
\hline Етапи & & 3-ח & & СП & & & & & СП & & & \\
\hline Мезоцикли & BT & Б-1 & Б-2 & СП & $\Pi 3$ & $3 \mathrm{M}$ & BT & Б-2 & СП & П3 & $3 \mathrm{M}$ & ПС \\
\hline Місяці & $\mathrm{VI}$ & VII & VIII & IX & $X$ & $\mathrm{XI}$ & XII & 1 & II & III & IV & V \\
\hline ОМЦ & Б & $X$ & $X$ & Б & $X$ & 5 & 5 & $X$ & E & $X$ & B & Б \\
\hline
\end{tabular}

Примітки. Мезоцикли: ВТ - втягувальний; Б-1 - базовий (загальна фізична підготовка); Б-2 - базовий (спеціальна фізична підготовка); СП - спеціально-підготовчий; ПЗ - передзмагальний; ЗМ - змагальний; ПС - поновлювально-підтримуючий. Б - без урахування фаз оваріально-менструального циклу; X - з урахуванням фаз оваріально-менструального циклу.

Канунова, Л., Джим, В. (2019), "Побудова тренувального процесу юних гирьовичок $12-13$ років протягом річного макроциклу з урахуванням специфічного біологічного циклу", Слобожанський науково-спортивний вісник, № 6(74), С. 63-67, doi: $10.15391 /$ snsv.2019-6.010
Kanunova, L. \& Dzhym, V. (2019), "The construction of the training process of young weight lifters $12-13$ years old during one-year macrocycle, taking into account the specific biological cycle", Slobozans"kij naukovo-sportivnij visnik, No. 6(74), pp. ,63-67 doi:10.15391/snsv.2019-6.010 


\section{СЛОБОЖАНСЬКИЙ НАУКОВО-СПОРТИВНИЙ ВІСНИК}

су юних спортсменок, які займаються гирьовим спортом, експериментальної групи.

Результати експерименту були наступними.

Тестування рівня спеціальної фізичної підготовленості у спортсменок 12-13 років, які займаються гирьовим спортом, проходило із застосуванням спеціальних та спеціально-підготовчих вправ: станова тяга 324 кг гирею; присідання з 24 кг гирею; ривок гирі 8 кг за 10 хв та вису на поперечині (табл. 2).

Таблиця 2

Середні показники результатів спеціальної фізичної підготовленості юних спортсменок 12-13 років, що займаються гирьовим спортом, з урахування фаз ОМЦ на початку річного макроциклу $\left(\mathrm{n}_{1}=\mathrm{n}_{2}=15\right)$

\begin{tabular}{|c|c|c|c|c|}
\hline Показники & KГ & EГ & $T$ & $\boldsymbol{P}$ \\
\hline
\end{tabular}

Ривок гирі 8 кг за 10 хв, рази $15,4 \pm 2,29 \quad 16,1 \pm 2,40 \quad 0,21>0,05$

Присідання з 24 кг гирею, рази

$12,5 \pm 2,57 \quad 12,1 \pm 2,57 \quad 0,11>0,05$

Станова тяга з 24 кг гирею, рази

$35,2 \pm 2,05 \quad 34,8 \pm 2,12 \quad 0,13>0,05$

Виси на поперечині, с

$36,4 \pm 0,96 \quad 35,2 \pm 0,85 \quad 0,94>0,05$

Аналіз показників прояву спеціальної фізичної підготовленості у спортсменок 12-13 років на початку річного макроциклу показав, що розходження результатів були недостовірні: у ривку гирі 8 кг (контрольна - 15,4 разів, експериментальна - 16, 1 разів; $\mathrm{P}>0,05)$; присідання із 24 кг гирею (відповідно - 12,5 разів, 12,1 разів; $\mathrm{P}>0,05$ ); станова тяга 324 кг гирею (контрольна - 35,2 разів, експериментальна 34,8 разів; $\mathrm{P}>0,05)$; висі на поперечині (відповідно - 36,4 с, 35,2 с; Р>0,05) (табл. 2).

Таблиця 3

Середні показники приросту результатів спеціальної фізичної підготовленості юних спортсменок 12-13 років, що займаються гирьовим спортом, з урахування фаз ОМЦ наприкінці річного макроциклу $\left(\mathrm{n}_{1}=\mathrm{n}_{2}=15\right)$

\begin{tabular}{|c|c|c|c|c|}
\hline Показники & & $\mathrm{E} \Gamma$ & $T$ & $\boldsymbol{P}$ \\
\hline
\end{tabular}

Ривок гирі 8 кг за 10 хв

$22,1 \pm 2,36 \quad 30,2 \pm 2,89 \quad 2,17<0,05$

Присідання з 24 кг гирею, рази

$18,7 \pm 2,20 \quad 26,6 \pm 2,46 \quad 2,37<0,05$

Станова тяга з 24 кг гирею, рази

$41,2 \pm 2,25 \quad 47,8 \pm 1,90 \quad 2,24<0,05$

Виси на поперечині, с

$38,2 \pm 0,66 \quad 40,2 \pm 0,56 \quad 2,31<0,05$

Протягом проведеного дослідження у кінці річного макроциклу у спортсменок 12-13 років, які займаються гирьовим спортом, вірогідною була різниця між показниками: у ривку гирі 8 кг (контрольна - 22,1 разів, експериментальна - 30,2 разів ( $\mathrm{t}=2,17 ; \mathrm{P}<0,05)$; присідання із 24 кг гирею (відповідно - 18,7 разів, 26,6 разів $(\mathrm{t}=2,37 ; \mathrm{P}<0,05)$; станова тяга з 24 кг гирею (контрольна - 41,2 разів, експериментальна 47,8 разів ( $t=2,24 ; \mathrm{P}<0,05)$; висі на поперечині (відповідно - 38,2 c, 40,2 c (t=2,31; P<0,05) (табл. 3).

\section{Висновки / Дискусія}

Аналіз наукової літератури підтвердив, що дослідження в галузі гирьового спорту в основному мали особливий характер. За останні роки вченими були проведені дослідження щодо змісту і методики тренувального процесу юних спортсменок-гирьовичьок 12-13 років з різними методами удосконалення рухових навичок і силових якостей (Ю.В.Верхошанский [1]), планування тренувального процесу протягом річного макроциклу спортсменок 12-15 років (В. М. Платонов [8-9]) та впливу тренувального процесу юних спортсменок-гирьовичок 12-13 років на прояви фізичних якостей (Н. С. Іполитов). Однак не було вивчено впливу на працездатність юних спортсменок-гирьовичок $12-13$ років фізичних навантажень на першому етапі навчання у багаторічній підготовці, що і спонукало нас розробити побудову тренувального процесу юних гирьовичок 12-13 років протягом річного макроциклу 3 урахуванням оваріально-менструальних фаз.

На сьогодні існує цілий ряд наукових досліджень, в яких розглядаються питання щодо особливостей побудови тренувального процесу спортсменок на основі урахування працездатності в різні періоди (фази) специфічного біологічного циклу. Основоположними $€$ роботи А. Р. Радзієвського, Ю. Т. Похоленчука, Н.В.Свечникової, Б. П. Пангелова, Т. А. Лози, С. К. Фоміна, А. Я. Квале, Ю. А. Коропа, Л. Я.-Г. Шахліної, які визначали функціональний станспортсменокпротягом специфічного біологічного циклу. У меншій мірі досліджено питання побудови тренувального процесу юних спортсменок, особливо підчас становлення специфічного біологічного циклу.

Експериментальна програма тренувань, яка була розроблена для спортсменок-гирьовичок 12-13 років з урахуванням фаз оваріально-менструального циклу, передбачала здвоєну структуру річної підготовки, яка включала два макроцикли: перший, що мав підготовчий (загальнопідготовчий, спеціально-підготовчий етапи) та змагальний (змагальний етап) періоди; другий - 3 наявністю підготовчого (загально-підготовчий i спеціальнопідготовчий етапи) та змагального (змагальний етап) і перехідного (відновний етап) періодів.

у якості засобів тренувань використовувалися змагальні та змагально-допоміжні вправи, які застосовувалися диференційовано у залежності від фаз оваріальноменструального циклу згідно розробленої програми тренувань протягом річного макроциклу.

Впровадження методики тренувального процесу юних гирьовичок 12-13 років протягом річного макроциклу з урахуванням фаз оваріально-менструального циклу сприяло достовірному підвищенню показників змагальних та змагально-допоміжних вправ у експериментальній групі.

Протягом проведеного дослідження в кінці річного макроциклу у спортсменок 12-13 років, які займаються гирьовим спортом, вірогідною була і різниця між показниками: у ривку гирі 8 кг (t=2,17; $\mathrm{P}<0,05)$; присіданні із 24 кг гирею ( $\mathrm{t}=2,37 ; \mathrm{P}<0,05)$; станова тяга з 24 кг гирею $(\mathrm{t}=2,24$; $\mathrm{P}<0,05)$; висі на поперечині $(\mathrm{t}=2,31 ; \mathrm{P}<0,05)$.

Проведене дослідження підтвердило результати інших авторів [1; 2] щодо необхідності врахування впливу 


\section{SLOBOZANS'KIJ NAUKOVO-SPORTIVNIJ VISNIK}

тренувань на фізичні показники спортсменок 12-13 років на етапі початкової підготовки. Також були розширені дані вітчизняних [4-5; 8; 9; 11] і зарубіжних авторів [16-22] з питань підвищення рівня найбільш значущих показників фізичних якостей спортсменок, які займаються гирьовим спортом.

Перспектива подальших досліджень передбачає визначення побудови тренувального процесу юних гирьовичок 12-13 років в окремих мезоциклах, які ураховують фази ОМЦ.

Конфлікт інтересів. Автори заявляють, що немає конфлікту інтересів, який може сприйматися таким, що може завдати шкоди неупередженості статті. Джерела фінансування. Ця стаття не отримала фінансової підтримки від державної, громадської або комерційної організацій.

\section{Список посилань}

1. Верхошанский, Ю.В. (2013), Основы специальной силовой подготовки в спорте, Советский спорт, Москва.

2. Джим, В.Ю. (2013), "Сравнительный анализ техники рывковых упражнений в тяжелой атлетике и гиревом спорте", Педагогіка, психологія та медико-біологічні проблеми фізичного виховання і спорту, № 11, С. 10-16.

3. Иорданская, Ф.А. (2012), Мужчина и женщина в спорте высших достижений: Проблемы полового диморфизма, Сов. спорт, Москва

4. Мулик, В.В. (2001), Система многолетнего спортивного совершенствования в усложненных условиях сопряжения основных сторон подготовленности спортсменов (на материале лыжного спорта): автореф. дис. на соискание уч. степени д-ра наук по физ. восп. и спорту: спец. 24.00.01 "Олимпийский и профессиональный спорт", Київ.

5. Мулик, В.В. (2016), "Сучасні аспекти побудови тренувального процесу спортсменок", Слобожанський науково-спортивний вісник, № 5(55), С. 57-62.

6. Новиков, В.П. (1990), "Характеристика развития силы у школьников 7-10 лет", Возрастные особенности физиологических систем детей и подростков, Москва, С. 203-204

7. Олешко, В.Г. (2011), Підготовка спортсменів у силових видах спорту : навч. посіб. для вузів, ДІА, Київ.

8. Платонов, В.Н. (2004), Система подготовки спортсменов в олимпийском спорте. Общая теория и ее практические приложения, Олимп. лит, Киев.

9. Платонов, В.Н. (2015), Система подготовки спортсменов в олимпийском спорте. Общая теория и ее практические приложения : учеб-ник для тренеров: в 2 кн., Олимп. лит., Киев, Кн. 2

10. Прудникова, М.С., Мулик, В.В. (2009), "Влияние физических нагрузок на функциональное состояние и личностные качества юных велосипедисток 12-15 лет в период становления ОМЦ", Слобожанський науково-спортивний вісник, №3, С. 164-167.

11. Ровний, А.С. (2001), Формування системи сенсорного контролю точних рухів спортсменів: автореф. дис. на здобуття наук. ступеня д-ра наук з фіз.. виховання і спорту: спец. 24.00.02. "Фізична культура, фізичне виховання різних груп населення", Київ, $40 \mathrm{c}$.

12. Шахлина, Л.Г. (1995), Медико-биологические основы управления процессом спортивной тренировки женщин: Автореф. дис. д-ра мед. наук, Киев, 32 с.

13. Шахлина, Л.Г. (1999), "Проблемы полового диморфизма в спорте высших достижений", Теория и практика физ. культуры, № 6, C. $51-55$

14. Шахлина, Л.Г. (2000), "Женщины и спорт на рубеже третьего тысячелетия", Наука в олимпийском спорте, № 4, С. 10-22.

15. Шейко, Б.И. (2008), "Методика планирования для начинающих пауэрлифтеров", Мир силы, № 4, С. 28-29.

16. Casazza, G.A., Jacobs, K.A., Suh, S. et al. (2004), "Menstrual cycle phase and oral contraceptive effects on triglyceride mobilization during exercise", J. Appl. Physiol, Vol. 97, pp. 302-309.

17. Horton, T.J. Miller, E.K. \& Bourret, K. (2006), "No effect of menstrual cycle phase on glycerol or palmitate kinetics during 90 min of moderate exercise", J. Appl. Physiol, Vol. 100, pp. 917-925.

18. Jacobs, K.A., Cassaza, G.A., Suh, S. et al. (2005), "Fatty acid re-esterification but not oxidation is increased by oral contraceptive use in women", J. Appl. Physiol, Vol. 98, pp. 1720-1731.

19. Janse de Jonge, X.A. (2003), "Effects of the menstrual cycle on exercise performance", Sports Med, Vol. 33, pp. 833-851.

20. Kenney, L.W., Wilmore, J.H. \& Costiil, D.L. (2012), Physiology of sport and exercise, Human Kinetics, Champaign.

21. Nimmo, M.A. (2009), "The female athletes", Olympic text-book of science in sport, Maughan, R.J. (ed.), Blackwell Sci. Publ., pp. 382-400.

22. Wilmore, J.H. \& Costill, D.L. (2005), Physiology of sport and exercise.

Стаття надійшла до редакції: 10.11.2019 p.

Опубліковано: 30.12 .2019 p.

Аннотация. Людмила Канунова, Виктор Джим. Построение тренировочного процесса юных гиревичек 12-13 лет в течение годичного макроцикла с учетом специфического биологического цикла. Цель: рассмотреть вопрос построения тренировочного процесса юных гиревичек 12-13 лет в течение годичного макроцикла с учетом особенностей специфического биологического цикла. Материал и методы: в работе использованы методы теоретического анализа и обобщения научной информации, системный анализ. Результаты: представлены современные подходы построения тренировочного процесса юных гиревичек 12-13 лет, представлена детальная структура построения годичного макроцикла с учетом фаз ОМЦ. Выводы: определено, что у юных спортсменок, занимающихся гиревым спортом, необходимо в течение годичного макроцикла осуществлять детальное распределение нагрузок в соответствии с фазами ОМЦ, и необходимо учитывать нагрузки в базовых и соревновательных мезоциклах.

Ключевые слова: юные спортсменки, специфический биологический цикл, фазы ОМЦ, микроциклы, мезоцикль.

Abstract. Liudmyla Kanunova \& Viktor Dzhym. The construction of the training process of young weight lifters 12-13 years old during a one-year macrocycle, taking into account the specific biological cycle. Purpose: to consider the question of building the training process of young weight lifters of 12-13 years during a one-year macrocycle, taking into account the peculiarities of a specific biological cycle. Material \& Methods: the methods of theoretical analysis and generalization of scientific information, system analysis are used in the work. Results: modern approaches to constructing the training process of young weight lifters of 12-13 years are presented, a detailed structure of the construction of a one-year macrocycle taking into account the CMC phases is presented. Conclusions: it was determined that for young athletes involved in kettlebell lifting, it is necessary to carry out a detailed load distribution in accordance with the phases of the CMC during a one-year macrocycle, and it is necessary to take into account loads in basic and competitive mesocycles.

Канунова, Л., Джим, В. (2019), "Побудова тренувального процесу юних гирьовичок 12-13 років протягом річного макроциклу з урахуванням специфічного біологічного циклу", Слобожанський науково-спортивний вісник, № 6(74), С. 63-67, doi: $10.15391 /$ snsv.2019-6.010
Kanunova, L. \& Dzhym, V. (2019), "The construction of the training process of young weight lifters $12-13$ years old during a one-year macrocycle, taking into account the specific biological cycle", Slobozans'kij naukovo-sportivnij visnik, No. 6(74), pp ,63-67 doi:10.15391/snsv.2019-6.010 


\section{СЛОБОЖАНСЬКИЙ НАУКОВО-СПОРТИВНИЙ ВІСНИК}

Keywords: young athletes, specific biological cycle, CMC phases, microcycles, mesocycles.

\section{References}

1. Verkhoshanskiy, Yu.V. (2013), Osnovy spetsialnoy silovoy podgotovki v sporte [Fundamentals of Special Strength Training in Sports], Sovetskiy sport, Moscow. (in Russ.)

2. Dzhim, V.Yu. (2013), "Comparative analysis of jerking exercises in weightlifting and kettlebell lifting", Pedagogika, psikhologiya ta mediko-biologichni problemi fizichnogo vikhovannya i sportu, No. 11, pp. 10-16. (in Russ.)

3. Iordanskaya, F.A. (2012), Muzhchina i zhenshchina v sporte vysshikh dostizheniy: Problemy polovogo dimorfizma [Man and woman in the sport of higher achievements: Problems of sexual dimorphism], Sov. sport, Moscow. (in Russ.)

4. Mulik, V.V. (2001), Sistema mnogoletnego sportivnogo sovershenstvovaniya v uslozhnennykh usloviyakh sopryazheniya osnovnykh storon podgotovlennosti sportsmenov (na materiale lyzhnogo sporta): avtoref. dis. na soiskanie uch. stepeni d-ra nauk po fiz. vosp. i sportu: spets. 24.00.01 "Olimpiyskiy i professionalnyy sport» [The system of many years of sports improvement in complicated conditions of pairing the main aspects of athletes' fitness (based on skiing): DS thesis abstract], Kiiiv. (in Russ.)

5. Mulyk, V.V. (2016), "Modern Aspects of Building a Training Process for Female Athletes", Slobozans'kij naukovo-sportivnij visnik, No. 5(55), pp. 57-62. (in Ukr.)

6. Novikov, V.P. (1990), "Characteristic of the development of strength in schoolchildren 7-10 years old", Vozrastnye osobennosti fiziologicheskikh sistem detey i podrostkov, Moscow, pp. 203-204. (in Russ.)

7. Oleshko, V.H. (2011), Pidhotovka sportsmeniv u sylovykh vydakh sportu : navch. posib. dlia vuziv [Training Athletes in Power Sports], DIA, Kyiv. (in Ukr.)

8. Platonov, V.N. (2004), Sistema podgotovki sportsmenov v olimpiyskom sporte. Obshchaya teoriya i ee prakticheskie prilozheniya [The system of training athletes in Olympic sports. General theory and its practical applications], Olimp. lit., Kiev, Book 1. (in Russ.)

9. Platonov, V.N. (2015), Sistema podgotovki sportsmenov v olimpiyskom sporte. Obshchaya teoriya i ee prakticheskie prilozheniya [The system of training athletes in Olympic sports. General theory and its practical applications], Olimp. lit., Kiev, Book 2. (in Russ.)

10. Prudnikova, M.S. \& Mulik, V.V. (2009), "The influence of physical activity on the functional state and personal qualities of young cyclists 12-15 years old during the formation of the CMC", Slobozans 'kij naukovo-sportivnij visnik, No. 3, pp. 164-167. (in Russ.)

11. Rovnyi, A.S. (2001), Formuvannia systemy sensornoho kontroliu tochnykh rukhiv sportsmeniv: avtoref. dys. na zdobuttia nauk. stupenia d-ra nauk z fiz.. vykhovannia i sportu: spets. 24.00.02. „Fizychna kultura, fizychne vykhovannia riznykh hrup naselennia” [Formation of a system of sensory control of precise movements of athletes: DS thesis abstract], Kyiv, 40 p. (in Ukr.)

12. Shakhlina, L.G. (1995), Mediko-biologicheskie osnovy upravleniya protsessom sportivnoy trenirovki zhenshchin: Avtoref. dis. d-ra med. nauk [Biomedical foundations of managing the process of women's sports training: DS thesis abstract], Kiev, 32 p. (in Russ.)

13. Shakhlina, L.G. (1999), "Problems of Sexual Dimorphism in the Sport of Higher Achievements", Teoriya i praktika fiz. kultury, No. 6 , pp. 51-55. (in Russ.)

14. Shakhlina, L.G. (2000), "Women and Sport on the Frontier of the Third Millennium", Nauka v olimpiyskom spopte, No. 4, pp. 10-22. (in Russ.)

15. Sheyko, B.I. (2008), "Planning Techniques for Beginner Powerlifters", Mir sily, No. 4, pp. 28-29. (in Russ.)

16. Casazza, G.A., Jacobs, K.A., Suh, S. et al. (2004), "Menstrual cycle phase and oral contraceptive effects on triglyceride mobilization during exercise", J. Appl. Physiol, Vol. 97, pp. 302-309.

17. Horton, T.J. Miller, E.K. \& Bourret, K. (2006), "No effect of menstrual cycle phase on glycerol or palmitate kinetics during 90 min of moderate exercise", J. Appl. Physiol, Vol. 100, pp. 917-925.

18. Jacobs, K.A., Cassaza, G.A., Suh, S. et al. (2005), "Fatty acid re-esterification but not oxidation is increased by oral contraceptive use in women", J. Appl. Physiol, Vol. 98, pp. 1720-1731.

19. Janse de Jonge, X.A. (2003), "Effects of the menstrual cycle on exercise performance", Sports Med, Vol. 33, pp. 833-851.

20. Kenney, L.W., Wilmore, J.H. \& Costiil, D.L. (2012), Physiology of sport and exercise, Human Kinetics, Champaign.

21. Nimmo, M.A. (2009), "The female athletes", Olympic text-book of science in sport, Maughan, R.J. (ed.), Blackwell Sci. Publ., pp. 382-400.

22. Wilmore, J.H. \& Costill, D.L. (2005), Physiology of sport and exercise.

Received: 10.11 .2019

Published: 30.12 .2019 .

\section{Відомості про авторів / Information about the Authors}

Канунова Людмила Володимирівна: Харківська державна академія фізичної культури: вул. Клочківська 99, м. Харків, 61058, україна.

Канунова Людмила Владимировна: Харьковская государственная академия физической культуры: ул. Клочковская 99 , г. Харьков, 61058, Украина.

Liudmyla Kanunova: Kharkiv State Academy of Physical Culture: st. Klochkivska, 99, Kharkov, 61058, Ukraine.

ORCID.ORG/0000-0003-3545-5438

E-mail: Ikanunova17@gmail.com

Джим Віктор Юрійович: к. фіз. вих.; Харківська державна академія фізичної культури: вул. Клочківська 99, м. Харків, 61058, україна.

Джим Виктор Юрьевич: к. физ. вых.; Харьковская государственная академия физической культуры: ул. Клочковская 99, г. Харьков, 61058, Украина.

Viktor Dzhym: PhD (Physical Education and Sport); Kharkiv State Academy of Physical Culture: st. Klochkivska, 99, Kharkov, 61058, Ukraine.

ORCID.ORG/0000-0002-4869-4844

E-mail: djimvictor@gmail.com 


\section{Шановні колеги! \\ Запрошуємо Вас подавати свої наукові статті до публікування в науковому фаховому виданні \\ Харківської державної академії фізичної культури}

"Слобожанський науково-спортивний вісник"

При підготовці статей просимо Вас дотримуватися наступних вимог:

Текст статті (без анотацій та списку літератури) обсягом 8 і більше сторінок формату A4 у редакторі WORD 2003 (y форматі *.doc) або rtf.

Шрифт - Times New Roman 14, нормальний, без переносів, абзаци - 1,25, вирівнювання за шириною.

Поля сторінки: справа, зліва, зверху та знизу 20 мм, орієнтація сторінки - книжкова, міжрядковий інтервал - 1,5 (в таблицях - 1). Мова статті - українська, російська, англійська

\section{СТРУКТУРА СТАТTI}

Тематичний рубрикатор удк.

Назва статті (до 10 слів). Назва статті повинна відображати зміст і мету цієї статті.

Ім'я та Прізвища авторів.

Місце роботи або навчання (назва установи чи організації, місто, країна).

Анотація. Анотація повинна відображувати зміст статті; мати структуру: Мета: ..., Матеріал і методи: ..., Результати: ..., Висновки: .... Якщо мова статті не українська - анотація українською мовою подається у розширеному вигляді (1800 знаків з пробілами). Подається трьома мовами (укр., англ., рос.)

Ключові слова: 5-8 слів, які характеризують досліджувану проблему

Вступ. Вступ описує, що автор сподівається досягти, та чітко означає досліджувану проблему. Повинен узагальнювати відповідні дослідження для забезпечення контексту і пояснювати, які дослідження інших авторів, якщо такі є, оскаржуються або вимагають продовження. Наприкінці Вступу вказується мету дослідження.

Матеріал і методи дослідження. Розділ статті, що повинен описувати експеримент, гіпотези, загальний план експерименту або методику. Повинно бути сформульовано план, відповідний для відповідей на питання. Представлено достатньо інформації, щоб відтворити дослідження (характер контингенту досліджуваних, методи). Вказати, які в статті дотримуються процедури. Розташувати їх в порядку значимості. Якщо такі методи є новими, вони повинні мати докладні пояснення. Вказати наявність вибірки. Описати належним чином обладнання та матеріали. Для статей медичного характеру потрібно вказати відповідні стандарти про дотримання етики медичних досліджень (за участю людини або тварин).

Результати дослідження. Автор повинен пояснити, яких відкриттів він досяг в дослідженні. Вони повинні бути зрозуміло згруповані і мати логічну послідовність. Представлений належний аналіз отриманих результатів дослідження; статистичні дані.

Висновки / Дискусія. У даному розділі подається інтерпретація результатів дослідження; як результати співвідносяться з очікуваннями і більш раннім дослідженням; стаття підтримує або спростовує попередні теорії. Пояснюється, як дослідження вплинуло на прогрес наукових знань. Наприкінці розділу вказуються Перспективи подальших досліджень у даному напрямку.

Список посилань подається у двох варіантах:

1. Кирилицею (не менше 10, з яких не менш 5 - іноземних) повинен налічувати достатню кількість сучасних (за останні 5 років) джерел за проблемою дослідження, до якого необхідно включати наукові статті з українських та зарубіжних фахових наукових журналів. Відомості про них повинні відповідати вимогам Гарвардського стилю. Текст статті обов'язково повинен містити посилання на використані літературні джерела.

2. Латиницею (References) оформлюється за Гарвадською системою (BSI). Рекомендації щодо оформлення можна подивитися за посиланням.

Наприкінці статті обов'язково вкажіть для кожного автора (українською, англійською та російською мовами): прізвище, ім'я та по батькові (повністю) із зазначенням учених ступенів і вчених звань, місце роботи (офіційну назву та поштову адресу установи чи організації); ORCID; e-mail.

Статті просимо надсилати у встановлений термін в електронному вигляді за адресою:

E-mail: hdafk.edu@gmail.com. Тема листа та ім'я файлу статті: Прізвище автора_Стаття.

тел. редакції (057) 705-21-02.

\section{Сайт журналу: http://journals.uran.ua/index.php/1991-0177}

Сайт англомовної версії журналу

"Slobozhanskyi Herald of Science and Sport": http://journals.uran.ua/sport_herald

Вихід журналу:

№1 - лютий, №2 - квітень, №3 - червень, №4 - серпень, №5 - жовтень, №6 - грудень

Терміни подання статей

№1 - до 20 січня; №2 - до 20 березня; №3 - до 20 травня;

№4 - до 20 липня; №5 - до 20 вересня; №6 - до 20 листопада 


\section{СЛОБОЖАНСЬКИЙ НАУКОВО-СПОРТИВНИЙ ВІСНИК}

За достовірність представлених результатів відповідають автори

Редактор:

В. М. Каштанова

Технічний редактор:

Н. Ю. Канцедал

Видання Харківської державної

академії фізичної культури

Харківська державна академія фізичної культури

Україна, 61058, Харків, 58,вул.Клочківська,99

(0572) 705-21-02

hdafk.edu@gmail.com 